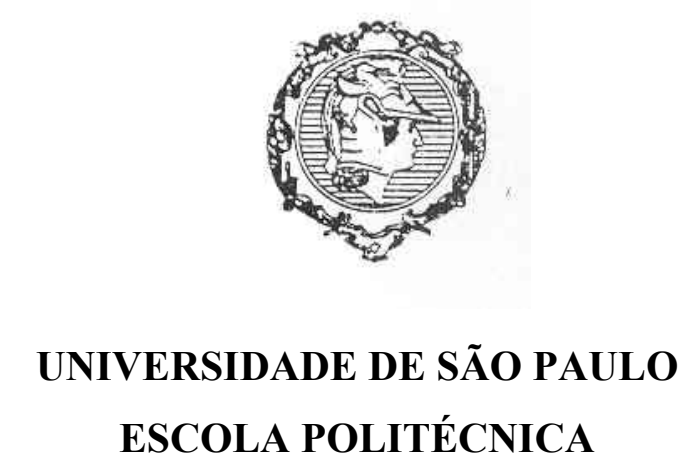

Claudia Bastos do Nascimento

\title{
DETERIORAÇÃO DE FORRO EM ESTUQUE REFORÇADO COM RIPAS VEGETAIS: \\ O Caso "Vila Penteado" - FAUUSP
}

Dissertação apresentada à Escola Politécnica da Universidade de São Paulo para obtenção do título de Mestre em Engenharia 


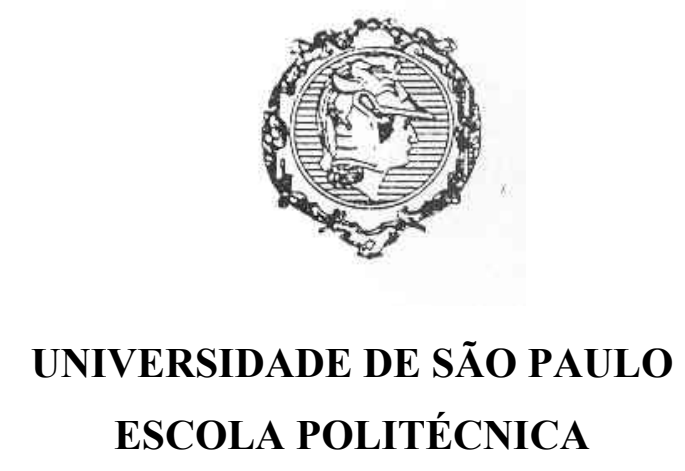

Claudia Bastos do Nascimento

\title{
DETERIORAÇÃO DE FORRO EM ESTUQUE REFORÇADO COM RIPAS VEGETAIS: O Caso "Vila Penteado" - FAUUSP
}

\author{
Dissertação apresentada à Escola \\ Politécnica da Universidade de São \\ Paulo para obtenção do título de Mestre \\ em Engenharia \\ Área de Concentração: \\ Construção Civil \\ Orientador: \\ Prof $^{\mathrm{a}}$. Dr ${ }^{\mathrm{a}}$. Maria Alba Cincotto
}


FICHA CATALOGRÁFICA

Nascimento, Claudia Bastos do

Deterioração de forro em estuque reforçado com ripas vegetais: o caso

"Vila Penteado" - FAUUSP. São Paulo, 2002.

$244 \mathrm{p}$.

Dissertação (Mestrado) - Escola Politécnica da Universidade de São Paulo. Departamento de Engenharia de Construção Civil.

1. forro em estuque 2. argamassa de revestimento I. Universidade de São

Paulo. Escola Politécnica. Departamento de Engenharia de Construção Civil 
À minha família, em especial, minha avó Jandyra, meus pais, Ivon e Gilda, Giuseppe e Luigi. 


\section{AGRADECIMENTOS}

A Deus pela sua eterna companhia em meu desafio, fazendo brotar a esperança frente às dificuldades e por presentear-me com a capacidade intelectual, o discernimento e a humildade necessários para finalizar este trabalho.

À minha família, Ivon, Gilda, Jandyra, Ivon Júnior, Carlos Alberto, Patrícia, Fernando e Pedro que mesmo distantes acreditaram, me incentivaram e apoiaram.

Ao Giuseppe e, especialmente, ao Luigi que me dividiram com este trabalho sem cobranças e reclamações.

À minha orientadora Profa. Dra. Maria Alba Cincotto, que aceitou o desafio de orientar esta pesquisa e deu sua contribuição muito importante para sua finalização.

À Faculdade de Arquitetura e Urbanismo por disponibilizar a edificação para o estudo proposto, em especial ao Prof. Dr. Júlio Katinsky.

Aos funcionários da Poli com os quais convivi e que me auxiliaram durante a pesquisa, em especial, Mário, Dorval, Reginaldo, Fátima, Alcione, Engrácia, Paulo, Leonor e Fátima. Aos técnicos dos laboratórios que caracterizaram as amostras de argamassa, deste estudo. Aos amigos que conquistei ao longo desta jornada e que exemplificaram o real conceito da multidisciplinaridade, em especial, Mirian, Valdecir, Fabiano, Maria Beatriz, Osório e Evaristo. 
Aos amigos e colegas que fiz na Poli e no IPT, pelo incentivo e apoio em muitos dos momentos difíceis, em especial, Bonin, Jussara, Yêda, Artemária, Rubiane, Maristela, Vanessa, Claudia, Carlos Henrique, Márcia, Ernan, Tango, Luiz, Bilesky, Josias Marcelino, Jozias Cruz, Marli, Leopoldo, Elizabeth, Anaí, Malva, Maria Marta e Rosely.

A todos os professores da EPUSP e UFRGS que contribuíram para minha formação profissional, em especial aos professores Dario e Campagnolo que me encaminharam a pesquisa tecnológica voltada para a preservação do patrimônio histórico e cultural do país. Agradeço com carinho também ao professor Vanderley, pelas discussões sobre a pesquisa.

À Coordenação de Aperfeiçoamento de Pessoal de Nível Superior - CAPES e à Fundação de Apoio à Pesquisa do Estado de São Paulo - FAPESP, pelo financiamento parcial desta pesquisa por meio da bolsa de estudos.

Ao Instituto de Pesquisas Tecnológicas - IPT, por dispor de seus laboratórios e permitir que eu dedicasse parte do meu período de trabalho para o desenvolvimento desta pesquisa. A todos que direta ou indiretamente colaboraram na execução deste trabalho.

Muito obrigada, 


\section{SUMÁRIO}

LISTA DE FIGURAS..

LISTA DE TABELAS.

LISTA DE ABREVEIATURAS E SIGLAS.

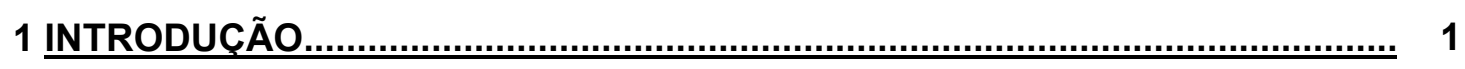

1.1 Justificativa do tema............................................................................... 1

1.2 Atividades de conservação e restauro de edificações

históricas................................................................................................ 4

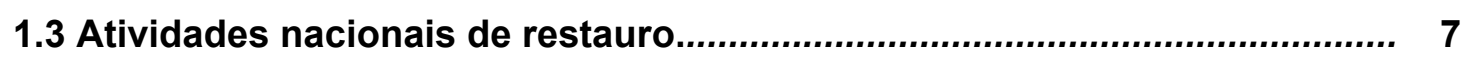

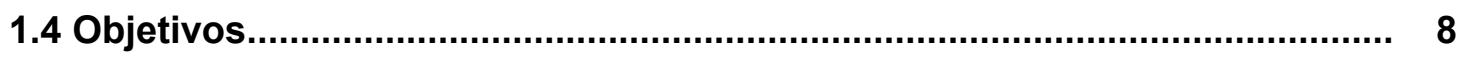

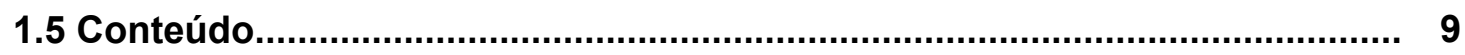

2 PRESERVAC̨ÃO DO PATRIMÔNIO HISTÓRICO EDIFICADO ............................. 12

2.1 Resumo histórico............................................................................. 14

2.2 Principais instituições internacionais e nacionais..................................... 18

2.3 Importância da multidisciplinaridade..................................................... 22

2.4 A abordagem científica na atividade de restauro................................... 23

2.5 Princípios que regem as intervenções...................................................... 25

3 EXPERIÊNCIAS DE RESTAURO - ABORDAGEM PARTICULAR EM

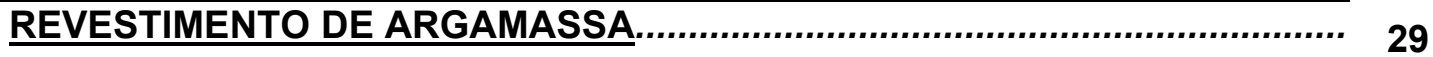

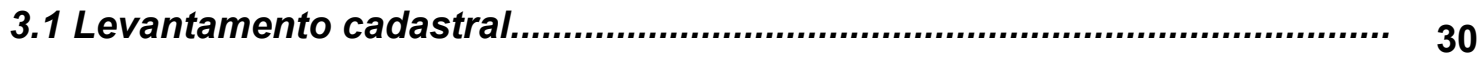

3.1.1 Ensaio in-loco - resistência de aderência em revestimentos................... 34

3.2 Levantamento bibliográfico das técnicas construtivas............................. 35

3.3 Estudo dos materiais empregados - análise de argamassa em

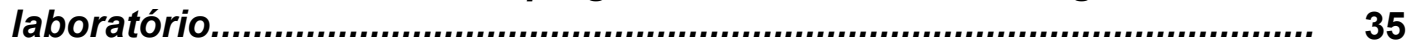

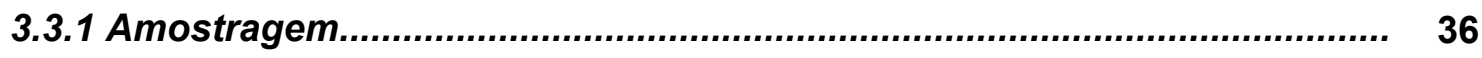

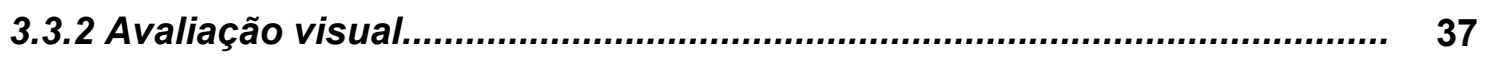

3.3.3 Análise por difração de raios X (DRX) ............................................... 37 
3.3.4 Reconstituição da proporção aglomerante: agregado por análise química.

3.3.5 Termogravimetria -TG.

3.3.6 Análise granulométrica do agregado.

3.3.7 Análise petrográfica.

3.3.8 Observações da microestrutura por microscopia eletrônica de varredura (MEV)

3.3.9 Porosimetria por intrusão de mercúrio. 48

3.3.10 Isolamento e identificação de fungos. 49

3.3.11 Outras técnicas. 52

3.4 Métodos de intervenção 53

3.4.1 Argamassas de restauro. 56

4 METODOLOGIA EMPREGADA NO ESTUDO DO FORRO EM ESTUQUE DA EDIFICAÇÃO VILA PENTEADO .....................................................................

4.1 Levantamento cadastral (informações históricas e técnicas sobre a edificação)

4.2 Levantamento bibliográfico. 59

4.3 Estudo dos materiais empregados. 60

4.3.1 Amostragem. 60

4.3.1.1 Identificação das amostras. 64

4.3.2 Procedimento de coleta.

4.3.3 Seleção das amostras a serem analisadas. 69

4.3.4 Resistência de aderência do revestimento. 71

4.3.5 Análise da argamassa em laboratório. 72

4.3.5.1 Análise por difração de raios $X(D R X)$ 72

4.3.5.2 Reconstituição da proporção aglomerante : agregado por análise química.

4.3.5.3 Análise pétrográfica.

4.3.5.4 Observações da microestrutura por microscopia eletrônica de varredura (MEV)

4.3.5.5 Porosimetria por intrusão de mercúrio. 75

4.3.5.6 Isolamento e identificação de fungos. 75 
4.3.6 Sanidade biológica das ripas de juçara.

4.3.7 Simulação do sistema de restauro do forro em estuque da edificação Vila Penteado.

4.3.8 Avaliação do desempenho do sistema de restauro

5. LEVANTAMENTO CADASTRAL DO FORRO EM ESTUQUE DA

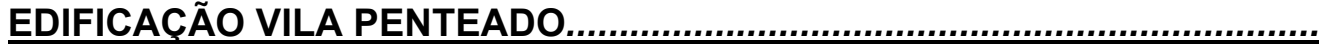

5.1 Técnica construtiva de forro em estuque - levantamento bibliográfico.

5.1.1 Histórico da técnica de estuque. 84

5.1.2 Descrição da técnica de estuque

5.2 Descrição do sistema de forro em estuque da edificação Vila Penteado.

5.3 Registro cronológico de vistorias, recomendações de recuperação e intervenções no forro.

5.4 Estado de conservação do forro em estuque.

5.4.1 Avaliação quanto ao estado de fissuração

5.4.2 Avaliação quanto à presença de umidade. 101

5.4.3 Avaliação quanto aos indícios de biodeterioração

6 RESULTADOS E DISCUSSÕES

6.1 Anomalias observadas durante a amostragem.

6.1.1 Pavimento térreo

6.1.2 Pavimento superior

6.2 Análise de caracterização e avaliação microestrutural da argamassa em laboratório.

6.2.1 Análise por difração de raios $X(D R X)$

6.2.2 Análise química

6.2.3 Análise petrográfica.

6.2.3.1 Descrição das fases.

6.2.4 Microscopia eletrônica de varredura (MEV).

6.2.5 Porosidade das amostras

6.2.6 Considerações sobre a caracterização e a avaliação microestrutural das amostras de argamassa.

6.3 Análise da biodeterioração. 
6.3.1 Isolamento e identificação de fungos na argamassa.

6.3.2 Observação da superfície da argamassa em microscópio estéreoscópico.

6.3.3 Sanidade biológica das ripas de juçara.

6.3.4 Considerações sobre a biodeterioração e seu mecanismo.

6.4 Ensaio de desempenho do sistema de restauro proposto

6.4.1 Avaliação visual.

6.4.2 Resistência de aderência do sistema de restauro.

Anexo A Breve levantamento cadastral da edificação Vila Penteado.

Anexo B Eventos sobre a preservação e restauração do patrimônio histórico mundial edificado e princípios definidos durante os mesmos.

Anexo C Estudos de casos de restaurações no patrimônio histórico e arquitetônico e métodos de investigação empregados no estudo de argamassa.

Anexo D Registro fotográfico da vistoria preliminar do forro da Edificação Vila Penteado em 1997.

Anexo E Registro fotográfico da mapoteca (T10) após queda parcial do forro em 1994.

Anexo F Proposta de fixação do forro em estuque precedente a este estudo.

Anexo G Resultados das análises de DRX. 


\section{Lista de Figuras}

Figura 1.1 - Vista da edificação Vila Penteado (Postal datado de 20.04.1919, obtido na feira de antiguidades do MASP).

Figura 1.2 - Família do Conde Antônio Álvares Penteado, no começo do século. Ao centro sentado o Conde; da esquerda para a direita, seus filhos Stella e Armando, Condessa Ana, seu filho Silvio, o genro Caio Prado, as filhas Antonieta e Eglantina. (UNIVERSIDADE DE SÃO PAULO, 1976).

Figura 2.1 - Atividades de restauro de edificações e áreas afins do conhecimento.

Figura 3.1 - Fluxograma de atuação para a resolução de problemas patológicos. (LICHTENSTEIN, 1986).

Figura 3.2 - (a) Cristais de carbonatos de cálcio formados na argamassa de cal; (b) Morfologia das partículas carbonáticas (LUXÁN; DORREGO, 1996)

Figura 3.3 - (a) Cristais de C-S-H no interior do poro; (b) Maior magnificação do C-S-H presente na micrografia (a); e (c) DRX da amostra de argamassa analisada (LUXÁN; DORREGO, 1996).

Figura 3.4 - Microorganismos identificados nas amostras de argamassa empregada no Memorial Victoria - região (1) estruturas fibrilares e região (2) estrutura granular (SARKAR et al., 1994).

Figura 3.5 - Forma dos poros da argamassa, característicos da lixiviação do aglomerante (SARKAR et al., 1994).

Figura 3.6 - Etapas da análise microbiológica efetuada para identificação dos fungos, nos revestimentos com bolor (SHIRAKAWA et al., 1995).

Figura 4.1 - Etapas do estudo forro em estuque da edificação Vila Penteado.

Figura 4.2 - Distribuição dos pontos de coleta de amostra - Pavimento Térreo.

Figura 4.3 - Distribuição dos pontos de coleta de amostra - Pavimento Superior.

Figura 4.4 - Diagrama de bloco do procedimento de coleta de amostras A.

Figura 4.5 - Diagrama de bloco do procedimento de coleta de amostras B.

Figura 4.6 - Diagrama de bloco do procedimento de coleta de amostras C.

Figura 4.7 - Local de coleta da amostra S19A. Região bastante deteriorada embaixo da viga metálica. (a) Vista pelo sótão; (b) Vista pelo hall superior (S19), 
ante-sala da secretaria, após corte da placa de madeirite (em vermelho) com serra-copo de $50 \mathrm{~mm}$ de diâmetro - vide Figura 4.8.

Figura 4.8 - Procedimento de coleta da amostra S19A; (a) corte com serra-copo; (b) detalhe da ripa de juçara bastante deteriorada e sem nenhum resquício de argamassa evidenciando nenhuma aderência entre esses materiais.

Figura 4.9 - Coleta de amostras retiradas na camada superior do forro em estuque acesso pelo sótão (S20B). (a) corte furadeira manual; (b) detalhe da ripa de juçara considerada íntegra nessa região. A facilidade para destacamento da argamassa denotou a baixa aderência às ripas de juçara.

Figura 4.10 - Seleção de amostras e análises realizadas.

Figura 4.11 - Preparação para o ensaio de resistência de aderência do revestimento no cômodo T10 (mapoteca); (a) aspecto geral do revestimento cortado com serra-copo de $50 \mathrm{~mm}$ de diâmetro; (b) detalhe da desagregação da argamassa, inviabilizando a realização do ensaio.

Figura 4.12 - à esquerda: corpos-de-prova para a determinação da aderência do sistema de restauro à argamassa original; à direita:. corpos-de-prova para a determinação da aderência do sistema de restauro aos materiais originais considerando $50 \%$ de interface argamassa nova/juçara e $50 \%$ argamassa nova/argamassa original.

Figura 4.13 - Corpos-de-prova ensaiados para a determinação da resistência à tração direta da argamassa original.

Figura 5.1 - Ferramentas (SEGURADO, 1936) e equipamento (LEITÃO, 1896) utilizados para a preparação da argamassa: (a) ganchetas; (b) ferro de corte; (c) "amassador mecânico de Roger".

Figura 5.2 - Croqui visto em planta e em corte do madeiramento de suporte da tela sugerido por BORGES (1972).

Figura 5.3 - Artefato para aplicação da argamassa no forro em estuque (BORGES, 1972). Este artefato é denominado por SEGURADO (1936) de esparável.

Figura 5.4 - Moldes utilizados para execução de: (a) molduras; (b) cimalhas; (c) pinturas (SEGURADO, 1936).

Figura 5.5 - Representação esquemática do sistema de forro em estuque: (a) pavimento térreo; (b) pavimento superior. 
Figura 6.1 - Vista geral da região do forro (aproximadamente $2 \mathrm{~m}^{2}$ ) que desabou do cômodo T10 (mapoteca).

Figura 6.2 - Detalhe do madeiramento de suporte do piso superior e da juçara expostos pelo desabamento do forro com indícios da biodeterioração por diversos microorganismos e pela presença de cupins na mapoteca (cômodo T10): (a) observa-se frutificações e micélio de fungos no madeiramento de suporte do assoalho do piso superior; (b) detalhe de quatro ripas de juçara com galerias no seu interior.

Figura 6.3 - Utilização de madeira alternativa à juçara na região das amostras S10A e S10B.

Figura 6.4 - Estado das ripas de juçara: diferentes comportamentos quando submetidas ao corte com serra manual e formão; (a) amostra de juçara de difícil corte; (b) desfibramento da ripa de juçara devido ao corte.

Figura 6.5 - Face inferior do forro, após a abertura na placa de compensado, sem indícios de biodeterioração no revestimento.

Figura 6.6 - Fotomicrografia da amostra T04A, não deteriorada. Aspecto geral da amostra, com polarizadores descruzados, observando-se: pasta (p), em preto; vazios (v) em cinza; agregado predominantemente quartzoso (qz) em branco; e torrões de argila $(\mathrm{t})$ com forma arredondada, em preto com borda acinzentada. Aumento utilizado: $22 \mathrm{x}$.

Figura 6.7 - Fotomicrografia da amostra S19A, não deteriorada. Aspectos observados na amostra com polarizadores descruzados: pasta (p) em preto; vazios (v) em cinza; agregado predominantemente quartzoso (qz), em branco e feldspato levemente alterado (f), rajado. Aumentos utilizados: fotomicrografias (a) e (b) $22 \mathrm{x}$ e fotomicrografia (c) $87 \mathrm{x}$.

Figura 6.8 - Fotomicrografia da amostra T10D, deteriorada (amostra do entorno da região do forro em estuque colapsada). Aspectos observados na amostra com polarizadores descruzados: pasta (p), em preto; vazios (v), em cinza; agregado predominantemente quartzoso (qz), em branco e feldspato alterado (f), rajado. Aumentos utilizados: fotomicrografia (a) $7 \mathrm{x}$; e fotomicrografias (b) e (c) $22 \mathrm{x}$.

Figura 6.9 - Fotomicrografia da amostra S19A, deteriorada: (a) com polarizadores descruzados e (b) com polarizadores cruzados, o que possibilitou 
verificar a carbonatação restrita e localizada na pasta. Aumento utilizado: $22 \mathrm{x}$.

Figura 6.10 - Fotomicrografias da amostra T04A, não deteriorada. (a) aspecto de um grão de quartzo do agregado envolto pela pasta; (b) detalhe de fissura no grão de quartzo.

Figura 6.11 - Fotomicrografias da amostra S19C, não deteriorada. (a) Aspecto geral da amostra observado pela microscopia eletrônica de varredura, evidenciando a porosidade; (b) aspecto da área assinalada na fotomicrografia a; (c) detalhe de um grão de feldspato, da pasta ao seu redor e dos vazios de interface; (d) detalhe de um grão de mica totalmente solto da pasta.

Figura 6.12 - Porosidade acumulada.

Figura 6.13 - Análise comparativa dos poros.

Figura 6.14 - Histograma de porosidade mensurável por intrusão de mercúrio.

Figura 6.15 - Porosidade das amostras T04A e S19C: comparação entre dados mensuráveis pela porosimetria por intrusão de mercúrio e mensuráveis por técnicas auxiliares.

Figura 6.16 - Colônia de fungos obtida pelo microcultivo, onde predomina o Trichoderma sp.

Figura 6.17 - Imagem da amostra T10D em microscópio estereoscópico evidenciando impressões deixadas por fungos filamentosos.

Figura 6.18 - Imagens em microscópio óptico da lâmina delgada preparada da amostra T10Dj: (a) células intensamente perfuradas por ataque de fungos; (b) detalhe de hifa de fungo no interior de uma célula.

Figura 6.19 - Imagem em microscópio óptico da lâmina delgada preparada da amostra S19Aj, evidenciando o ataque dos fungos nas células, com hifas rompendo as paredes e se interligando.

Figura 6.20 - Corpo-de-prova submetido aos ciclos térmicos após a simulação do sistema de restauro: (a) camada de argamassa do forro original sob as ripas de juçara; (b) camada de argamassa nova sobre as ripas de juçara.

Figura 6.21 - Tipo de ruptura do ensaio de resistência de aderência. À esquerda: condição $\mathrm{C}$; à direita: condição $\mathrm{D}$.

Figura 6.22 - Seção transversal do forro após intervenção. 


\section{Lista de Tabelas}

Tabela 2-1 Temas e assuntos abordados pela BS 7913 (BSI,1998)

Tabela 3-1 Espécies químicas e suas respectivas faixas de temperatura de transformação (ZAMPIERI, 1993)

Tabela 3-2 Microorganismos colonizadores e orientação respectiva das fachadas (PERRICHET (1987) apud SHIRAKAWA (1999))

Tabela 4-1 Características distintivas entre regiões sãs e deterioradas

Tabela 4-2 Identificação e localização das amostras

Tabela 4-3 Ângulos de ocorrência dos picos dos espectros dos minerais comuns em argamassa

Tabela 5-1 Dimensões dos sarrafos sugeridas por BORGES (1972).

Tabela 6-1 Resultados da análise química (base não volátil)

Tabela 6-2 Resultados da análise petrográfica

Tabela 6-3 Resultados da porosidade das amostras coletadas em regiões sãs

Tabela 6-4 Resultados da identificação dos fungos presentes na argamassa 


\section{Lista de abreviaturas e siglas}

ABNT - Associação Brasileira de Normas Técnicas

ABRACOR - Associação Brasileira de Conservadores e Restauradores de Bens Culturais

ANTAC - Associação Brasileira de Tecnologia do Ambiente Construído

ASTM - American Standard Test Methods

ATD - análise térmica diferencial

BS - British Standard

CAEC - Comissão de Atividades Extra-curriculares da FAU

CECOR - Centro de Conservação e Restauração de Bens Culturais Móveis, Escola de Belas Artes

CECR - Curso de Especialização em Conservação/Restauração de Bens Culturais Móveis

CECRE - Curso de Especialização em Conservação e Restauração de Monumentos e Conjuntos Históricos

$\mathrm{CH}$ I - cal hidratada tipo I

$\mathrm{CH}$ III - cal hidratada tipo III

CNPq - Conselho Nacional para Pesquisa e Desenvolvimento

CONPRESP - Conselho Municipal de Preservação do Patrimônio Histórico, Cultural e Ambiental da Cidade de São Paulo

CONDEPHAAT - Conselho de Defesa do Patrimônio Histórico, Artístico,

Arqueológico e Turístico do Estado de São Paulo

CPC - Comissão do Patrimônio Cultural

CPG - Comissão de Pós-Graduação

CPqDCC - Centro de Pesquisa do Departamento de Construção Civil

C-S-H - silicato de cálcio hidratado

DRX - difração por raios-X

DTA - Análise térmica diferencial

EDS - microanálise de energia dispersiva 
EPUSP - Escola Politécnica da Universidade de São Paulo

e-MAT - Revista eletrônica de ciência e tecnologia de materiais de construção civil

FAUUSP - Faculdade de Arquitetura e Urbanismo da Universidade de São Paulo

FIHUAT - Federation Internationale pour l'Habitation, l'Urbanisme et l'Amenagement

de Territoires

FUNDUSP - Fundação da Universidade de São Paulo

GFAU - Grêmio estudantil da Faculdade de Arquitetura e Urbanismo

ICB - Instituto de Ciências Biomédicas

ICCROM - Centro Internacional de Estudos para a Conservação e Restauração dos Bens

Culturais

ICOM - Conselho Internacional dos Museus

ICOMOS - Conselho Internacional dos Monumentos e Sítios

IEPHA - Instituto Estadual do Patrimônio Histórico e Artístico.

IFHP - International Federation for Housing and Planning

IFROA - Instituto de Formação de Restauradores de Obras de Arte

INEPAC - Instituto Estadual do Patrimônio Cultural

IPAC - Instituto do Patrimônio Artístico e Cultural

IPHAE - Instituto de Patrimônio Histórico e Artístico do Estado

IPHAN - Instituto do Patrimônio Histórico e Artístico Nacional.

IPT - Instituto de Pesquisas Tecnológicas do Estado de São Paulo

IVWSR - Internationaler Verband fur Wohnungswesen Stadtebau und Raumordnung.

JCPDS - Joint Committee on Powder Diffraction Standards

MASP - Museu de Arte de São Paulo

MEV - microscopia eletrônica de varredura

NBR - Norma Brasileira

PNC - Plano Nacional da Cultura para Proteção, Salva-guarda e Valorização do

Patrimônio Histórico e Artístico;

SPHAN - Secretaria do Patrimônio Histórico e Artístico Nacional.

$\mathrm{TG}$ - termogravimetria

UFC - unidades formadoras de colônia

UNESCO - Organização das Nações Unidas para a Educação, Ciência e Cultura 


\title{
DETERIORAÇÃO DE FORRO EM ESTUQUE REFORÇADO COM RIPAS VEGETAIS: O Caso "Vila Penteado" - FAUUSP
}

\author{
Claudia Bastos do Nascimento
}

\begin{abstract}
RESUMO
Esta pesquisa apresenta uma investigação sobre a argamassa de cal e as ripas de juçara (Euterpe eudulis), materiais empregados no forro em estuque da edificação Vila Penteado, seguindo as diretrizes propostas pelas Instituições de preservação de edificações e de monumentos de valor histórico e artístico. Esta edificação foi tombada pelo CONDEPHAAT - Conselho de Defesa do Patrimônio Histórico, Artístico, Arqueológico e Turístico do Estado de São Paulo e pelo CONPRESP - Conselho Municipal de Preservação do Patrimônio Histórico, Cultural e Ambiental da Cidade de São Paulo.

Um conjunto amplo de técnicas foi utilizado para caracterizar a composição e a microestrutura da argamassa original, bem como o estado de conservação dos materiais. Os resultados destas análises serviram de subsídio para a elaboração de uma proposta de reconstituição parcial do forro. O desempenho desta proposta foi avaliado em laboratório, sendo o corpo-de-prova mantido por 30 dias em câmara de carbonatação após a preparação e a aplicação da argamassa. A avaliação da compatibilidade térmica dos materiais originais e novos, quando submetidos a ciclos de aquecimento e resfriamento, foi utilizada como indicador de desempenho do método de restauro. Além disso, foram realizadas avaliações da resistência de aderência do sistema, conforme especificado na NBR 13528 (ABNT, 1995).

Estes resultados mostraram que a argamassa original pode manter sua funcionalidade ao longo dos anos, desde que se opte pela técnica de intervenção correta e que a fragilidade do sistema de forro em estuque está nas ripas de suporte. Esta avaliação permitiu a elaboração de uma proposta de restauro para o sistema de forro da edificação Vila Penteado.
\end{abstract}




\title{
DETERIORATION OF VEGETABLE FIBRE REINFORCED STUCCO WORK CEILING: The "Vila Penteado" - FAUUSP case
}

\author{
Claudia Bastos do Nascimento
}

\begin{abstract}
This research presents an investigation on the base-lime mortar and Juçara (palm tree Euterpe eudulis) laths which were the materials found in the stucco ceiling of the building, Vila Penteado. The guidelines followed in this study were those set fourth by the Institutions of maintenance for buildings and monuments with historical and artistic value. This building was declared a heritage by CONDEPHAAT - The Council for the Defense of Historical, Artistic, Archeological and Tourist Patrimony of the State of São Paulo and by CONPRESP - The Council for the Preservation of the Historical, Cultural and Environmental Patrimony of Sao Paulo City.

A broad set of techniques was used to characterize the composition and the microstructure of the primitive mortar, as well as the condition of the materials. The results of these analyzes were useful in proposing a partial reconstitution of the ceiling. The performance of this proposal was evaluated in laboratory conditions by keeping the specimen in a carbonation chamber for thirty (30) days after application, to accelerate curing. The thermal compatibility and adhesion strength resistance of the primitive and new materials were tested after subjecting them to heating and quenching cycles, and the results were used as indicators of the proposed restoration method's performance.

These results showed that the primitive mortar can remain serviceable for many years as long as the correct intervention technique is employed, and the fragility of the ceiling system is in the supporting laths. This evaluation allowed for the elaboration of a proposal for restoring the ceiling system of the Vila Penteado building.
\end{abstract}




\section{INTRODUÇÃO}

\subsection{Justificativa do tema}

Esta pesquisa tem como objeto de estudo o forro em estuque da edificação Vila Penteado, sito à rua Maranhão $n^{\circ} 88$, bairro Higienópolis, São Paulo, que atualmente abriga a pós-graduação da Faculdade de Arquitetura e Urbanismo da Universidade de São Paulo. Esta edificação (Figura 1.1) representa um marco do período de transição sócio-econômica da cidade e também um dos poucos exemplares do estilo Art Nouveau ${ }^{1.1}$ remanescente do início do século XX.

O projeto da edificação foi encomendado ao arquiteto sueco Carlos Ekman, pelo Conde Antônio Álvares Penteado que, por volta de 1890, deixara junto com a família a Fazenda Palmares em Santa Cruz das Palmeiras para viver na capital paulista. O Conde, com espírito empreendedor, investiu inicialmente na tecelagem e posteriormente no comércio, no ensino e nas artes. A Figura 1.2 retrata a família Álvares Penteado.

${ }^{1.1}$ Art Nouveau - recebeu outras designações que refletem fontes variadas e contextos específicos: modern style, na Inglaterra; secessionstil, na Áustria; jungendstil, na Alemanha; stile floreale ou liberty, na Itália; modernismo, na Espanha. Significou a ruptura com o academismo e o ecletismo do século XIX. Expressou uma tendência essencialmente decorativa, que destacou o valor ornamental da linha curva de origem vegetal (Bélgica, França) ou geométrica (Escócia e Áustria), desdobrada em formas sinuosas, ondulantes e invariavelmente assimétricas (LAROUSSE CULTURAL, 1998). 


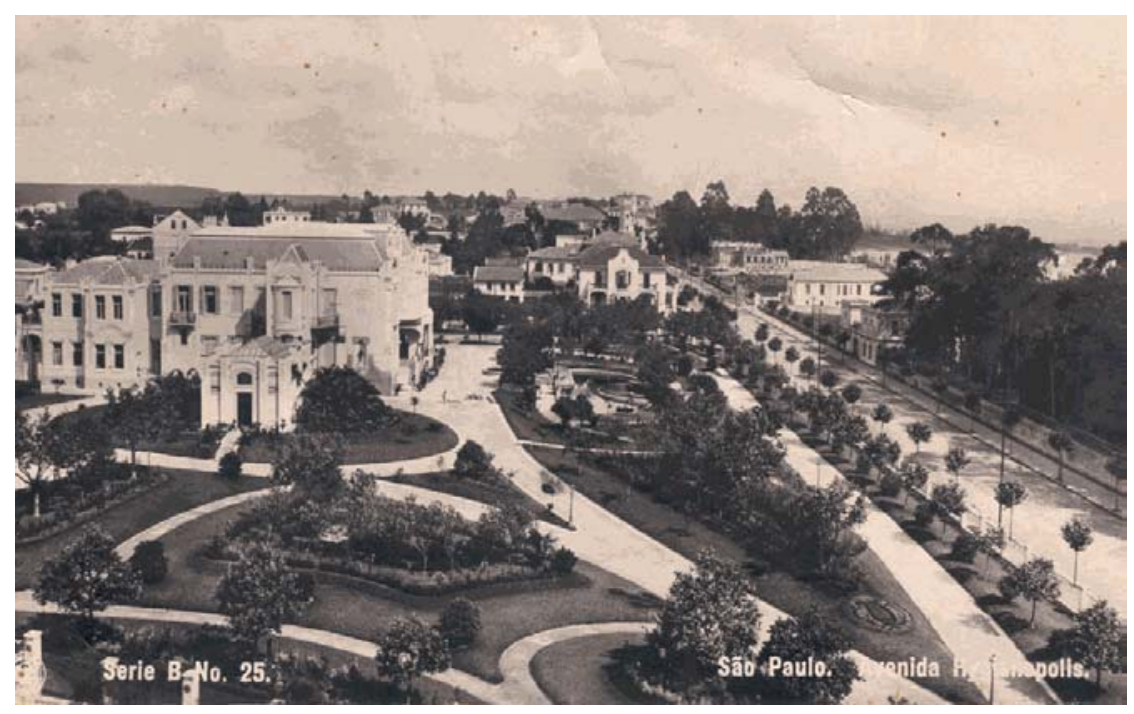

Figura 1. 1 - Vista da edificação Vila Penteado (Postal datado de 20.04.1919)

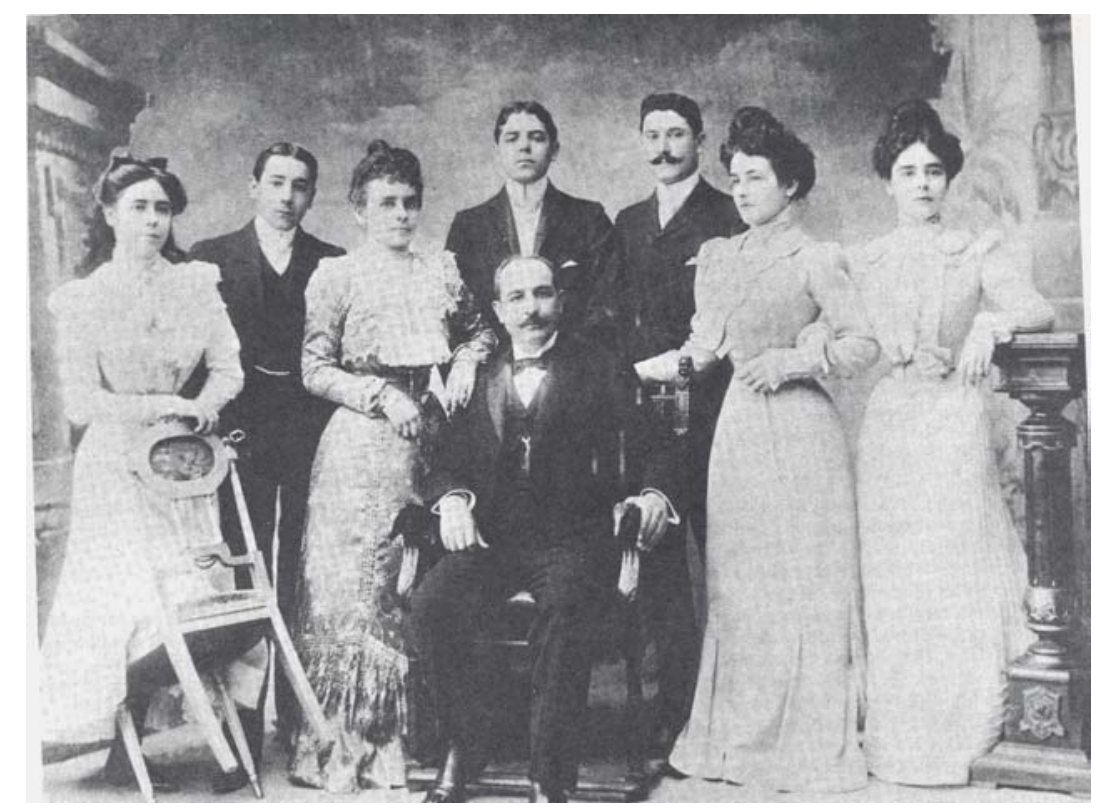

Figura 1. 2 - Família do Conde Antônio Álvares Penteado, no começo do século. Ao centro sentado o Conde; da esquerda para a direita, seus filhos Stella e Armando, Condessa Ana, seu filho Silvio, o genro Caio Prado, as filhas Antonieta e Eglantina. (UNIVERSIDADE DE SÃO PAULO, 1976)

Em 1948 a edificação foi doada para a Faculdade de Arquitetura e Urbanismo da Universidade de São Paulo para sediar o seu curso de graduação. Outros dados sobre esta edificação estão apresentados no Capítulo V e no $\boldsymbol{A n e x o} \boldsymbol{A}$. 
Esta edificação centenária foi tombada como patrimônio histórico pelo CONDEPHAAT $^{1.2}$ em 1978 e em 1991 pelo CONPRESP ${ }^{1.3}$. Em virtude de seu estilo arquitetônico, a edificação é dotada de inúmeros elementos decorativos, dentre os quais destacam-se por seu valor artístico as pinturas murais. Após terem permanecido ocultas durante alguns anos devido a repinturas monocromáticas, esses elementos têm sido recentemente restaurados resgatando a importância de conservação do forro em estuque, onde estão aplicados, de modo a garantir sua perpetuação.

A técnica construtiva empregada no forro em estuque precede a atual, que se caracteriza pela utilização de tela metálica como suporte da argamassa, sendo as camadas de argamassa aplicadas sobre ripas justapostas extraídas do caule de juçara (palmeira Euterpe eudulis).

O levantamento cadastral da edificação permitiu constatar que foi contratada em 1989 uma equipe técnica para fazer a avaliação do estado de conservação das estruturas e componentes de madeira da edificação. Nessa ocasião foi constatada a ocorrência de ataque de cupins de madeira seca no sistema de cobertura e forros de madeira, principalmente nos elementos em Pinho de Riga. Embora não tenham sido encontrados insetos vivos, os resíduos fecais existentes indicaram o ataque de cupins da família Kalotermiditae, provavelmente da espécie Heterotermes brevis. Foi identificado também o severo apodrecimento em partes do forro em estuque do pavimento superior.

\footnotetext{
${ }^{1.2}$ Conselho de Defesa do Patrimônio Histórico, Artístico, Arqueológico e Turístico do Estado de São Paulo

${ }^{1.3}$ Conselho Municipal de Preservação do Patrimônio Histórico, Cultural e Ambiental da Cidade de São Paulo
} 
A deterioração do forro resultou em 1992 na primeira ocorrência de desabamento parcial do mesmo, na varanda do pavimento térreo junto ao cômodo que na ocasião abrigava a mapoteca (biblioteca). O forro do interior desse cômodo também veio a desabar parcialmente em 1994, e desde então algumas medidas de recuperação têm sido sugeridas, mas ainda sem solução definitiva.

Esta pesquisa foi desenvolvida tendo como objetivo principal subsidiar a seleção de um procedimento adequado para restauração do forro em estuque, atendendo ao princípio de que toda intervenção em edificações históricas deve ser precedida de investigação técnico-científica ${ }^{1.4}$.

Este estudo visa contribuir para o resgate da técnica construtiva do forro em estuque, uma vez que foi utilizada em outras edificações nobres do nosso passado recente (período imperial), caracterizando uma herança da colonização portuguesa (SEGURADO, 1936) com influências indígenas ${ }^{1.5}$ (VARGAS, 1994).

\subsection{Atividades de conservação e restauro de edificações históricas}

Conforme consta na BS 7913 "Guide to the principles of the conservation of historic buildings" (BSI,1998), os movimentos de conservação tiveram origem no século XVIII. Porém, até meados do século seguinte não existiam critérios definidos regendo as intervenções, bem como o desenvolvimento de pesquisa científica quanto às técnicas e

\footnotetext{
${ }^{1.4}$ Entende-se por investigação técnico-científica, ou mesmo, de cunho científico a utilização das técnicas mais avançadas de caracterização física e química dos materiais, auxiliando a identificação dos agentes e mecanismos de deterioração.

${ }^{1.5}$ Historiadores e cronistas relatam que a utilização de folhas e caules de palmeiras em habitações era comumente encontrada nas aldeias indígenas (VARGAS, 1994).
} 
materiais empregados na conservação dos monumentos existentes. Somente nesse período surgiram as primeiras discussões sobre porquê intervir e como fazê-10 ${ }^{1.6}$.

Naquela ocasião existiam duas correntes de pensamento principais: a de Ruskin, na Inglaterra, e a de Viollet-Le-Duc, na França. O primeiro acreditava que o monumento deveria ser apenas conservado, preservando o estado original e que novos materiais ou alterações não poderiam ser introduzidos na edificação. Por sua vez, o princípio defendido por Viollet-Le-Duc permite a utilização de novos materiais e técnicas desde que sejam previamente estudados, e tenham seu comportamento previsto a partir de métodos científicos. Este é o princípio mais aceito nos dias atuais, após ter sido incorporado à Carta de Veneza, ao final do II Congresso Internacional de Arquitetos e Técnicos dos Monumentos Históricos, realizado em 1964.

No século XX, a importância do patrimônio histórico e artístico nacional e internacional veio sendo sistematicamente discutida entre políticos, governantes e técnicos especializados. As decisões tomadas em conferências foram registradas em Cartas, Recomendações, Manifestos e Compromissos. O conjunto desses documentos foi denominado por BARROS (1985) de Cartas Patrimoniais. O Anexo B apresenta um quadro resumo das diretrizes consideradas relevantes para restauração de edificações, destacando em itálico as consideradas importantes para esta pesquisa.

Entre os técnicos europeus foi consolidada a divisão da intervenção em três fases:

- levantamento cadastral da edificação;

\footnotetext{
${ }^{1.6}$ Encontram-se citados na norma inglesa os documentos que registraram a preocupação com o assunto, publicados no século XIX: os manuscritos de Scott e Pugin, o manifesto escrito por William Morris em 1877 para a Sociedade de Proteção de Edifícios Antigos, o primeiro Ato dos Monumentos Antigos e a fundação da "National Trust".
} 
- projeto; $e$

- execução.

A primeira fase deve ser desenvolvida por uma equipe multidisciplinar, na qual arquitetos, urbanistas, arqueólogos, historiadores, sociólogos e outros profissionais devem iniciar com o resgate histórico da edificação, de seus proprietários e habitantes, além do meio em que ela está inserida.

Para o bom desempenho do projeto de intervenção, é imprescindível uma avaliação técnica da edificação, incluindo a avaliação dos materiais originais, dos agentes e mecanismos de deterioração. Esta atividade deve ser acompanhada por engenheiros, químicos, biólogos, geólogos e outros técnicos especializados em materiais e técnicas de construção civil. Sendo a avaliação técnica da edificação uma atividade de pesquisa, os técnicos desse campo de atuação têm muito a contribuir com a publicação dos seus resultados.

Quando for escolhida uma nova utilização para a edificação, prática denominada de reabilitaçã $o^{1.7}$, cabe aos arquitetos o estudo da ambientação e harmonização espacial, realizado durante a fase de projeto, baseando-se na avaliação da funcionalidade da edificação.

A execução da obra deve ser realizada por pessoal devidamente treinado, preferencialmente por profissionais observadores, pois a obra pode revelar informações desconhecidas que deverão ser analisadas a cada caso.

${ }^{1.7}$ JOHN et al. (2001) propuseram a denominação modernização ou reforma para todas as modificações ou melhorias em edifícios existentes ou em suas partes, de forma a recuperá-lo de obsolescência. Considerou-se obsolescência a perda de capacidade de um edifício ou de suas partes em satisfazer os seus usuários devido a mudanças nos requisitos de desempenho. 


\subsection{Atividades nacionais de restauro}

Até meados da década de 90, as atividades de restauro em edificações históricas no Brasil pouco evoluíram no que se refere à investigação técnico-científica dos materiais, dos agentes e dos mecanismos de deterioração das edificações. Isto ocorreu quer pela pouca divulgação entre o meio técnico de uma metodologia adequada, quer pelo custo de execução. Acredita-se que também a falta de revistas científicas nacionais contribuiu para a pequena divulgação de trabalhos até esse período. Alguns estudos desenvolvidos recentemente com abordagem técnico-científica de revestimento de edificações históricas têm sido divulgados nos Simpósios Brasileiros de Tecnologia das Argamassas. Esses trabalhos são citados no Capítulo II desta dissertação. As revistas agora existentes, e-Mat ${ }^{1.8}$ e Ambiente Construído ${ }^{1.9}$, também deverão contribuir para preencher essa lacuna de publicações.

O Conselho Nacional para Pesquisa e Desenvolvimento, CNPq, disponibilizou em 2002 recursos financeiros para a formação de redes de pesquisa em restauração do patrimônio histórico nacional. Foram aprovados 18 projetos formando três redes:

- materiais e infra-estrutura;

- processos e técnicas de avaliação e intervenção em bens culturais;

- biodeterioração de monumentos históricos.

Esta dissertação de Mestrado foi desenvolvida no Departamento de Construção Civil da Escola Politécnica da Universidade de São Paulo, com base no conhecimento acumulado no Departamento, principalmente no estudo das argamassas, em prol da preservação do patrimônio histórico edificado desta Universidade. Ela atende à

\footnotetext{
${ }^{1.8}$ Revista eletrônica de ciência e tecnologia de materiais de construção civil (www.e-mat.pcc.usp.br).

${ }^{1.9}$ Revista técnico-científica da Associação Nacional de Tecnologia do Ambiente Construído - ANTAC.
} 
proposta $^{1.10}$ elaborada em 1987, no que se refere à participação da Universidade na preservação de seu próprio patrimônio, utilizando a capacitação técnica de seu corpo docente, associada ao seu papel de formação de especialistas na área. A edificação Vila Penteado da FAUUSP foi citada na proposta mencionada, pela importância de suas pinturas murais, esculturas, trabalhos em madeira, metal e vidro. Esta pesquisa que enfocará o forro em estuque, substrato das pinturas murais, empregou as técnicas de análise por difração por raios-X, análise química, análise petrográfica, porosimetria por intrusão de mercúrio, microscopia eletrônica de varredura e avaliação da sanidade biológica. A aplicação de algumas dessas técnicas ao estudo de argamassa e de concreto já foram detalhadas em trabalhos de dissertação de Mestrado e de Tese de Doutorado na Universidade de São Paulo e no Instituto de Pesquisas Tecnológicas do Estado de São Paulo (QUARCIONI, 1998; SATO, 1998; SHIRAKAWA, 1999).

\subsection{Objetivos}

Os objetivos desta pesquisa são:

a) coleta e sistematização de dados atualizados sobre as diretrizes que regem as intervenções e restauro de edificações históricas;

b) coletar e reunir os dados de intervenções ocorridas na edificação Vila Penteado, bem como dados históricos sobre a sua construção e utilização;

c) contribuir para o resgate histórico da técnica de revestimento em estuque e das características dos materiais empregados;

\footnotetext{
1.10 "Proposta para um programa integrado de preservação e restauração do patrimônio cultural da USP", projeto coordenado pelo Professor Nestor Goulart Reis Filho da Faculdade de Arquitetura e Urbanismo.
} 
d) levantamento das principais técnicas de investigação aplicadas a revestimentos de argamassa de edificações históricas; e

e) fornecer subsídios para a restauração do forro em estuque reforçado com ripas de juçara, com base no estudo dos materiais, da técnica original e da biodeterioração por fungos.

\subsection{Conteúdo}

Visando alcançar os objetivos propostos, este estudo foi baseado numa revisão do estado-da-arte do conhecimento de restauração, no que se refere aos seus princípios, levantamento das técnicas tradicionais de execução de forros em estuque e das experiências internacionais e nacionais de intervenção em revestimentos de argamassa e de suas fases precedentes.

Como as discussões no Brasil sobre restauração e as intervenções em edificações históricas são realizadas principalmente por arquitetos, o Capítulo II objetivou contextualizar os demais profissionais, principalmente os engenheiros, que se ocupam dos serviços de restauro e reabilitação. Este capítulo apresenta um breve histórico das principais instituições internacionais e nacionais que têm atuado, junto ou paralelamente ao Estado, para a preservação das manifestações culturais dos povos e relaciona as principais conferências sobre preservação do patrimônio histórico edificado. Na seqüência é discutida a importância da multidisciplinaridade e da abordagem científica na investigação dos materiais originais e de sua deterioração, subsidiando as decisões técnicas tomadas no processo de restauro. Finalizando, são apresentados os princípios que regem as intervenções, que durante muito tempo foram difundidos somente com publicações sobre a teoria de restauração e das Cartas Patrimoniais, sendo mais recentemente incorporados à normalização internacional. 
O Capítulo III descreve resumidamente experiências anteriores, nacionais e internacionais. Este capítulo reúne os métodos sugeridos na literatura para a caracterização e investigação microestrutural de argamassa evidenciando os mecanismos de deterioração existentes e, por fim, as experiências de restauro sugerindo as tendências.

O Capítulo IV apresenta a metodologia utilizada nesta pesquisa para: a caracterização da argamassa, a investigação da biodeterioração por fungos, a simulação do sistema de restauro proposto e a avaliação de seu desempenho.

O Capítulo V apresenta o levantamento cadastral, a descrição do sistema de forro em estuque da edificação Vila Penteado, o registro cronológico das vistorias, das proposta de intervenções e das intervenções precedentes a este estudo e, por fim, o estado de conservação em que este forro encontrava-se na ocasião da vistoria da obra. Complementa este capítulo a revisão bibliográfica da técnica construtiva de forro em estuque.

O Capítulo VI apresenta os resultados da caracterização da argamassa, da avaliação da biodeterioração do forro por fungos e da avaliação do desempenho do sistema de restauro proposto. Finalizando este capítulo, é apresentada a proposta de intervenção no forro em estuque da edificação Vila Penteado.

O Capítulo VII apresenta as conclusões obtidas neste estudo, as sugestões e recomendações para o avanço do conhecimento da engenharia aplicada à restauração.

Deste texto constam ainda os seguintes anexos:

Anexo A - breve levantamento cadastral da edificação Vila Penteado, incluindo o registro cronológico de vistorias e de intervenções ocorridas na edificação. 
Anexo B - quadro resumo com a relação de eventos sobre a preservação e restauração do patrimônio histórico edificado e dos princípios definidos durante os mesmos.

Anexo C - quadro resumo com a relação de técnicas propostas para a investigação técnico-científica de argamassas históricas em estudos correlatos.

Anexo D - registro fotográfico da vistoria preliminar do forro da edificação Vila Penteado em 1997.

Anexo $\mathrm{E}$ - registro fotográfico da região do forro em estuque da mapoteca, após o colapso parcial ocorrido em 1994, material do arquivo da FAUUSP.

Anexo F -Proposta de fixação do forro em estuque precedente a este estudo, material do arquivo da FAUUSP.

Anexo $\mathrm{G}$ - Resultados da análise de raios $\mathrm{X}$ das amostras de argamassa 


\title{
2 PRESERVAÇÃO DO PATRIMÔNIO HISTÓRICO EDIFICADO
}

\begin{abstract}
"Portadoras de mensagem espiritual do passado, as obras monumentais de cada povo perduram no presente como o testemunho vivo de suas tradições seculares. $A$ humanidade, cada vez mais consciente da unidade dos valores humanos, as considera um patrimônio comum e, perante as gerações futuras, se reconhece solidariamente responsáveis por preservá-las, impondo a si mesma o dever de transmiti-las na plenitude de sua autenticidade." (Carta de Veneza, 1964)
\end{abstract}

Inicialmente, a preservação do patrimônio edificado contribuía para a formação de um "álbum urbano", onde somente monumentos com grande valor histórico e arquitetônico podiam ser encontrados. Ao longo do tempo, com a evolução do conceito de patrimônio, passaram a ser valorizados também alguns exemplares de arquitetura simples e rústica, característicos dos períodos de colonização e formação de algumas sociedades, dentre elas as sociedades primitivas e rurais. Mais recentemente, passou-se a dar importância para a preservação das belezas naturais sobreviventes à ação do homem, pois estas também caracterizam o ambiente no qual estão inseridas as comunidades.

Uma outra tendência foi difundida no Brasil após o Primeiro Congresso Pan-Americano do Patrimônio da Arquitetura, realizado em Ouro Preto em 1992. "O patrimônio da arquitetura não é mais entendido como uma coleção de objetos retirados da dinâmica da vida, mas como um suporte para um processo contínuo de produção da própria vida" (Carta de Ouro Preto, 1992). 
A partir de então, a preservação no Brasil deixou de ter um caráter puramente conservador e de resguardo da história e da arquitetura, incluindo entre seus objetivos a adequação de algumas edificações a novos usos. A reabilitação de centros foi valorizada, integrando estilos arquitetônicos de diversas épocas inclusive o da época contemporânea. Esta tendência vinha sendo implementada internacionalmente e, a exemplo disto, tem-se:

(a) a Assembléia Regional organizada pelo Conselho Internacional dos Museus ICOM - na Ásia em 1982, onde um dos temas discutidos foi "Novas construções e reabilitação de edificações antigas para utilização como museus” e;

(b) o Concurso Internacional para Estudantes de Arquitetura e Urbanismo e Gerenciamento Regional, organizado em 1987 pela IFHP ${ }^{2.1}$, FIHUAT ${ }^{2.2}$ e IVWSR $^{2.3}$, cujo tema foi "A integração do antigo e do moderno nos centros históricos" (L'Integration de L'Ancien et du Moderne dans les Quartiers Historiques). Participaram deste concurso 12 países com 37 projetos.

Na ocasião do Congresso Pan-Americano de Ouro Preto, discutiu-se também o papel social das intervenções. A exemplo, na Itália algumas edificações de valor histórico e arquitetônico vem sendo utilizadas como habitações sociais, principalmente nas regiões centrais onde existe população de baixa renda residindo nessas edificações antes das intervenções.

\footnotetext{
${ }^{2.1}$ IFHP - International Federation for Housing and Planning.

${ }^{2.2}$ FIHUAT - Federation Internationale pour l'Habitation, l'Urbanisme et l'Amenagement de Territoires.

${ }^{2.3}$ IVWSR - Internationaler Verband fur Wohnungswesen Stadtebau und Raumordnung.
} 
Alguns dos principais eventos que contribuíram para a construção desse amplo conceito de preservação do patrimônio edificado estão relacionados resumidamente no item a seguir.

\subsection{Resumo histórico}

\section{Panorama Internacional}

Como já mencionado, alguns movimentos importantes datam do século XIX, mas acredita-se que o "Escritório Internacional dos Museus", organizado pela Sociedade das Nações em Atenas no ano de 1931, resultou no primeiro documento - Carta de Atenas redigido por representantes de diversos países com o objetivo de reunir os princípios básicos e as doutrinas referentes à intervenção em monumentos. Desde então, foram realizadas inúmeras conferências internacionais de cunho político, reunindo Chefes de Estado para a definição de programas de fomento à preservação do patrimônio histórico, e de cunho técnico, complementando as determinações da Carta de Atenas. As Cartas Patrimoniais resultantes dessas discussões reúnem algumas diretrizes a serem seguidas. Entre as principais conferências que abordaram a preservação de monumentos e edificações históricas podem ser citadas:

1933 - Congresso Internacional de Arquitetura Moderna, Atenas;

1964 - II Congresso Internacional de Arquitetos e Técnicos dos Monumentos Históricos, Veneza;

1967 - Reunião sobre Conservação e Utilização de Monumentos e Lugares de Interesse Histórico e Artístico, Quito;

1968 - Conferência Geral da Organização das Nações Unidas para a Educação, a Ciência e a Cultura, Paris; 
1972 - Conferência Geral da Organização das Nações Unidas para a Educação, a Ciência e a Cultura, Paris;

1974 - I Seminário Interamericano sobre Experiências na Conservação e Restauração do Patrimônio Monumental dos Períodos Colonial e Republicano, República Dominicana;

1975 - Congresso do Patrimônio Arquitetônico Europeu, Amsterdã;

1976 - Conferência Geral da Organização das Nações Unidas para a Educação, a Ciência e a Cultura, Nairobi;

1977 - Encontro Internacional dos Arquitetos, Machu Picchu;

1980 - Conselho Internacional de Monumentos e Sítios, Austrália;

1982- Assembléia Mundial dos Estados, Nairobi;

1982 - III Colóquio Interamericano sobre a Conservação do Patrimônio Monumental "Revitalização das Pequenas Aglomerações”, México;

1985 - Conferência Mundial sobre Políticas Culturais, México.

Um quadro resumo das principais decisões tomadas nessas conferências é apresentado no Anexo B. O documento técnico mais conhecido e utilizado como referência mundial até o momento é a Carta de Veneza (1964).

Mesmo com alguns princípios bem definidos, após a Segunda Guerra Mundial vários países da Europa parcialmente destruídos, para não perderem a sua expressão arquitetônica, optaram pela reconstrução de edificações, resgatando as técnicas construtivas originais, em alguns casos já em desusos. Essa prática, denominada de falsificação, desrespeita um dos princípios fundamentais de conservação (cf. o que é proibido em restauro, citado no Quadro B-1 do Anexo B). O valor histórico real somente é atribuído aos edifícios autênticos, e não aos reconstruídos, mas segundo 
ZACHWATOWICZ (1956), a decisão de reconstrução adotada por vários países da Europa contou com o apoio popular e do Estado.

\section{Panorama Nacional}

Pode-se destacar como fatos que mostram a crescente preocupação com o patrimônio histórico no Brasil as seguintes ações:

- a criação do SPHAN $^{2.4}$ em 1937, atual IPHAN ${ }^{2.5}$, seguido da criação de diversas entidades no âmbito estadual, dentre as quais pode-se citar IEPHA/MG ${ }^{2.6}$, INEPAC/RJ ${ }^{2.7}$, CONDEPHAAT/SP, IPAC/BA ${ }^{2.8}$ e IPHAE/RS ${ }^{2.9}$;

- a elaboração de documentos, tais como o Compromisso de Brasília (1 ${ }^{\circ}$ Encontro Dos Governadores de Estado, Secretários Estaduais da Área Cultural, Prefeitos de Municípios Interessados, Presidentes e Representantes de Instituições Culturais) em 1970, o Compromisso de Salvador (II Encontro de Governadores para Preservação do Patrimônio Histórico, Artístico, Arqueológico e Natural do Brasil) em 1971 e a Carta de Ouro Preto (Primeiro Congresso Pan-Americano do Patrimônio da Arquitetura) em 1992;

- a participação de membros do Governo em eventos internacionais, tal como a Convenção Geral da Organização das Nações Unidas para a Educação, a Ciência e a Cultura, em Paris no ano de 1972; que resultou na elaboração do PNC- Plano

\footnotetext{
${ }^{2.4}$ Secretaria do Patrimônio Histórico e Artístico Nacional.

${ }^{2.5}$ Instituto do Patrimônio Histórico e Artístico Nacional.

${ }^{2.6}$ Instituto Estadual do Patrimônio Histórico e Artístico.

${ }^{2.7}$ Instituto Estadual do Patrimônio Cultural

${ }^{2.8}$ Instituto do Patrimônio Artístico e Cultural

${ }^{2.9}$ Instituto de Patrimônio Histórico e Artístico do Estado
} 
Nacional da Cultura para Proteção, Salva-guarda e Valorização do Patrimônio Histórico e Artístico;

- a criação de cursos de especialização em restauração, por exemplo o CECRE Curso de Especialização em Conservação e Restauração de Monumentos e Conjuntos Históricos, implementado pela Universidade Federal da Bahia em 1974; e o CECR - Curso de Especialização em Conservação/Restauração de Bens Culturais Móveis, implementado pelo CECOR - Centro de Conservação e Restauração de Bens Culturais Móveis da Escola de Belas Artes da Universidade Federal de Minas Gerais;

- a criação da Associação Brasileira de Conservadores e Restauradores de Bens Culturais - ABRACOR em 1980;

- a realização do I Seminário Brasileiro para Preservação e Revitalização de Centros Históricos, em Petrópolis no ano de 1987.

- sediar eventos internacionais que discutiram a preservação do patrimônio ambiental, nele incluído o patrimônio edificado; Por exemplo o Encontro de Civilizações nas Américas realizado em Cabo Frio no ano de 1989 e a Conferência Geral das Nações Unidas, realizado no Rio de Janeiro em 1992;

- a revitalização dos centros históricos de inúmeras capitais brasileiras e;

- a aprovação de disciplinas dirigidas ao restauro de edificações e de monumentos históricos no currículo obrigatório das faculdades de arquitetura.

Dentre os fatos citados, destaca-se a criação do SPHAN, órgão federal, que marcou o início do controle das intervenções em edificações e monumentos de valor históricos no Brasil. 


\subsection{Principais instituições internacionais e nacionais}

Inúmeras instituições têm atuado direta ou indiretamente na preservação do patrimônio histórico e artístico, dentre as quais destacam-se as citadas a seguir.

\section{Instituições internacionais}

A Organização das Nações Unidas para a Educação, Ciência e Cultura - UNESCO foi criada durante a Conferência de Londres em 1945. Este órgão reúne 188 países, entre eles o Brasil, e tem como objetivo garantir a paz e os direitos humanos como o direito à educação, à cultura, ao desenvolvimento social e científico, sem distinção de raça, sexo, língua ou religião. Em 1995 haviam escritórios regionais em 60 países, um destes sediado em Brasília desde $1972^{2.10}$. Este órgão em várias ocasiões destacou-se na contribuição e incentivo à preservação do patrimônio dos diversos povos.

O Centro Internacional de Estudos para a Conservação e Restauração dos Bens Culturais - ICCROM - foi criado pela UNESCO em 1956. Esta organização intergovernamental está sediada em Roma desde 1959. Atualmente, o ICCROM conta com mais de 100 países membros, cujos representantes se reúnem bianualmente para tomada de decisões. O Brasil participa deste grupo desde 1964. Esta organização atua em documentação e informação sobre conservação, pesquisas aplicadas, consultoria e técnicas, formação de profissionais (valorizando as particularidades regionais) e sensibilização da importância da conservação e restauração dos monumentos históricos. $^{2.11}$

O Conselho Internacional dos Monumentos e Sítios - ICOMOS - foi fundado em 1965. Esta organização não-governamental dedica-se à conservação dos monumentos e

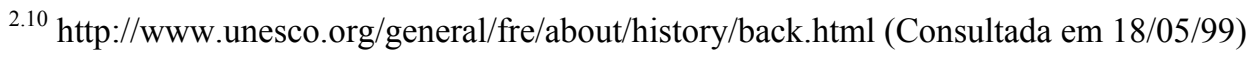

${ }^{2.11} \mathrm{http} / / /$ www.iccrom.org/FRAN/QUESEICC (Consultada em 15/01/98).
} 
sítios históricos do mundo. Atualmente, a sede encontra-se em Paris e conta com Comitês Nacionais em 87 países. Como principal atividade, o ICOMOS tem estabelecido padrões internacionais para a preservação, restauração e gerenciamento do ambiente cultural, tendo sido promulgadas Declarações sobre os temas: análise $e$ restauração de estruturas do patrimônio arquitetônico; arquitetura em terra, estudo e conservação da arquitetura vernacular; arte rupestre; cidades e povoações históricas; economia da conservação; edificações em pedra; edificações em madeira; formação profissional; fotogrametria arquitetônica; gestão do patrimônio arqueológico; jardins e sítios históricos; patrimônio cultural subaquático; pinturas murais; turismo cultural; e vitrais. O Comitê Brasileiro do ICOMOS foi fundado em 1978 no Rio de Janeiro, registrado somente dois anos depois. Atualmente, o Comitê Brasileiro está sediado em São Paulo. O Conselho reúne profissionais de diversas áreas empenhados na preservação do patrimônio histórico edificado e arqueológico. Entre os profissionais que participam do Conselho destaca-se pesquisadores, advogados, arqueólogos, arquitetos, engenheiros, historiadores. ${ }^{2.12}$

BARROS (1995) destacou outras Instituições, como o Centro Regional Latinoamericano de Estudos para a Conservação e Restauração de Bens Culturais do México, a Sociedade de Arquitetos Especializados em Restauração de Monumentos, o Ministério da Instrução Pública da Itália, o Centro Interamericano de Inventário do Patrimônio Histórico e Artístico de Bogotá, a União Internacional de Arquitetos e o Conselho da Europa $a^{2.13}$.

\footnotetext{
${ }^{2.12} \mathrm{http}: / /$ www.geocities.com/RainForest/9468/icomosbr.htm (Consultada em 14/05/99)

${ }^{2.13}$ Não foram encontradas as páginas de divulgação destas Instituições na Internet, rede mundial de computadores.
} 


\section{$\underline{\text { Instituições nacionais }}$}

O Instituto do Patrimônio Histórico e Artístico Nacional - IPHAN - como já mencionado, foi fundado como uma Secretaria - SPHAN em 1937. Do ponto de vista do sociólogo Sérgio Miceli, a criação desta secretaria foi fruto do movimento intelectual e institucional da geração modernista, empenhado em construir uma identidade nacional (NOBRE, 1992). Personalidades nacionais como Mário de Andrade, Manuel Bandeira, Afonso Arinos, Lúcio Costa e Carlos Drummond de Andrade, sob a coordenação de Rodrigo Melo Franco de Andrade foram colaboradores da organização do Instituto. Atualmente, o Instituto está estruturado em 14 Superintendências regionais e 19 Subregionais, sendo responsável pela coordenação de museus, casas históricas, um parque histórico e a cinemateca brasileira, além de outros monumentos e sítios. Dentre 16 mil edifícios tombados, 50 centros e conjuntos urbanos e 5 mil sítios arqueológicos cadastrados, o Brasil conta com nove monumentos culturais e naturais considerados pela UNESCO como Patrimônio da Humanidade. ${ }^{2.14}$

\section{O Conselho de Defesa do Patrimônio Histórico, Artístico, Arqueológico e Turístico do} Estado de São Paulo - CONDEPHAAT - é o órgão criado em 1968 ligado à Secretaria da Cultura do Estado de São Paulo. Atualmente com sede na Rua Mauá, no 51 - Estação Júlio Prestes. Este órgão tem como objetivo a identificação, a valorização e a defesa do patrimônio histórico e cultural paulista. O CONDEPHAAT conta com 25 representantes de Instituições ligadas aos mais diversos setores da sociedade paulista e utiliza-se da figura do tombamento, instituída pela legislação estadual. No total são 312 bens tombados, dentre os quais destacam-se as edificações da Estação da Luz, o Museu do Ipiranga (Parque da Independência), a Casa do Grito, casas bandeiristas que remontam à

\footnotetext{
${ }^{2.14}$ http://www.iphan.gov.br/iphan/iphan.htm (Consultada em: 17/05/99)
} 
época da colonização, edifícios públicos do começo do século e obras da arquitetura contemporânea, como o Museu de Arte de São Paulo - MASP e a Faculdade de Arquitetura e Urbanismo - FAU da USP. ${ }^{2.15}$

O Conselho Municipal de Preservação do Patrimônio Histórico, Cultural e Ambiental da Cidade de São Paulo - CONPRESP - tem sede na Praça Cel. Fernando Prestes $\mathrm{n}^{\circ}$ 152, no Bairro da Luz. O Conselho tem atuado no âmbito municipal, orientando e apresentando diretrizes para elaboração dos projetos de restauro e revitalização. Compete ao Conselho a aprovação de projetos de intervenção em bens tombados e áreas envoltórias e a prestação de informações sobre imóveis e áreas tombadas no Município. Esta última atividade tem um papel educacional, podendo ser programadas visitas monitoradas ao centro histórico da cidade e ao Parque da Independência. Dentre as inúmeras edificações tombadas, destacam-se aquelas construídas em taipa de pilão, muito características da sociedade paulistana (Solar da Marquesa de Santos, Casa do Tatuapé, Casa do Sertanista, Casa do Bandeirante, Casa do Sítio Morrinhos, Casa do Sítio da Ressaca). ${ }^{2.16}$

As informações sobre as instituições internacionais e nacionais acima mencionadas foram obtidas nas páginas de divulgação na Internet, rede mundial de computadores, endereços e datas citadas. As informações foram revistas nas respectivas páginas no ano de 2002.

\footnotetext{
${ }^{2.15} \mathrm{http}: / /$ www.cultura.sp.gov.br/conde-fundo.htm (Consultada em: 12/01/01)

$2.16 \mathrm{http} / /$ infosampa.prodam.sp.gov.br/quiosque/guia/municipal/cultura/pathismu.htm. (Consultada em
} $12 / 01 / 01)$ 


\subsection{Importância da multidisciplinaridade}

As obras de restauro requerem, cada vez mais, a atuação de uma equipe multidisciplinar, devido à complexidade de suas fases, do levantamento cadastral à execução da intervenção. É importante que participem da interpretação dos resultados os especialistas da técnica utilizada e dos materiais analisados, além dos profissionais que participaram da inspeção da edificação. Isto faz com que, na maioria das vezes, um trabalho de restauro seja moroso e tenha um custo elevado, motivos que ainda levam os profissionais envolvidos à opção de embasar o projeto em estudos simplificados.

Apesar do custo, a atuação de uma equipe multidisciplinar utilizando uma abordagem científica se justifica por permitir o avanço do conhecimento quanto aos materiais históricos e às técnicas empregadas, além de auxiliarem nas tomadas de decisão relativas à conservação e preservação dos bens.

A Figura 2.1 mostra as áreas de conhecimento que podem atuar em conjunto num único estudo de restauro, considerando todas as atividades que o compõe.

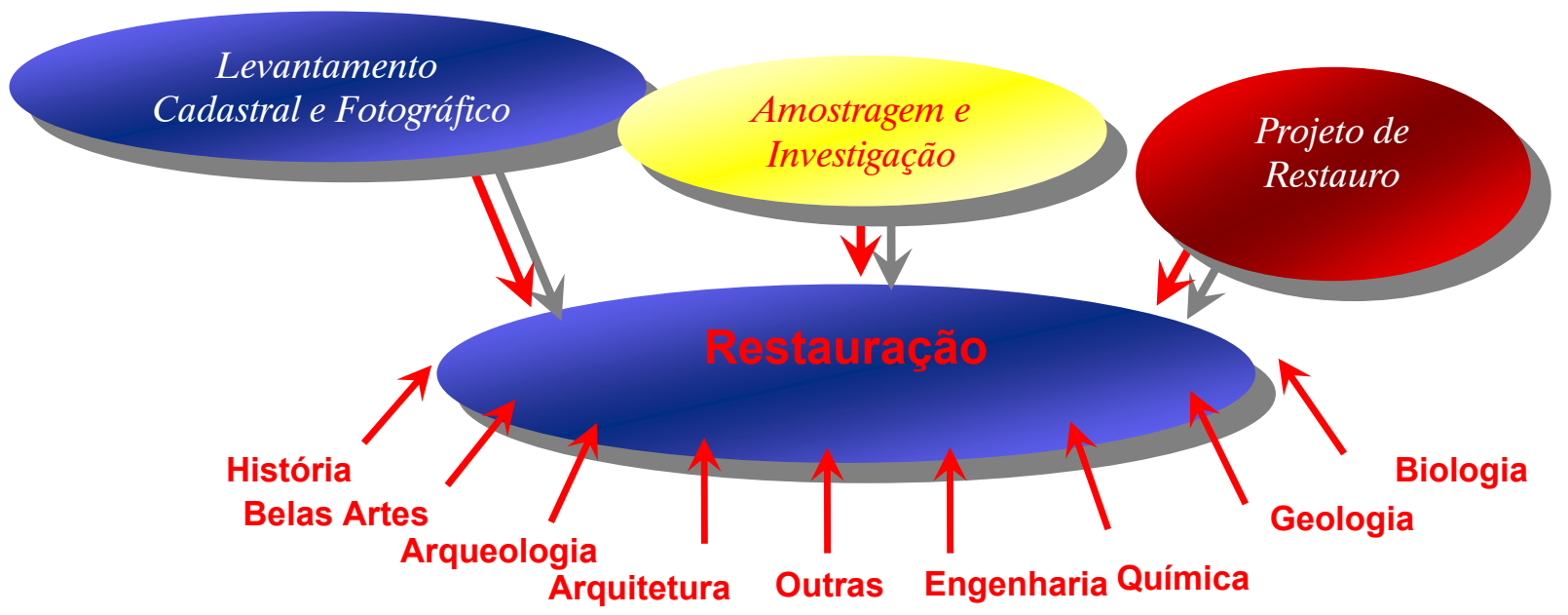

Figura 2.1 - Atividades de restauro de edificações e áreas afins do conhecimento 


\subsection{A abordagem científica na atividade de restauro}

As técnicas científicas de investigação começaram a ser utilizadas há algumas décadas na investigação para preservação de bens culturais e artísticos, principalmente em pinturas e esculturas. Exemplificando, pode-se citar:

(a) o Encontro do Comitê de Laboratórios Científicos em Museus, promovido pelo ICOM, em Moscou e Leningrado em 1963 e,

(b) a criação de escolas para qualificação de profissionais, tal como o Instituto de Formação de Restauradores de Obras de Arte - IFROA - na França em 1978. Neste Instituto, além dos conhecimentos de história da arte, os restauradores têm formação científica principalmente nas áreas de física, química e biologia. Técnicas como análises físico-químicas, difração de raios $\mathrm{X}$, cromatografia gasosa, espectroscopia no infravermelho, microscopia óptica e eletrônica são empregadas para a caracterização dos materiais e a identificação de alterações devido ao envelhecimento.

Mais recentemente, estas técnicas estão sendo introduzidos com maior freqüência no estudo de argamassas de edificações históricas, embora existam ainda poucas publicações que abordem este assunto. Os primeiros trabalhos publicados nesse sentido datam da década de 90 (Anexo $C$ ).

Os dados e informações obtidos podem requerer uma interpretação probalilística devido à inexistência de registros sobre materiais antigos, à heterogeneidade dos mesmos, ou ainda, por serem característicos de técnicas que caíram em desuso. Deve-se acrescer a esses fatores as possíveis interações dos materiais com meio em que estão inseridas as edificações e a ação dos agentes agressivos ao longo dos anos. 
O estudo dos materiais originais de edificações históricas pode seguir o exemplo de estudos arqueológicos, que adota como seqüência de estudo a organização, $a$ construção explicativa e a atribuição.

A organização consiste em sistematizar os dados para obter o significado arqueológico, por exemplo, distinguir a tipologia formando grupos menores; observar objetos com composição semelhantes, comparando-os com base nas características culturais e evolutivas das comunidades a que se referem. A construção explicativa consiste no agrupamento desses objetos pelos minerais constituintes ou pela técnica de execução, ambos visando indicar mesma procedência. A atribuição consiste em agrupar um objeto de procedência desconhecida à uma categoria bem definida. ${ }^{2.17}$

No âmbito nacional alguns pesquisadores têm introduzido técnicas analíticas em estudos de casos de restauro. GOMES;CARVALHO (1997) propuseram a formação de um banco de dados de imagens geradas em microscopia eletrônica de varredura (MEV) para auxiliar o estudo de argamassas históricas e seus fenômenos patológicos. GLEIZE et al. (1999) empregaram análises de difração por raios X (DRX), termogravimetria (TG) e MEV para a caracterização da argamassa de revestimento do Palácio Cruz e Souza de Florianópolis. QUARCIONI et al. (1999-a) sistematizaram a utilização de várias técnicas, tais como análise química, DRX, TG, análise térmica diferencial (ATD), porosimetria por intrusão de mercúrio, análise petrográfica e análise granulométrica dos agregados na proposição de diretrizes de uma normalização brasileira para a caracterização da composição das argamassas de revestimento e assentamento. CAVANI et al. (1999) apresentaram procedimentos de investigação aplicando análise

\footnotetext{
2.17 http://www.culture.fr/culture/conservation/fr/cours/folfo.htm\#Retour 2 (consultado em 17/05/1999)

"Méthodologies scientifique appliquées à l'archeéométrie et à la conservation-restauration"
} 
química, apreciação em lupa estereoscópica e análise granulométrica e de formulação de argamassa para o restauro do revestimento de fachada de uma edificação da década de 30 na cidade de São Paulo.

\subsection{Princípios que regem as intervenções}

Além dos inúmeros documentos elaborados durante os eventos promovidos para a salvaguarda do patrimônio histórico (Anexo B), também as publicações sobre a teoria da restauração reúnem princípios relevantes que regem as intervenções. BRANDI (1995) discutiu numa esfera filosófica o papel da restauração de uma obra de arte, partindo do seu reconhecimento como tal e enumerou dois princípios:

"Primeiro Princípio: restaura-se somente a matéria da obra de arte;

Segundo Princípio: a restauração deve dirigir-se ao restabelecimento da unidade potencial da obra de arte, sempre que isto for possível, sem cometer uma falsificação artística ou histórica e sem apagar marcas do transcurso da obra de arte através do tempo."

Com relação ao primeiro princípio, pode-se citar que pinturas de valor artísticos não devem receber a marca do restaurador. O segundo princípio pode ser aplicado à limpeza de fachadas de edificações históricas, que não deve remover a pátina acumulada, deixando assim visível a marca do tempo que complementa o seu aspecto estético. É importante verificar nesses casos se a pátina não compromete a integridade da obra.

Ainda segundo BRANDI (1995), a matéria que é objeto de restauro pode estar ou não intimamente ligada ao que se considera como a obra de arte. É exemplo típico a pintura sobre madeira, onde a camada de pintura e o suporte em madeira podem requerer intervenções diferenciadas e em momentos diferentes. No caso da edificação Vila Penteado, o forro em estuque é o suporte das pinturas murais de valor artístico que necessitam ser preservadas. 
Alguns países contam com normas como a mencionada BS 7913 (BSI,1998). O item

6.2.2 desta norma enumera o que ela considera como princípios básicos:

(a) necessidade de especialistas aplica-se a todas as fases da intervenção, em alguns casos sendo necessário o resgate de técnicas históricas;

(b) valorização e respeito a todos os registros históricos da edificação, independentemente das fases e períodos em que foram incorporados;

(c) necessidade de pesquisas, investigações, avaliações e registros antes e durante qualquer intervenção (diário da edificação), construindo a história contemporânea da edificação e possibilitando intervenções futuras adequadas;

(d) fidelidade à condição original; Sempre que possível, os materiais e elementos da edificação devem ser mantidos no local original;

(e) é inaceitável a destruição de evidências históricas importantes sem o registro adequado; Caso sejam necessárias, as alterações devem ser exaustivamente registradas;

(f) intervenção por razões estéticas deve ser devidamente registrada e permanecer facilmente distinguível do original, podendo ser discretamente datada e;

(g) documentação em duas vias de todas as evidências e informações reunidas no decorrer das intervenções, mantendo-se uma cópia na edificação e a outra devidamente arquivada.

Essa Norma aborda ainda outros temas, dentre os quais destacaram-se os relacionados na Tabela 2-1. 
Tabela 2- 1 Temas e assuntos abordados pela BS 7913 (BSI,1998)

\begin{tabular}{|c|c|c|c|}
\hline Temas & \multicolumn{2}{|c|}{ Assuntos } & Itens da $B S 7913$ \\
\hline \multirow{9}{*}{ Definição } & Alteração ${ }^{2.18}$ & Preservação ${ }^{2.19}$ & \multirow[t]{9}{*}{ 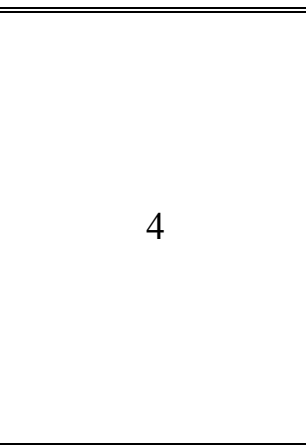 } \\
\hline & Arqueologia & Proteção & \\
\hline & Conservação & Reintegração & \\
\hline & Área de conservação & Reconstrução & \\
\hline & Conversão & Reparo/recuperação ${ }^{2.20}$ & \\
\hline & Projeto & Replicação & \\
\hline & Materiais & Restauração $^{2.21}$ & \\
\hline & Intervenção & Reversibilidade & \\
\hline & Manutenção & & \\
\hline \multirow{7}{*}{ Preservação } & \multicolumn{2}{|c|}{ Harmonização das modificações estéticas } & \multirow{7}{*}{$\begin{array}{c}6.2 .4 \\
7.2 .7 \\
7.5 .2 \\
7.5 .4 \\
7.6 \\
7.7\end{array}$} \\
\hline & \multicolumn{2}{|c|}{ Ponderação do desempenho estrutural e estético } & \\
\hline & \multicolumn{2}{|c|}{ Intervenção mínima e abordagem conservadora } & \\
\hline & \multicolumn{2}{|c|}{ Envelhecimento e manutenção da intervenção } & \\
\hline & \multicolumn{2}{|c|}{ Elementos e flexibilidade do projeto } & \\
\hline & \multicolumn{2}{|c|}{$\begin{array}{l}\text { Proteção e preservação de artefatos móveis e } \\
\text { imóveis da edificação }\end{array}$} & \\
\hline & \multicolumn{2}{|c|}{$\begin{array}{l}\text { Monitoramento da perturbação causada pela } \\
\text { intervenção (edificação e entorno) }\end{array}$} & \\
\hline
\end{tabular}

${ }^{2.18}$ Intervenção com o objetivo de introduzir modificações funcionais em artefatos e edificações ou com modificação de sua aparência; Ex: atividades de reabilitação de alguns centros, adequação a novos usos.

${ }^{2.19}$ Estado de perpetuação de uma edificação ou artefato, quer por um acaso histórico ou pela combinação da proteção e conservação.

${ }^{2.20}$ Intervenção num artefato ou edificação danificados, visando restabelecer as características alteradas devido à deterioração - envelhecimento natural ou desgaste - ou aos danos causados por acidente ou negligência. Exclui-se para tanto, as atividades de alteração e restauração.

${ }^{2.21}$ Intervenção num artefato ou edificação danificados, com objetivo de resgatar a aparência e as características de uma determinada época (na maioria das vezes remetendo-se à época da criação ou construção). 
Continuação da Tabela 2- 1 Temas e assuntos abordados pela BS 7913 (BSI,1998)

\begin{tabular}{|c|c|c|}
\hline Temas & Assuntos & Itens da $B S 7913$ \\
\hline \multirow{3}{*}{$\begin{array}{l}\text { Recuperação } \\
\text { (Abordagem } \\
\text { conservadora) }\end{array}$} & Intervenção mínima & \multirow{3}{*}{$\begin{array}{l}\text { 7.3.1; } \\
\text { 7.3.2.4 }\end{array}$} \\
\hline & $\begin{array}{l}\text { Resgate e utilização preferencial de materiais e } \\
\text { técnicas tradicionais com a figura do artesão }\end{array}$ & \\
\hline & $\begin{array}{l}\text { Restrição a técnicas e materiais com } \\
\text { conseqüências desconhecidas e aprendizado com } \\
\text { a experiência acumulada }\end{array}$ & \\
\hline \multirow{7}{*}{ Restauração } & Restauração x autenticidade da edificação & \multirow{7}{*}{7.3 .2} \\
\hline & Casos em que se aplica a restauração & \\
\hline & Registro das intervenções & \\
\hline & $\begin{array}{l}\text { Resgate e utilização preferencial de materiais e } \\
\text { técnicas tradicionais }\end{array}$ & \\
\hline & Materiais novos - vantagens e precauções & \\
\hline & $\begin{array}{l}\text { Compatibilidade com sistema construtivo e } \\
\text { materiais originais }\end{array}$ & \\
\hline & $\begin{array}{l}\text { Restrição a técnicas e materiais com } \\
\text { conseqüências desconhecidas e aprendizado com } \\
\text { a experiência acumulada }\end{array}$ & \\
\hline \multirow{3}{*}{ Manutenção } & Utilização preferencial de cuidados simplificados & \multirow{3}{*}{$\begin{array}{l}7.1 .3 \\
7.2 .1\end{array}$} \\
\hline & $\begin{array}{l}\text { Participação do usuário na manutenção } \\
\text { preventiva, periódica e corretiva }\end{array}$ & \\
\hline & Tomada de decisões fundamentadas & \\
\hline
\end{tabular}




\section{EXPERIÊNCIAS DE RESTAURO - ABORDAGEM PARTICULAR EM REVESTIMENTO DE ARGAMASSA}

Geralmente as experiências relatadas nas publicações consultadas caracterizam-se ou por apresentar sucintamente os métodos empregados na fase de investigação dos materiais originais e incorporados à edificação durante sua existência, ou por apresentar algumas medidas corretivas especificadas em projetos de restauro.

Como exaustivamente recomendado nas Cartas Patrimoniais, a intervenção deverá ser sempre precedida de investigação de técnico-científica da obra, na qual o projeto de intervenção deverá estar baseado. Esse estudo torna-se indispensável nos casos de reabilitação quando são previstas alterações na utilização da edificação, sendo necessária a adequação de suas instalações. A ausência desse estudo, ou mesmo falhas na interpretação de seus resultados, pode implicar em manifestações patológicas em proporção mais avançada que as oriundas do envelhecimento natural.

Para PIANA; ARMANI (1981), o processo de intervenção conta com três atividades principais: documentações cadastral e fotográfica; amostragem e investigação dos materiais originais e projeto de restauro.

A documentação cadastral pode também ser denominada de levantamento cadastral da edificação e consiste na reunião de informações sobre a edificação. Esta atividade pode ser subdivida em levantamento histórico e levantamento técnico da edificação. A amostragem e o planejamento da investigação são elaborados visando caracterizar os materiais empregados na edificação e fornecer subsídios para a especificação de 
materiais e técnicas de recuperação ou restauração. Estas atividades de levantamento, amostragem e investigação são fundamentais para a elaboração de um projeto de restauro adequado e de um planejamento orçamentário mais próximo dos investimentos reais.

\subsection{Levantamento cadastral}

Do ponto de vista dos órgãos de preservação do patrimônio, o Levantamento Histórico deve ser constituído do histórico da edificação, da sua região ou entorno, incluindo a documentação de todos os bens móveis e imóveis encontrados na edificação, principalmente quando essa se encontra abandonada. As informações reunidas durante esta fase podem auxiliar a interpretação das causas das manifestações patológicas presentes. Por exemplo, o tipo de utilização da edificação e a ocorrência de intervenções inadequadas podem influenciar significativamente no avanço do envelhecimento natural e/ou na deterioração dos materiais, em especial quando estes processos já tiverem sido desencadeados.

O Levantamento Técnico é constituído da análise critica da documentação técnica existente sobre a edificação e da sua investigação, que inicia pela inspeção visual.

Informações quanto à caracterização do estilo arquitetônico e quanto às técnicas construtivas empregadas, bem como o registro e a análise técnica das intervenções realizadas, são consideradas relevantes para o Levantamento Técnico. Estas atividades dependem fundamentalmente da experiência dos profissionais envolvidos, pois durante a existência da edificação detalhes construtivos característicos de diferentes estilos podem ter sido incorporados à mesma por decisão de seus usuários. A substituição ou sobreposição de serviços (por exemplo, diversas camadas de revestimento ou pintura) indica intervenções anteriores, podendo caracterizar diferentes fases históricas da 
edificação. A inexistência de projetos originais, ou muitas vezes as diferenças entre os projetos e a edificação construída, requer um minucioso levantamento.

As modificações existentes podem ser verificadas pela execução de um levantamento da distribuição geométrica e espacial da edificação. $\mathrm{Na}$ maioria das vezes, este levantamento não requer equipamentos especiais e resulta em subsídios importantes para a avaliação da funcionalidade da edificação. A avaliação quanto à funcionalidade da edificação é pertinente para os casos onde a utilização for diferente da prevista na concepção do projeto original.

As avaliações do estado de conservação e da estabilidade da edificação devem ser consideradas como as atividades mais importantes a constar no Levantamento Técnico da edificação. Esta avaliação é ainda mais importante nos casos de reabilitação, onde estejam previstas modificações de utilização, incorrendo na modificação da solicitação da estrutura. Cabem neste momento, ensaios não destrutivos, tais como prova de carga na estrutura e esclerometria nos elementos estruturais em concreto. Se devidamente justificados, podem ser realizados ensaios destrutivos, tais como resistência à compressão em testemunhos extraídos da estrutura e resistência de aderência em revestimentos $^{3.1}$. A avaliação destes resultados é uma atividade bastante complexa, uma vez que os resultados obtidos nos ensaios podem não atender às especificações atuais. Nem por isso o objeto avaliado deverá ser condenado, sendo necessário avaliar também a sua estabilidade, aceitando ou não a sua utilização.

A avaliação visual dos materiais inseridos na edificação é provavelmente a etapa que fornece mais subsídios para a interpretação das análises em laboratório, que constituem

\footnotetext{
${ }^{3.1}$ Este ensaio será comentado no item 3.1.1 por estar relacionado com o estudo de caso abordado nesta dissertação.
} 
o estudo dos materiais originais ${ }^{3.2}$. Dada a sua importância, é recomendável que as informações obtidas sejam registradas fotograficamente. Quando associada à etapa de amostragem, a avaliação visual deve fornecer a descrição genérica das amostras e, principalmente, do meio em que estavam inseridas, incluindo as manifestações patológicas observadas. Informações quanto às dimensões, à homogeneidade do material e à presença de "ninhos" ou de falhas de execução devem ser obtidas durante esta atividade. O monitoramento do microclima pode complementar a avaliação visual, auxiliando na tomada de decisão quanto ao método de saneamento a ser utilizado para algumas manifestações patológicas.

Em virtude do valor patrimonial das edificações, consideram-se fundamentais para conduzir ao diagnóstico das manifestações patológicas existente todas as atividades propostas por LICHTENSTEIN (1986) - vistoria do local, anamnese, exames complementares e pesquisa - como mostra o esquema da Figura 3.1.

$3.2 \mathrm{O}$ estudo dos materiais originais, caracterização e avaliação microestrutural, podem ou não participar da composição do levantamento técnico. Devido à sua importância, nesta Pesquisa será abordado em detalhe separadamente. 


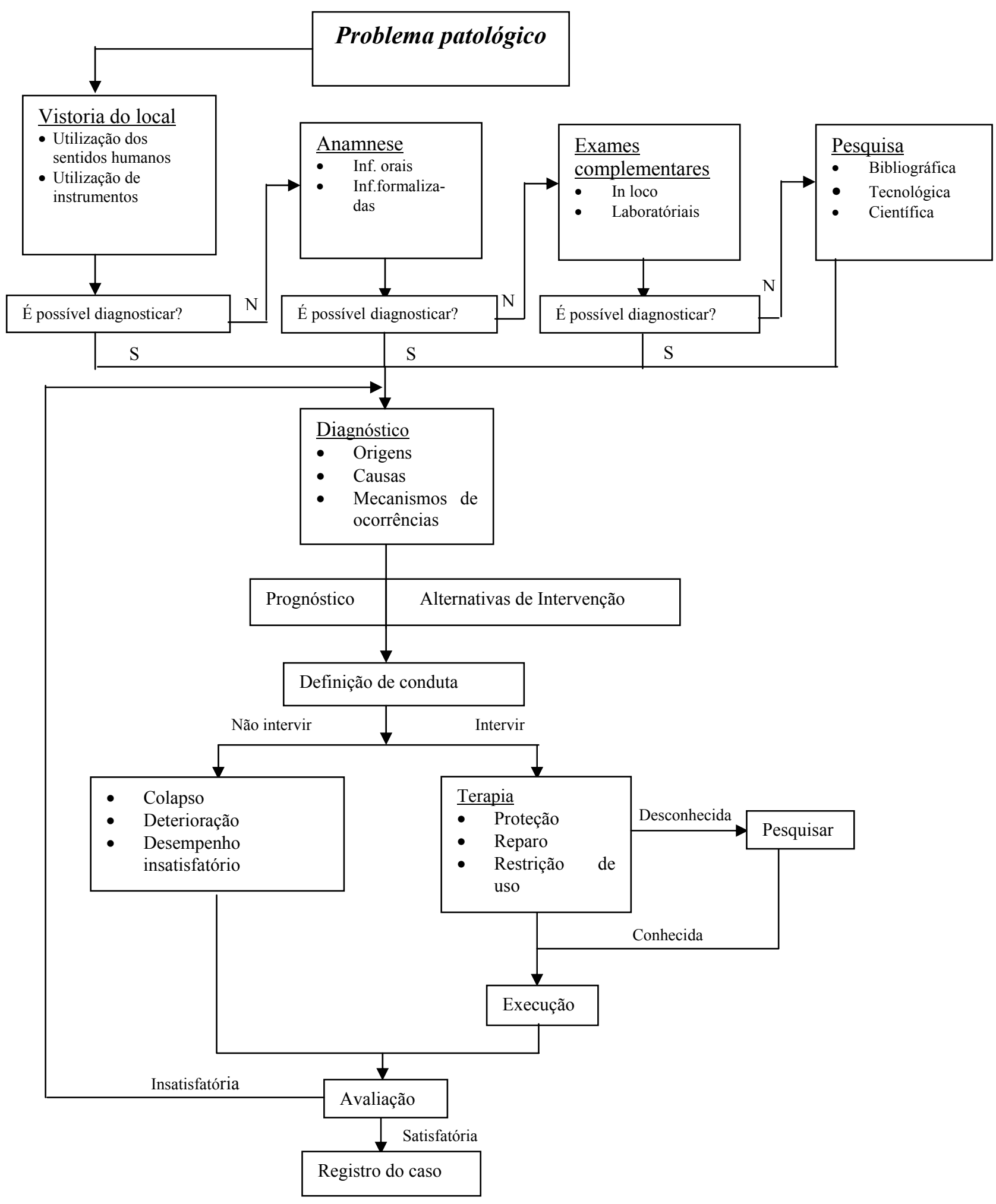

Figura 3.1 - Fluxograma de atuação para a resolução de problemas patológicos. (LICHTENSTEIN, 1986)

As informações obtidas durante o Levantamento Técnico são tradicionalmente sistematizadas em Relatórios Técnicos elaborados por uma equipe multidisciplinar. 
ÁNGEL et al. (1995) propõem que em edificações de valor histórico todas as informações pertinentes a este levantamento sejam agrupadas em documentos informatizados, empregando quando disponível a técnica de tratamento digital de imagens. Por meio de plantas originais digitalizadas da edificação deve ser possível acessar todas as informações relevantes, tais como a descrição dos materiais constituintes, o estado de conservação, as intervenções realizadas e informações quanto ao avanço da deterioração. Para tanto, faz-se necessária a identificação das causas e o monitoramento das manifestações patológicas. Este tipo de registro tem sido realizado em algumas edificações históricas na Espanha, o que tem facilitado as atividades de reabilitação, recuperação e manutenção.

Vale ressaltar que o Levantamento Técnico da edificação também pode ter contribuição histórica, principalmente no que tange a materiais e técnicas que caíram em desuso. A exemplo desta contribuição pode-se citar o trabalho de CAMPITELLI (1990), que ressaltou a importância da etapa do levantamento técnico do Templo de Esculápio, no jardim da residência Villa Borghese em Roma, não só para subsidiar as intervenções, mas para revelar particularidades dos materiais e técnicas de execução dos estuques e pinturas originais, representativos de uma época.

\subsubsection{Ensaio in-loco - resistência de aderência em revestimentos}

A determinação da resistência de aderência em revestimentos de edificações históricas tem suas restrições por ser um ensaio destrutivo que abrange uma área significativa. No entanto, este ensaio pode estar combinado com a amostragem para outras análises quando esta informação for fundamental.

A NBR 13.528 "Revestimentos de paredes e tetos de argamassas inorgânicas Determinação da resistência de aderência à tração - Método de ensaio" (ABNT, 1995) 
prescreve o método de ensaio e a NBR 13.749 "Revestimentos de paredes e tetos de argamassas inorgânicas - Especificação" (ABNT, 1996) determina a resistência de aderência de revestimentos de argamassa em interiores e em exteriores.

\subsection{Levantamento bibliográfico das técnicas construtivas}

As técnicas e procedimentos historicamente empregados para a execução do serviço em questão devem ser resgatados visando auxiliar a interpretação dos resultados obtidos durante a fase de caracterização dos materiais originais. Para tanto, o levantamento bibliográfico sobre os procedimentos descritos em "manuais de construção" são bastante úteis. Vale ressaltar que estes procedimentos podem ter sofrido alguma alteração durante sua transcrição, uma vez que não foram redigidos pelos artesãos conhecedores das técnicas, mas provavelmente por observadores de sua atuação.

\subsection{Estudo dos materiais empregados - análise de argamassa em laboratório}

Como observado no quadro resumo dos estudos correlatos, apresentado no Anexo $C$, a metodologia empregada na Europa para a análise de argamassas históricas está baseada na tendência atual de caracterização e avaliação microestrutural dos materiais de construção civil. A utilização de análise por difração de raios X, análise termogravimétrica, análise química, análise petrográfica, observação por microscopia eletrônica de varredura e porosimetria por intrusão de mercúrio é citada no estudo de argamassas, sendo estas complementadas pela caracterização dos agregados.

QUARCIONI et al. (1999-a) apresentaram as diretrizes básicas para a investigação de argamassas, discutindo algumas técnicas e avaliando comparativamente os procedimentos de normas americana e britânica. 


\subsubsection{Amostragem}

A BS 4551 "Methods of testing mortars, screeds and plasters" (BSI, 1998) contempla diretrizes específicas para três objetivos: avaliação da homogeneidade da argamassa empregada na edificação; definição da composição de regiões específicas; e definição da composição média.

Para avaliação da homogeneidade da argamassa, a amostragem deve ser feita de forma aleatória na edificação, sendo as amostras armazenadas e analisadas separadamente. Os resultados devem ser considerados representativos somente da região de coleta.

Para a definição da composição de regiões específicas a norma prescreve que a amostragem seja em regiões previamente selecionadas, seja por apresentarem manifestações patológicas, seja por apresentar alguma particularidade. A localização das amostras deve ser minuciosamente descrita. As amostras também devem ser armazenadas e analisadas de forma independente.

Por fim, para se obter a composição média, as amostras devem ser constituídas de subamostras de massas aproximadamente iguais e espaçadas regularmente, de modo a representar uma área da edificação. Deve-se evitar que as amostras sejam representativas predominantemente de regiões de fácil extração, falseando o resultado das análises.

A coleta de amostra pode, em alguns casos, ser associada a ensaios destrutivos (por ex. determinação de resistência de aderência), desde que o ensaio destrutivo não interfira nos resultados das análises a serem realizadas.

Acredita-se que o procedimento de amostragem descrito pela BS 4551, "Methods of testing mortars, screeds and plasters” (BSI, 1998) seja propício para a fase de investigação das atividades de restauro. Porém, o procedimento de amostragem para 
definir a composição média pode ser pouco usual por se confrontar com o princípio da intervenção mínima.

\subsubsection{Avaliação visual}

A avaliação visual em laboratório resultará numa descrição específica da amostra, podendo enriquecer as informações obtidas na inspeção da edificação em função dos recursos disponíveis, tais como lupa estereoscópica e reagentes específicos. Esta etapa também auxiliará na preparação adequada das amostras, uma vez que revestimentos constituídos com mais de uma camada devem ter cada uma previamente separada quando destinadas a análises específicas (análise química, DRX, porosimetria por intrusão de mercúrio, etc.). Quando as camadas não puderem ser separadas, a amostra pode ser analisada na íntegra. Cada situação deve ser devidamente registrada, sendo considerada na análise dos resultados. A combinação de diferentes técnicas de análise é bastante útil nestes casos.

Considerando que a maioria das argamassas convencionais não é pigmentada, a coloração das mesmas pode indicar a presença de argila em sua constituição, ou até mesmo a ocorrência de biodeterioração.

A observação detalhada em lupa estereoscópica das amostras de argamassa de reboco da Medina Azahara na Espanha, por exemplo, facilitou a identificação de fissuras, do descolamento na interface agregado-aglomerante (relacionado com a dissolução do aglomerante) e de colônias microbiológicas (BLANCO-VARELLA et al. 1997).

\subsubsection{Análise por difração de raios X (DRX)}

A análise por difração de raios $\mathrm{X}-\mathrm{DRX}$ - é complementar às análises química, térmicas e petrográfica, todas direcionadas para a determinação da composição da argamassa (aglomerantes e agregados). O resultado desta análise orienta a 
reconstituição da composição, a partir da identificação das espécies químicas presentes e orienta o método de análise.

Esta análise permite identificar qualitativamente as fases cristalinas dos materiais, por meio da análise das intensidades dos espectros de difração dos raios $\mathrm{X}$ associados aos ângulos em que estas são verificadas. A identificação dessas fases é geralmente obtida pela comparação do espectrograma com os dados do arquivo do JCPDS - Joint Committee on Powder Diffraction Standards, onde estão catalogadas mais de 30.000 espécies químicas. Segundo PADILHA;AMBRÓZIO F(1985), constituintes com fração inferior a 5\% são dificilmente identificados, pois confundem-se com a radiação de fundo.

Cita-se como exemplo de aplicação desta técnica, o estudo de argamassas medievais da Cantábria, Espanha, realizado por GUTIERREZ-SOLANA et al. (1989). As amostras coletadas foram submetidas à análise por DRX em duas fases. Na primeira fase a argamassa foi analisada integralmente, visando identificar os minerais constituintes, enquanto na segunda fase a amostra foi constituída somente do resíduo insolúvel ao ataque de ácido clorídrico, visando identificar a natureza dos agregados. Neste estudo, a análise por DRX foi utilizada para obter uma avaliação semi-quantitativa, embora a maioria das pesquisas consultadas a empreguem para uma análise qualitativa.

\subsubsection{Reconstituição da proporção aglomerante : agregado por análise química}

QUARCIONI (1998) documentou o conhecimento acumulado nas últimas décadas no Laboratório de Química dos Materiais do IPT, onde o Método IPT para reconstituição da proporção aglomerante : agregado de concretos, publicado em 1940, foi adaptado para argamassas simples e mistas à base de cimento Portland, cal e agregado quartzoso. 
Este pesquisador fez uma atualização do método, considerando as adições que são atualmente incorporadas aos aglomerantes. O método não é recomendado para argamassas com cimentos pozolânicos, materiais argilosos e agregados carbonáticos, devido às premissas consideradas para o cálculo. A reconstituição da proporção dos constituintes da mistura, proposta por este método, está baseada nos resultados de técnicas de análise química por gravimetria e titulometria, considerando que os aglomerantes (cimento Portland e cales cálcica e dolomítica) são solúveis em ácido clorídrico, sendo o resíduo insolúvel correspondente ao agregado.

A ASTM C 1324 "Standard Test Method for Examination and Analysis of Hardened Masonry Mortar" (ASTM, 1996) amplia a "gama" de argamassas analisadas por via úmida, incluindo as argamassas mistas de cimento Portland, cimento de alvenaria e argamassas com agregado carbonático. Para tanto, o cálculo da reconstituição da proporção dos constituintes baseia-se na análise química (determinações dos teores de sílica solúvel, de óxido de cálcio, de óxido de magnésio, resíduo insolúvel e perda ao fogo), análise petrográfica, DRX e DTA (Análise Térmica Diferencial).

A BS 4551 (BSI, 1998) recomenda que a análise química seja realizada utilizando as seguintes técnicas: gravimetria (destina-se à determinação de umidade, perda ao fogo a $1000{ }^{\circ} \mathrm{C}$, resíduo insolúvel, sílica solúvel, e trióxido de enxofre); complexometria (óxido de cálcio, óxido de magnésio e óxido de alumínio) e colorimetria/titulometria (óxido de ferro), podendo ainda ser utilizada alternativamente a espectrofotometria de absorção atômica. Quando houver interesse na determinação de cloreto, a amostra analisada deve ter granulometria inferior a $0,60 \mathrm{~mm}$ (peneira $\mathrm{ABNT}$ n. $\left.{ }^{\circ} 30\right)$. Esta norma restringe-se a argamassas de agregado quartzoso e com aglomerantes solúveis ao ataque ácido (cimento Portland, cimento de alvenaria, cal cálcica e gesso), porém permite a 
reconstituição da proporção dos constituintes da mistura para argamassa com agregado carbonático quando conhecida a composição química do mesmo.

Da mesma forma que o Método IPT, as duas normas citadas recomendam que sejam considerados valores de materiais de referência no cálculo para a reconstituição da proporção aglomerante : agregado quando for desconhecida a composição química dos materiais empregados.

STEWART; MOORE (1981) avaliaram três métodos de análise química, visando à reconstituição da proporção dos constituintes de argamassas históricas: um proposto por Jedrzejewska, outro por Cliver e o terceiro pela ASTM C85-66/71 "Standard Methods of Test for Cement Content of Hardened Portland Cement Concrete". Segundo esses pesquisadores, o método proposto por Jedrzejewska era bastante empregado na Europa, na ocasião, para classificação das argamassas históricas quanto à hidraulicidade. Este método está baseado na determinação volumétrica do dióxido de carbono, $\mathrm{CO}_{2}$ (considerado estequiometricamente combinado com o $\mathrm{CaO}$, na proporção $1: 1$ ) e na determinação gravimétrica do teor de areia e do teor de sílica solúvel, este último associado à hidraulicidade da argamassa.

O método proposto por Cliver (STEWART; MOORE, 1981) está baseado na determinação gravimétrica da fração solúvel (aglomerantes), fração de areia e fração fina do resíduo insolúvel. Este método classifica a fração fina do resíduo insolúvel pela coloração obtida. A cor cinza escuro foi considerada proveniente do cimento, pois o autor do método considerou que 40\% do cimento Portland era insolúvel em ácido; a cor vermelha foi associada à presença de argila; e a cor marrom relacionada ao cimento natural, o que justifica o alto teor de resíduo insolúvel. 
O método da ASTM C85-66/71 (STEWART; MOORE, 1981) está baseado na determinação de sílica solúvel. O método recomenda que, para o cálculo do teor de cimento Portland, assuma-se que $21 \%$ do mesmo é constituído de sílica solúvel.

STEWART; MOORE (1981) consideraram que nenhum dos métodos avaliados era propício à reconstituição da composição das argamassas históricas, embora o proposto por Jedrzejewska tenha apresentado a melhor aproximação dos teores de areia e sugerido a possível utilização de aglomerante hidráulico. O método da ASTM foi considerado como limitado às argamassas com alto teor de cimento Portland, tendo pouca aplicabilidade para argamassas históricas, geralmente sem cimento. Dada as limitações dos métodos para reconstituição da proporção dos constituintes das argamassas pela realização isolada da análise química, STEWART; MOORE (1981) propuseram como complemento a avaliação da composição mineralógica pela análise petrográfica e cristalográfica.

Compartilhando dessa opinião, FRIZOT (1981) sugeriu que a análise química clássica seja precedida pela caracterização do agregado e complementada pela determinação de sílica solúvel proveniente da cal hidráulica ou das adições pozolânicas, utilizando a espectrofotometria de absorção atômica ou a fluorescência de raios X.

Dentre os métodos expostos, considera-se o método do IPT (QUARCIONI, 1998) eficiente e mais adequado para argamassas brasileiras, pois introduziu fatores de correção no cálculo, obtidos a partir de sua aplicação no estudo de argamassas com composição conhecida e produzidas com os materiais nacionais.

\subsubsection{Termogravimetria - TG}

A análise por termogravimetria relaciona a perda de massa devida ao aquecimento da amostra com a transformação térmica dos seus constituintes e quantifica a fração volátil. 
A faixa de temperatura da reação de transformação indica a composição mineralógica do material.

Devido às limitações da maioria dos equipamentos, se analisa aproximadamente $1 \mathrm{mg}$ de material, geralmente com granulometria inferior a $75 \mu \mathrm{m}$ (peneira ABNT n. ${ }^{\circ} 200$ ). Em alguns casos, devido à pequena quantidade de material analisada, pode ser interessante empobrecer por peneiramento a quantidade de areia presente na argamassa.

A Tabela 3-1 apresenta algumas faixas de temperatura de transformação de espécies químicas presentes em materiais comuns nas edificações.

Tabela 3- 1 Espécies químicas e suas respectivas faixas de temperatura de transformação (ZAMPIERI, 1993).

\begin{tabular}{|c|c|c|}
\hline $\begin{array}{c}\text { Temperatura } \\
{ }^{\circ} \mathrm{C} \\
\end{array}$ & $\begin{array}{c}\text { Composição mineralógica } \\
\text { dos materiais }\end{array}$ & Reação de transformação \\
\hline Até 100 & Umidade & Evaporação \\
\hline $160-170$ & $\begin{array}{l}\text { Sulfato de cálcio dihidratado } \\
\text { (gipsita) }\end{array}$ & $\begin{array}{l}\text { Transformação em sulfato de cálcio } \\
\text { hemidratado }\end{array}$ \\
\hline 200 & $\begin{array}{l}\text { Sulfato de cálcio hemihidratado } \\
\text { (gesso de construção) }\end{array}$ & $\begin{array}{l}\text { Transformação em sulfato de cálcio } \\
\text { anidrita III ou anidrita solúvel em água }\end{array}$ \\
\hline 360 & Hidróxido de magnésio (brucita) & $\begin{array}{l}\text { Desidroxilação do hidróxido de } \\
\text { magnésio }\end{array}$ \\
\hline $450-470$ & Hidróxido de cálcio (porlandita) & Desidroxilação do hidróxido de cálcio \\
\hline $500-640$ & Anidrita III & Anidrita II ou anidrita insolúvel em água \\
\hline 575 & Quartzo alfa & $\begin{array}{l}\text { Transformação de quartzo alfa em } \\
\text { quartzo beta }\end{array}$ \\
\hline $620-640$ & Carbonato de magnésio & $\begin{array}{l}\text { Descarbonatação do carbonato de } \\
\text { magnésio }\end{array}$ \\
\hline $\begin{array}{l}670 \\
645-710\end{array}$ & Carbonato de cálcio (calcita) & Descarbonatação do carbonato de cálcio \\
\hline $\begin{array}{l}810-830 \\
\text { e } 880-900\end{array}$ & $\begin{array}{l}\text { Carbonato de cálcio e } \mathrm{e} \\
\text { magnésio }\end{array}$ & $\begin{array}{l}\text { Decomposição em duas etapas, a } \\
\text { primeira devido à descarbonatação do } \\
\text { carbonato de magnésio e a segunda } \\
\text { devido à descarbonatação do carbonato } \\
\text { de cálcio. }\end{array}$ \\
\hline
\end{tabular}

As transformações assinaladas na Tabela 3-1 são da estrutura cristalina das espécies químicas e não registram variações de massa. 
A análise termogravimétrica foi utilizada no estudo de CINCOTTO (1977) para caracterização de cales hidratadas para construção civil produzidas no Estado de São Paulo.

SAKAR et al. (1994) utilizaram a termogravimetria no estudo de argamassas do Memorial Victoria, em Calcutá, que segundo os pesquisadores auxiliou na caracterização do aglomerante e da pátina existente na superfície das argamassas.

\subsubsection{Análise granulométrica do agregado}

A análise granulométrica deve ser realizada com vistas a caracterizar o agregado utilizado. O agregado, separado da pasta por ataque com ácido, é classificado de acordo com a sua distribuição granulométrica, definida por peneiramento e pipetagem.

A BS 4551 (BSI, 1998) descreve minuciosamente o procedimento de ataque químico nas amostras destinadas à análise granulométrica dos agregados.

Para o peneiramento podem ser utilizadas somente as peneiras da série normal definida pela NBR 7.217 "Agregados - Determinação da composição granulométrica" (ABNT, 1987) para a avaliação e a classificação de areias, ou ainda poderão ser utilizadas as peneiras intermediárias.

FRIZOT (1981) sugeriu que os resultados da análise granulométrica apresentem a curva de distribuição granulométrica, a mediana e o índice de triagem, que foi definido pelo autor como indicador do quão uniforme é a distribuição em torno da mediana.

\subsubsection{Análise petrográfica}

A análise petrográfica, consagrada na análise de rochas, veio sendo difundida inicialmente para estudos da microestrutura de concreto e, mais recentemente, de argamassas de revestimento e de assentamento aplicadas (Anexo C). OLIVEIRA et. al. (1999) descreveram o método de análise petrográfica aplicado no IPT para as 
argamassas. A análise petrográfica propicia a observação da distribuição de fases (pasta, agregados e vazios), das características texturais e estruturais da argamassa. Contudo, esta técnica tem como principal limitação a escala. É uma ferramenta adequada para observação de grãos de tamanho médio variando de $\pm 0,020$ a $20 \mathrm{~mm}$. Por outro lado, é pouco adequada para grãos menores que $5 \mu \mathrm{m}$, o que dificulta a distinção de aglomerantes ou outras adições na pasta. Nesses casos, opta-se pela análise por microscopia eletrônica de varredura.

De acordo como a ASTM C 1324 (ASTM.1996), esta análise auxilia a interpretação dos resultados da análise química. Para tanto, são coletadas informações sobre:

- argamassa - aparência, características resultantes da preparação da amostra, superfícies de fratura, interface com outros materiais, substâncias secundárias;

- agregados - composição mineralógica, natureza, estrutura, tipo, homogeneidade, granulometria, interface com a matriz, fissuras e microfissuras no agregado e produtos de reação álcali-agregado;

- pasta - produtos de hidratação e carbonatação, produtos constituintes residuais, minerais como calcários e dolomitos e adições como escória, pozolanas, argilas e pigmentos;

- vazios - distribuição, tipologia, diâmetro relativo e sua proporção em relação à pasta;

$\mathrm{e}$

- produtos secundários.

LUXÁN et al. (1995) utilizaram a análise petrográfica durante a fase de caracterização das argamassas da fachada da Basílica de Santa Engrácia na Espanha e comprovaram a presença de argilo-minerais, não evidenciando se originários de adições ou da jazida do agregado. 
A análise petrográfica permitiu que SAKAR et al. (1994) observassem a presença de cristais de sulfato de cálcio dihidratado no interior dos poros da argamassa de cal com agregado quartzoso e calcário utilizada no Memorial Victoria em Calcutá. A presença dessa espécie química nos poros da argamassa de cal foi associada com a sulfatação da argamassa decorrente das emissões $\mathrm{SO}_{2}$ na atmosfera.

\subsubsection{Observações da microestrutura por microscopia eletrônica de varredura (MEV)}

A observação da microestrutura por microscopia eletrônica de varredura está contribuindo cada vez mais para a caracterização dos materiais de construção civil. Apesar da técnica ainda ser utilizada principalmente com enfoque ilustrativo, a mesma tem contribuído para estudos com abordagem de ciência dos materiais.

O microscópio eletrônico de varredura possui resolução superior ao microscópio óptico, podendo ainda se determinar os elementos químicos presentes pela microanálise de energia dispersiva (EDS). A capacidade de aumento nominal, em equipamentos hoje disponíveis é de até $3 \times 10^{5}$ vezes, com resolução na ordem de nanômetro $\left(10^{-9} \mathrm{~m}\right)$. A observação com aumento próximo ao nominal resultaria em imagens de pouca resolução e muito específica, não sendo praticada.

No estudo de argamassas do século XVI, coletadas em obras da República Dominicana, LUXÁN; DORREGO (1996) utilizaram a microscopia eletrônica de varredura para avaliação de cristais carbonáticos, podendo inferir que de acordo com a morfologia apresentada (Figura 3.2), a calcinação da cal da época era realizada em fornos a lenha. 


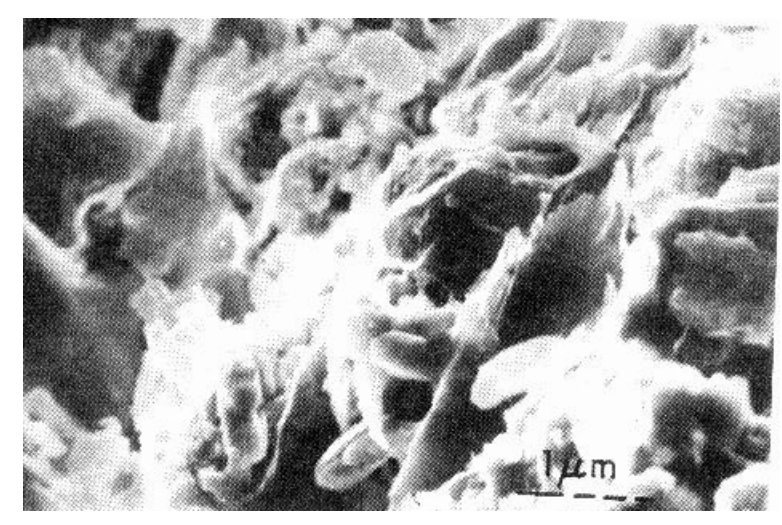

(a)

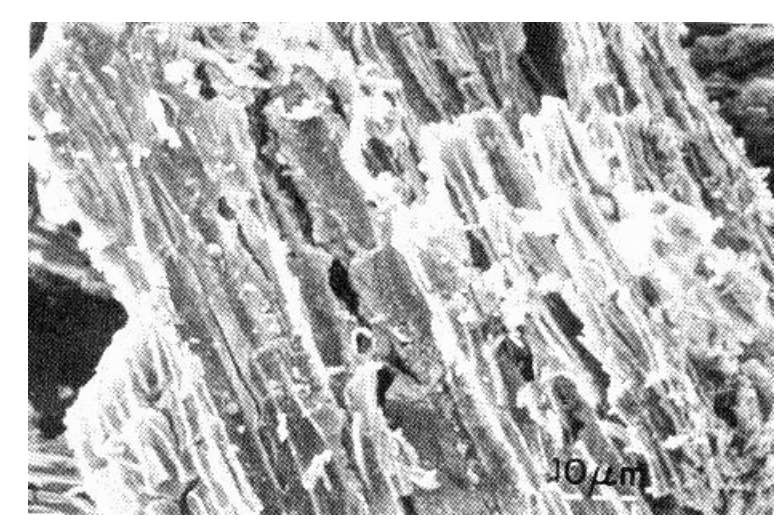

(b)

Figura 3.2 - (a) Cristais de carbonatos de cálcio formados na argamassa de cal; (b) Morfologia das partículas carbonáticas (LUXÁN; DORREGO, 1996).

Nesse mesmo trabalho, a observação por microscopia eletrônica de varredura permitiu a identificação do silicato de cálcio hidratado, C-S-H, formado pela reação da cal com a argila oriunda do calcário, não identificado por DRX, uma vez que os picos de intensidade deste mineral confundiam-se com o ruído de fundo ou encontravam-se sobrepostos a outros picos (Figura 3.3). 


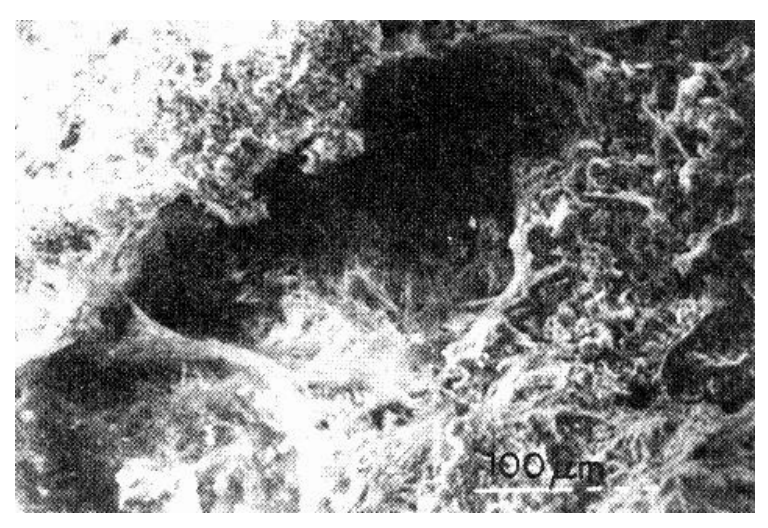

(a)

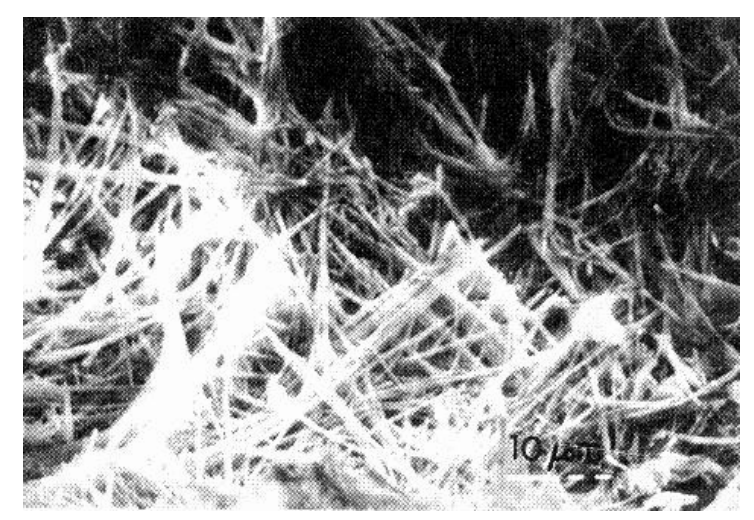

(b)

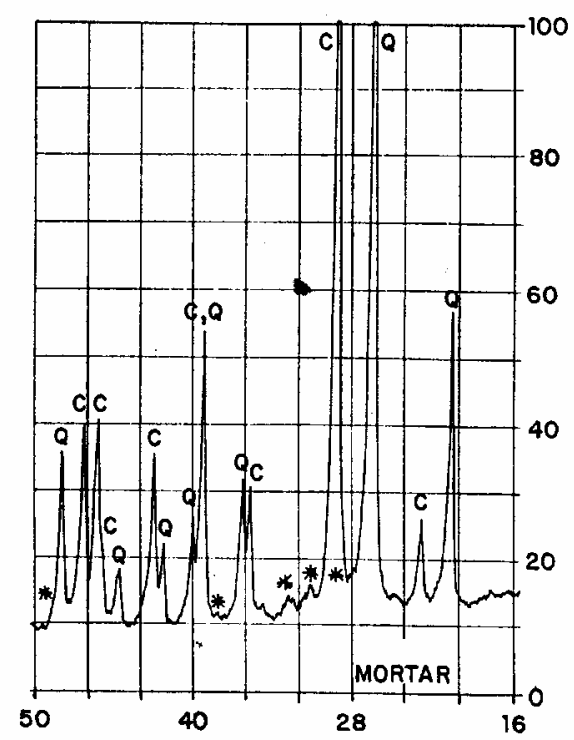

(c)

Figura 3.3 - (a) Cristais de C-S-H no interior do poro; (b) Maior magnificação do C-S-H presente na micrografia (a); e (c) DRX da amostra de argamassa analisada (LUXÁN; DORREGO, 1996). 
A biodeterioração da argamassa e das rochas do Memorial Victoria, Calcutá, (SARKAR et al., 1994) foi registrada em microscopia eletrônica de varredura (Figura 3.4). Esta técnica evidenciou a lixiviação do aglomerante, pois se constatou a presença de vazios (Figura 3.5).

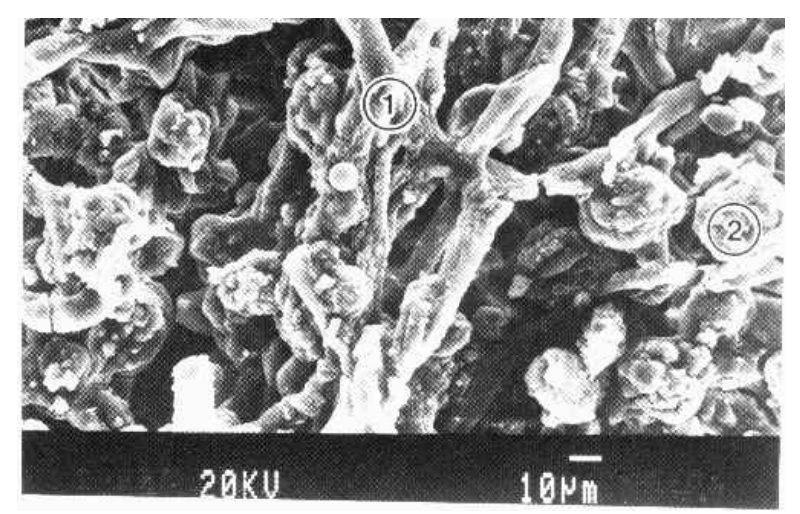

Figura 3.4 - Microorganismos identificados nas amostras de argamassa empregada no Memorial Victoria - região (1) estruturas fibrilares e região (2) estrutura granular (SARKAR et al., 1994).

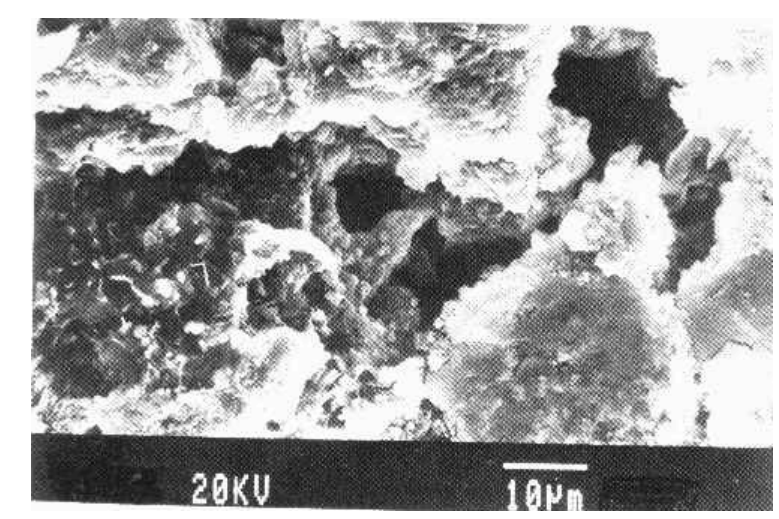

Figura 3.5 - Forma dos poros da argamassa, característicos da lixiviação do aglomerante (SARKAR et al., 1994).

\subsubsection{Porosimetria por intrusão de mercúrio}

A porosimetria por intrusão de mercúrio enriquece o estudo dos materiais com informações quanto ao volume e à distribuição do tamanho de poros. Esta análise abrange poros da ordem de $200 \mu \mathrm{m}$ a $2 \mathrm{~nm}$, para pressões de até $420 \mathrm{MPa}$, valor que 
corresponde à capacidade nominal dos instrumentos disponíveis (REED, 1995). O método utiliza o mercúrio devido à sua baixa molhabilidade e por suportar a pressão exercida para forçar sua penetração. Os resultados obtidos são apresentados, usualmente, em curvas do volume acumulado da penetração de mercúrio pela massa dos corpos-de-prova em função do raio dos poros, evidenciando a distribuição dos diâmetros de poros.

SARKAR et al. (1994) determinaram a porosidade de amostras de argamassas retiradas de regiões com diferentes graus de conservação do Memorial Victoria, em Calcutá. Uma porosidade maior foi verificada na amostra da região que apresentava pátina esverdeada, o que levou estes pesquisadores associarem o aumento da porosidade à biodeterioração.

\subsubsection{Isolamento e identificação de fungos}

O isolamento e a identificação dos fungos é utilizado para comprovar a presença desses microorganismos, associando-os com a biodeterioração dos materiais de construção civil.

Embora a presença de fungos seja mais comum em materiais de origem orgânica, como papéis de parede, madeira, tinta e vernizes, estes microorganismos podem ser encontrados em argamassas inorgânicas de assentamento ou revestimento. A Figura 3.6 ilustra as etapas da análise microbiológica para identificação dos fungos.

Algumas variações no procedimento de coleta podem ser adotadas em função da material disponível e nos meios de cultura em função dos microorganismos a serem cultivados. Por exemplo, mais recentemente SHIRAKAWA (1999) usou alternativamente ao "swab" (cotonete, indicado na Figura 3.6) um retalho de carpete 
Capítulo 3

Experiências de Restauro - Abordagem particular em revestimento de argamassa

estéril. Quanto ao meio de cultura, esta pesquisadora adotou o Ágar Sabouraud Dextrose (Oxoid) ao invés do Ágar Batata Dextrose.

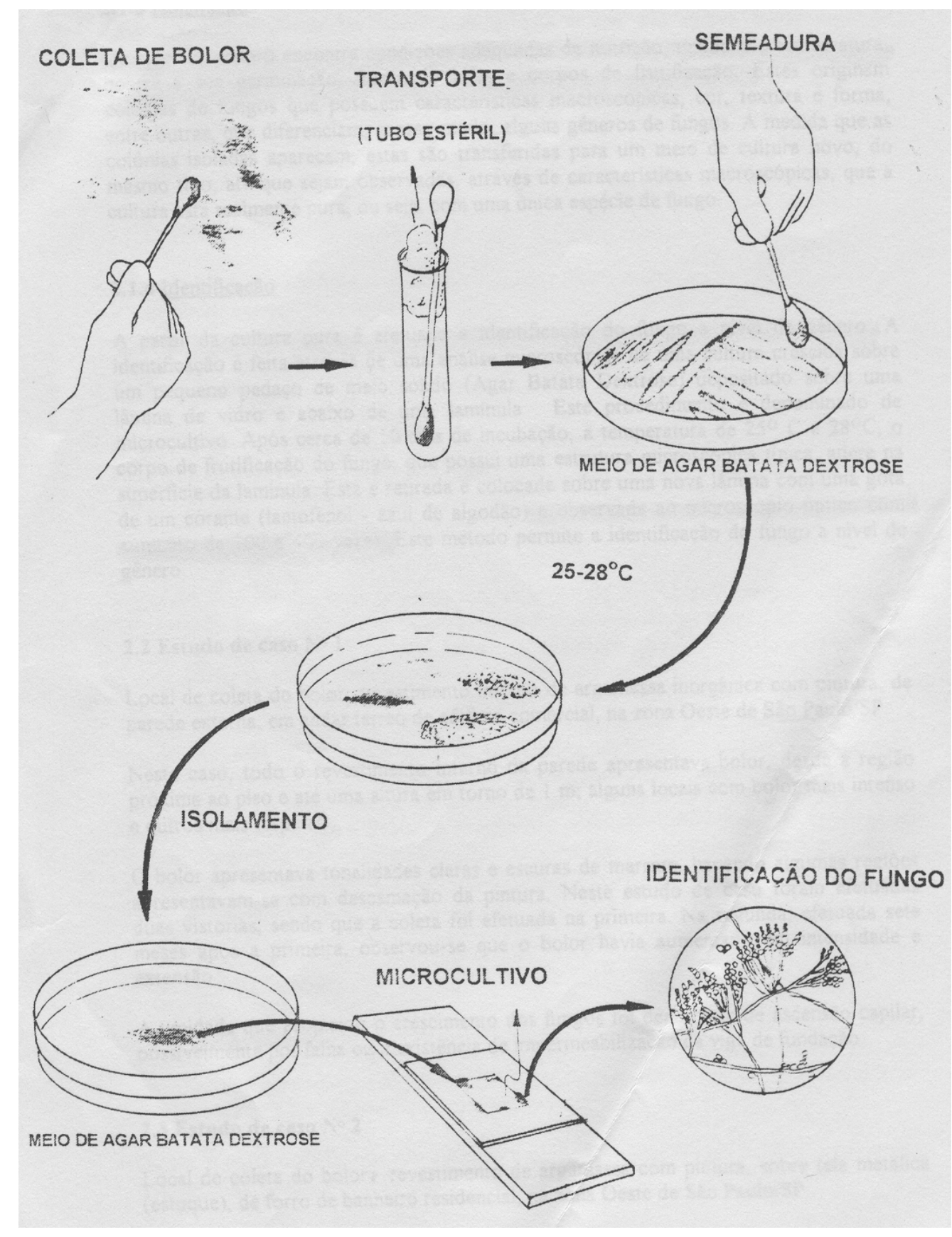

Figura 3. 6 - Etapas da análise microbiológica efetuada para identificação dos fungos, nos revestimentos com bolor (SHIRAKAWA et al., 1995). 
Em argamassa têm-se estudado predominantemente a ação de fungos, algas, podendo, eventualmente, atuar bactérias e líquens (simbiose de algas e fungos). PERRICHET (1987, apud SHIRAKAWA, 1999) identificou fungos, bactérias e algas em revestimentos externos, relacionando-os com a orientação das fachadas em que se encontravam e as respectivas cores evidenciadas nas manchas, como apresenta a Tabela 3-2.

Tabela 3- 2 Microorganismos colonizadores e orientação respectiva das fachadas (PERRICHET (1987) apud SHIRAKAWA (1999))

\begin{tabular}{|c|c|c|c|c|}
\hline $\begin{array}{l}\text { Cores das } \\
\text { manchas }\end{array}$ & Fungos & Bactérias & Algas & Ocorrências \\
\hline Verde & $\begin{array}{l}\text { Cladosporium } \\
\text { cladosporioides } \\
\text { Phoma } \\
\text { Aureobasidium }\end{array}$ & $\begin{array}{l}\text { Bactérias } \\
\text { sulfo- } \\
\text { oxidantes }\end{array}$ & $\begin{array}{l}\text { Aphanocapsa } \\
\text { nostoc } \\
\text { Gloeocapsa } \\
\text { Calothrix } \\
\text { Chlorococaceae } \\
\text { Ulothricaceae }\end{array}$ & $\begin{array}{l}\text { Superfícies } \\
\text { lisas } \\
\text { rugosas } \\
\text { Face norte }\end{array}$ \\
\hline Preta & $\begin{array}{l}\text { Cladosporium } \\
\text { cladosporioides } \\
\text { Alternaria } \\
\text { tenuissima } \\
\text { Arthrinium }\end{array}$ & & $\begin{array}{l}\text { Aphanocapsa } \\
\text { Gloeocapsa } \\
\text { Menos freqüentes } \\
\text { Calothrix } \\
\text { Trentepholia }\end{array}$ & $\begin{array}{l}\text { Fachada } \\
\text { oeste }\end{array}$ \\
\hline Vermelha & $\begin{array}{l}\text { Cladosporium } \\
\text { cladosporioides }\end{array}$ & & $\begin{array}{l}\text { Trentepholia } \\
\text { Aphanocapsa }\end{array}$ & $\begin{array}{l}\text { Fachada } \\
\text { norte, } \\
\text { nordeste } \\
\text { sudoeste }\end{array}$ \\
\hline Efeitos & $\begin{array}{l}\text { Produção de ácidos } \\
\text { orgânicos e enzimas } \\
\text { hidrolíticas }\end{array}$ & $\begin{array}{l}\text { Produção de } \\
\mathrm{H}_{2} \mathrm{SO}_{4}\end{array}$ & $\begin{array}{l}\text { Produção de ácido } \\
\text { orgânico }\end{array}$ & \\
\hline
\end{tabular}

Além das colorações indicadas na Tabela 3-2, para SHIRAKAWA et al. (1995) as manchas marrons, esbranquiçadas e/ou amareladas também podem ser associadas à presença de fungos, sendo as duas últimas menos freqüentes.

No Curso de Biodeterioração de Museus e Patrimônio, organizado pela Divisão de Produtos Florestais do IPT em dezembro de 2000, divulgou-se para o meio técnico presente que a análise de biologia molecular tem possibilitado significativa evolução na caracterização de organismos quanto a espécies e linhagens. Esta técnica aplica-se ao 
estudo dos agentes de biodeterioração de difícil identificação, com a finalidade de, por exemplo, diferenciar espécies de bactérias atuantes. A aplicação desta técnica continua restrita a casos muito específicos, mas deve ser considerada como forte tendência para futuras pesquisas aplicadas à biodeterioração de patrimônio histórico.

\subsubsection{Outras técnicas}

Outras técnicas podem ser empregadas visando complementar a caracterização das argamassas. A espectroscopia no infravermelho é geralmente empregada na identificação de produtos orgânicos. LUXÁN et al. (1995) e QUARCIONI et al. (1999b) utilizaram esta técnica para a identificação de aditivos em argamassas.

No estudo de CAMPITELLI (1990) sobre o Templo de Esculápio, na Villa Borghese em Roma, amostras do revestimento pigmentado e do estuque foram destinadas à análise químico-estratigráfica para determinação da natureza dos materiais e dos produtos de alteração. No mesmo trabalho, utilizou-se análise com microssonda eletrônica e análise de imagem por incidência de raios infravermelhos para obter informações sobre as cores originais do edifício, composição do estuque e seu método de execução. A análise dos resultados obtidos com a utilização dessas técnicas indicou:

- a presença de uma camada de argamassa à base de cal e gesso, com pigmentos ocre-amarelado e negro-carbono aplicada sobre quase toda a superfície da edificação. Esta pigmentação foi considerada como responsável pela homogeneização do substrato constituído de vários materiais;

- a presença de uma camada de argamassa sobre a anterior com tonalidade mais intensa pela presença de oxalato de cálcio e;

- estuque constituído de argamassa de cal e pó-de-mármore (proporção média $2: 1$ ), apresentando aproximadamente $5 \%$ de gesso de construção. 


\subsection{Métodos de intervenção}

A proposta de intervenção depende da postura do projetista. No entanto, qualquer proposta deverá levar em consideração alguns princípios básicos, dentre os quais ressalta-se o citado no artigo $9^{\circ}$ da Carta de Veneza:

"Quando as técnicas tradicionais revelarem-se inadequadas podem ser empregadas técnicas modernas, cuja eficácia tenha sido avaliada cientificamente e comprovada pela experiência."

Por algumas décadas houve grande difusão da utilização do cimento e do concreto na intervenção em monumentos históricos, independente dos materiais originais, como previsto nas recomendações da Carta de Atenas ${ }^{3.3}$. Este procedimento está sendo extinto devido às manifestações patológicas ocorridas pela falta de uma avaliação adequada da compatibilidade dos materiais usados na intervenção e dos materiais originais.

MORICONI (1990) relatou alguns problemas ocorridos em edificações que foram recuperadas com argamassas de cimento. A formação da etringita (trissulfoaluminato hidratado) e da taumasita (um silicato de cálcio hidratado com íons carbonato e sulfato substituintes) ocorreram em edificações nas quais foram identificadas a presença de sulfato. Segundo MORICONI (1990), o sulfato pode ter sido oriundo de gesso de construção, utilizado em argamassas antigas, dos elementos de alvenaria ou do meio externo.

\footnotetext{
3.3 "Eles aprovaram o emprego adequado de todos os recursos da técnica moderna especialmente do cimento armado.” (BARROS, 1995; p.16)
} 
Segundo LAGUNES (1990), no México, a restauração de exemplares da arquitetura privada tem sido realizada pelos artesãos, membros da própria comunidade, os quais muitas vezes empregam técnicas e materiais tradicionais (cal virgem, sal de cozinha, óleo vegetal, cola de peixe, sabão, pigmentos vegetais e minerais). Os órgãos governamentais de tutela do patrimônio histórico desse país têm defendido o resgate das técnicas tradicionais, difundindo seu conhecimento pela publicação de manuais.

BOCCHINO (1990) também defendeu esta postura. Para este pesquisador, a utilização de técnicas e materiais similares aos originais, além de ser o procedimento mais comum de restauro de revestimentos e ornamentos, é o que garante a preservação da obra. Este pesquisador sugeriu ainda que seja empregada uma mão-de-obra de formação intermediária entre os profissionais altamente treinados para restauro e os que atuam na indústria da construção civil tradicional.

Esta postura "tradicionalista" tem sido difundida no Brasil pela pesquisadora do IPHAN/SC Isabel Kanan. Segundo KANAN (1995), atualmente países como a Dinamarca, Suécia, Grécia, Itália e Inglaterra estão resgatando a prática da utilização de cal na recuperação de argamassas de revestimento e pinturas murais, afresco e caiações, a partir da criação de projetos para o desenvolvimento científico e prático do emprego deste material.

Esta postura está baseada no princípio da compatibilidade, ou seja, os materiais empregados na restauração devem possuir compatibilidade física e química, além da resistência mecânica e da durabilidade ser similar ou inferior à dos materiais originais. Em Santa Catarina, a experiência do resgate de argamassas de cal está sendo divulgada com o projeto TERRACAL do IPHAN/SC.

Uma postura menos tradicionalista foi adotada por ANTELLINI (1990), que descreveu brevemente a sua experiência no restauro de duas importantes edificações de Roma: o 
Palácio de Firenze e a Igreja Santa Caterina de Funari. Este pesquisador utilizou um procedimento de restauro mesclando técnicas alternativas às originais.

No Palácio de Firenze parte do estuque encontrava-se aderido ao substrato, estando fixado por grampos, e parte havia sido perdida em desabamentos anteriores à intervenção. Como alternativas, optou-se por substituir os grampos das áreas não aderidas por consolidação com "vinapas" 3.4 e leite de cal. Na reconstituição do estuque foi utilizada argamassa de cal e pó de mármore, adicionando-se "Primal $A C 33^{3.5}$ " à pasta de cal. O acabamento foi feito com água destilada e "Primal AC 33" e, em algumas zonas, com pinturas aquarela.

$\mathrm{Na}$ Capela Ruissi da Igreja Santa Caterina de Funari o estuque fixado com pregos encontrava-se em perigo eminente de desabamento, devido à corrosão dos mesmos. Neste caso, optou-se pela consolidação por injeção da solução de “Ledan TB I" em água, adicionando-se às vezes o "Primal $A C 33$ ". Na região consolidada foram inseridos pontos de ancoragem com resina e em objetos maiores foram introduzidas armaduras. Na Capela Torres a armação do estuque também se encontrava corroída, com perdas por desabamento, tendo sido ainda observada a ocorrência de intervenções com cimento branco. Neste caso foi utilizada argamassa de cal, pozolana, gluconato de sódio e "Primal AC 33" para a consolidação do estuque e a reconstituição das partes perdidas com materiais e técnica do estuque romano.

\footnotetext{
${ }^{3.4}$ Tradução não encontrada.

${ }^{3.5}$ Cola à base de resina acrílica solúvel em água.
} 


\subsubsection{Argamassas de restauro}

ROSSI-DORIA (1990) apresentou os principais resultados do Workshop “Ancient mortars and mortars for restoration" organizado pela RILEM. Nesse evento grupos de trabalhos foram formados para discutir e elaborar:

- glossário técnico; e

- procedimentos para caracterização de argamassas de restauração.

ROSSI-DORIA (1986) já havia criticado o uso indiscriminado de produtos pouco conhecidos sem avaliação prévia e citou alguns aspectos que devem ser considerados na avaliação de argamassas de restauro, quando argamassas tradicionais de cal e areia não forem adequadas, seja pela trabalhabilidade, seja pelo tempo necessário para a carbonatação. Além das propriedades mecânicas, foram consideradas características importantes de serem avaliadas: o teor de sais solúveis, a distribuição de poros, a absorção de água por capilaridade, a permeabilidade ao vapor de água, a dureza superficial e o aspecto estético (cor).

Nos artigos citados, o pesquisador ressaltou a importância de avaliar as argamassas de restauro após seu envelhecimento acelerado, levantando a questão sobre o pouco conhecimento da interação dos agentes de deterioração e a dificuldade de simular em laboratório o envelhecimento natural.

MARTINEZ-RAMIREZ et al. (1995) avaliaram a adição de pentaclorofenol $\left(\mathrm{Cl}_{5} \mathrm{C}_{6} \mathrm{OH}\right)$ e de sepiolita $\left.\left.\left(\mathrm{Si}_{12} \mathrm{Mg}_{8} \mathrm{O}_{30}(\mathrm{OH})_{4}\right) \mathrm{H}_{2} \mathrm{O}\right)_{4} 12 \mathrm{H}_{2} \mathrm{O}\right)$ em argamassa de cal para recuperação de obras do Patrimônio Histórico e Artístico da Espanha. A primeira foi utilizada como biocida e a segunda para servir como suporte para a primeira, pois a capacidade de absorção e adsorção dessa argila foi considerada responsável por manter o biocida na argamassa por mais tempo. O material foi submetido a ciclos de gelo - degelo e a ciclos de imersão e secagem, utilizando soluções de cloreto de sódio $\left(35,7 \mathrm{~g} \mathrm{NaCl} / 100 \mathrm{cc} \mathrm{H}_{2} \mathrm{O}\right)$ 
e de sulfato de sódio $\left(7,25 \mathrm{~g} \mathrm{Na}_{2} \mathrm{SO}_{4} \quad 10 \mathrm{H}_{2} \mathrm{O} / 100 \mathrm{cc} \mathrm{H}_{2} \mathrm{O}\right)$. A influência dos ciclos de imersão nas soluções salinas e secagem foi avaliada por perda de massa, determinação da resistência à compressão, porosidade acessível à água e densidade aparente. As argamassas com a adição dos materiais mencionados não sofreram alteração significativa das propriedades e características determinadas, quando comparadas às argamassas de cal sem as adições, mesmo após os ciclos a que foram submetidas. 


\section{METODOLOGIA EMPREGADA NO ESTUDO DO FORRO EM}

\section{ESTUQUE DA EDIFICAÇÃO VILA PENTEADO}

A Figura 4.1 apresenta de forma esquemática as etapas desta pesquisa.

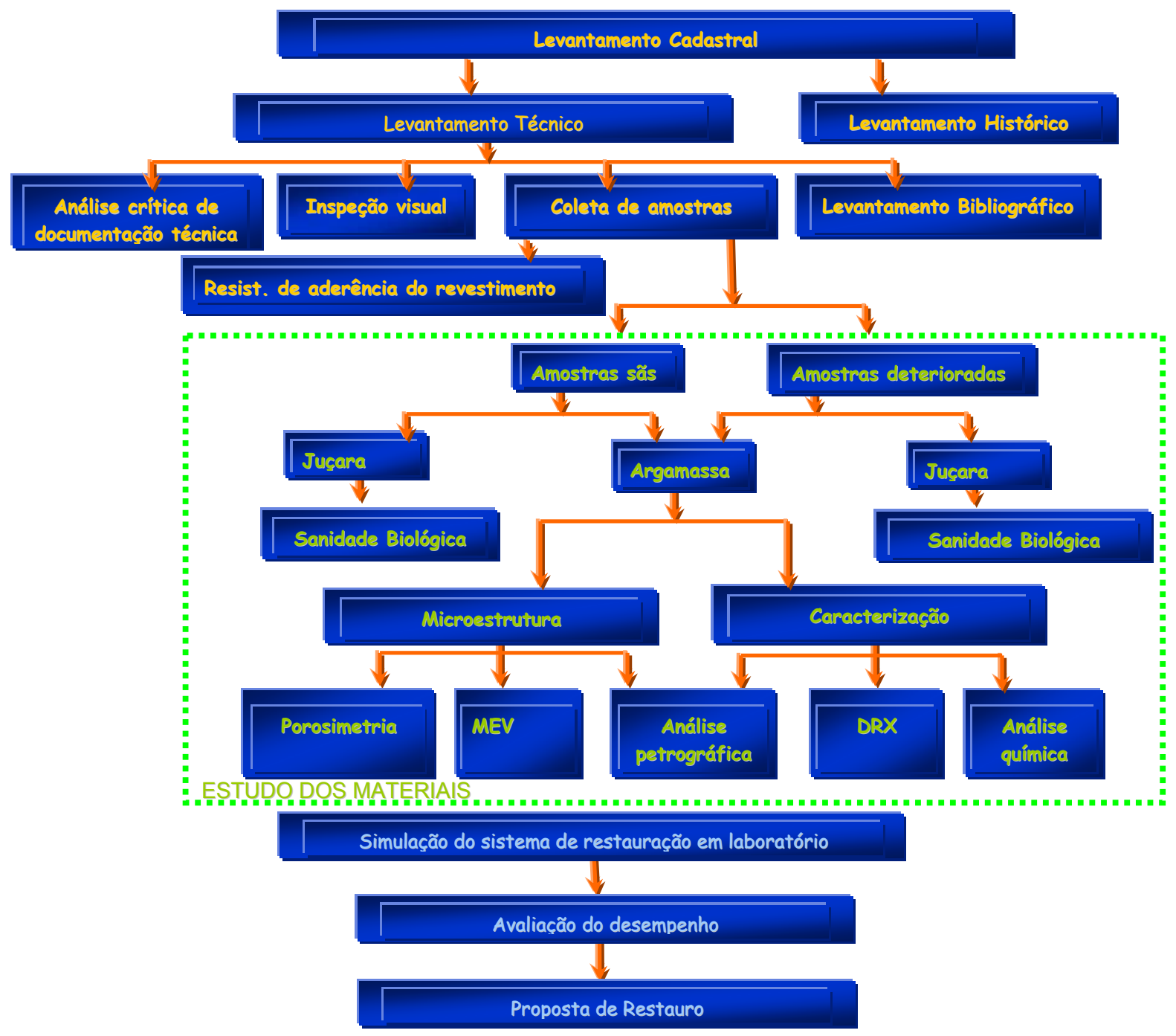

Figura 4.1 - Etapas do estudo do forro em estuque da edificação Vila Penteado 


\subsection{Levantamento cadastral (informações históricas e técnicas sobre a edificação)}

O Levantamento Cadastral da edificação foi realizado a partir da consulta à pesquisa coordenada pela Profa. Maria Cecília Nacléreo Homem Prado, realizada em 1976, por ocasião da solicitação do tombamento da edificação, seguida da consulta a documentos da Diretoria da FAUUSP. Nesta etapa, foi realizada também uma inspeção visual preliminar na edificação no primeiro semestre de 1997. Esta vistoria resultou num Relatório que descreveu o estado de conservação do forro em estuque da edificação, entregue à FAUUSP ao final daquele ano. As principais informações obtidas nesta vistoria foram transcritas no item 5 e Anexo $\boldsymbol{A}$ desta Dissertação e as fotos constam do Anexo D.

\subsection{Levantamento bibliográfico}

O levantamento bibliográfico procurou reunir informações de modo a possibilitar o conhecimento do estado da arte quanto aos princípios de restauro, à técnica construtiva de forro em estuque, às técnicas de investigação de argamassas antigas e a estudos de caso de restauro de forros em estuque.

As informações apresentadas sobre princípios de restauro, capítulos 1 e 2 , foram coletadas fundamentalmente da BS 7913 "Guide to the principles of the conservation of historic buildings" (BSI, 1998), complementada por informações obtidas em publicações específicas do tema.

O levantamento sobre a técnica construtiva de forro em estuque foi realizado por consulta aos manuais de construção do final do século XIX e início do XX, destacandose RAMÉE (1875), RAINVILLE (1880), LEITÃO (1896) e SEGURADO (1936). 
Ressalta-se também o trabalho de VARGAS (1994), publicação que apresenta abordagem histórica das técnicas construtivas.

Quanto às técnicas de investigação de materiais, enfocou-se a argamassa. Foram utilizadas em grande parte publicações da década de 90, por apresentarem investigações com enfoque técnico-científico. As publicações consideradas principais foram citadas no quadro resumo no Anexo $C$.

Os estudos de caso de restauro de forros em estuque foram obtidos principalmente em Anais de Congresso, das décadas de 80 e 90, tendo-se recorrido também à rede internacional de computadores - Internet.

\subsection{Estudo dos materiais empregados}

Em junho de 1998 foram coletadas amostras dos materiais utilizados no sistema de forro (argamassa e ripas de juçara) para análises em laboratório.

\subsubsection{Amostragem}

A amostragem teve como diretrizes:

a) permitir a avaliação do estado de conservação dos materiais empregados (argamassa e ripas de juçara) no forro em estuque;

b) conhecer as características dos materiais, visando o restauro do forro em estuque (reconstituição da argamassa e necessidade de tratamento preventivo contra o ataque de fungos nas ripas de juçara);

c) levantar hipóteses sobre o mecanismo de deterioração dos materiais;

As Figuras 4.2 e 4.3 mostram os locais de coleta das amostras, identificando ainda a abrangência do forro em estuque e do forro em madeira. Tomou-se como referência para definir os locais de coleta de amostras o mapeamento de pinturas murais realizado 
pela Arq. Regina Tirello em 1994 (do arquivo da FAUUSP), visando não danificar as pinturas de valor artístico.

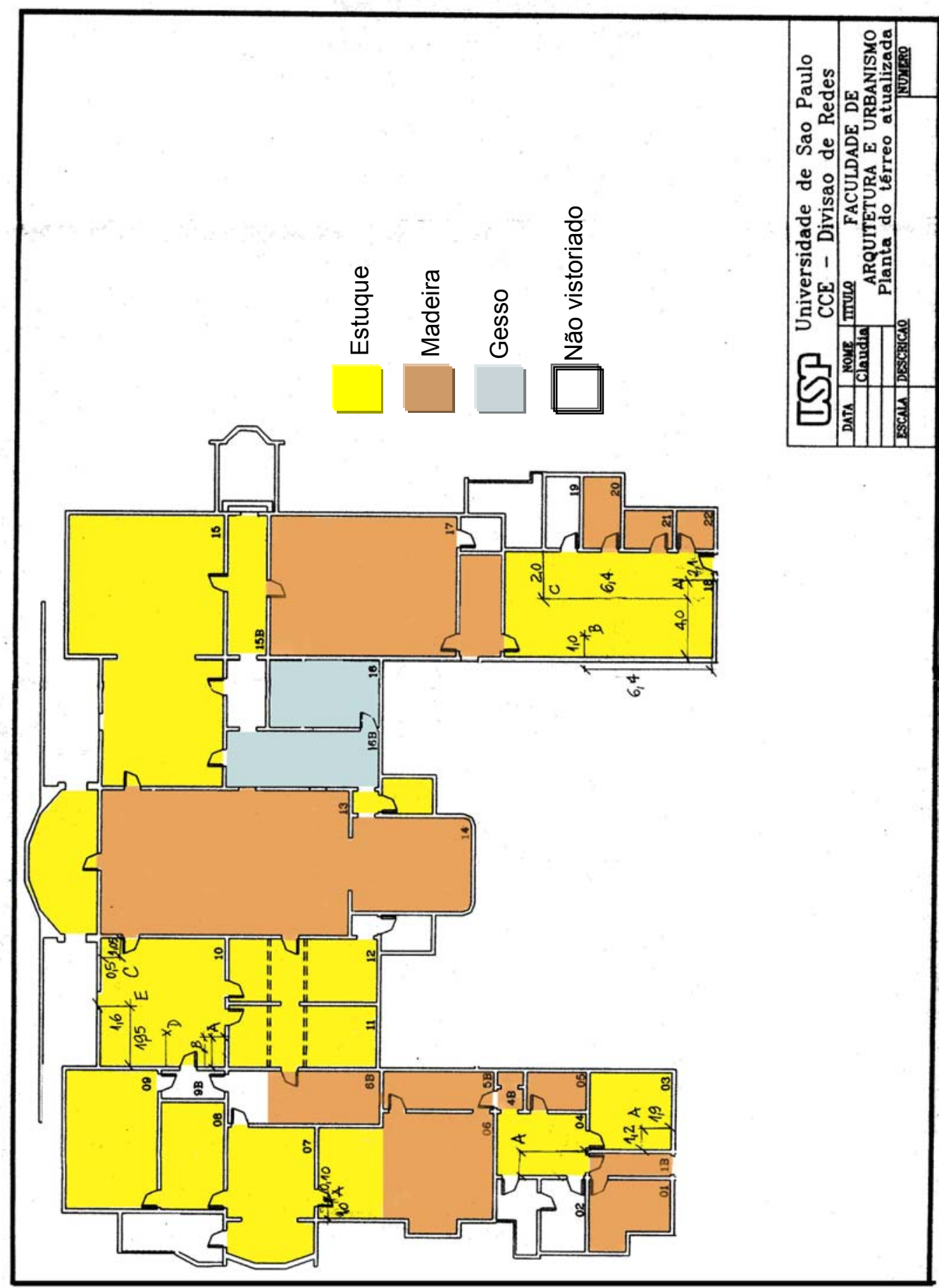

Figura 4.2 - Distribuição dos pontos de coleta de amostra - Pavimento Térreo. 


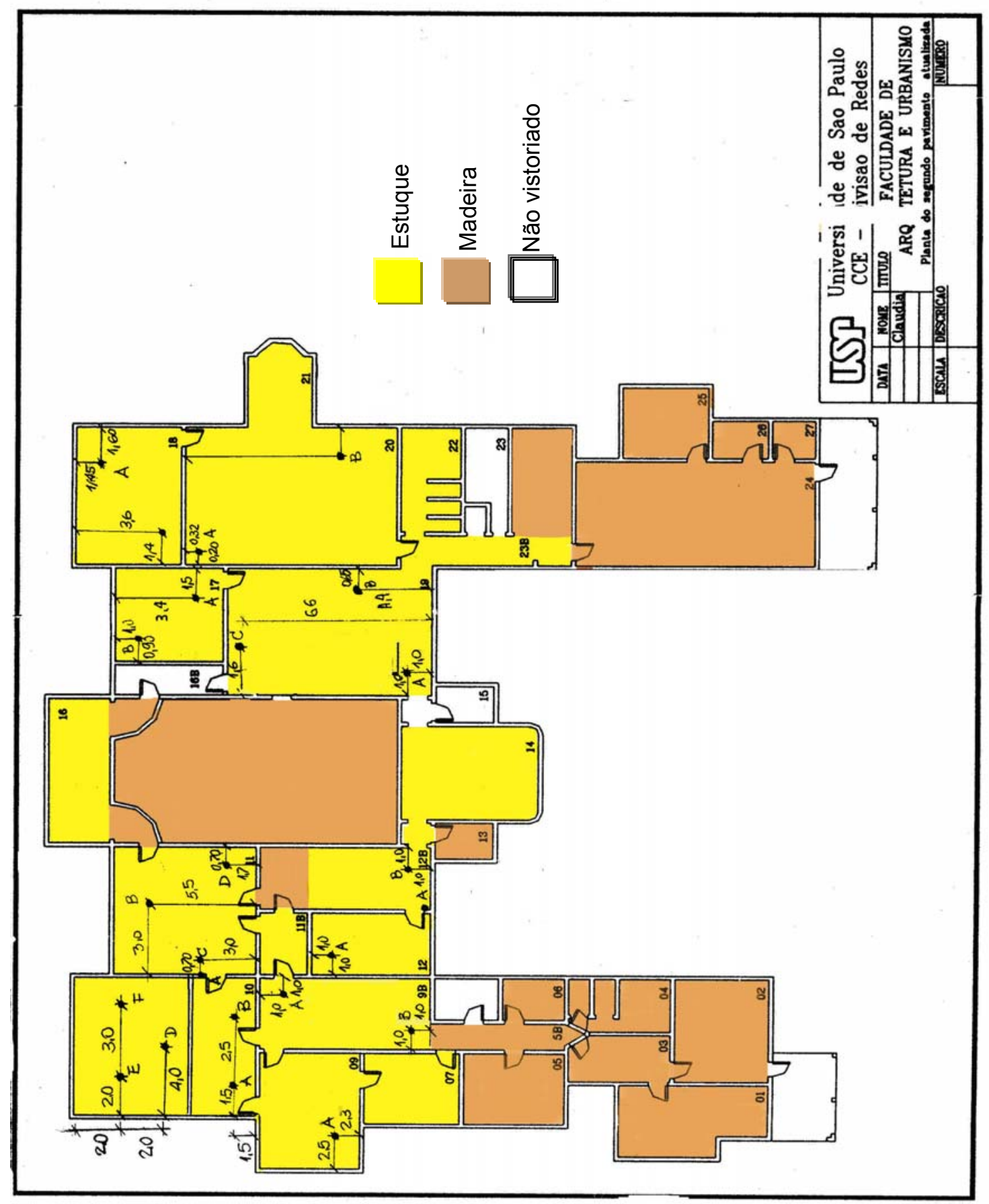

Figura 4.3 - Distribuição dos pontos de coleta de amostra - Pavimento Superior 
Coletou-se amostras em todas as regiões onde foram observados indícios de deterioração. Nas regiões aparentemente sãs, as amostras foram coletadas aleatoriamente. A Tabela 4-1 apresenta o critério utilizado para diferenciar as regiões sãs das deterioradas.

Tabela 4- 1 Características distintivas entre regiões sãs e deterioradas

\begin{tabular}{c|c|c}
\hline Componentes do Estuque & \multicolumn{2}{|c}{ Aspectos Observados } \\
\cline { 2 - 3 } & Regiões sãs & Regiões deterioradas \\
\hline \hline \multirow{2}{*}{ Juçara } & Íntegra & Desfibrada \\
& Aspecto inalterado & Apodrecida \\
& Pusência de pontos de cor & Pontos de cor \\
& escura & escura \\
& Dificuldade de corte & Baixa resistência ao \\
& Íntegra & corte \\
\hline \multirow{2}{*}{ Argamassa } & Aspecto inalterado & Pontuações de cor \\
& Cor esbranquiçada & Cor esbranquiçada \\
& Friável & Friável \\
\hline \hline
\end{tabular}

No pavimento térreo todas as amostras de argamassa foram coletadas na camada sob as ripas de juçara, ou seja, pela face do forro exposta aos usuários do prédio. No pavimento superior, a maioria das amostras de argamassa foi coletada na camada sobre as ripas de juçara, acessíveis pelo sótão ${ }^{4.1}$.Visando avaliar a semelhança entre a natureza dos

${ }^{4.1}$ Inicialmente o plano de amostragem previa a coleta de amostras de argamassa somente na camada sob as ripas de juçara, uma vez que esta foi considerada a de maior interesse por ter a função de suporte das pinturas murais. Por solicitação do Administrador da edificação, Prof. Carlos Fagin, e da Coordenadora do canteiro-escola do Programa de Formação de Restauradores em Pinturas Murais, Arq. Regina Tirello, a maioria das amostras do pavimento superior foi coletada pelo sótão, ou seja, na camada superior de argamassa. Por ficar oculta, esta amostragem possibilitou aumentar o tamanho das amostras, facilitando a avaliação do estado de deterioração da juçara por ter maior área exposta. 
materiais constituintes das argamassas que envolvem as ripas de juçara de suporte do forro em estuque, no cômodo $\mathrm{S} 10^{4.2}$ foram coletadas amostras nas duas camadas de argamassa e submetidas à análise por difração de raios X.

O número de amostras coletadas no forro do pavimento térreo e o tamanho das mesmas foram bem inferiores aos das amostras coletadas no forro do pavimento superior, pelo sótão, de modo a causar a mínima interferência na edificação.

Todas as amostras de argamassa destinadas à análise de sanidade biológica foram coletadas da camada sob as ripas de juçara, para evitar a contaminação da amostra com a poeira acumulada e impregnada sobre a camada de argamassa acessível pelo sótão.

No cômodo T10, local onde ocorreu o desabamento em 1994 e que na ocasião da coleta de amostras ainda não havia sido reparado, foram coletadas quatro amostras para avaliar a amplitude do efeito da biodeterioração do forro.

\subsubsection{Identificação das amostras}

As amostras de argamassa foram identificadas com 4 ou 5 caracteres.

Os três ou quatro primeiros caracteres referem-se ao cômodo no qual foi coletada a amostra (mesma identificação apresentada nas Figuras 4.2 e 4.3 );

Nas áreas de circulação, a identificação do cômodo é acompanhada pela letra B (por exemplo, o hall do cômodo S12 foi identificado como S12B). Nestes casos a identificação da amostra tem cinco caracteres;

O último caracter refere-se à posição de retirada da amostra (Figuras 4.2 e 4.3).

Na Tabela 4-2 são apresentados dois exemplos de identificação das amostras.

${ }^{4.2}$ As Figuras 4.2 e 4.3 apresentam a identificação das salas utilizada nesta pesquisa e as Tabelas A-2 e A-3 do Anexo $\boldsymbol{A}$ - Levantamento cadastral da edificação apresentam a relação entre identificação dos cômodos utilizada nesta pesquisa e os números utilizados na identificação da FAU. 
Tabela 4-2 Identificação e localização das amostras

\begin{tabular}{l|l}
\hline \multicolumn{1}{c|}{ Identificação } & Localização das amostras \\
\hline \hline T18C & $\begin{array}{l}\text { Pavimento Térreo } \\
\text { Cômodo 18 (sala de aula) } \\
\text { Ponto C }\end{array}$ \\
\hline S12BA & $\begin{array}{l}\text { Pavimento Superior } \\
\text { Cômodo 12B (área de } \\
\text { circulação) } \\
\text { Ponto A (em cima da porta para } \\
\text { a sala do diretor) }\end{array}$ \\
\hline \hline
\end{tabular}

As amostras de juçara foram identificadas pelo sistema de código descrito acima acrescido no final pela letra minúscula $\mathrm{j} .{ }^{4.3}$

\subsubsection{Procedimento de coleta}

Foram definidos três procedimentos de coleta de amostras de argamassa devido às condições de acessibilidade e para evitar a contaminação das mesmas. Os procedimentos estão apresentados nas Figuras 4.4 a 4.6, tendo sido necessárias pequenas adequações para algumas amostras. As amostras destinadas à análise de sanidade biológica foram denominadas amostras especiais.

A atividade de coleta de amostras foi realizada com auxílio de um técnico em edificações do CPqDCC - Centro de Pesquisa do Departamento de Construção Civil da EPUSP. Algumas etapas da coleta de amostras foram documentadas por fotografias, dentre as quais selecionaram-se as Figuras 4.7 a 4.9.

${ }^{4.3}$ A título de curiosidade uma amostra de madeira foi coletada na região do desabamento em 1994 e identificada acrescendo no seu final a letra minúscula m (T10Dm). Essa amostra foi submetida à avaliação de sanidade biológica, assim como as amostras de juçara deterioradas. 
Procedimento A

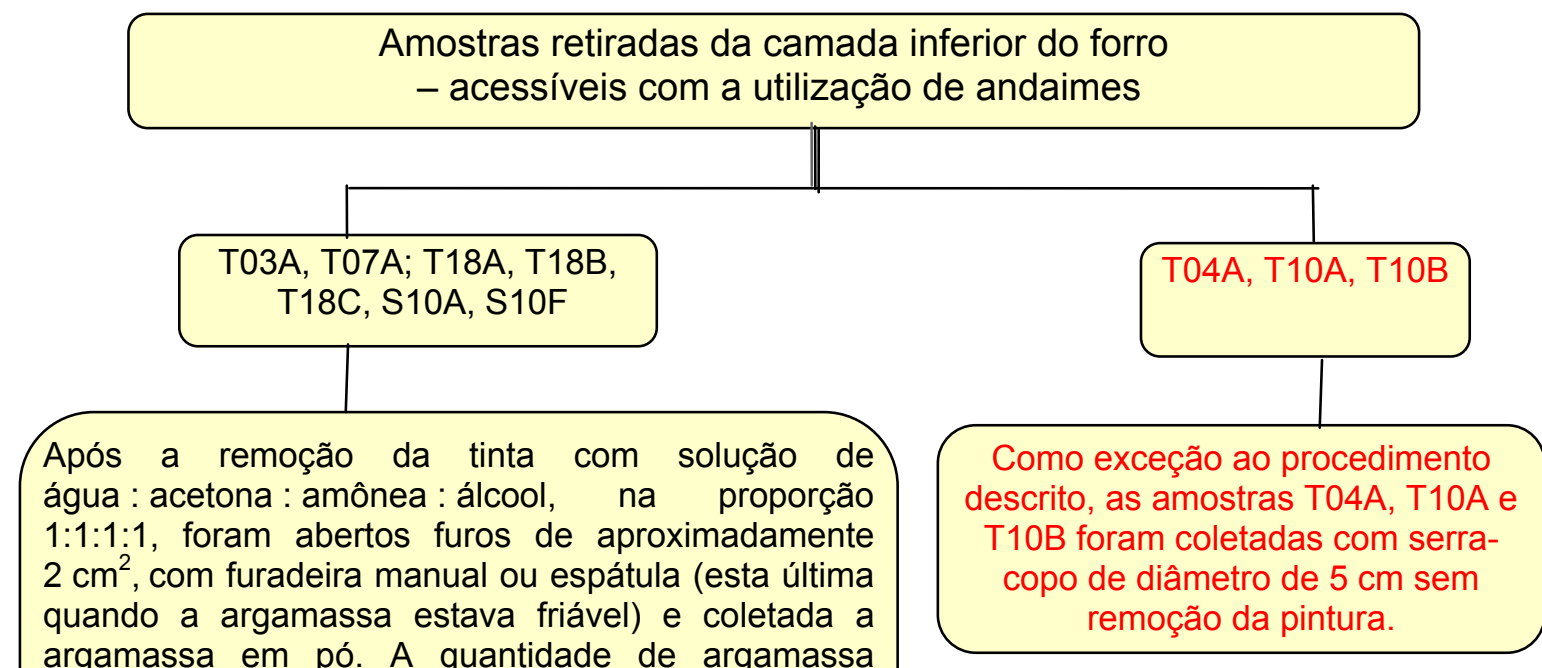

Figura 4.4 - Diagrama de bloco do procedimento de coleta de amostras A.

Procedimento $B$

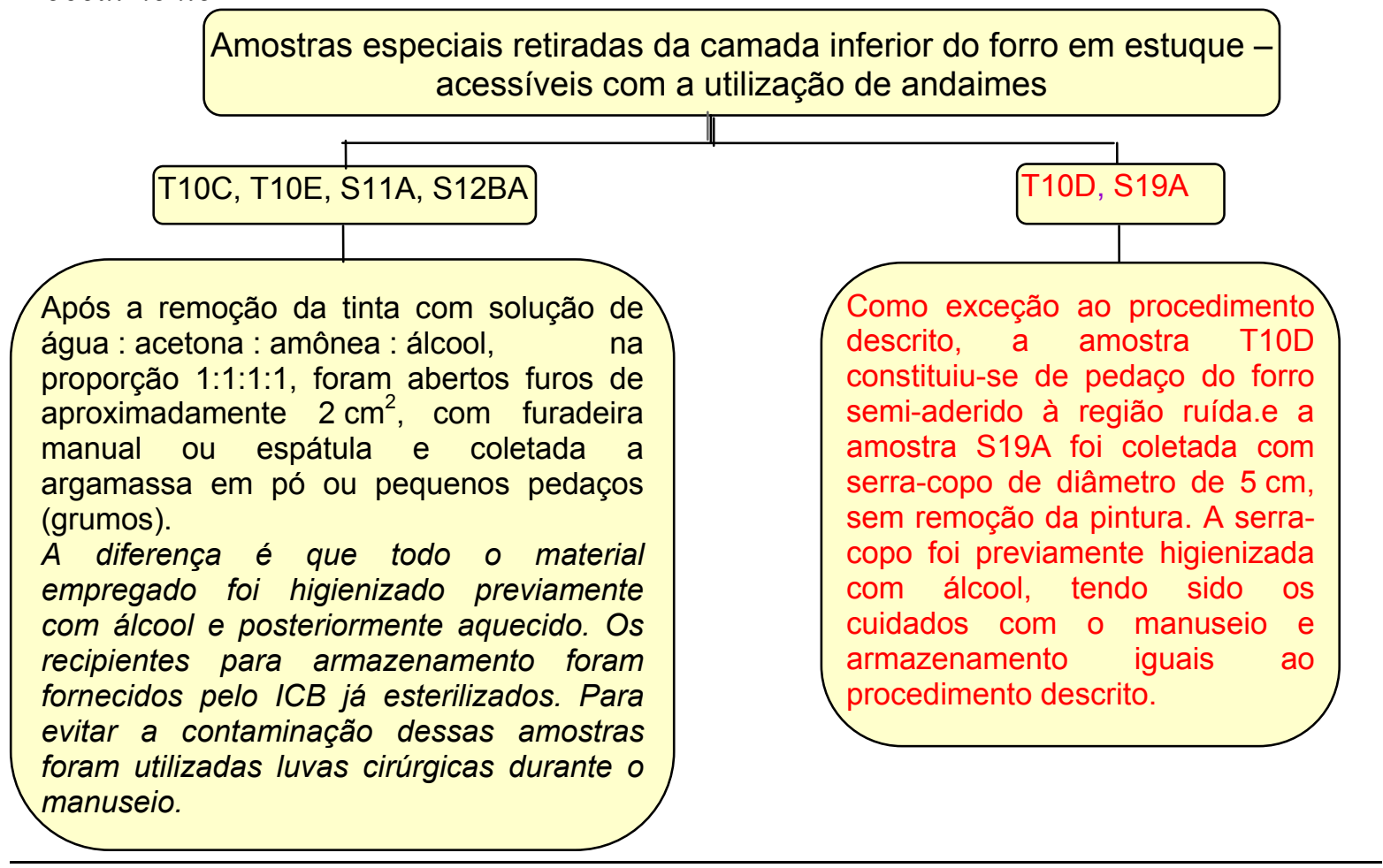

Figura 4.5 - Diagrama de bloco do procedimento de coleta de amostras B. 
Nota: A coleta destas amostras foi orientada e acompanhada pela pesquisadora Márcia Aiko Shirakawa, que desenvolveu sua tese de doutorado Biodeterioração de argamassas por fungos: desenvolvimento de teste acelerado para avaliação da bio-receptividade (ICB/EPUSP) e que orientou os ensaios realizados no ICB (Instituto de Ciências Biomédicas da USP).

\section{Procedimento $C$}

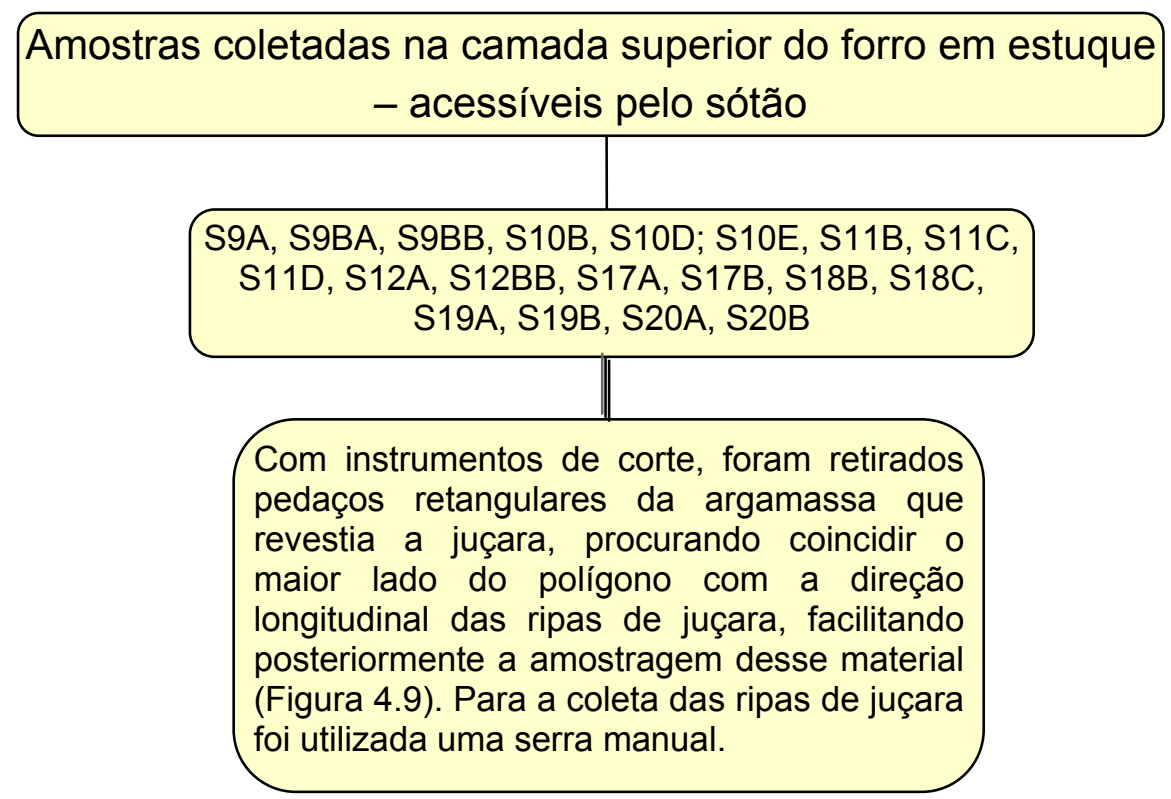

Figura 4.6 - Diagrama de bloco do procedimento de coleta de amostras C.

As Figuras 4.7 e 4.8 ilustram a região de coleta da amostra S19A e seu procedimento de coleta, respectivamente.
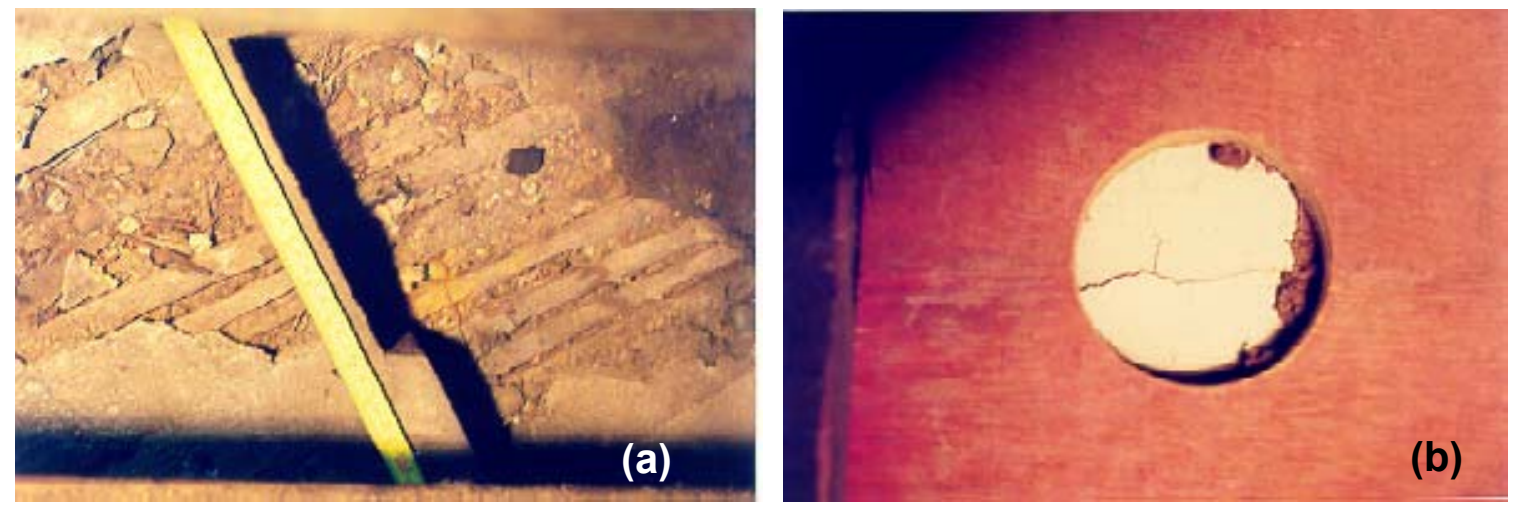

Figura 4.7 - Local de coleta da amostra S19A. Região bastante deteriorada embaixo da viga metálica. (a) Vista pelo sótão; (b) Vista pelo hall superior (S19), ante-sala da secretaria, após corte da placa de madeirite (em vermelho) com serra-copo de $50 \mathrm{~mm}$ de diâmetro vide Figura 4.8. 

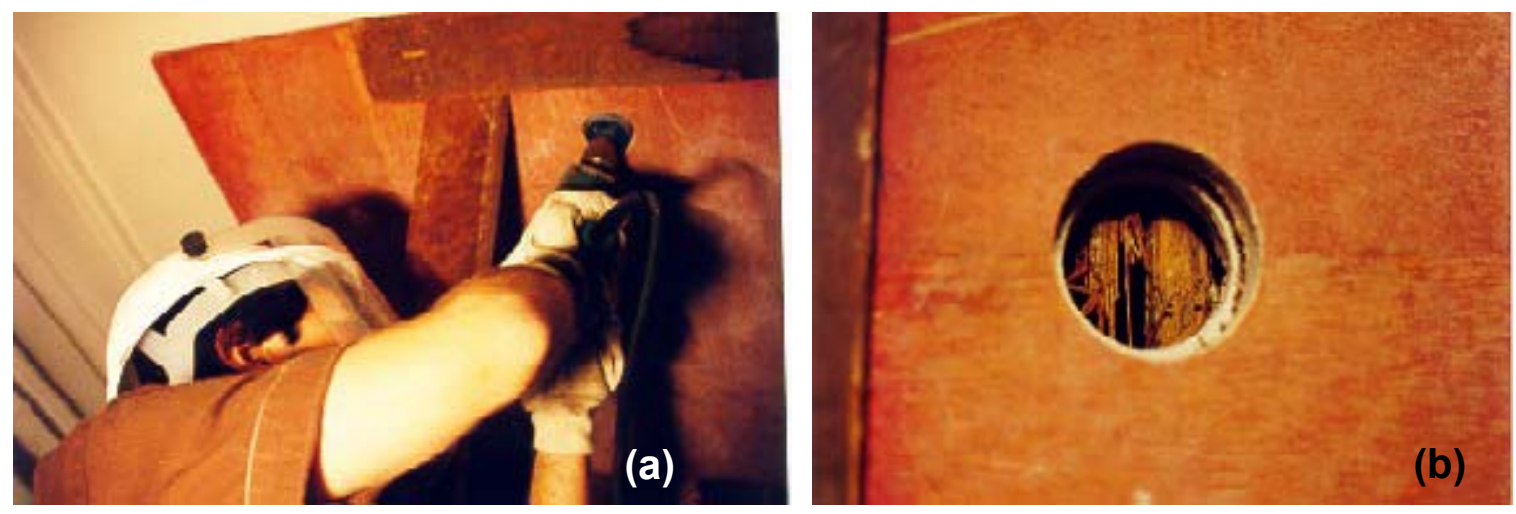

Figura 4.8 - Procedimento de coleta da amostra S19A; (a) corte com serra-copo; (b) detalhe da ripa de juçara bastante deteriorada e sem nenhum resquício de argamassa evidenciando nenhuma aderência entre esses materiais.

A Figura 4.9 ilustra o procedimento de coleta pelo sótão.
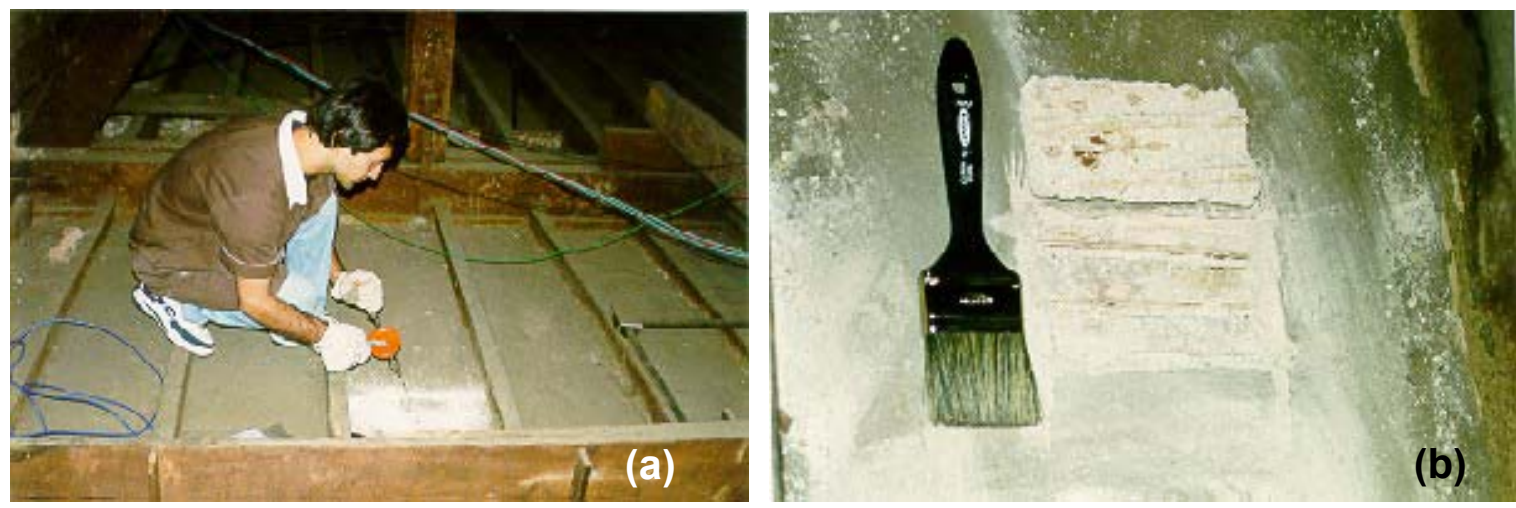

Figura 4.9 - Coleta de amostras retiradas na camada superior do forro em estuque - acesso pelo sótão (S20B). (a) corte furadeira manual; (b) detalhe da ripa de juçara considerada íntegra nessa região. A facilidade para destacamento da argamassa denotou a baixa aderência às ripas de juçara.

Imediatamente após a coleta, as amostras foram armazenadas em sacos plásticos fechados, exceto as destinadas à análise de sanidade biológica que foram colocadas em recipientes específicos. As amostras de argamassa foram armazenadas independentes das amostras de juçara. 


\subsubsection{Seleção das amostras a serem analisadas}

A seleção das amostras de argamassa objetivou possibilitar a avaliação da uniformidade do estuque, caracterização de amostras de referência e avaliação da biodeterioração. Esta última também avaliada nas amostras de juçara. A Figura 4.10 apresenta as análises realizadas em laboratórios e as amostras selecionadas para cada análise. As demais amostras não foram analisadas por se entender que as informações que seriam obtidas não justificariam o custo.

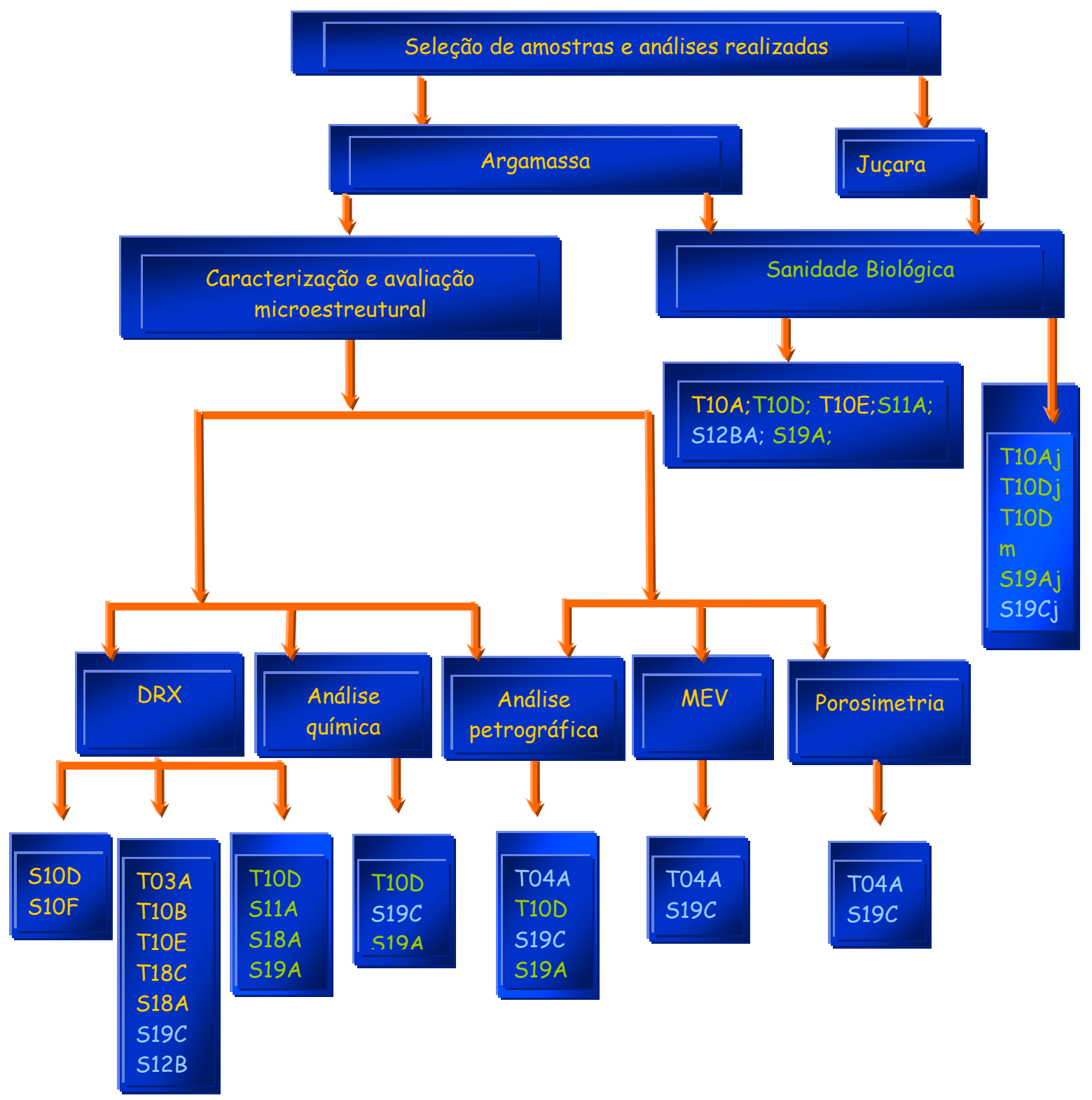

Figura 4. 10 - Seleção de amostras e análises realizadas. 


\section{Avaliação da uniformidade da argamassa}

As amostras de argamassa T03A, T10B, T10D, T10E, T18C, S10D, S10F, S11A, S12BA, S18A, S19A, S19C foram destinadas à análise por difração de raios-X para a determinação da composição mineralógica, avaliando qualitativamente a uniformidade entre elas.

As amostras S10D e S10F foram analisadas visando avaliar comparativamente possíveis variações entre os constituintes das duas camadas de argamassa que envolvem as ripas de juçara.

A análise comparativa entre as amostras do cômodo T10 objetivou avaliar os efeitos da biodeterioração.

\section{Caracterização de amostras de argamassa de referência}

As amostras S19C e T04A foram consideradas como amostras de referência, uma vez que se encontravam em regiões aparentemente sãs.

$\mathrm{Na}$ amostra S19C foram realizadas as análises química e petrográfica, além da observação por microscopia eletrônica de varredura e da porosimetria por intrusão de mercúrio. $\mathrm{Na}$ amostra T04A foram realizadas todas as análises anteriores, exceto a análise química, uma vez que não se dispunha de material suficiente para esta análise.

\section{$\underline{\text { Avaliação da biodeterioração }}$}

Nas amostras de argamassa T10A, T10D, T10E, S11A, S12BA, S19A foi realizado o isolamento e a identificação de fungos. A descrição dos locais de coleta de amostra é apresentada no Capítulo 6, referente à apresentação de resultados, para facilitar a interpretação. A amostra S12BA foi considerada como amostra de referência. 
As amostras T10D e S19A, coletadas em regiões com evidências de biodeterioração, foram observadas ao microscópio estereoscópico, sem tratamento prévio, para verificar a existência de alterações da argamassa na interface com as ripas de juçara.

A análise de sanidade biológica foi realizada nas amostras de juçara T10Aj, T10Dj, $\mathrm{S} 11 \mathrm{Aj}, \mathrm{S} 19 \mathrm{Aj}$ e S19Cj. Todas as amostras foram coletadas em regiões com indícios de biodeterioração, exceto a S19Cj, considerada como amostra de referência.

\subsubsection{Resistência de aderência do revestimento}

$\mathrm{Na}$ ocasião da coleta de amostras tentou-se realizar o ensaio de resistência de aderência do revestimento de acordo com o método da NBR 13.528 (ABNT, 1995), utilizando uma serra-copo com $50 \mathrm{~mm}$ de diâmetro. O revestimento encontrava-se bastante friável, perdendo material durante o corte, como mostra a Figura 4.11, o que inviabilizou a realização do ensaio por este procedimento.
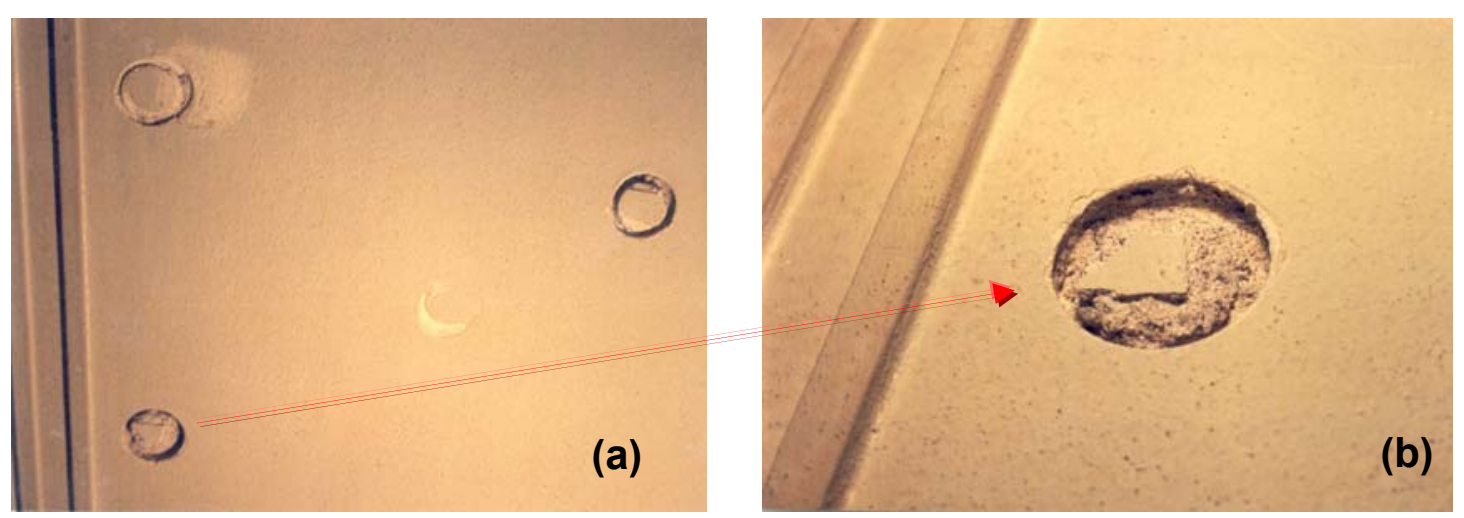

Figura 4.11 -Preparação para o ensaio de resistência de aderência do revestimento no cômodo T10 (mapoteca); (a) aspecto geral do revestimento cortado com serra-copo de $50 \mathrm{~mm}$ de diâmetro; (b) detalhe da desagregação da argamassa, inviabilizando a realização do ensaio. 


\subsubsection{Análise da argamassa em laboratório}

\subsubsection{Análise por difração de raios $X(D R X)$}

As amostras selecionadas para a difração de raios $\mathrm{X}$ foram analisadas no Laboratório de Caracterização Tecnológica do Departamento de Engenharia Mineral da EPUSP, tendo sido empregado um difratômetro Phillips, modelo PW1710, com radiação $\mathrm{K}_{\alpha}$ de cobre e avanço de $0,02 \%$.

A preparação das amostras consistiu da cominuição em almofariz, seguida da moagem em moinho de bolas e da conformação sobre o suporte da amostra.

A interpretação do espectrograma foi baseada nas fichas do JCPDS - Joint Committee on Powder Diffraction Standards, adquiridas no banco de dados do programa acoplado ao equipamento.

Tomou-se como referência para interpretação da análise por difração de raios X (DRX) os espectrogramas dos seguintes minerais: C-S-H, magnesita, dolomita, periclásio, brucita, calcita, portlandita, cal, gipso, quartzo, caulinita, montmorilonita, mica muscovita e microclínio. A Tabela 4- 3 apresenta o ângulo de ocorrência dos picos principais, com intensidade superior a $80 \%$.

Devido à grande amplitude dos picos do constituinte quartzo, a interpretação dos resultados da análise por difração de raios X foi bastante difícil. Procurando realçar os picos principais dos demais constituintes da argamassa, as amostras T10B, T18C, T03A, S19C e S18A sofreram beneficiamento, que consistiu na cominuição em almofariz sem quebrar os grãos de quartzo e posterior peneiramento, desprezando-se o material retido na peneira $\mathrm{ABNT}$ n. ${ }^{\circ}$ 50. O material passante seguiu para a moagem em moinho de bolas e conformação sobre o suporte da amostra. 
Tabela 4- 3 Ângulos de ocorrência dos picos dos espectros dos minerais comuns em argamassa

\begin{tabular}{l|l|l}
\hline \hline \multicolumn{1}{c|}{ Minerais } & $\begin{array}{l}\text { Intensidade } \\
\text { de pico }\end{array}$ & d A \\
\hline C-S-H & 100 & 3,07 \\
& 50 & 2,80 \\
& 50 & 1,83 \\
\hline magnesita & 100 & 2,74000 \\
\hline dolomita & 100 & 2,88800 \\
\hline periclásio & 100 & 2,10000 \\
\hline brucita & 80 & 1,48000 \\
\hline calcita & 100 & 2,36500 \\
\hline portlandita & 90 & 4,77000 \\
\hline cal livre & 100 & 3,03000 \\
\hline gipso & 100 & 2,62700 \\
& 100 & 1,69000 \\
& 80 & 2,39000 \\
\hline quartzo & 100 & 7,56000 \\
\hline caulinita & 100 & 4,27900 \\
& 100 & 2,87100 \\
& 90 & 4,28000 \\
\hline montmorilonita & 100 & 3,34200 \\
\hline mica muscovita & 100 & 4,60000 \\
\hline microclínio & 100 & 4,08000 \\
\hline & 80 & 7,40000 \\
& 80 & 3,59000 \\
\hline & 100 & 12,9000 \\
\hline & 100 & 4,50000 \\
& 85 & 9,91000 \\
\hline & 100 & 3,24400 \\
\hline & & \\
& & \\
& &
\end{tabular}

As amostras beneficiadas foram identificadas pela sigla alfanumérica similar à original e finalizada pela letra X, por exemplo T10X refere-se a T10B beneficiada.

As amostras T10B e T10X, S19C e S19X foram analisadas comparativamente, com o objetivo de verificar a influência do beneficiamento das amostras.

\subsubsection{Reconstituição da proporção aglomerante : agregado por análise química}

A análise química por via úmida foi realizada no Laboratório de Química de Materiais da Divisão de Engenharia Civil do IPT, de acordo com o Método IPT (QUARCIONI, 1998). Foi realizado posteriormente o cálculo para o proporcionamento 
da argamassa, ou seja, reconstituição da proporção aglomerante : agregado na base nãovolátil.

Como as características dos materiais originais não eram conhecidas, para o cálculo do proporcionamento de materiais da argamassa foi considerada como referência a composição de uma cal dolomítica, tipo CH III. O tipo de cal foi escolhido devido à proporção cálcio : magnésio indicada na análise química e à análise por difração de raios X ter detectado dolomito na amostra S19C.

$\mathrm{Na}$ reconstituição da proporção aglomerante : agregado, a partir dos dados da análise química, admitiu-se a utilização de cal virgem ${ }^{4.4}$ tendo em vista a prática da época, obtendo-se assim as proporções em massa (cal virgem : agregado quartzoso).

\subsubsection{Análise petrográfica}

A análise petrográfica foi realizada no Laboratório de Petrologia e Tecnologia de Rochas da Divisão de Geologia do IPT, tendo sido utilizados lupa estereoscópica Wild e microscópio petrográfico Carl Zeiss, dotado de câmara fotográfica.

A análise petrográfica foi iniciada com um exame visual do material, seguido de observação sob lupa binocular e finalizada com a observação ao microscópio óptico de luz polarizada através de uma lâmina delgada. As porcentagens relativas das fases foram estimadas visualmente e as medidas dos grãos foram obtidas com o auxílio de objetiva graduada.

Para preparação da seção a ser analisada ao microscópio óptico foi retirado um bloquete com dimensões aproximadas de $(40 \times 20 \times 10) \mathrm{mm}$ do testemunho de argamassa. Este

\footnotetext{
${ }^{4.4} \mathrm{Na}$ época, os fabricantes comercializavam cal virgem, resultante da calcinação do calcário ou do dolomito à temperatura de $800-900^{\circ} \mathrm{C}$, a qual era hidratada em obra antes do preparo da argamassa.
} 
bloquete foi impregnado a vácuo com uma resina tipo Araldite ${ }^{\circledR}$ e Oracet ${ }^{\circledR}$ (corante de cor azul), para distinguir os vazios presentes na amostra dos danos devido à preparação da lâmina. Por desgaste do bloquete colado em lâmina de vidro obteve-se seção delgada com espessura final de $30 \mu \mathrm{m}$, coberta posteriormente com uma lamínula.

\subsubsection{Observações da microestrutura por microscopia eletrônica de varredura (MEV)}

A análise por microscopia eletrônica de varredura foi realizada no Laboratório de Tecnologia Cerâmica da Divisão de Química do IPT. As amostras de argamassa foram estudadas em superfícies de fratura secas em estufa a $110^{\circ} \mathrm{C}$, por no mínimo 12 horas. Após montagem em base de latão com tinta de grafite, as amostras foram metalizadas com ouro e analisadas ao microscópio eletrônico de varredura Jeol 6300. A energia de aceleração empregada foi de $20 \mathrm{kV}$.

\subsubsection{Porosimetria por intrusão de mercúrio}

A análise de porosimetria por intrusão de mercúrio foi realizada no Laboratório de Caracterização Física dos Materiais da Divisão de Química do IPT. Para a quantificação da porosidade e determinação da distribuição do diâmetro de poros, foram ensaiados corpos-de-prova cúbicos de $1 \mathrm{~cm}^{3}$, utilizando-se o porosímetro Micromeritics, modelo Autopore III e picnômetro de hélio Micromeritics, modelo Accupyc 1330.

\subsubsection{Isolamento e identificação de fungos}

O isolamento e identificação dos fungos presentes nas amostras de argamassa foram realizados no Instituto de Ciências Biomédicas - ICB/USP, segundo o método descrito por SHIRAKAWA (1999). Além da identificação dos fungos, foi realizada uma análise 
quantitativa, cujos resultados foram expressos em unidades formadoras de colônia (UFC). Estes resultados não foram analisados, mas registrados para comparação em estudos futuros. Junto aos resultados está apresentada a descrição do local de coleta das amostras.

\subsubsection{Sanidade biológica das ripas de juçara}

A análise de sanidade biológica das amostras de juçara foi realizada no Laboratório de Micologia da Divisão de Produtos Florestais do IPT utilizando procedimento interno.

O exame de sanidade biológica iniciou com uma análise visual macroscópica, seguida de análise microscópica de lâminas histológicas, no sentido transversal das ripas, para verificar a presença ou não de estruturas de fungos.

Para observação das amostras utilizando microscópio óptico Carl Zeiss, sob luz difusa, foram montadas lâminas histológicas de cortes com espessuras entre 15 e $20 \mu \mathrm{m}$ ao natural e corados.

Houve bastante dificuldade na preparação das lâminas histológicas, devido à dureza da juçara e ao grau de apodrecimento no qual algumas amostras se encontravam.

\subsubsection{Simulação do sistema de restauro do forro em estuque da edificação Vila Penteado}

A partir dos ensaios de caracterização das amostras sãs, da avaliação das amostras deterioradas e da revisão bibliográfica, foi elaborada uma proposta de intervenção, simulada no Laboratório de Concreto da Divisão de Engenharia Civil do IPT para avaliação do seu desempenho. Para tanto, foi retirado com disco de corte um testemunho do forro original do cômodo $\mathrm{S} 19$, tendo este testemunho área de aproximadamente $40 \times 40 \mathrm{~cm}^{2}$.

As etapas para a simulação da proposta de intervenção foram: 
a) remoção da camada de argamassa sobre as ripas de juçara;

b) remoção das ripas de juçara deterioradas;

c) limpeza das ripas de juçara remanescentes com escova de aço e pano úmido;

d) aplicação de solução de cal (água de cal), adotando como referência a proposta de PETERSON $(1981)^{4.5}$;

e) sazonamento do testemunho em câmara de carbonatação acelerada com $6 \%$ de $\mathrm{CO}_{2}$ por 30 dias, para carbonatação da solução de cal e consolidação da argamassa original;

f) preenchimento das lacunas deixadas pela remoção das ripas de juçara deterioradas com argamassa de cal e aplicação de uma fina camada (aproximadamente $5 \mathrm{~mm}$ ) sob as demais ripas;

g) posicionamento da tela metálica deployé;

h) aplicação da argamassa de cal (aproximadamente $10 \mathrm{~mm}$ );

i) sazonamento do testemunho em câmara de carbonatação acelerada com $6 \%$ de $\mathrm{CO}_{2}$ por 30 dias, para carbonatação da $\operatorname{argamassa~}^{4.6} \mathrm{e}$;

${ }^{4.5}$ O método proposto por PETERSON (1981) para consolidação de revestimentos de argamassa e pinturas murais foi avaliado mantendo um pequeno testemunho após a aplicação da solução em câmara de carbonatação acelerada com concentração de $\mathrm{CO}_{2}$ de $6 \%$ e posteriormente verificado visualmente quanto a indícios de formação de carbonato de cálcio sobre a superfície com pintura. Nenhuma ocorrência foi verificada, concluindo-se, portanto, que não haveria prejuízo às pinturas murais da edificação.

${ }^{4.6}$ Optou-se pela carbonatação acelerada para garantir completa carbonatação antes de submeter o corpode-prova aos ciclos de variação de temperatura. O teor de $\mathrm{CO}_{2}$ da câmara de carbonatação foi de $6 \%$, geralmente utilizado em ensaios acelerados. 
j) acompanhamento da evolução da carbonatação com o indicador fenolftaleína em testemunho de aproximadamente $170 \mathrm{~cm}^{2}$, reparado em paralelo.

\section{Preparação e aplicação da solução de cal ${ }^{4.7}$}

Para a preparação da solução de cal foi utilizada uma cal cálcica tipo CH I. Cales cálcicas possuem maior teor de $\mathrm{CaO}$ que cales dolomíticas ou magnesianas, o que propicia uma reação de carbonatação mais rápida.

Adotou-se a proporção de cal : água $1: 8$ em volume (1:7,8, em massa), uma vez que constatou-se que a proporção resultava em solução saturada de cal.

As etapas da preparação e aplicação da solução de cal foram:

a) mistura da água e cal em argamassadeira de bancada por 2 min;

b) acondicionamento da suspensão em recipiente plástico por aproximadamente $24 \mathrm{~h}$, para decantação do sólido;

c) coleta da solução sobrenadante por sifonamento, sem misturar com a cal decantada e;

d) aplicação da solução de cal na camada a consolidar, vertendo-a sobre a argamassa entre as ripas, ou exposta pela remoção das ripas deterioradas até a observação de indícios de umedecimento na superfície da face inferior do forro.

A quantidade de solução aplicada foi $634 \mathrm{~g}$ na primeira aplicação e $345 \mathrm{~g}$ na segunda aplicação. Entre uma aplicação e outra foi dado um intervalo de quatro dias.

\section{Preparação e aplicação da argamassa}

A proporção cal : areia, obtida com a análise química da argamassa original, foi convertida considerando a utilização de cal hidratada, freqüentemente encontrada na

4.7 Segundo GUIMARÃES (1989) solução de cal pode também ser denominada por água de cal e corresponde à solução aquosa pura, saturada ou não, de hidróxidos de cálcio ou hidróxidos de magnésio, sem qualquer partícula de cal hidratada em suspensão. 
cidade de São Paulo, tendo sido a argamassa de restauro dosada na proporção $1: 4,7 \mathrm{em}$ massa. Para a preparação da argamassa utilizou-se uma cal dolomítica tipo CH III.

O teor de água foi ajustado para argamassa de consistência normal conforme procedimento da NBR 13.276 (ABNT, 1995).

A argamassa de cal foi colocada preenchendo os vazios decorrentes da remoção das ripas deterioradas e formando uma fina camada sobre as demais ripas. A tela deployé foi colocada sobre esta camada e, posteriormente, coberta com nova camada de argamassa. A quantidade de argamassa aplicada foi $5985 \mathrm{~g}$.

O corpo-de-prova ficou 30 dias na câmara de carbonatação.

\subsubsection{Avaliação do desempenho do sistema de restauro}

A avaliação da compatibilidade térmica dos materiais originais e novos, quando submetidos a ciclos de aquecimento e resfriamento, foi utilizada como indicador de desempenho do método de restauro.

O corpo-de-prova foi submetido a 10 ciclos de aquecimento e resfriamento. O corpo-deprova permaneceu em estufa ventilada a $60^{\circ} \mathrm{C}$ por $24 \mathrm{~h}$ e em seguida em condições de ambiente de laboratório por no mínimo $24 \mathrm{~h}$. O corpo-de-prova foi avaliado visualmente e pela determinação de resistência de aderência do sistema.

\section{Avaliação visual}

Foram realizadas avaliações visuais antes do corpo-de-prova ser submetido aos ciclos térmicos e após cada ciclo. As alterações no decorrer do ensaio e as anomalias observadas foram descritas. 


\section{Determinação da resistência de aderência do sistema}

A resistência de aderência do sistema foi determinada após o quinto e o décimo ciclo térmico.

Após o quinto ciclo térmico foram cortadas, com disco de corte, duas faixas nas extremidades do corpo-de-prova de $400 \times 400 \mathrm{~mm}^{2}$ no sentido longitudinal às ripas de juçara e com largura aproximada de $70 \mathrm{~mm}$. Dessas faixas foram preparados os corposde-prova - quadrados com $50 \mathrm{~mm}$ de lado - para o ensaio de resistência de aderência do sistema. Os corpos-de-prova foram fixados com cola epóxi a um substrato de argamassa $\operatorname{armada}^{4.8}$. Cada corpo-de-prova tinha $60 \%$ de interface argamassa nova/juçara e $40 \%$ argamassa nova/argamassa original. Foram realizadas seis determinações, utilizando um dinamômetro, conforme especificado na NBR 13528 (ABNT, 1995), e seguindo o procedimento de ensaio dessa norma.

Após o décimo ciclo térmico foram cortadas, com disco de corte, faixas no sentido longitudinal às ripas de juçara, com largura aproximada de $70 \mathrm{~mm}$, seguindo o procedimento descrito anteriormente e sendo mantido uma parte do corpo-de-prova como testemunho da avaliação. O ensaio após o décimo ciclo permitiu avaliar as seguintes condições:

a) aderência do sistema de restauro aos materiais originais, considerando $50 \%$ de interface argamassa nova/juçara e $50 \%$ argamassa nova/argamassa original e;

4.8 Substrato-padrão especificado pela NBR 14.082 (ABNT, 1998) para ensaios de resistência de aderência e tempo em aberto de argamassa colante. 
b) aderência do sistema de restauro à argamassa original, ou seja, $100 \%$ de interface argamassa nova/argamassa original.

De modo a obter um parâmetro para a avaliação do desempenho, determinou-se a resistência de aderência argamassa nova/argamassa original em um testemunho não submetido ao ciclo térmico e à resistência à tração direta da argamassa original, esta última considerada como a resistência de aderência potencial (máxima).

As Figuras 4.12 e 4.13 ilustram os corpos-de-prova submetidos a esses ensaios.

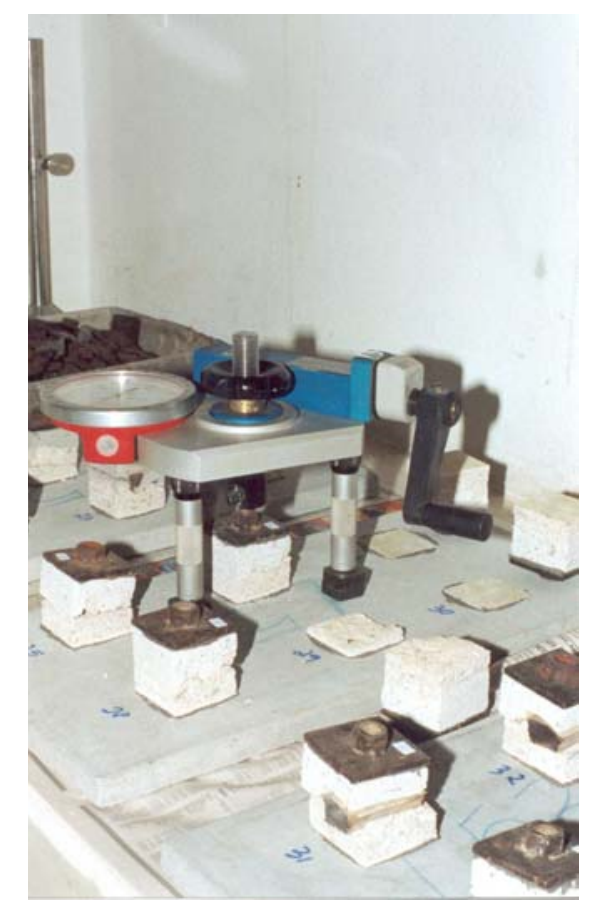

Figura 4.12 - à esquerda: corpos-de-prova para a determinação da aderência do sistema de restauro à argamassa original; à direita: corpos-deprova para a determinação da aderência do sistema de restauro aos materiais originais considerando $50 \%$ de interface argamassa nova/juçara e $50 \%$ argamassa nova/argamassa original. 


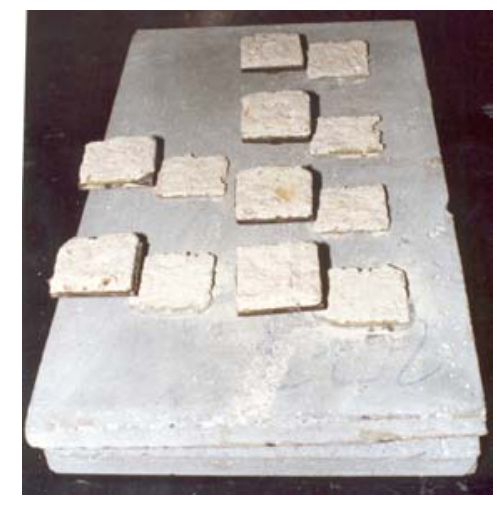

Figura 4.13 - Corpos-de-prova ensaiados para a determinação da resistência à tração direta da argamassa original. 


\section{LEVANTAMENTO CADASTRAL DO FORRO EM ESTUQUE DA EDIFICAÇÃO VILA PENTEADO}

Este Capítulo foi organizado de modo a reunir todas as informações relevantes para o entendimento do sistema de forro e de seu mecanismo de deterioração, partindo do levantamento bibliográfico da técnica construtiva de forro em estuque, seguido da descrição do sistema construído na edificação Vila Penteado. Na seqüência, é apresentada uma avaliação do estado do forro avaliado na fase preliminar desta pesquisa, numa inspeção visual em 1997.

A principal contribuição do resgate da história da edificação (Anexo $A$ ) foi a identificação das duas fases de abandono pelas quais passou. A primeira durante a década de quarenta após o falecimento da Condessa Ana Álvares Penteado, em 1938. Esta fase teve duração de quase dez anos. A segunda em meados da década de 60, quando o curso de graduação da Faculdade de Arquitetura e Urbanismo da USP foi transferido para a Cidade Universitária. Esta fase teve duração de aproximadamente sete anos. A falta de cuidados inerentes ao abandono e a dificuldade de manutenção da edificação propiciaram o avanço da deterioração em diversas partes do forro em estuque.

\subsection{Técnica construtiva de forro em estuque - levantamento bibliográfico}

Considerado uma arte durante a antigüidade, forros em estuque eram feitos por artesãos que dominavam os seus materiais e as técnicas de modelagem. Ao remontar a sua 
história, identificam-se períodos de esquecimento e de renascimento desta técnica construtiva.

\subsubsection{Histórico da técnica de estuque}

Conforme SEGURADO (1936), existem registros da utilização do estuque como revestimento desde a civilização egípcia. Ferramentas utilizadas pelos estucadores desta época foram reproduzidas nas pinturas dos túmulos faraônicos. As civilizações gregas e romanas também empregaram esta técnica em suas construções, decorada com as pinturas afresco. ${ }^{5.1}$ As invasões árabes trouxeram uma nova fase de difusão desta técnica durante a permanência de seu povo na Europa Ocidental, após ter caído em desuso com o início do cristianismo. A Renascença italiana a fez reviver como arte, com a descoberta das ruínas romanas, tendo pintores e escultores renomados como artesãos: Michelangelo, Primaticcio, Vasari, Bramante, Rafael, e outros. Estes mestres deixaram suas oficinas e passaram a trabalhar diretamente nas edificações, inscrevendo suas obras em forros, frontões, arcos, escadas, paredes, etc.

A bibliografia pesquisada que data do final do século XIX não abrange a técnica de aplicação do estuque, mas a execução de sua argamassa. As definições apresentadas por RAINVILLE (1880) e RAMÉE (1875) sintetizam como estuque: reboco conhecido desde os antigos romanos, imitando o mármore, o qual pode ser polido, colorido, decorado com afrescos e, em alguns casos, com decorações em relevo.

\footnotetext{
${ }^{5.1}$ Entende-se por pinturas afresco aquelas realizadas com o estuque ainda fresco, nas quais as tintas são diluídas em água potável, incorporando-se ao estuque devido à propriedade absorvente da cal (AURÉLIO, 1988).
} 


\subsubsection{Descrição da técnica de estuque}

As informações sobre a técnica construtiva do forro em estuque foram agrupadas nas etapas: preparação da argamassa, preparação do suporte e técnica de aplicação.

a) Preparação da argamassa

Geralmente o estuque era constituído de duas ou três camadas de argamassa. Nos casos em que duas camadas eram empregadas, a primeira era constituída de uma argamassa de cal e a segunda de uma fina camada de argamassa de gesso. A argamassa de cal, apesar de apresentar melhor desempenho, era considerada esteticamente desagradável, devido à sua cor, por isso esta camada raramente era deixada aparente.

Existem divergências quanto ao proporcionamento das argamassas nas referências pesquisadas, embora todas afirmem que esta dosagem é baseada no estuque italiano. Para LEITÃO (1896), o estuque italiano não utilizava gesso, sendo aplicado em três camadas de argamassa: a primeira de cal e areia branca grossa, na proporção $1: 2^{5.2} \mathrm{em}$ volume, a segunda de cal e areia branca fina, de mesma proporção e, a terceira, com os mesmos materiais da camada anterior alterando a proporção para $1: 1$. O acabamento era realizado com pasta de cal. LEITÃO (1896) refere-se também ao estuque escaiola, no qual a argamassa era constituída de areia fina, cal em pasta e pó de mármore em

\footnotetext{
5.2 Para BOCCHINO, F. (1990), a primeira camada de argamassa do estuque utilizava proporção $1: 1,5$ proporção cal : areia e para a execução de cornijas e outros elementos maciços a proporção argamassa : pó de mármore era $2: 1$.
} 
partes iguais. O estuque era geralmente destinado a paredes rebocadas e secas, sendo a argamassa aplicada utilizando uma talocha ${ }^{5.3}$.

De acordo com RAMÉE (1875), o estuque era constituído de três camadas. A primeira camada era de argamassa de cal e areia fina, podendo-se acrescentar gesso de construção na proporção 2 : 1 (gesso de construção: argamassa). Nas segunda e terceira camadas, a proporção entre gesso de construção e argamassa deveria ser mantida em $1: 3$. Para a aplicação da terceira camada, recomendava-se que as anteriores estivessem completamente secas; podendo ser acrescido na argamassa desta camada, esporadicamente, pó de mármore na proporção $1: 1$.

Embora o estuque italiano fosse aplicado em três camadas, as bibliografias francesa e portuguesa mencionam apenas duas. A primeira, cuja aplicação denominava-se esboçar e a segunda dobrar ou de estender, ambas com a utilização de talocha. A pasta de estender era constituída de partes iguais de cal em pasta e gesso em pó.

Diversos autores [RAINVILLE (1880), REYNAUD (1867), PRUD'HOMME (1895) e LEITÃO (1896)] mencionam a utilização da cola de Flandre ${ }^{5.4}$ ou outros materiais gelatinosos também denominados de cola, na argamassa de estuque de gesso para retardar a pega e aumentar a dureza, tornando o revestimento apto a receber polimento. LEITÃO (1896) sugeriu a proporção de $25 \mathrm{~kg}$ de gesso para 18 litros de água com cola forte ou gelatina de peixe dissolvida.

A coloração dos estuques era obtida com a adição de pigmentos na argamassa. Para tons amarelo e verde adicionava-se peróxido de ferro hidratado ou óxido de cromo,

\footnotetext{
${ }^{5.3}$ Segundo SEGURADO (1936), a talocha é ferramenta principal do estucador. É uma tábua retangular de $300 \times 200 \mathrm{~mm}^{2}$ com uma de suas faces levemente curva e a outra com uma alça (semelhante a uma desempenadeira).
} 
respectivamente. Os óxidos de magnésio, de cobre e bicarbonatos de cobre também eram empregados como corantes.

A mistura da argamassa era mecanizada ou manual. Esta última, denominada na época de "preparação a braço", caracterizava-se por ser feita sobre estrados de madeira denominados pela bibliografia portuguesa de "amassadoiros", utilizando um pilão de ferro pesando aproximadamente $4 \mathrm{~kg}$. $\mathrm{O}$ processo mecanizado era empregado em obras mais importantes, utilizando um misturador. Algumas ferramentas e o equipamento utilizado na mistura e aplicação da argamassa de estuque são ilustrados na Figura 5.1.
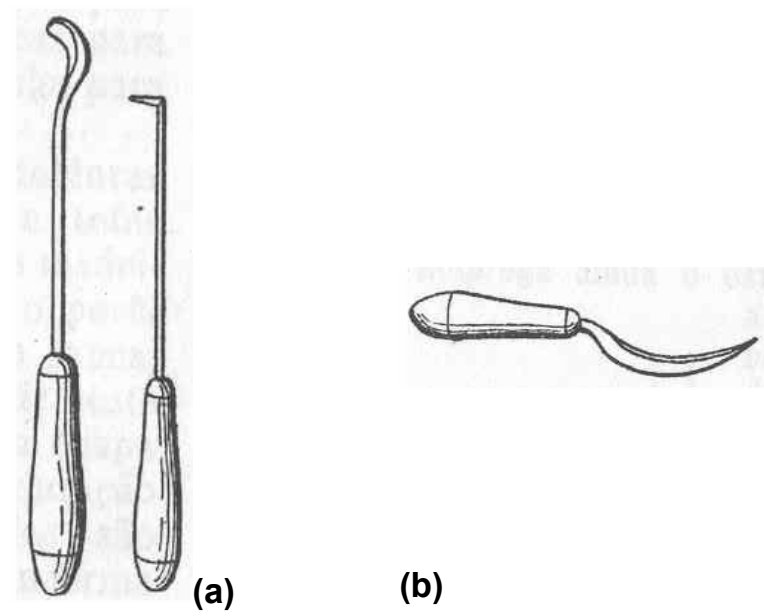

(b)

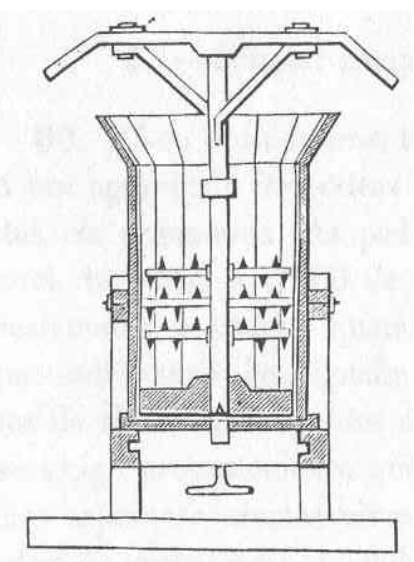

(c)

Figura 5. 1 - Ferramentas (SEGURADO, 1936) e equipamento (LEITÃO, 1896) utilizados para a preparação da argamassa: (a) ganchetas; (b) ferro de corte; (c) "amassador mecânico de Roger".

b) Preparação do suporte

Não se encontraram registros na bibliografia do século XIX sobre os tipos de suporte de estuque utilizados. Segundo SEGURADO (1936), os egípcios costumavam assentar o estuque sobre canas entrelaçadas com cordas, que posteriormente foram substituídas por tramas de madeira. De acordo com LONDON (1992) foi somente a partir de 1920, que passaram a ser utilizadas telas metálicas, procedimento comum até os dias de hoje.

\footnotetext{
${ }^{5.4}$ Não foi encontrado o significado de Flandre.
} 
Estas telas podem ser fixadas em barrotes distribuídos de forma quadricular, com espaçamentos entre 30 e $50 \mathrm{~cm}$, quando o estuque for utilizado como revestimentos de tetos, ou ainda, em divisórias de madeira ou gesso quando em paredes.

O madeiramento do suporte da tela deve ser independente do telhado, evitando a influência de movimentação higrotérmica, que gera fissuração no estuque. Apesar de não oferecer risco à segurança do usuário, o aparecimento dessas fissuras causa-lhe insegurança.

BORGES (1972) sugeriu que as dimensões dos barrotes fossem definidas em função do tamanho do cômodo e do vão, conforme apresentado Tabela 5.1 e distribuídos como mostra a Figura 5.2.

Tabela 5- 1 Dimensões dos sarrafos sugeridas por BORGES (1972).

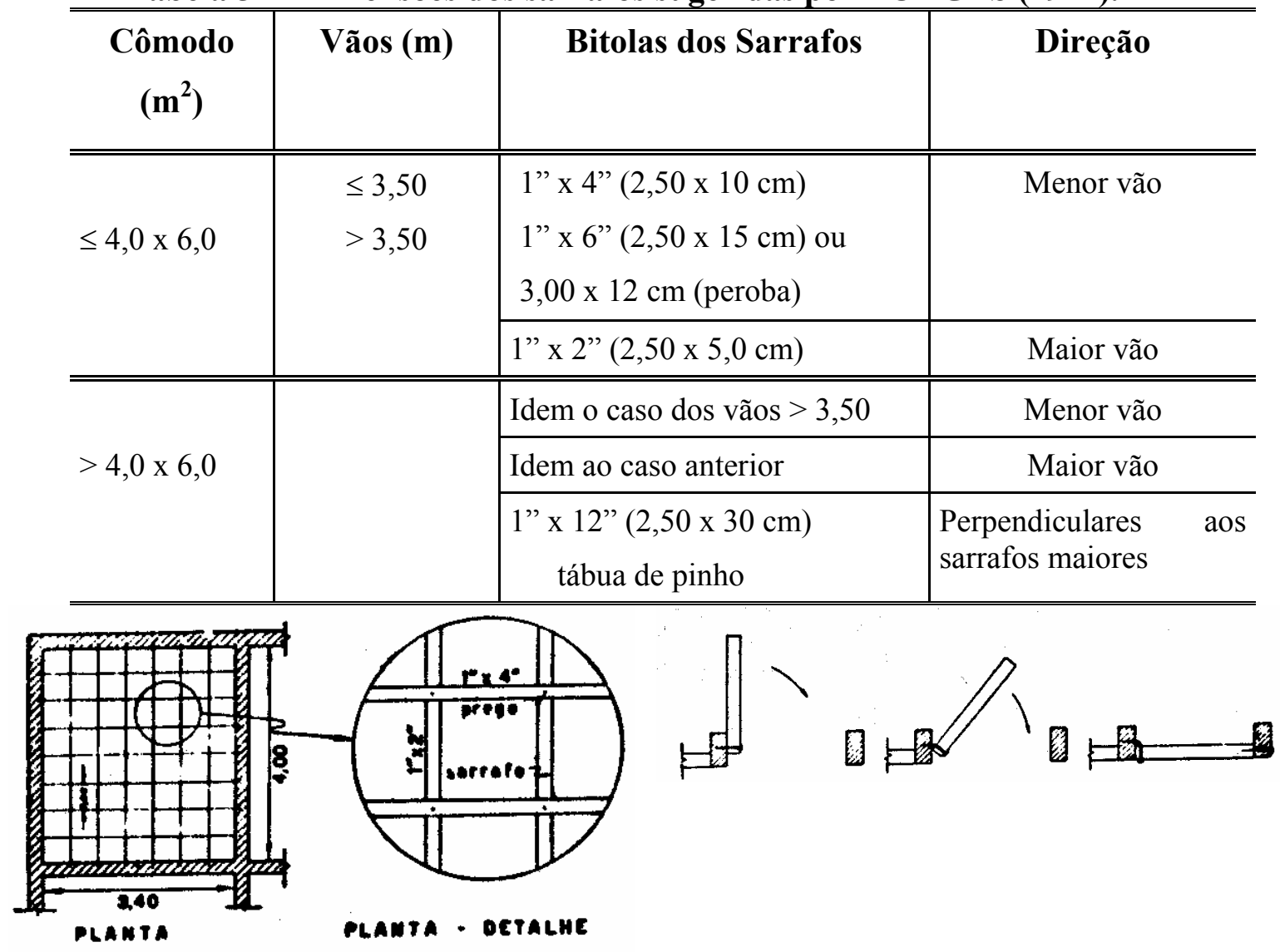

Figura 5. 2 - Croqui visto em planta e em corte do madeiramento de suporte da tela sugerido por BORGES (1972). 
Alternativamente, AZEREDO (1988) propôs que fossem colocadas vigas de madeira espaçadas de 2 a 3 metros, apoiadas nas paredes, na direção do menor vão. Na altura dessas vigas deveriam ser fixados barrotes de peroba, com seção transversal 1" x 6" $\left(2,5 \times 15,0 \mathrm{~cm}^{2}\right)$, contraventados com tarugos de pinho, de 1 " $\mathrm{x} 4$ " $\left(2,5 \times 10,0 \mathrm{~cm}^{2}\right)$.

Tanto na proposta de BORGES (1972) como na de AZEREDO (1988), os espaçamentos dos barrotes devem permitir que a emenda da tela seja realizada sobre a madeira e a tela deve ser fixada em todos os lados dos quadrados.

De acordo com MERRITT; RICKETTS (1994), a tela metálica deve ser preferencialmente galvanizada, favorecendo sua durabilidade. No Brasil a tela mais empregada é a tela deploié.

c) Técnica de aplicação

Segundo BORGES (1972), a aplicação da argamassa é geralmente realizada em duas camadas. A primeira deve ser pela parte superior da tela, necessitando de dois funcionários, o pedreiro e um servente. Enquanto o servente segura o suporte, denominado por SEGURADO (1936) de esparável (Figura 5.3) que servirá de base de um painel, o pedreiro preenche-o de forma que toda a tela fique recoberta, compactando a argamassa. A camada de acabamento, sob a tela, deverá ser aplicada como um emboço após a primeira adquirir resistência inicial. 


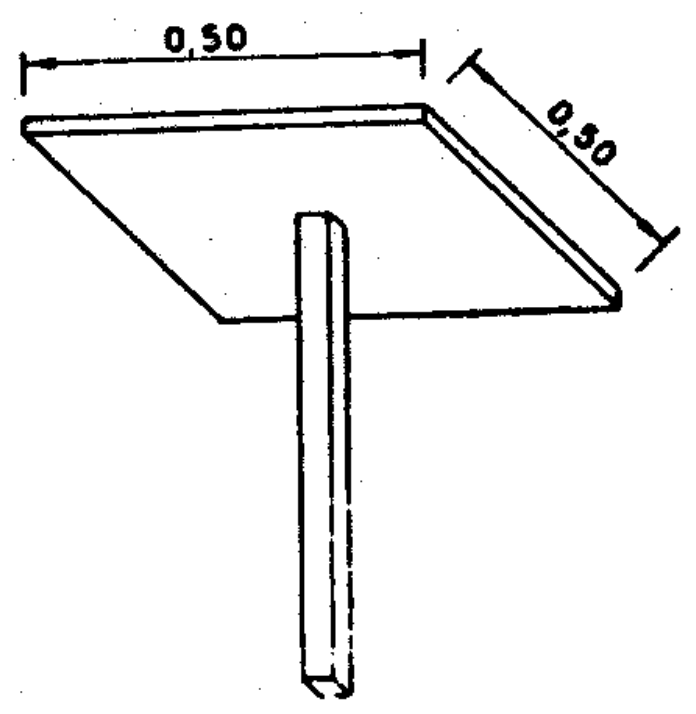

Figura 5. 3 - Artefato para aplicação da argamassa no forro em estuque (BORGES, 1972). Este artefato é denominado por SEGURADO (1936) de esparável.

Quando não for possível seguir este procedimento, a aplicação pode ser feita pela parte inferior, utilizando uma estopa, com a qual o pedreiro esfrega a argamassa contra a tela. Por sua vez, a aplicação desta maneira é menos econômica e apresenta falhas mais freqüentemente.

Segundo SEGURADO (1936) o acabamento era dado com a colher de estucador, cujas dimensões são maiores que a de pedreiro. O acabamento polido era feito na argamassa endurecida. Para tanto, a superfície do estuque era umedecida com uma esponja, o polimento era dado com pedra pomes ou grés muito fino e para finalizar, esfregava-se um feltro embebido em água e sabão.

Outros acabamentos decorativos são as molduras e ornamentos pintados ou em relevo. Para auxiliar a pintura utilizava-se a estampilha, que é um molde vazado ou em papel ou em chapas de zinco. As molduras e ornamentos em relevo eram feitos empregando moldes de madeira, podendo estes ser revestidos por uma chapa de zinco, para aumentar 
a sua durabilidade. Alguns moldes de molduras e de estampilha são apresentados na Figura 5.4.

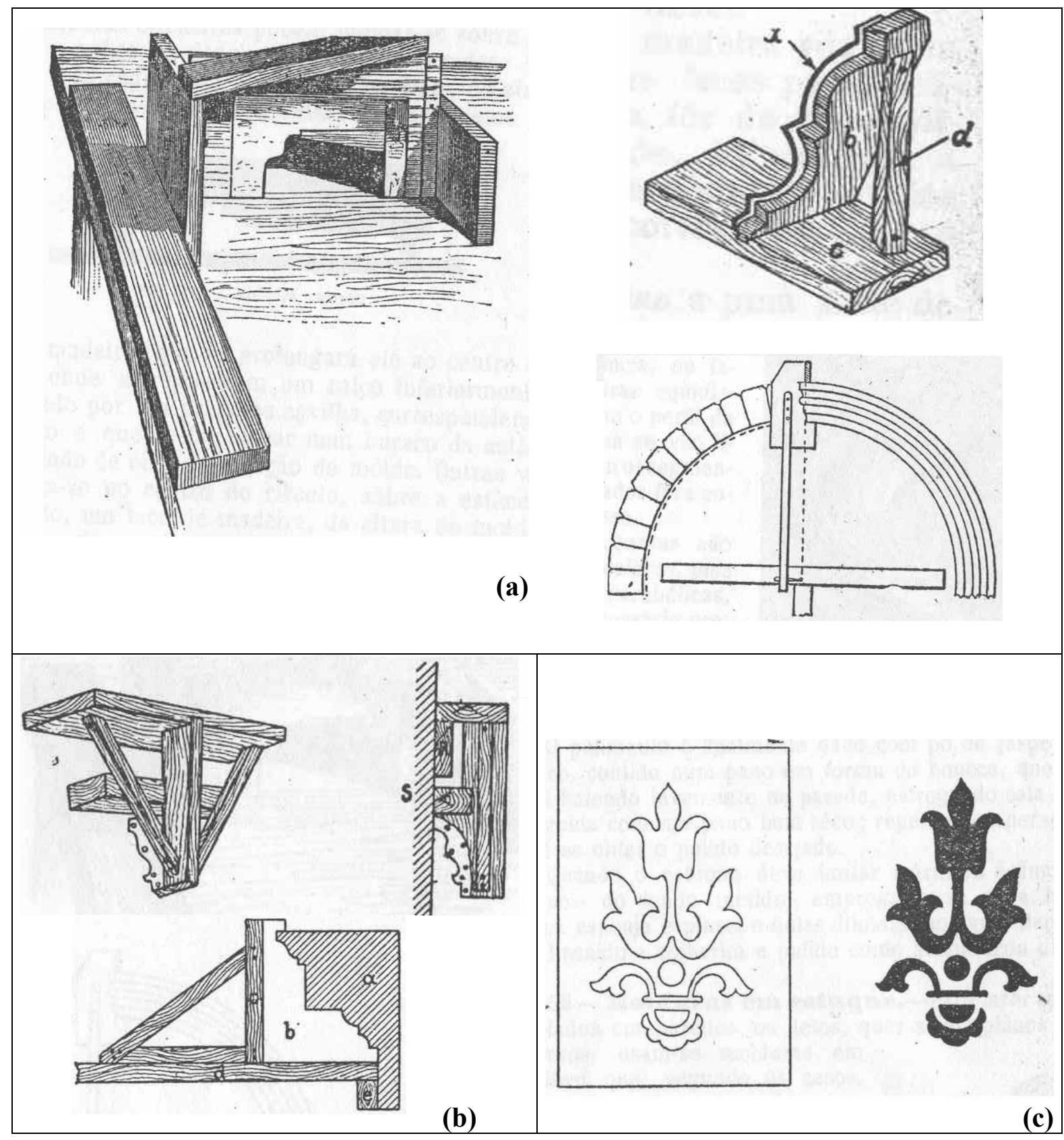

Figura 5. 4 - Moldes utilizados para execução de: (a) molduras; (b) cimalhas; (c) pinturas (SEGURADO, 1936).

\subsection{Descrição do sistema de forro em estuque da edificação Vila Penteado}

Atualmente, grande parte dos forros em estuque da edificação Vila Penteado apresenta pintura lisa. Originalmente possuíam pinturas murais de grande valor artístico e em 
alguns cômodos, bordas em relevo e arestas arredondadas, características estas de projetos requintados do início do século. Segundo o Relatório da arquiteta Regina Tirello, realizado após a fase de prospecção cromática, no início da década de noventa, todos os forros em estuque da antiga residência são decorados com pintura mural. Nas salas correspondentes aos cômodos íntimos, a decoração limita-se às faixas de 40 a $70 \mathrm{~cm}$ no contorno dos ambientes, enquanto nos ambientes sociais as pinturas estendem-se por toda a superfície.

$\mathrm{Na}$ inspeção visual da edificação em 1997, constatou-se que as salas do pavimento térreo com forro em estuque sem adornos em relevo estavam localizadas nos fundos da edificação, considerando o projeto original, isto é quando a edificação tinha como fachada principal aquela voltada para a Av. Higienópolis. Acredita-se, portanto, que a inexistência de adornos deve-se ao fato desses cômodos terem sido destinados aos serviçais ou às suas áreas de atuação.

Como pôde-se observar, a partir da avaliação visual realizada nas regiões de colapso do forro, a argamassa do estuque foi aplicada sobre ripas de juçara (Euterpe eudulis), palmeira abundante na Mata Atlântica no período da construção. As ripas possuem aproximadamente $50 \mathrm{~cm}$ de comprimento e seção circular ${ }^{5.5} \mathrm{com}$ 1,5 cm de diâmetro. No pavimento térreo as ripas de juçara estão pregadas em esperas de madeira e estas aos caibros com seção de aproximadamente $5 \times 10 \mathrm{~cm}^{2}$. No pavimento superior as ripas estão pregadas diretamente nos caibros fixados ao madeiramento do telhado. Em ambos os casos, as ripas de juçara estão envolvidas em argamassa, aparentando um "sanduíche", como mostra a Figura 5.5.

\footnotetext{
${ }^{5.5}$ As ripas de juçara não possuem seção completamente uniforme, possivelmente devido à dificuldade de beneficiamento existente na época.
} 


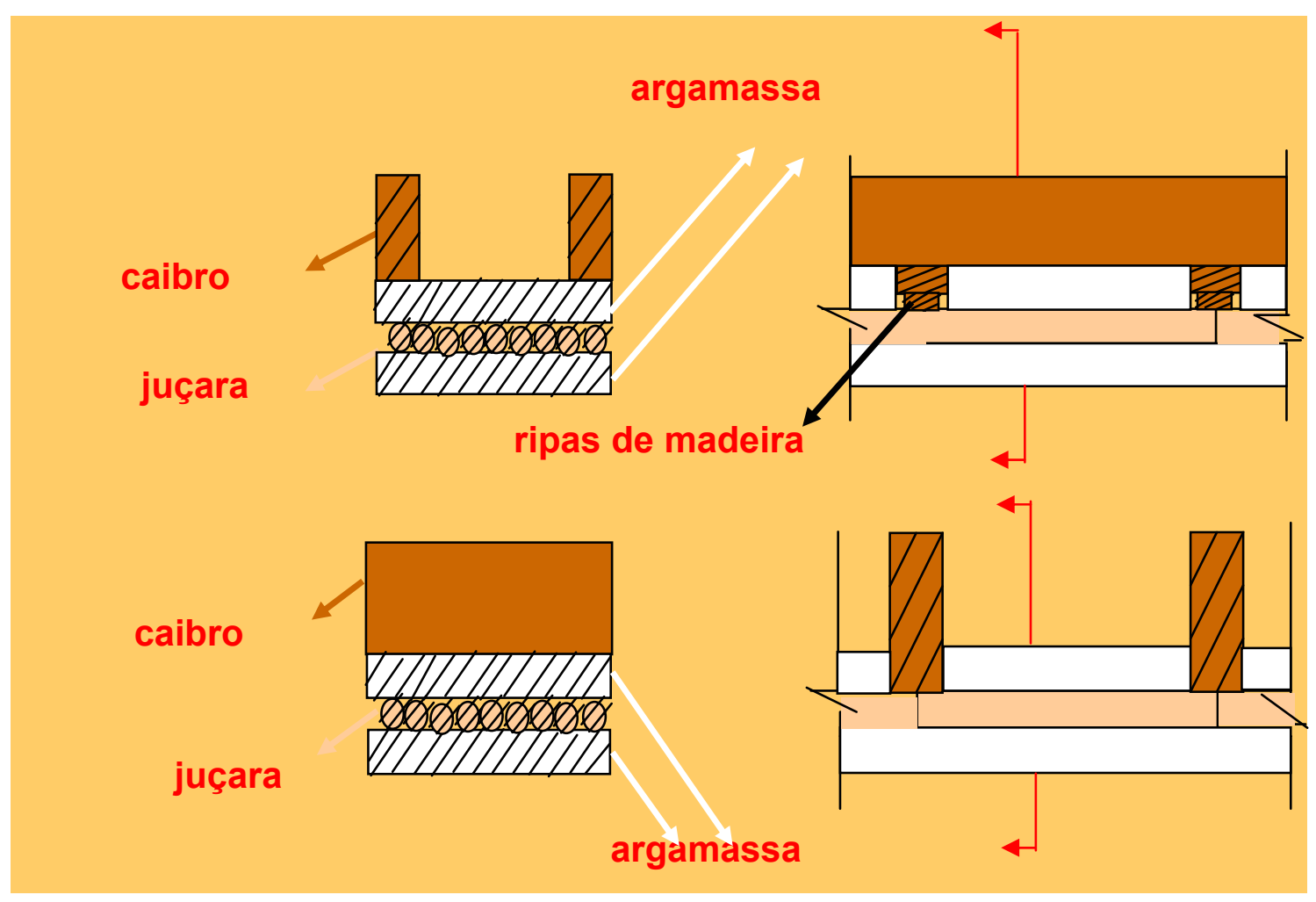

Figura 5. 5 - Representação esquemática do sistema de forro em estuque:

(a) pavimento térreo; (b) pavimento superior.

Comparando a descrição da técnica empregada na edificação Vila Penteado com a técnica de estuque descrita na literatura, pode-se inferir que é semelhante à descrita por SEGURADO (1936) no que se refere ao suporte. Quanto à aplicação da argamassa, como as ripas de juçara formam um substrato, qualquer uma das camadas de argamassa pode ter sido aplicada primeiro, não sendo necessário iniciar pela camada superior com a utilização do esparável (Figura 5.3). 


\subsection{Registro cronológico de vistorias, recomendações de recuperação e intervenções no forro}

As informações referentes aos serviços de manutenção e conservação do forro da edificação foram organizadas em ordem cronológica, principalmente no que tange ao ocorrido após o segundo desabamento parcial do forro em estuque, em 1994.

Dezembro de 1989 - a empresa TECNOMAD Consultoria e Serviço S/C Ltda. foi contratada para fazer uma vistoria do estado de conservação das estruturas e componentes de madeira da edificação. A referida empresa apresentou como produto do serviço contratado o Relatório Técnico 161/89. Este Relatório documentou a presença generalizada de cupins subterrâneos no pavimento térreo, no porão e na área externa da edificação. Estes cupins foram identificados como Coptotermes havilandii (IsopteraRhinotermitidae). Foi também constatada, a ocorrência de ataque de cupins de madeira seca no sistema de cobertura e forros, principalmente nos elementos em Pinho de Riga. Neste caso não foram encontrados insetos vivos. Os resíduos fecais encontrados indicaram o ataque de cupins da família Kalotermiditae (provavelmente da espécie Heterotermes brevis). Alguns trechos do forro já apresentavam indícios de apodrecimento devido à presença de umidade. Os cômodos S05 (77), S07 (78) e S08 $(76)^{5.6}$ foram citados por apresentarem infiltrações. Nessa ocasião, foi identificado o severo apodrecimento do forro em estuque do cômodo S19 (região abaixo da viga metálica existente, onde foi coletada a amostra S19A). Como tratamento foi recomendado:

\footnotetext{
${ }^{5.6}$ A numeração entre parênteses, mencionada no Relatório Técnico 161/89, refere-se à identificação dos cômodos pela FAU.
} 
a) tratamento químico do solo para os cupins subterrâneo: técnica de barreira química junto aos baldrames do porão, no seu interior e na região periférica da edificação, devendo contemplar também os pontos isolados onde ocorreram manifestações de cupins em elementos sem contato com o solo;

b) tratamento químico da madeira para os cupins de madeira seca e para as brocas de madeira encontradas no mobiliário - especificação de produtos como: pentox super ${ }^{\circledR}$, penetrol ${ }^{\circledR}$, xilotox ${ }^{\circledR}$, jimo cupim ${ }^{\circledR}$ incolor ou similares e;

c) eliminação das fontes de vazamento de água existentes. Ressaltou-se a existência de inclinação inadequada do telhado dos dois anexos que foram adicionados ao prédio original, tendo sido relacionado a esta deficiência o refluxo de águas de chuva.

1992 - a deterioração do forro resultou no desabamento de parte do mesmo, em uma das varandas externas, junto à mapoteca, cômodo T10;

04 de julho de 1994 - desabamento parcial do forro nas dependências da mapoteca (ADM 18294/FAU/050794). Esta ocorrência foi comunicada à Prefeitura da Universidade de São Paulo e, a partir de então, foram realizados inúmeros serviços emergenciais.

Julho de 1994 - A Diretoria e a Congregação da FAUUSP interditaram a edificação até a conclusão do Parecer Técnico solicitado à comissão formada pelos seguintes profissionais: Prof. Dr. Antônio Luiz Dias de Andrade (FAU), Art ${ }^{\mathrm{a}}$. Regina Tirello, (CPC - Comissão do Patrimônio Cultural da USP), Arqt ${ }^{\mathrm{a}}$. Neide Angela Joppert Cabral (Prefeitura da Universidade) e o Eng $^{\circ}$ Fausto Tarran (FUNDUSP). Acompanharam esta comissão os Profs. Drs. Nestor Goulart Reis Filho, Gustavo Neves da Rocha Filho e 
Murillo Marx. Nesta época foi realizado um registro fotográfico da área sinistrada, apresentado no Anexo $\boldsymbol{E}$.

A Comissão de avaliação do forro expressou-se em carta redigida por seu coordenador, Prof. Dr. Antonio Luiz Dias de Andrade. Após uma vistoria preliminar foram apontadas como causas do desabamento:

- o ataque de térmitas, danificando a trama de juçara responsável pelo suporte do estuque e;

- a presença de umidade, proveniente de infiltração pluvial, levando ao desabamento do forro.

No mesmo documento foram propostas:

- a interdição do prédio até que todos os cômodos fossem minuciosamente vistoriados, identificando e reforçando aqueles que apresentassem risco eminente de desabamento e;

- a elaboração de um projeto de consolidação do forro, no qual fosse substituído o sistema de suporte do estuque, devido ao desconhecimento do estado de deterioração das ripas de juçara, uma vez que estas são recobertas por "argamassa de gesso” em ambos os lados.

Sugeriu-se fixar o estuque a uma tela metálica presa à estrutura da cobertura, utilizando pinos de latão, conforme a ilustração apresentada no Anexo F. Propôs-se também a utilização de resina para garantir a consolidação da argamassa. $O$ coordenador da comissão mencionou também o caso de descolamento da argamassa das ripas de juçara, ocorrido em 1992, ressaltando que neste caso houve o ataque de térmitas.

Agosto de 1994 - uma vez finalizada a vistoria definitiva do forro pela referida Comissão, foram propostos: 
- o escoramento imediato do forro dos cômodos T18 (04), T12 (20), T03 (29), T04 (33), T06 (37), T09 (42), S22 (09), S20 (12), S19 (18), S12B (19), S12 (20), S17 (22), S11 (24), S07 (36) e S10 (39) ${ }^{5.7}$, devido ao avançado grau de deterioração e;

- a substituição do sistema de calhas referente à cobertura do patamar da escada externa de acesso às dependências, uma vez que este encontrava-se condenado.

A equipe ratificou a importância da elaboração de um projeto de consolidação, visto que a proposta de escoramento era uma medida emergencial para liberação da edificação. O mapeamento das manifestações patológicas pertence ao arquivo da FAUUSP.

Paralelamente à vistoria, o mapeamento das áreas com pinturas murais foi realizado pela equipe do CPC. As informações fornecidas por este mapeamento foram apresentadas na descrição do forro e as plantas ilustrativas pertencem ao arquivo da FAUUSP.

Março de 1995 - foi realizada uma reunião com professores e funcionários da EPUSP e da FAUUSP, visando a elaboração de um Relatório Técnico sobre os danos, com propostas de recuperação do forro, para intervenção posterior. Contudo não se localizou nenhum documento referente à concretização desta Proposta.

Julho de 1995 - foi encaminhado à coordenadora da CPC um memorial de indicações técnicas para a execução dos serviços de manutenção dos forros de madeira, elaborado pela Arqt ${ }^{\mathrm{a}}$ Regina Tirello. A principal causa relacionada aos danos foi a umidade proveniente de vazamento no telhado. Propôs-se a substituição da madeira deteriorada

\footnotetext{
${ }^{5.7}$ A numeração entre parênteses mencionada no Relatório de atividades refere-se a mesma empregada pela FAU e equipe do CPC no projeto de restauração pictórica.
} 
por tábuas de mesma dimensão, em cedrinho ou ipê, após solucionado o vazamento. A pintura desses componentes deveria ser baseada na estratigrafia cromática que permitiu constatar que o forro de madeira era pintado com tinta a óleo cor creme-amarelada (monocromática).

Setembro de 1995 - objetivando a consolidação da argamassa do forro em estuque foram realizados ensaios com resinas à base de silicone da Rhodia. O trabalho foi realizado no Laboratório da Divisão de Silicones desta empresa e foi acompanhado pela Arqt ${ }^{\mathrm{a}}$ Regina Tirello, que apresentou os resultados num Relatório entregue em março de 1996 para a Diretoria da FAU.

Este Relatório foi dividido em duas etapas:

- A primeira consistiu na apresentação das propostas de vários técnicos que vistoriaram o forro da edificação Vila Penteado. Dentre as propostas mencionadas, ressalta-se aquela elaborada pelos técnicos da Divisão de Madeira, do IPT $^{5.8}$ e pelo Prof. Dr. Fusco da EPUSP. A primeira proposta sugeriu a realização do levantamento do tipo de ocupação, das posições dos vigamentos, das dimensões e espécies de madeira, da avaliação do peso do forro, das formas de fixação das ripas de juçara ao vigamento, da análise estrutural do conjunto em função das cargas previstas e do estado de sanidade do vigamento. A segunda proposta sugeriu a utilização de polipropileno injetado. Conforme consta na documentação, esta proposta não foi avaliada devido à falta de especificação quanto à viscosidade do material e ao procedimento de aplicação;

${ }^{5.8}$ A proposta elaborada pelo IPT não foi aprovada pela FAU. 
- A segunda etapa consistiu na apresentação dos resultados da avaliação dos produtos RHODIASTIC 567® e do RHODORSIL CONSOLIDANT®.

O RHODIASTIC 567® é um selante de juntas de dilatação à base de silicone disponível no mercado, até então não empregado em restauração. Este produto foi considerado adequado quanto à capacidade de consolidação. Entretanto, sua utilização neste caso não foi considerada conveniente, uma vez que não apresentou viscosidade adequada à aplicação, mesmo quando diluído, além de aumentar consideravelmente o peso próprio do forro.

O RHODORSIL CONSOLIDANT® é um produto destinado à consolidação de materiais minerais porosos, constituído de silicatos de etila associados com catalisadores neutros e resinas metílicas. Os resultados não foram conclusivos, pois a quantidade disponível para ensaio era pequena. Na ocasião, o produto não se encontrava disponível no mercado nacional. Entretanto, foi observado o aumento da coesão da argamassa após a utilização desse produto.

Ainda nesta etapa informou-se que a RHODIA comercializava no mercado europeu, na ocasião, o produto $\mathrm{RHOCAGIL} \AA$. Trata-se de uma resina de poliuretano, que se torna uma espuma sólida impermeável e de baixo peso específico ao polimeralizar-se. Esse produto se apresentou adequado quando empregado em restauro de monumentos naquele continente. Este produto não foi avaliado por não ser disponível no Brasil.

Janeiro de 1996 - a Comissão de Pós-Graduação da FAU aceitou a modificação do sistema de suporte do forro pelo sistema proposto pelo Prof. Dr. Antonio Luiz de Andrade. O novo sistema consistia em substituir os pontaletes existentes por tirantes presos na estrutura da cobertura. 
Primeiro trimestre de 2000 - realizou-se a tentativa de fixação com parafusos proposta em 1994 e detalhada em 1999 (Anexo F) em alguns cômodos da edificação. A fixação não teve o resultado esperado e ruiu parte do forro que se encontrava bastante comprometida, região da coleta da amostra S19A.

\subsection{Estado de conservação do forro em estuque}

As informações que constam neste item são fruto da inspeção visual realizada em 1997 no início deste estudo. As fissuras e as demais anomalias encontradas foram registradas em fotografias.

\subsubsection{Avaliação quanto ao estado de fissuração}

A tipologia das fissuras observadas no forro em estuque da maioria dos cômodos é característica de estuques. Estas fissuras devem-se, muito provavelmente a movimentação higrotérmica e aos diferentes coeficientes de dilatação dos materiais empregados (madeira, argamassa, eletrodutos). Nestes casos as fissuras não correspondem ao risco eminente de desmoronamento e qualquer tipo de colmatação rígida será ineficaz, pois as fissuras tenderão a reincidir. Este tipo de fissura é classificada no meio técnico como fissura viva.

O forro em estuque do segundo pavimento apresentou-se mais fissurado, provavelmente por estar submetido a condições de exposição mais severas.

Ressalta-se que no forro do cômodo S10 foram encontradas fissuras de grande abertura acompanhadas de deformações do forro bastante acentuadas. Comparando a distribuição atual com a indicada nas plantas do projeto original verificou-se a remoção de uma parede, o que provavelmente ocasionou o aparecimento dessas fissuras.

Nas áreas onde a restauração pictórica foi finalizada recentemente, a identificação de fissuras não foi possível. 


\subsubsection{Avaliação quanto à presença de umidade}

Foi constatado que poucas regiões apresentavam problemas de infiltração. Puderam-se constatar mancha de umidade e problemas de vazamento, provavelmente ocasionados por infiltrações pluviais, no cômodo S11.

\subsubsection{Avaliação quanto aos indícios de biodeterioração}

A presença de inúmeras folhas de compensado usadas como escoramentos, cobrindo grande parte do forro em estuque, diminuiu a possibilidade de inferir sobre uma possível biodeterioração somente por inspeção visual. A exemplo disto, no cômodo S11, onde foram constatados problemas de infiltração e o apodrecimento do escoramento, observou-se após a remoção parcial da folha de compensado que o forro apresentava-se aparentemente em bom estado. A biodeterioração dessa região só ficou explícita durante a coleta de amostras da argamassa realizada pelo sótão, quando foi possível constatar o avançado grau de deterioração das ripas de juçara. 


\section{RESULTADOS E DISCUSSÕES}

\subsection{Anomalias observadas durante a amostragem}

As anomalias observadas durante a inspeção visual realizada em 1997 foram apresentadas no item 5.4. No entanto durante a coleta de amostras novos aspectos foram observados, alguns deles associadas com características evidenciadas pelas análises de laboratório e, por isso apresentadas a seguir.

\subsubsection{Pavimento térreo}

A Figura 6.1 mostra a região onde ocorreu o desabamento do forro em 1994, no cômodo T10, mapoteca. Com a observação detalhada desta região verificou-se a presença de indícios de biodeterioração generalizada, abrangendo as ripas de juçara e os elementos em madeira (Figura 6.2).

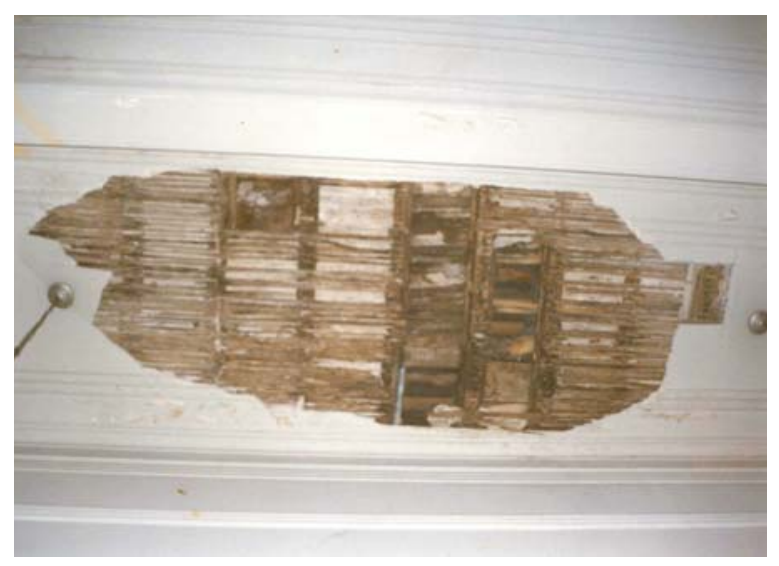

Figura 6. 1 - Vista geral da região do forro (aproximadamente $2 \mathrm{~m}^{2}$ ) que desabou do cômodo T10 (mapoteca). 
A Figura 6.2 a mostra a presença de micélio e de frutificações de fungos no madeiramento, enquanto a Figura 6.2 b mostra ripas de juçara completamente danificadas, tendo sido identificada a formação de galerias, o que pode indicar a ação de cupins.
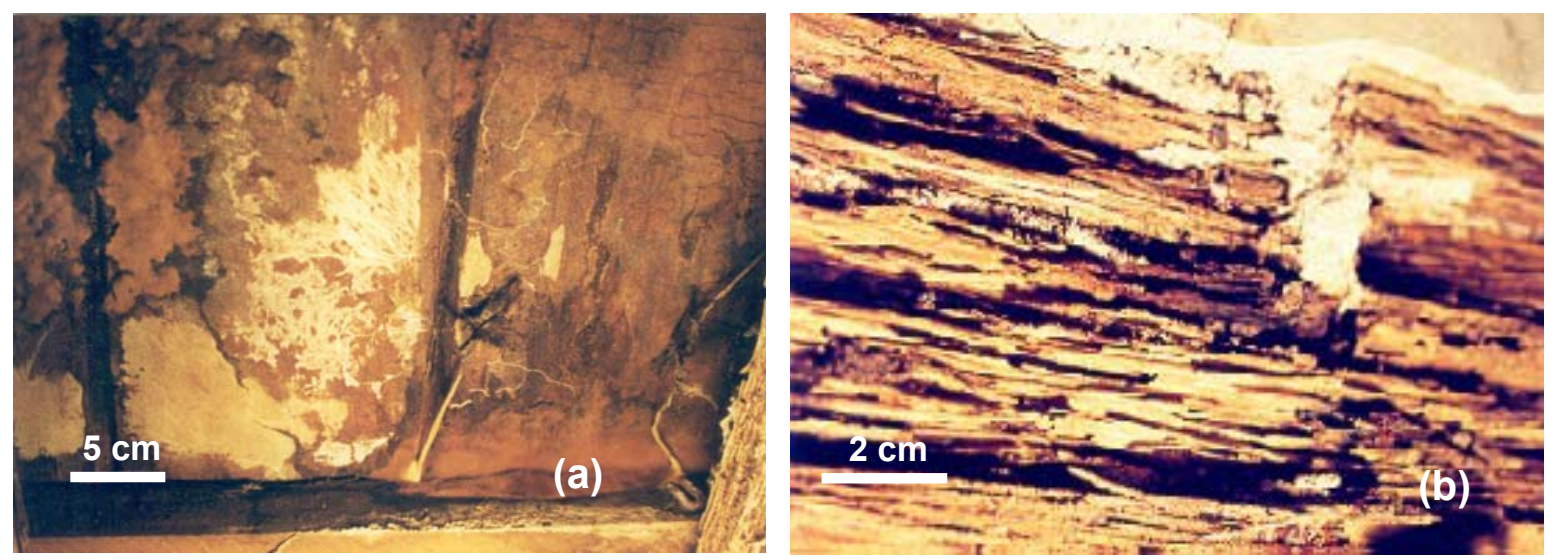

Figura 6. 2 - Detalhe do madeiramento de suporte do piso superior e da juçara expostos pelo desabamento do forro com indícios da biodeterioração por diversos microorganismos e pela presença de cupins na mapoteca (cômodo T10): (a) observa-se frutificações e micélio de fungos no madeiramento de suporte do assoalho do piso superior; (b) detalhe de quatro ripas de juçara com galerias no seu interior.

\subsubsection{Pavimento superior}

Durante a retirada de amostras pelo sótão do cômodo S10, observou-se que a região das amostras S10A e S10B não foi armada com juçara, mas com ripas de madeira, e que não apresentava a camada superior de argamassa comum a todas as outras regiões do forro em estuque. A Figura 6.3 a mostra a vista desta região, à esquerda da fotografia pode-se observar a parte do forro armado com ripas de juçara, recobertas por argamassa, e no restante a região armada com ripas de madeira. A Figura $6.3 \mathrm{~b}$ apresenta as ripas de madeira, que se encontravam íntegras, com alta resistência ao corte com formão.

As ripas e caibros de suporte do forro em estuque encontram-se fixadas ao madeiramento de suporte do telhado (terças). A viga dupla em madeira observada 
transversalmente na Figura 6.3 pertence a uma das terças do telhado. Como já exposto na bibliografia, essa condição favorece o aparecimento de fissuras por efeito de variação higrotérmica, que se caracterizam por serem regularmente espaçadas e transversais umas as outras. Fissuras desse tipo foram observadas com grande incidência no forro em estuque da edificação Vila Penteado (vide fotos do forro nos cômodos S07, S09, S09B, S11B, S18, S19 e S20, no Anexo D desta dissertação).
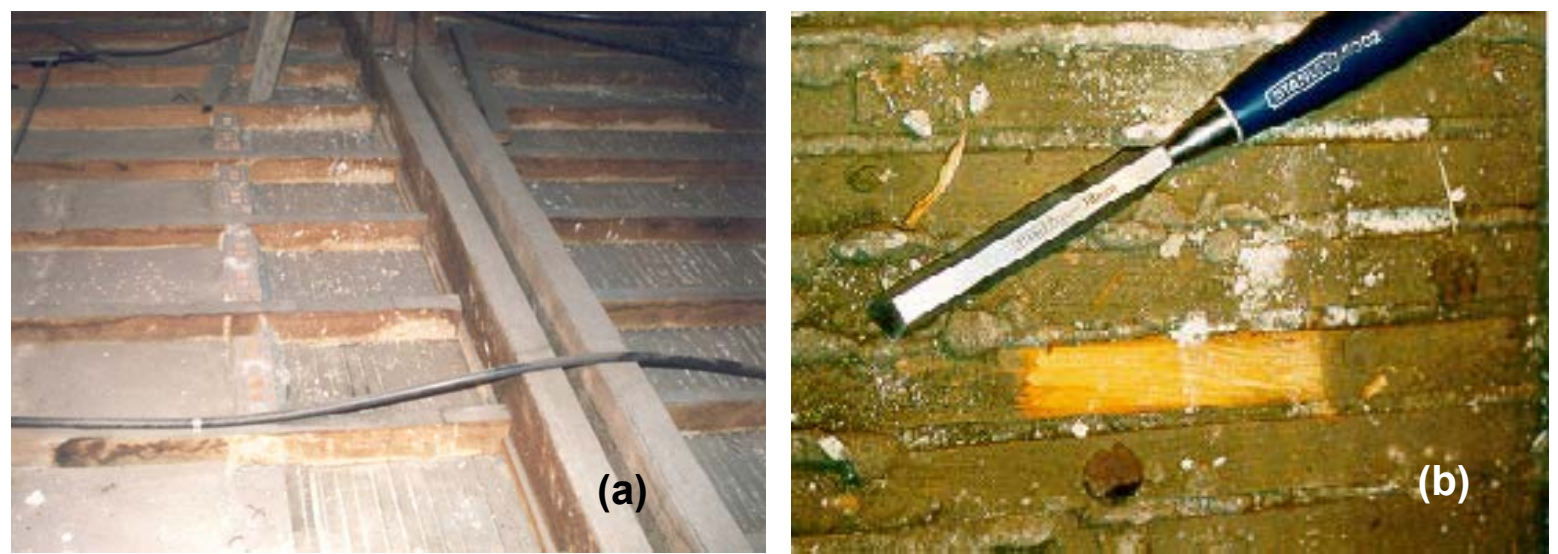

Figura 6. 3 - Vista do forro em estuque pelo sótão. (a) camada de argamassa que reveste a juçara (lado esquerdo da foto) e utilização de madeira alternativa à juçara não revestida pela argamassa na região das amostras S10A e S10B (esquerda da foto); (b) detalhe da madeira alternativa à juçara.

As ripas de juçara encontravam-se ora de difícil corte, saindo somente pedaços superficiais, como ocorrido no local ilustrado pela Figura 6.4 a; ora desfibrando inviabilizando a coleta de amostras, evidenciado na Figura $6.4 \mathrm{~b}$; ora bastante apodrecidas. 

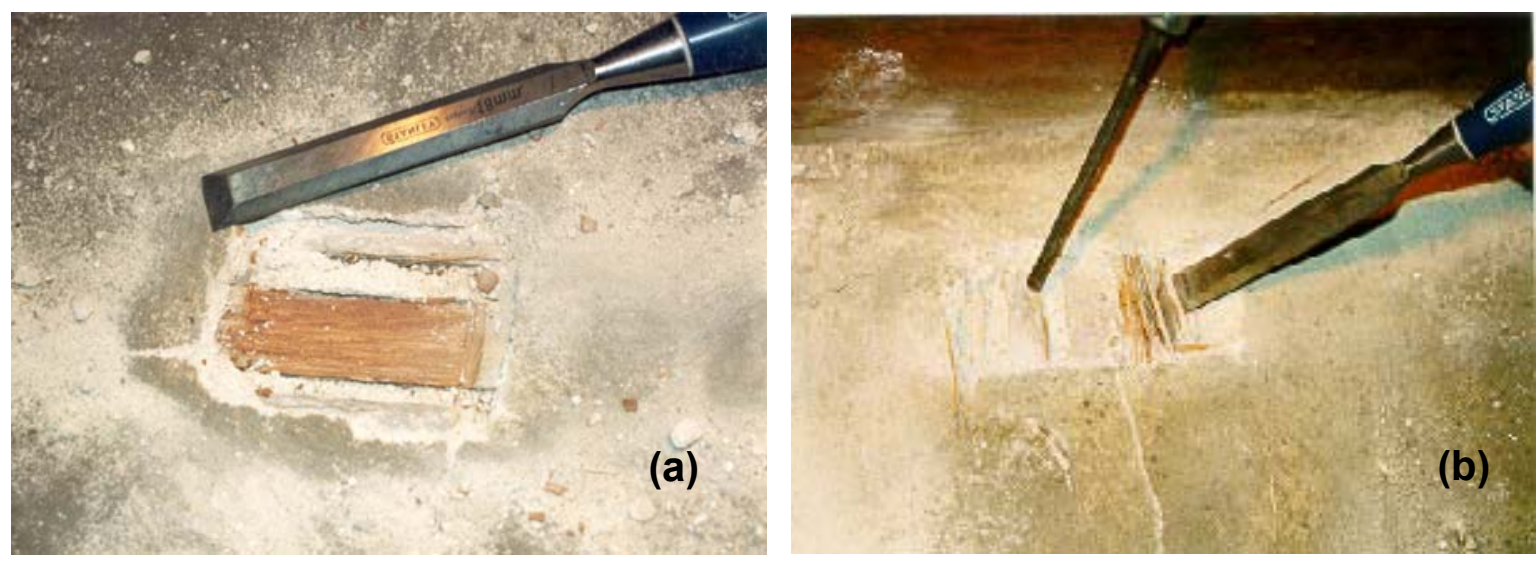

Figura 6. 4 - Estado das ripas de juçara: diferentes comportamentos quando submetidas ao corte com serra manual e formão; (a) amostra de juçara de difícil corte; (b) desfibramento da ripa de juçara devido ao corte.

As amostras de argamassa coletadas pelo sótão nos cômodos S11, S12 e S12B apresentaram maior dificuldade de corte que as amostras de argamassa coletadas, também pelo sótão, nos cômodos S10, S09 e S09B.

Pelo sótão observou-se intenso apodrecimento da amostra de juçara $\mathrm{S}_{11 \mathrm{Cj}}{ }^{6.1}$, caracterizando-se por ser a amostra de maior ataque. A face inferior do forro, visível pelo cômodo S11, encontrava-se escorada por uma placa de compensado com mancha de infiltração, porém nenhum indício de biodeterioração foi observado no revestimento após a abertura na placa (Figura 6.5). Dentre as amostras de argamassa enviadas para o isolamento e identificação dos fungos, a amostra S11A foi a coletada mais próxima dessa região.

${ }^{6.1}$ A juçara encontrava-se tão apodrecida que não foi possível realizar a avaliação da sanidade biológica em laboratório. 


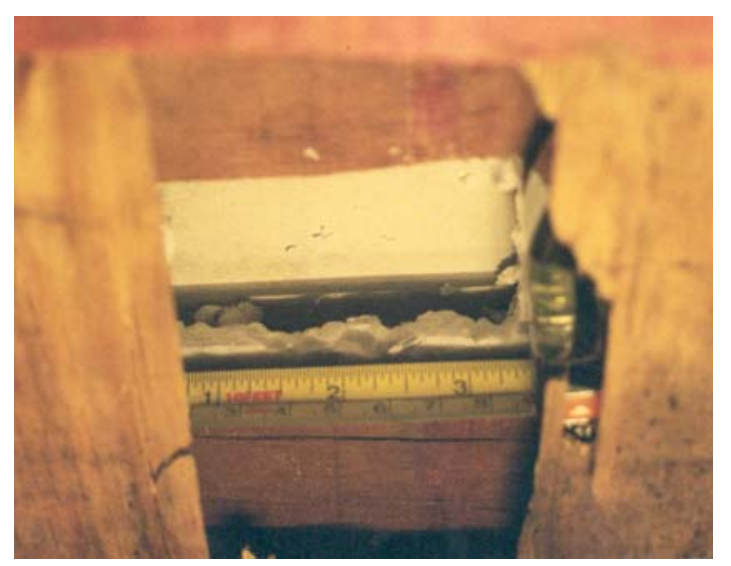

Figura 6. 5 - Face inferior do forro, após a abertura na placa de compensado, sem indícios de biodeterioração no revestimento.

Situação semelhante ocorreu na região da coleta das amostras S19A e S19Aj. Apesar da deterioração intensa do forro ser visível pelo sótão, a face inferior do forro não apresentava sinais de deterioração muito evidentes. As Figuras 4.4 e 4.5, do Capítulo 4, mostraram esta região antes e durante a coleta de amostras. A fissura observada na Figura 4.4 à direita limitava-se ao sistema de pintura.

\subsection{Análise de caracterização e avaliação microestrutural da argamassa em laboratório}

\subsubsection{Análise por difração de raios X (DRX)}

A análise por difração de raios-X mostrou picos de maior intensidade para o quartzo. A composição mineralógica das argamassas é constituída, além do quartzo, também por calcita (carbonato de cálcio), magnesita (carbonato de magnésio), brucita (hidróxido de magnésio), dolomita (carbonato de cálcio e magnésio), feldspato-microclínio, caulinita e mica (muscovita). A presença de compostos de magnésio é um indicativo de que a natureza da cal é dolomítica. 
Nas amostras deterioradas T10D e S19A não foram evidenciados picos de brucita nos difratogramas.

Nas amostras T18X (amostra T18C beneficiada), S10D, S10F foram encontrados dois picos principais de periclásio (óxido de magnésio). No entanto, por ser uma fase muito instável nas condições de exposição, com grande possibilidade de hidratação, decidiu-se desprezar esta informação. Os resultados da análise por DRX estão apresentados no Anexo G.

O beneficamento das amostras teve pouca influência na minoração da intensidade dos picos de quartzo.

\subsubsection{Análise química}

Os resultados da análise química e a proporção aglomerante : agregado das amostras S19C (região sã), T10D e S19A (regiões deterioradas) encontram-se na Tabela 6-1.

Tabela 6 - 1 Resultados da análise química (base não volátil)

\begin{tabular}{|c|c|c|c|c|c|c|c|c|c|c|}
\hline \multirow[t]{2}{*}{ Amostras } & \multicolumn{9}{|c|}{ Constituintes, em (\%) } & \multirow{2}{*}{$\begin{array}{c}\text { aglomerante } \\
\text { agregado } \\
\text { (em massa) }\end{array}$} \\
\hline & $\mathbf{U m}$ & PF & RI & $\mathrm{SiO}_{2}$ & $\mathbf{R}_{2} \mathbf{O}_{3}$ & $\mathrm{CaO}$ & MgO & $\mathrm{SO}_{3}$ & $\mathrm{CO}_{2}$ & \\
\hline $\begin{array}{c}\text { S19C } \\
\text { região sã }\end{array}$ & 0,62 & 9,86 & 77,8 & 0,38 & 0,30 & 6,66 & 4,38 & 0,05 & 6,78 & $1: 6,5$ \\
\hline $\begin{array}{c}\text { S19A } \\
\text { região deteriorada }\end{array}$ & 0,26 & 11,4 & 76,8 & 0,55 & 0,42 & 6,82 & 4,01 & 0,01 & 8,58 & $1: 6,7$ \\
\hline $\begin{array}{c}\text { T10D } \\
\text { região deteriorada }\end{array}$ & 0,76 & 15,6 & 70,3 & 0,43 & 0,50 & 8,07 & 5,14 & 0,01 & 13,8 & $1: 5,0$ \\
\hline
\end{tabular}

A proporção aglomerante:agregado foi expressa considerando a utilização de cal virgem. Os dados da análise química indicaram uma relação $\mathrm{CaO}: \mathrm{MgO}$ característica de um dolomito empregado como matéria-prima, coerentemente com a hipótese formulada pelo resultado da análise por difração de raios X. Os maiores teores de anidrido 
carbônico $\left(\mathrm{CO}_{2}\right)$ das amostras S19A e T10D indicam uma maior carbonatação das regiões deterioradas, refletindo no resultado de perda ao fogo (PF).

\subsubsection{Análise petrográfica}

A Tabela 6-2 resume os principais aspectos petrográficos observados nas amostras.

Tabela 6 - 2 Resultados da análise petrográfica

\begin{tabular}{|c|c|c|c|c|}
\hline \multirow[t]{2}{*}{ Parâmetros analisados } & \multicolumn{2}{|c|}{ Regiões sãs } & \multicolumn{2}{|c|}{ Regiões deterioradas } \\
\hline & Amostra T04A & Amostra S19C & Amostra T10D & Amostra S19A \\
\hline Agregado $(*)$ & $65-70 \%$ & $65-70 \%$ & $50-55 \%$ & $60-65 \%$ \\
\hline Variação granulométrica & $0,09-2,50 \mathrm{~mm}$ & $0,09-3,20 \mathrm{~mm}$ & $0,09-2,50 \mathrm{~mm}$ & $0,09-3,20 \mathrm{~mm}$ \\
\hline Granulometria predominante & $\begin{array}{c}0,46-0,90 \mathrm{~mm} \\
\text { (areia média ) }\end{array}$ & $\begin{array}{c}1,80-3,00 \mathrm{~mm} \\
\text { (areia muito } \\
\text { grossa) }\end{array}$ & $\begin{array}{l}0,46-0,90 \mathrm{~mm} \\
\text { (areia média ) }\end{array}$ & $\begin{array}{l}1,80-3,00 \mathrm{~mm} \\
\text { (areia muito } \\
\text { grossa) }\end{array}$ \\
\hline Pasta & $10-15 \%$ & $10 \%$ & $20-25 \%$ & $15-20 \%$ \\
\hline $\begin{array}{l}\text { Vazios: } \\
\text { Formas arredondadas (ar } \\
\text { incorporado); formas alongadas } \\
\text { (comunicados entre si); } \\
\text { microfissuras (comuns na } \\
\text { pasta) }\end{array}$ & $20 \%$ & $20-25 \%$ & $25 \%$ & $20 \%$ \\
\hline
\end{tabular}

Ressalta-se a diferença entre a granulometria predominante entre as amostras de argamassa coletadas na camada inferior do forro em estuque do pavimento térreo (T04A e T10D) e as amostras S19C e S19A, coletadas na camada sobre as ripas de juçara do pavimento superior, acessíveis pelo sótão.

As amostras de argamassa T04A e T10D provêm da camada inferior do forro em estuque e possuem granulometria predominante na faixa de areia média, comumente utilizada em argamassas de acabamento. As amostras S19C e S19A provém da camada superior do forro em estuque, não ficando aparente e, provavelmente, com a única função de proteção das ripas, o que justifica a utilização de areia muito grossa.

Diferentemente ao esperado, a redução do teor de agregados nas amostras deterioradas T10D e S19A não refletiu no aumento de vazio, tendo sido observado o aumento do teor de pasta. 


\subsubsection{Descrição das fases}

a) Agregado

Os grãos que compõem o agregado não diferem muito dentre as amostras estudadas (Figuras 6.6 a 6.9), sendo provavelmente provenientes do mesmo sítio geológico. Os grãos são aproximadamente equidimensionais, angulosos a subangulosos. Em todas as amostras o agregado é constituído por quartzo monocristalino (90\%); feldspatos microclínio e plagioclásio (5\%); e a fração restante por quartzo policristalino, mica (muscovita), fragmentos de solo argiloso, turmalina, estaurolita e zircão (5\%). Os feldspatos acham-se levemente alterados (Figura 6.7 a, indicado pela letra f), apresentando uma certa porosidade ao longo dos planos de clivagens.

\section{b) Pasta}

A pasta encontra-se praticamente restrita ao contorno do agregado, raramente ocorrendo em formas mais densas, como exemplificado na Figura 6.6 c.

c) Vazios

Foram observadas feições interessantes em relação às descontinuidades físicas das amostras.

Nas amostras coletadas em regiões não deterioradas (T04A e S19C) observam-se claramente pelo menos 3 tipos de vazios:

- vazios com seções arredondadas (Figura 6.6 b, indicado pela letra v), com diâmetro submilimétrico a milimétrico: provavelmente devido ao ar aprisionado da mistura; 
- vazios alongados, com comprimentos milimétricos e espessura submilimétrica (Figura 6.6 a, indicado pela letra v), comunicados entre si, abundantes principalmente na amostra S19C;

- vazios "bidimensionais" (microfissuras) na pasta, comuns nas duas amostras (exemplificado na Figura 6.7 c).

$\mathrm{Na}$ amostra T10D predominam os vazios "bidimensionais", sendo estes milimétricos a centimétricos (Figura 6.8 a, indicado pela letra v), enquanto na amostra S19A os vazios são micrométricos a submilimétricos, com seções arredondadas ou irregulares, distribuídos homogeneamente em praticamente toda a amostra, oriundos provavelmente de grãos de agregado arrancados (Figura 6.9 a, indicado pela letra v.

Nas amostras T10D e S19A, coletadas em regiões deterioradas, foi observada a ocorrência de carbonatação restrita e localizada, utilizando polarizadores cruzados. A Figura 6.9 mostra a mesma imagem da amostra S19A, sendo apresentado na Figura 6.9 a a imagem obtida com polarizadores descruzados e na Figura 6.9 b com polarizadores cruzados, onde foram observados cristais micrométricos e birrefringentes de carbonato justapostos destacando-se do restante da pasta.

As imagens seguintes ilustram os principais aspectos observados na análise petrográfica. 

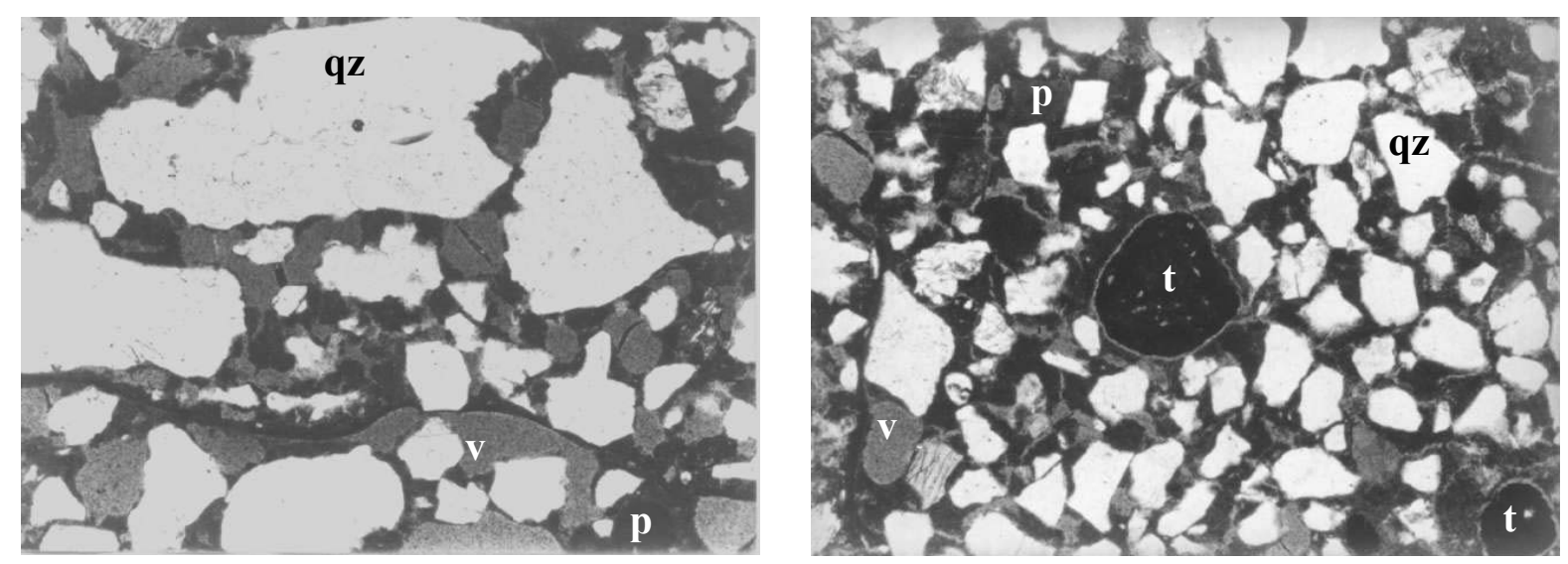

(a)

(b)

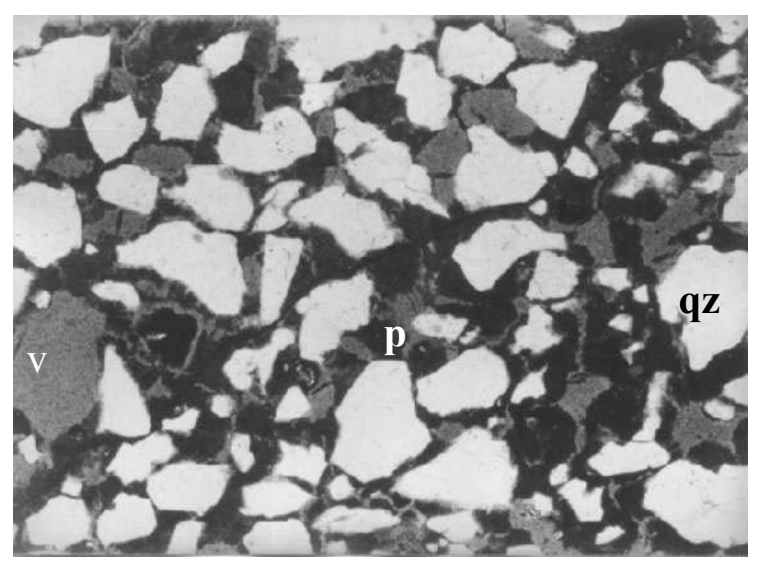

Legenda: $\mathrm{p}$ - pasta; qz - quartzo; v - vazios; $\mathrm{t}$ - torrão de argila.

(c)

Figura 6. 6 - Fotomicrografia da amostra T04A, não deteriorada. Aspecto geral da amostra, com polarizadores descruzados, observando-se: pasta (p), em preto; vazios (v) em cinza; agregado predominantemente quartzoso (qz) em branco; e torrões de argila (t) com forma arredondada, em preto com borda acinzentada. Aumento utilizado: $22 x$. 

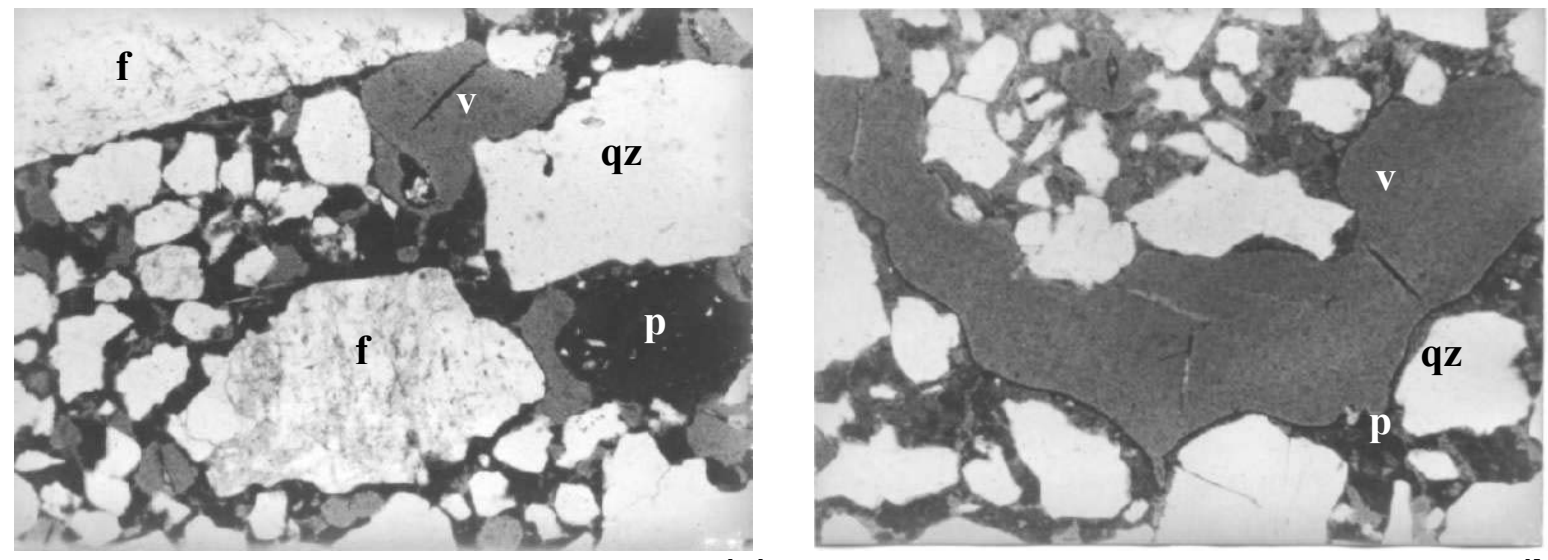

(a)

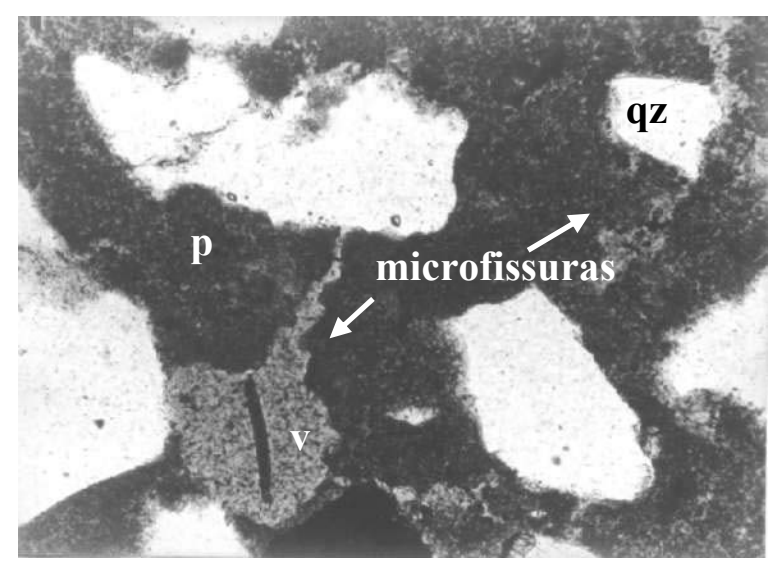

Legenda: $\mathrm{p}$ - pasta; qz - quartzo; v - vazios; $\mathrm{f}$ - feldspato;

(c)

Figura 6. 7 - Fotomicrografia da amostra S19A, não deteriorada. Aspectos observados na amostra com polarizadores descruzados: pasta (p) em preto; vazios (v) em cinza; agregado predominantemente quartzoso (qz), em branco e feldspato levemente alterado (f), rajado. Aumentos utilizados: fotomicrografias (a) e (b) $22 \times$ e fotomicrografia (c) $87 x$. 

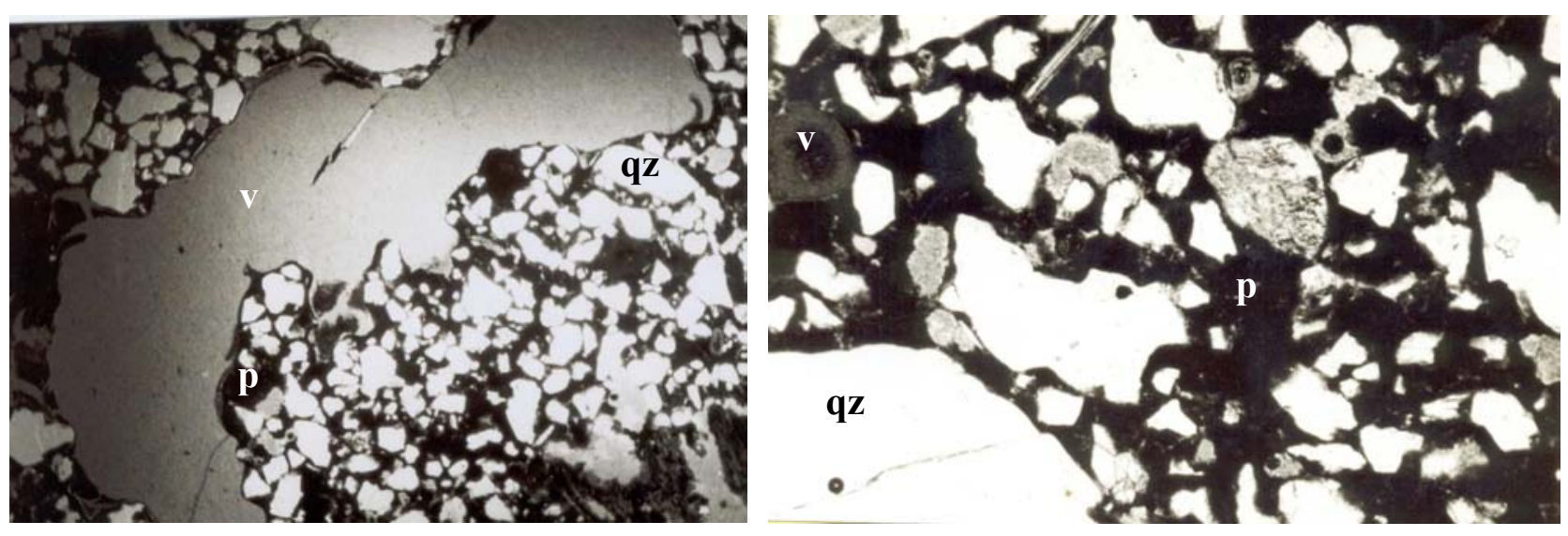

(a)

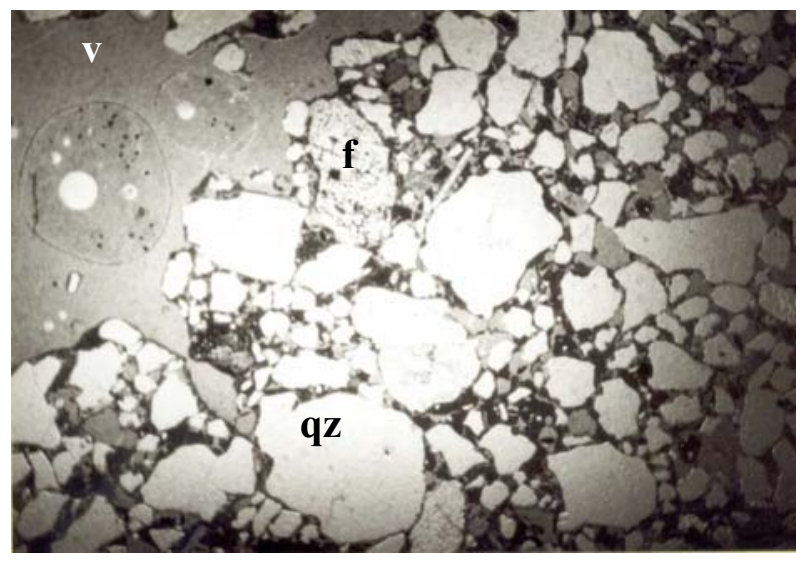

Legenda: $\mathrm{p}$ - pasta; qz - quartzo; $\mathrm{v}$ - vazios; $\mathrm{f}$ - feldspato

(c)

Figura 6. 8 - Fotomicrografia da amostra T10D, deteriorada (amostra do entorno da região do forro em estuque colapsada). Aspectos observados na amostra com polarizadores descruzados: pasta (p), em preto; vazios (v), em cinza; agregado predominantemente quartzoso (qz), em branco e feldspato alterado (f), rajado. Aumentos utilizados: fotomicrografia (a) $7 \mathrm{x}$; e fotomicrografias (b) e (c) $22 \mathrm{x}$. 

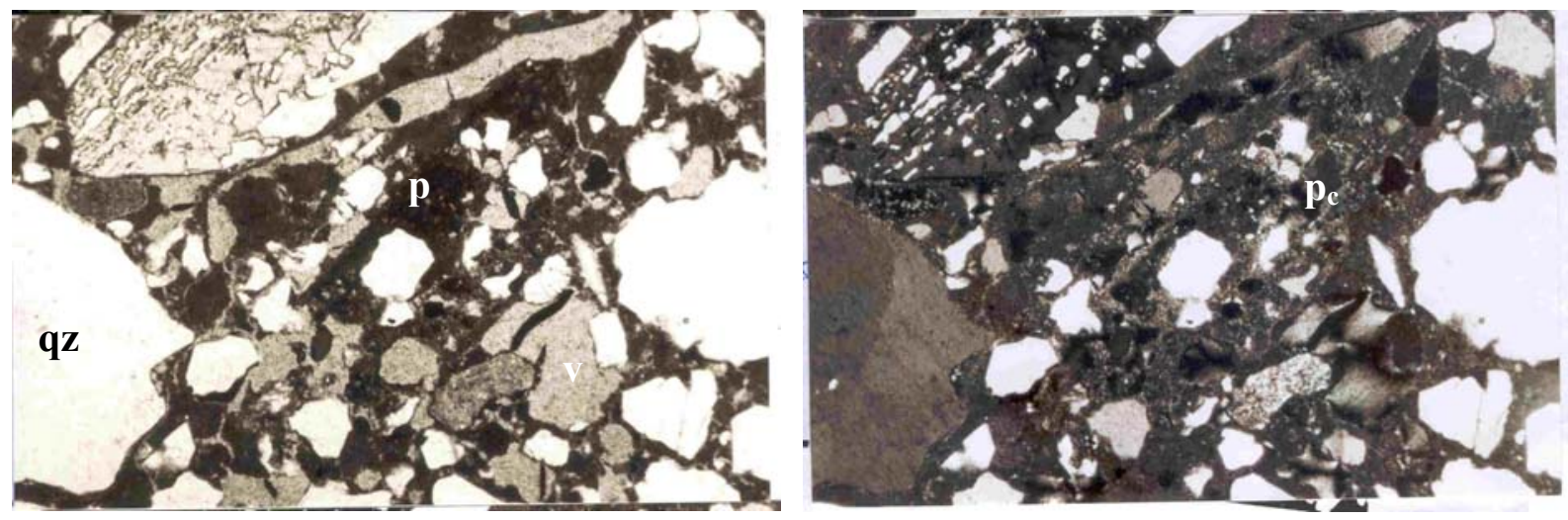

(a)

(b)

Legenda: $\mathrm{p}$ - pasta; $\mathrm{qz}$ - quartzo; $\mathrm{v}$ - vazios; $\mathrm{p}_{\mathrm{c}}$ - pasta carbonatada

Figura 6.9-Fotomicrografia da amostra S19A, deteriorada: (a) com polarizadores descruzados e (b) com polarizadores cruzados, o que possibilitou verificar a carbonatação restrita e localizada na pasta. Aumento utilizado: 22 x.

\subsubsection{Microscopia eletrônica de varredura (MEV)}

Os aspectos microestruturais apresentados e descritos a seguir foram observados em microscopia eletrônica de varredura nas amostras T04A e S19C, coletadas em regiões sãs. A Figura 6.10 apresenta as imagens obtidas da amostra T04A.

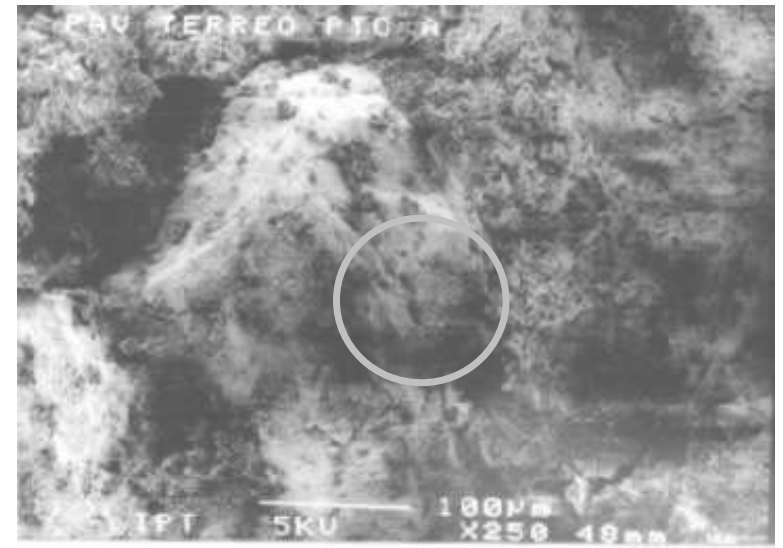

(a)

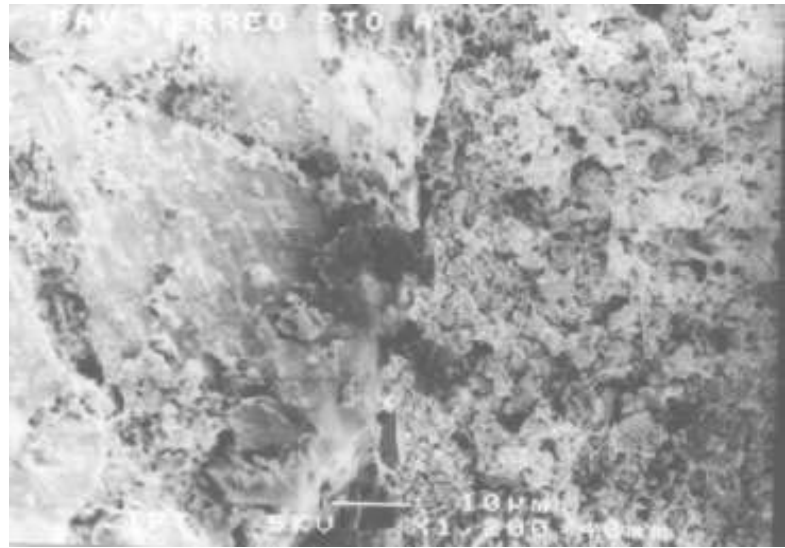

(b)

Figura 6. 10 - Fotomicrografias da amostra T04A, não deteriorada. (a) aspecto de um grão de quartzo do agregado envolto pela pasta; (b) detalhe de fissura no grão de quartzo. 
A fotomicrografia a da Figura 6.10 evidencia um grão de quartzo do agregado de aproximadamente $200 \mu \mathrm{m}$ de diâmetro. Este grão é subanguloso e apresenta algumas trincas, vistas em detalhe na fotomicrografia $b$. Estas trincas possivelmente têm origem anterior à preparação da argamassa.

Ainda na fotomicrografia $a$, pode ser observado que à direita do grão de quartzo a argamassa apresenta variações de porosidade: a camada mais próxima do grão de quartzo, com aproximadamente $90 \mu \mathrm{m}$ de espessura, é significativamente mais porosa que a camada que lhe segue. No entanto, os diâmetros dos poros são aparentemente semelhantes em ambas camadas. A amostra apresenta poros grandes, da ordem de $100 \mu \mathrm{m}$ a tamanhos superiores a $500 \mu \mathrm{m}$, indicando a remoção de materiais previamente existentes, coerentemente com os aspectos observados na análise petrográfica quanto à variação granulométrica e aos tipos de vazios. Pode-se perceber também que os poros da pasta apresentam formatos irregulares, com diâmetros variando entre 1 e $5 \mu \mathrm{m}$.

A Figura 6.11 apresenta as imagens obtidas da amostra S19C.
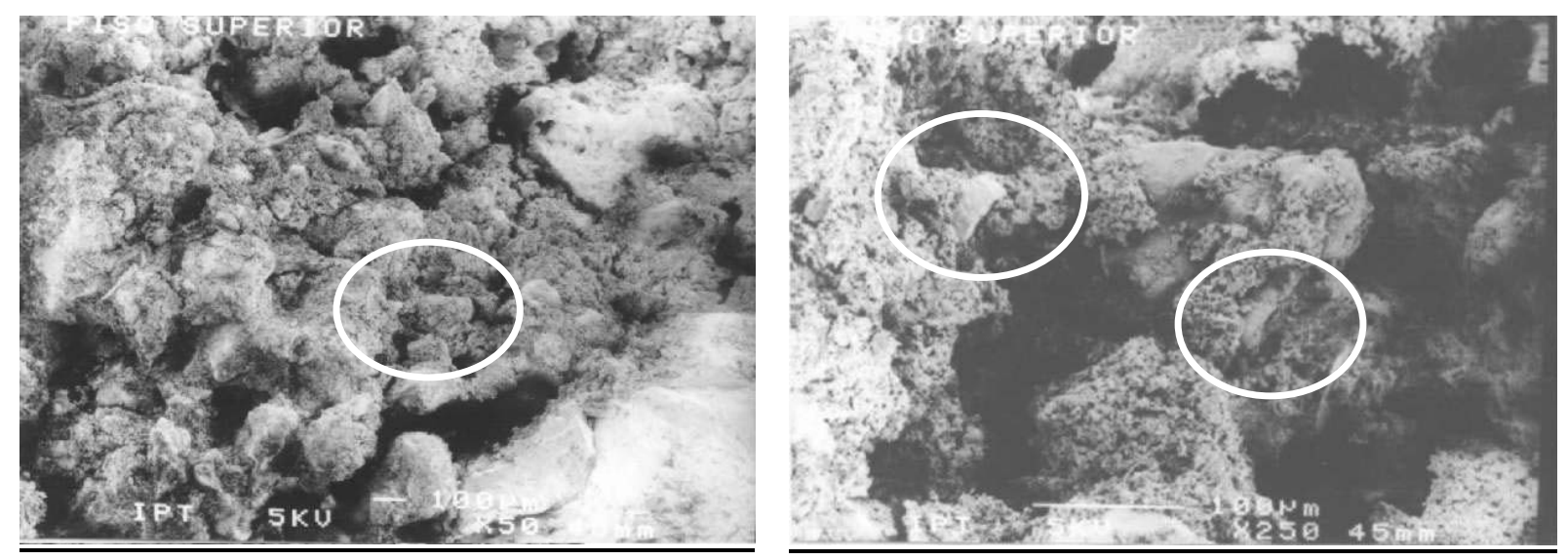

(a) 


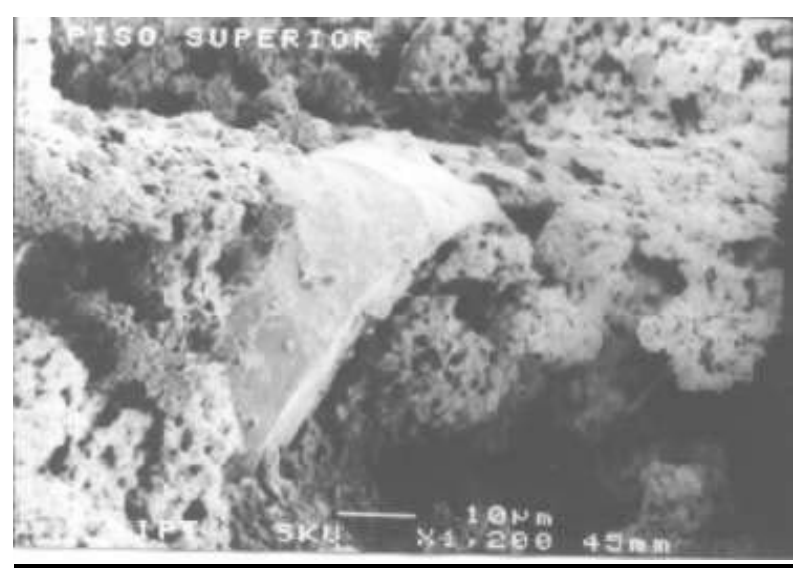

(c)

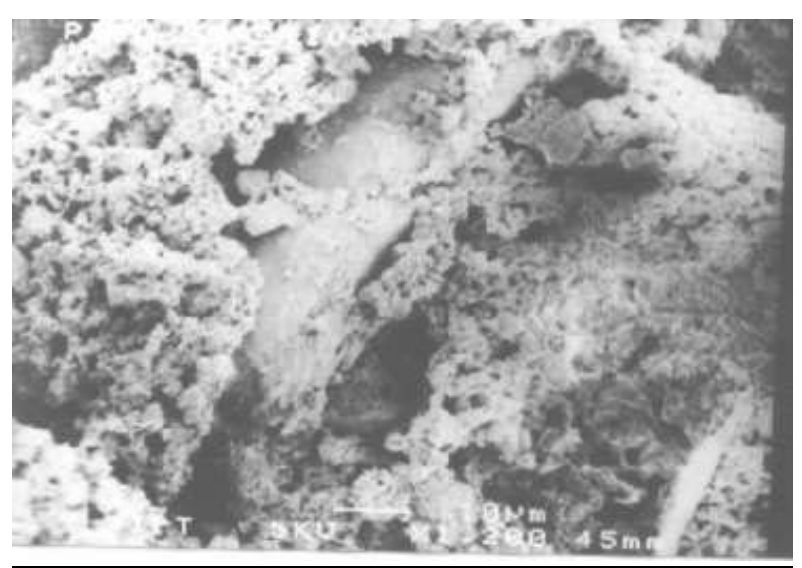

(d)

Figura 6. 11 - Fotomicrografias da amostra S19C, não deteriorada. (a) Aspecto geral da amostra observado pela microscopia eletrônica de varredura, evidenciando a porosidade; (b) aspecto da área assinalada na fotomicrografia a; (c) detalhe de um grão de feldspato, da pasta ao seu redor e dos vazios de interface; (d) detalhe de um grão de mica totalmente solto da pasta.

A fotomicrografia a da Figura 6.11 evidencia a porosidade da amostra S19C, maior que a da amostra T04A. Estes poros, também observados pela análise petrográfica, possuem mais de $200 \mu \mathrm{m}$ de diâmetro e são intercomunicantes, como pode ser visto na fotomicrografia $b$. A fotomicrografia c mostra um detalhe de feldspato, evidenciado pelas superfícies de clivagem. A aderência da pasta ao grão é muito baixa, ocorrendo poros muito longos que o envolvem e destacam-no da pasta. A fotomicrografia d exibe um grão de mica quase totalmente solto da pasta que o envolve. A pasta é bastante porosa, com poros de diâmetro variando também de $1 \mu \mathrm{m}$ a até mais de $5 \mu \mathrm{m}$.

\subsubsection{Porosidade das amostras}

A Tabela 6-3 apresenta valores obtidos a partir da determinação dos seguintes parâmetros: volume aparente $\left(\mathrm{V}_{\text {apar. }}\right)$ medido com paquímetro; massa $(\mathrm{m})$ obtida em balança analítica; volume real $\left(\mathrm{V}_{\text {he }}\right)$ obtido por picnometria de hélio e volume de poros $\left(\mathrm{V}_{\mathrm{p}}\right)$ obtido por porosimetria por intrusão de mercúrio. 
Tabela 6-3 Resultados da porosidade das amostras coletadas em regiões sãs

\begin{tabular}{l|c|c}
\hline \multicolumn{1}{c|}{ Parâmetros } & \multicolumn{2}{c}{ Resultados } \\
\cline { 2 - 3 } & S19C & T04A \\
\hline \hline Massa específica aparente $\left(\mathrm{g} / \mathrm{cm}^{3}\right)$ & 1,18 & 1,40 \\
\hline Massa específica real $\left(\mathrm{g} / \mathrm{cm}^{3}\right)$ & 2,64 & 2,64 \\
\hline Volume de poros por intrusão de mercúrio $\left(\mathrm{cm}^{3} / \mathrm{g}\right)$ & 0,18 & 0,16 \\
\hline Volume de poros por intrusão de mercúrio $(\%)$ & 21 & 22 \\
\hline Volume específico de poros $\left(\mathrm{cm}^{3} / \mathrm{g}\right)$ & 0,47 & 0,33 \\
\hline Volume de poros não mensurável por intrusão de mercúrio $\left(\mathrm{cm}^{3} / \mathrm{g}\right)$ & 0,29 & 0,17 \\
\hline
\end{tabular}

A Tabela 6-3 mostra que o volume de poros não mensuráveis por porosimetria de mercúrio da amostra $\mathrm{S} 19 \mathrm{C}\left(0,29 \mathrm{~cm}^{3} / \mathrm{g}\right)$ é consideravelmente maior do que o da amostra T04A $\left(0,17 \mathrm{~cm}^{3} / \mathrm{g}\right)$. Como a faixa de detecção da porosimetria de mercúrio, para as condições utilizadas, varia entre $500 \mu \mathrm{m}$ e $0,0035 \mu \mathrm{m}$, existe uma grande quantidade de poros maiores que $500 \mu \mathrm{m}$ nas amostras, sobretudo na amostra S19A, que devem corresponder aos poros intercomunicantes observados pela análise petrográfica e pela microscopia eletrônica de varredura.

As Figuras 6.12, 6.13 e 6.14 mostram, respectivamente, a distribuição da porosidade acumulada (P), a comparação entre a porosidade acumulada $\mathrm{P}(\%)$ das amostras analisadas e os histogramas de porosidade $\mathrm{P}(\%)$ de acordo com classes relativas à provável gênese dos poros mensuráveis pela porosimetria por intrusão de mercúrio.

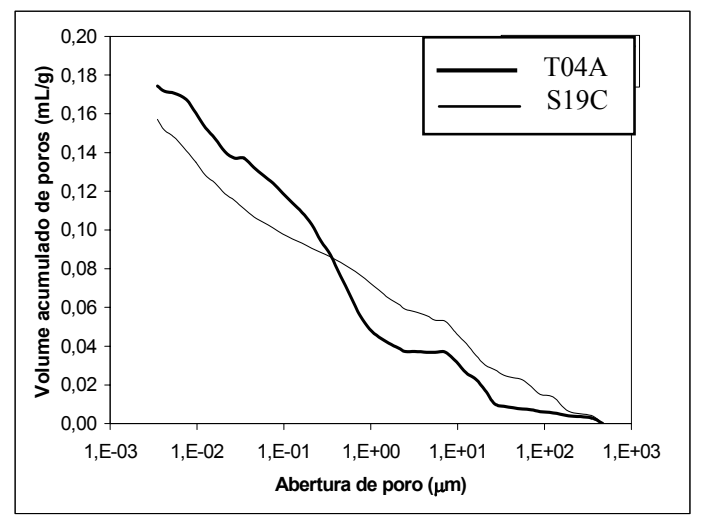

Figura 6. 12 - Porosidade acumulada. 


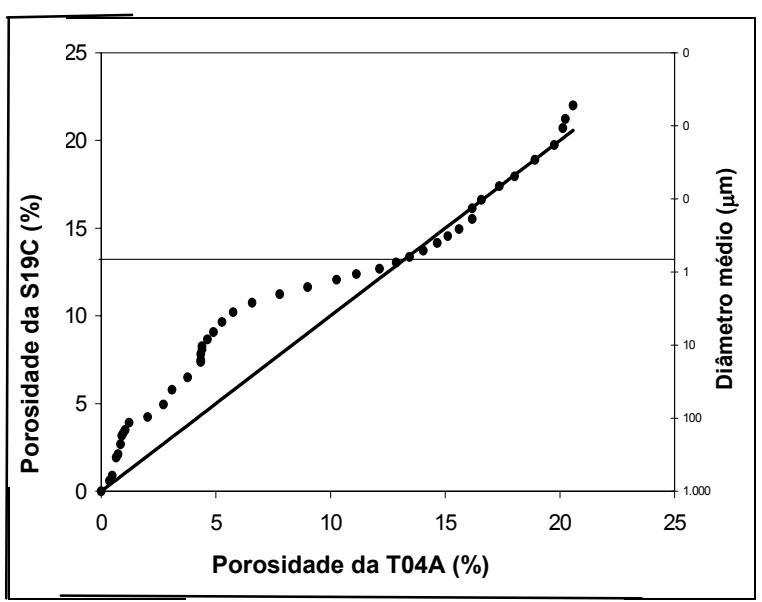

Figura 6. 13 - Análise comparativa dos poros.

Na Figura 6.12 está evidenciado que o aumento do volume de poros da amostra S19C é praticamente uniforme para a faixa de poros analisada. Este comportamento não ocorreu na amostra T04A, pois são verificados patamares na curva.

Já a Figura 6.13 evidencia que a amostra S19C se apresentou mais porosa que a T04A para a faixa que compreende os diâmetros de poros maiores que $1 \mu \mathrm{m}$ (macroporos). Os poros menores que $1 \mu \mathrm{m}$ possuem formas e distribuições semelhantes nas duas amostras. A Figura 6.14 mostra os histogramas de porosidade, divididos por faixas de diâmetro associadas à sua gênese. Adotou-se que:

- $\quad$ poros maiores que $10 \mu \mathrm{m}=$ ar aprisionado ou incorporado;

- poros entre 1 e $10 \mu \mathrm{m}=$ vazios de interfaces e;

- $\quad$ poros menores que $1 \mu \mathrm{m}=$ vazios.

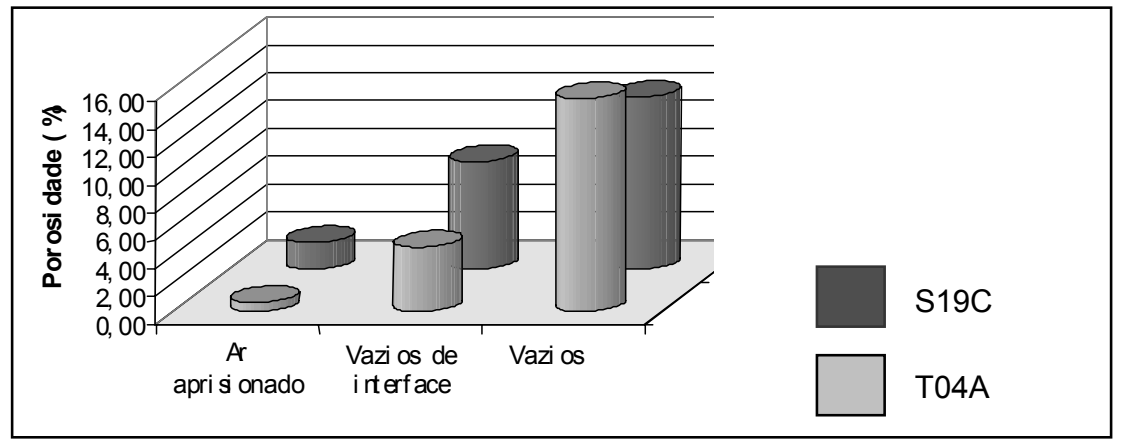

Figura 6. 14 - Histograma de porosidade mensurável por intrusão de mercúrio. 
Os histogramas mostram que a amostra T04A tem uma quantidade ligeiramente maior de vazios (poros menores que $1 \mu \mathrm{m}$ ) que a amostra S19C. Por outro lado, os vazios de interface e de ar aprisionado são maiores na amostra S19C.

\subsubsection{Considerações sobre a caracterização e a avaliação microestrutural das amostras de argamassa}

A caracterização e a avaliação microestrutural foram realizadas em amostras de argamassa coletadas em regiões sãs e deterioradas, de modo a obter parâmetros a serem utilizados para elaboração da proposta de intervenção e inferir sobre os agentes e mecanismos de deterioração.

Quanto à composição da argamassa original:

- Os dados da análise química indicaram a utilização de agregado silicoso (insolúvel em meio ácido) e de cal dolomítica como único aglomerante.

Os dados da análise petrográfica e os difratogramas corroboram esta afirmação. No que tange aos:

a) agregados

A análise petrográfica mostrou que o agregado é predominantemente quartzoso e descartou a hipótese de adições de argilas. A caulinita, mica (muscovita) e feldspato identificados pelo difratograma são, provavelmente, oriundos da areia, dado os baixos teores obtidos pela análise petrográfica e o teor $\mathrm{R}_{2} \mathrm{O}_{3}$ obtido pela análise química.

b) aglomerante

A presença de dolomita, brucita e calcita no difratograma reforçam a atribuição de cal dolomítica como aglomerante. A presença de dolomito, matéria-prima remanescente do processo produtivo, indica ausência de controle de qualidade, 
como era comum no início do século XX, quando o processo de produção de cal resultava em cales com altos teores de material carbonático residual após a calcinação. Entre as cales atuais, a tipo CH III é a mais próxima dessa característica, pois se admite para este material que o teor de $\mathrm{CO}_{2}$ residual seja de até $13 \%$ na fábrica.

A ausência de silicatos hidratados nos difratogramas de raios X descarta a possibilidade de ter sido empregado aglomerante hidráulico.

Da mesma forma, a ausência de picos de gipsita nos difratogramas e também os baixos teores de sulfatos determinados na análise química, descartam a utilização de gesso nas argamassas analisadas. Isto contradiz a afirmação sobre a utilização de uma argamassa de gesso apresentada na carta encaminhada à FAUUSP pelo Prof. Dr. Antonio Luiz Dias de Andrade em julho de 1994, e indica que não se aplica a este estudo as informações dos manuais de construção do século passado que prescrevem a utilização de argamassas mistas de cal e gesso em forros de estuque (RAINVILLE, 1880).

Os dados da análise química indicaram maiores teores de carbonatos nas amostras deterioradas. Estes resultados foram corroborados pela identificação de carbonatação pela análise petrográfica.

Quanto à microestrutura das amostras de argamassa coletadas em regiões não deterioradas:

A quantificação da diferença de porosidade entre as amostras T04A e S19C revelada pela porosimetria por intrusão de mercúrio foi pouco expressiva, sendo que esta técnica limita-se a poros inferiores a $500 \mu \mathrm{m}$. Por outro lado, o volume de poros mensuráveis 
por técnicas auxiliares foi significativamente maior na amostra S19C, como mostra a Figura 6.15.

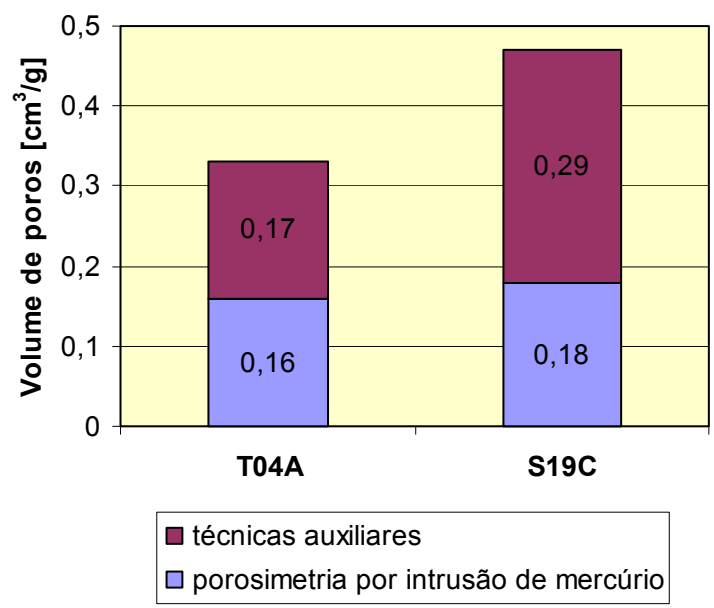

Figura 6. 15 - Porosidade das amostras T04A e S19C: comparação entre dados mensuráveis pela porosimetria por intrusão de mercúrio e mensuráveis por técnicas auxiliares.

A Figura 6.15 mostra que a diferença entre a porosidade das amostras deve-se aos poros com diâmetro superior a $500 \mu \mathrm{m}$, evidenciados pela análise petrográfica e pela observação por microscopia eletrônica de varredura.

Ressalta-se que a quantificação de poros pela análise petrográfica não evidenciou diferença significativa entre a porosidade das amostras como a porosimetria por intrusão de mercúrio e as suas técnicas auxiliares. Esta diferença entre as técnicas pode ser atribuída à escala de observação da análise petrográfica $(>0,05 \mu \mathrm{m})$ ou por esta quantificação ser por meio de régua graduada de uma seção transversal da amostra, ou seja, uma avaliação bidimensional, enquanto a quantificação pela porosimetria e técnicas auxiliares é volumétrica.

Considerando a observação pela microscopia eletrônica de varredura e o histograma de porosidade (Figura 6.14), a diferença da estrutura porosa entre as amostras deve-se preferencialmente ao aumento da quantidade e/ou profundidade dos poros originados 
pela incorporação de ar ou dos vazios de interface $(>1 \mu \mathrm{m})$. Caso o aumento da porosidade tenha ocorrido predominantemente pela profundidade dos poros, numa quantificação bidimensional não é possível mostrar esta diferença.

A diferença de porosidade entre as amostras T04A e S19C pode ser decorrente da própria execução e aplicação da argamassa ou de seu envelhecimento.

É importante considerar que:

A amostra S19C foi coletada na camada de argamassa sobre as ripas de juçara do forro em estuque do segundo pavimento da edificação, enquanto a amostra T04A foi coletada na camada sob as ripas de juçara do forro em estuque do pavimento térreo. Portanto, as argamassas têm funções diferentes, estando a amostra S19C mais exposta aos agentes de deterioração.

Como mostrou a análise petrográfica, as duas argamassas foram feitas com areia de mesma natureza, mas com granulometria predominante diferente. Na amostra T04A foi identificada a utilização de areia média $(0,46-0,90 \mathrm{~mm})$, enquanto na amostra S19C foi identificada a utilização de areia muito grossa $(1,80-3,00 \mathrm{~mm})$. Esta diferença deve-se, possivelmente à função de cada uma dessas camadas de revestimento. A função da camada de argamassa sob as ripas de juçara do forro em estuque é de acabamento e, muitas vezes de suporte de pinturas murais, requerendo textura lisa. Por sua vez, a função da camada de argamassa sobre as ripas é a proteção mecânica destas e ancoragem da camada de argamassa inferior, não ficando aparente e por isso sem função estética.

A edificação Vila Penteado é centenária e mesmo que as amostras S19C e T04A tenham sido coletadas em regiões consideradas sãs, estas podem encontrar-se num estágio inicial de deterioração, ainda não aparente. Considera-se também que a camada 
de argamassa onde foi coletada a amostra S19C, acessível pelo sótão, está mais exposta a infiltrações por água de chuvas, ainda que eventuais.

Corrobora a hipótese de estágio inicial de deterioração a observação por microscopia eletrônica de varredura, que identificou poros grandes, indicativos de arrancamento de material. Como a análise petrográfica mostrou que os menores tamanhos de grãos observados são da ordem de 0,09 $\mathrm{mm}(100 \mu \mathrm{m})$ em ambas amostras, a existência dos poros grandes observados no MEV (da ordem de $10 \mu \mathrm{m}$ a superiores a $500 \mu \mathrm{m}$ ) podem de fato indicar o arrancamento de grãos do agregado. Ressalta-se que a granulometria predominante da amostra T04A é de 0,46-0,90 mm (500 a $900 \mu \mathrm{m})$ e da S19C de 1,803,00 mm (1800 a $3000 \mu \mathrm{m})$. Para esta amostra é mais provável que o arrancamento de grãos esteja indicado pelos poros milimétricos observados pela análise petrográfica.

\subsection{Análise da biodeterioração}

\subsubsection{Isolamento e identificação de fungos na argamassa}

A Tabela 6-4 apresenta a relação dos fungos encontrados, juntamente com breve descrição do local de retirada das amostras. 
Tabela 6 - 4 - Resultados da identificação dos fungos presentes na argamassa

\begin{tabular}{c|c|l|c}
\hline Amostra & Registro ICB & Descrição do local de coleta da amostra & $\begin{array}{c}\text { Fungos } \\
\text { identificados }\end{array}$ \\
\hline \hline S12BA & $386 / 98$ & $\begin{array}{l}\text { Região seca, aparentemente pouco atacada, no } \\
\text { meio de uma trinca de grande abertura. (Escolhida } \\
\text { como referência para esta análise) }\end{array}$ & $\begin{array}{l}\text { Cladosporium sp. } \\
\text { Penicillium sp. }\end{array}$ \\
\hline S11A & $385 / 98$ & $\begin{array}{l}\text { Amostra retirada em cima do marco da porta, } \\
\text { região bastante deteriorada com fenda. Segundo } \\
\text { informação do funcionário de manutenção da } \\
\text { edificação, nesse local existiam problemas de } \\
\text { vazamento de água de chuva, antes da intervenção } \\
\text { no telhado. }\end{array}$ & Trichoderma sp. \\
\hline S19A & $409 / 98$ & $\begin{array}{l}\text { Amostra retirada com serra-copo, após localizar } \\
\text { deterioração avançada durante a vistoria pelo } \\
\text { sótão. }\end{array}$ & Trichoderma sp. \\
\hline T10A & $411 / 98$ & $\begin{array}{l}\text { Mapoteca - Amostra coletada em região } \\
\text { aparentemente não atacada, próximo ao local do } \\
\text { desabamento do forro. }\end{array}$ & Não identificado \\
\hline T10D & $429 / 89$ & $\begin{array}{l}\text { Mapoteca - Amostra retirada da argamassa do } \\
\text { entorno da região ruída. } \\
\text { OBS: Nessa região foram encontrados cogumelos } \\
\text { e frutificações de fungos conforme ilustrado na } \\
\text { Figura 6.1. }\end{array}$ & Trichoderma sp. \\
\hline T10E & & $\begin{array}{l}\text { Mapoteca - Amostra retirada próxima à fissura } \\
\text { existente com manchas tênue de bolor. }\end{array}$ & Trichoderma sp. \\
\hline
\end{tabular}

O Trichoderma sp. foi o fungo predominante, sendo identificado na amostra de referência S12BA o Cladosporium sp. e o Penicillium sp..

A Figura 6.16 mostra uma colônia de fungos obtida pelo microcultivo onde predomina o

\section{Trichoderma sp..}

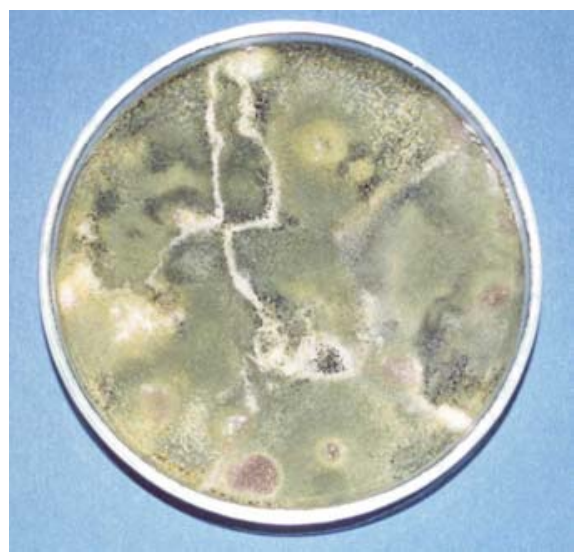

Figura 6. 16 - Colônia de fungos obtida pelo microcultivo, onde predomina o Trichoderma sp. 
A coloração verde da colônia é indicativa do Trichoderma sp., fungo embolorador classificado como fungo mitospórico.

\subsubsection{Observação da superfície da argamassa em microscópio estereoscópico}

A observação da superfície da amostra S19A relativa à interface argamassa-juçara evidenciou estruturas típicas de fungos filamentosos associadas às manchas verdes visíveis na avaliação macroscópica, características do Trichoderma sp. isolado nesta amostra.

Por sua vez, a observação da superfície da amostra T10D, também relativa à interface argamassa-juçara (Figura 6.17), evidenciou impressões deixadas por fungos filamentosos, provavelmente resultantes do descolamento do micélio de fungos apodrecedores. Na Figura 6.2 A, tirada da região do forro onde foi coletada esta amostra, observa-se a presença de cordões miceliais de fungos apodrecedores não identificados. Os cordões miceliais, região central da foto, correspondem às manchas brancas no madeiramento de suporte do assoalho do piso superior (Figura 6.2 a).

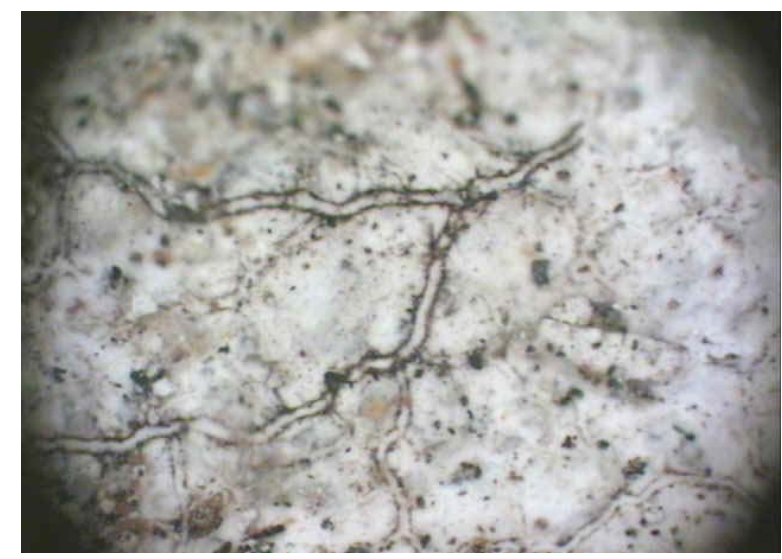

Figura 6. 17-Imagem da amostra T10D em microscópio estereoscópico evidenciando impressões deixadas por fungos filamentosos. 


\subsubsection{Sanidade biológica das ripas de juçara}

O exame microscópico confirmou a presença de esporos e hifas, estruturas típicas de fungos filamentosos, em todas as amostras, inclusive na amostra de referência $\mathrm{S} 19 \mathrm{Cj}$, íntegra. A interpretação conjunta dos exames macro e microscópico das amostras deterioradas indicaram o ataque por fungos apodrecedores, que não foram identificados.

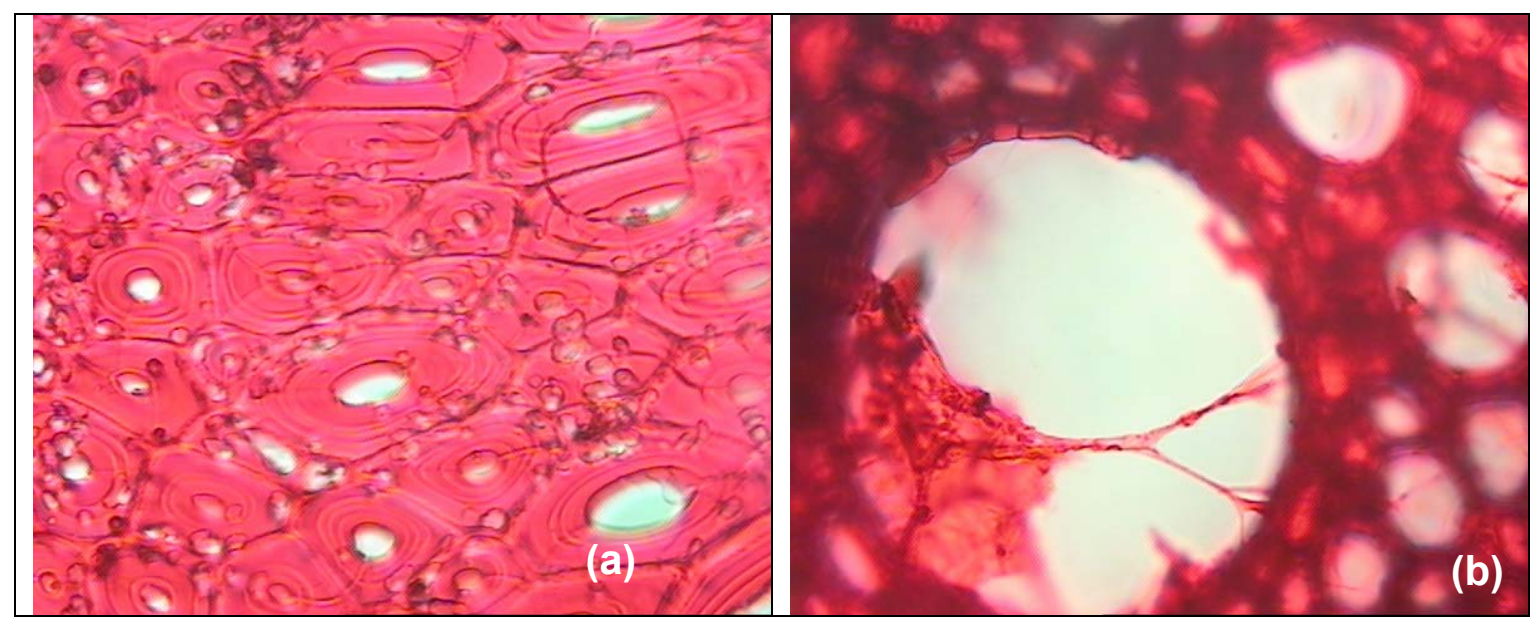

Figura 6. 18 - Imagens em microscópio óptico da lâmina delgada preparada da amostra T10Dj: (a) células intensamente perfuradas por ataque de fungos; (b) detalhe de hifa de fungo no interior de uma célula.

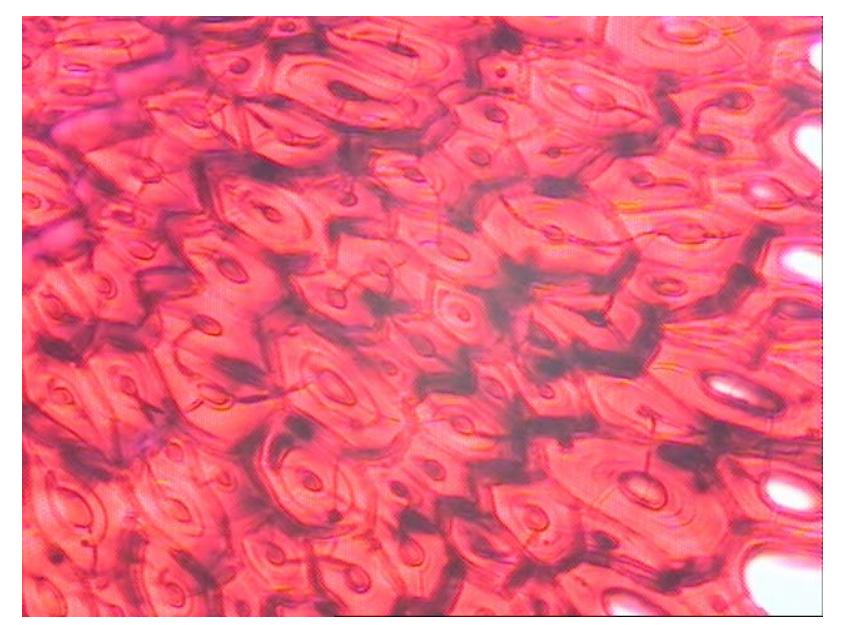

Figura 6. 19 - Imagem em microscópio óptico da lâmina delgada preparada da amostra S19Aj, evidenciando o ataque dos fungos nas células, com hifas rompendo as paredes e se interligando. 


\subsubsection{Considerações sobre a biodeterioração e seu mecanismo}

\section{Quanto aos agentes de biodeterioração:}

Os fungos isolados, apresentados na Tabela 6-4, estão entre os quatro mais freqüentes isolados por SHIRAKAWA (1999), estudo que abrangeu edificações de São Bernardo do Campo e São Paulo com problemas de bolor em revestimento. Conforme pode ser observado na Tabela 6-4, o fungo embolorador predominante é o Trichoderma sp.. A presença de fungos emboloradores dificulta o isolamento de fungos apodrecedores, o que requereria técnicas especiais nestes casos. Portanto, como foi identificado micélio de fungos apodrecedores na amostra T10D, ainda que não identificados pela técnica utilizada, é provável que exista também este tipo de fungo nas amostras de argamassa deterioradas.

A presença de estruturas de fungos na amostra $\mathrm{S} 19 \mathrm{Cj}$, considerada íntegra após a interpretação dos exames macro e microscópico, pode indicar um processo inicial de biodeterioração da juçara, ou uma infestação ocorrida em fases anteriores ao beneficiamento e utilização deste material. Neste último caso, os fungos apodrecedores estariam em fase estacionária de crescimento.

Ainda que não tenha sido investigada a ação de cupins nos forros em estuque, não deve ser descartada a sua ocorrência devido à presença das galerias nas ripas de juçara, conforme ilustrado na Figura 6.2 b, e ter sido mencionada a presença de cupins nos elementos em madeira no Relatório Técnico 161/89 emitido em 1989 pela empresa TECNOMAD Consultoria e Serviço S/C Ltda., documento do arquivo da FAUUSP.

\section{Quanto aos efeitos e mecanismos de biodeterioração:}

A avaliação comparativa das características e da microestrutura das amostras de argamassa aparentemente sãs e deterioradas permite relacionar a diferença do tamanho de vazios com a ação dos agentes de biodeterioração estudados. Os vazios alongados, 
milimétricos a centimétricos, bidimensionais e intercomunicados observados na amostra T10D pela análise petrográfica, podem ter ocorrido devido à atividade biológica dos fungos filamentosos. Estes fungos estariam estendendo o crescimento de suas hifas na superfície da argamassa em contato com a juçara, formando cordões miceliais (rizomorfos), cujas marcas ficaram impressas conforme ilustrado na Figura 6.17. O tipo de crescimento das hifas vegetativas dos fungos apodrecedores, similar ao enraizamento de uma planta, é denominado de crescimento apical.

Considerando esta hipótese assertiva, o mecanismo de biodeterioração ocorrido na argamassa é de natureza física ou mecânica e aparece como conseqüência da deterioração das ripas de juçara.

Não se pode inferir uma hipótese quanto ao mecanismo de biodeterioração por lixiviação da pasta pois, ao contrário do esperado, os teores de pasta nas amostras deterioradas aumentaram, como mostram os resultados da análise petrográfica (Tabela 6-2).

O aumento do teor da pasta nas amostras deterioradas pode ser explicado pela ocorrência da carbonatação no interior da camada de argamassa, o que foi comprovado pelo teor mais elevado de anidrido carbônico $\left(\mathrm{CO}_{2}\right)$ determinado na análise química (Tabela 6-1) e corroborado pela análise petrográfica, através da identificação localizada de cristais micrométricos e birrefringentes de carbonato justapostos, destacando-se do restante da pasta nas amostras S19A e T10D. Corrobora esta hipótese os picos principais de brucita, observados no difratograma da amostra S19X (amostra S19C beneficiada), que não ficaram evidentes nas amostras S19A e T10D, mostrando que o hidróxido de magnésio foi consumido nas amostras deterioradas. 
A carbonatação deve ter sido favorecida pelo aumento dos tamanhos de vazio das amostras deterioradas, vazios milimétricos a centimétricos, identificados pela análise petrográfica.

\subsection{Ensaios de desempenho do sistema de restauro proposto}

\subsubsection{Avaliação visual}

$\mathrm{Na}$ avaliação visual do corpo-de-prova, realizada antes do início dos ciclos, foram observadas fissuras na camada de argamassa nova, paralelas à direção da juçara, possivelmente decorrentes da retração por secagem da argamassa (Figura 6.20).
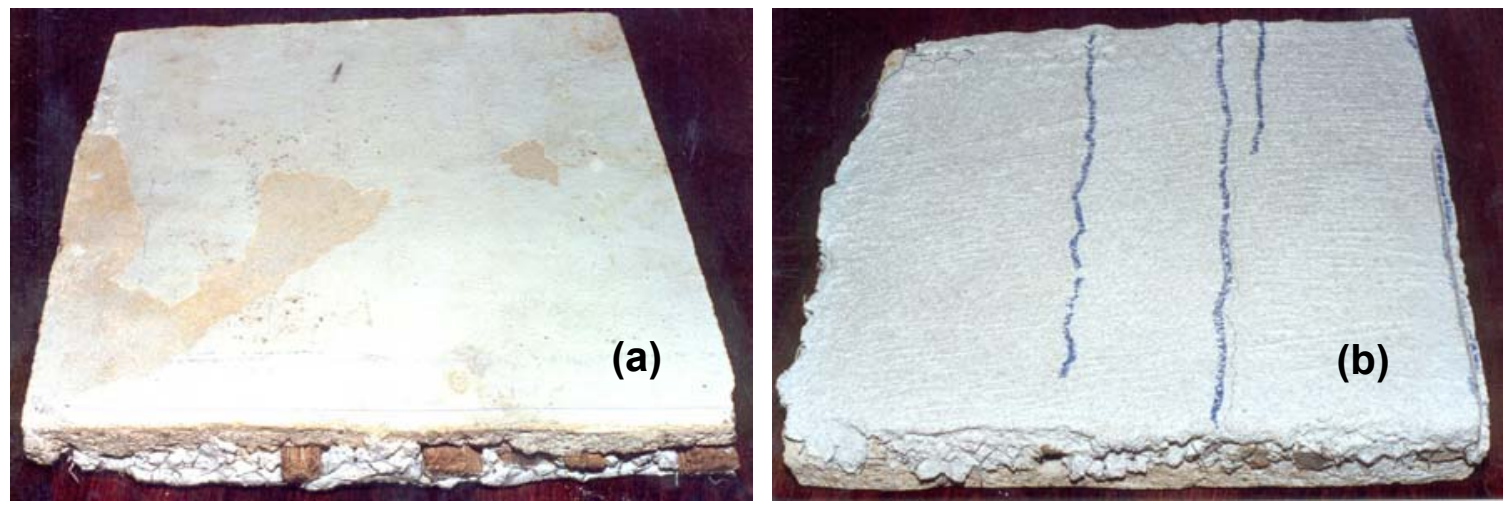

Figura 6. 20 - Corpo-de-prova submetido aos ciclos térmicos após a simulação do sistema de restauro: (a) camada de argamassa do forro original sob as ripas de juçara; (b) camada de argamassa nova sobre as ripas de juçara.

$\mathrm{Na}$ avaliação visual do corpo-de-prova durante os ciclos térmicos e ao final do décimo ciclo, nenhuma alteração foi observada. As fissuras existentes na argamassa nova não avançaram e o corpo-de-prova permaneceu rígido.

\subsubsection{Resistência de aderência do sistema de restauro}

A Tabela 6-5 apresenta os resultados de resistência de aderência do sistema de restauro para as condições ensaiadas. 
Tabela 6 - 5 Resultados de resistência de aderência (MPa)

\begin{tabular}{c|c|c|c|c}
\hline \multirow{2}{*}{ Determinação } & \multicolumn{4}{|c}{ Condições de ensaio } \\
\cline { 2 - 5 } & A & B & C & D \\
\hline $\mathbf{1}$ & 0,77 & 0,05 & 0,53 & 0,00 \\
\hline $\mathbf{2}$ & 0,77 & 0,05 & 0,63 & 0,00 \\
\hline $\mathbf{3}$ & 0,77 & 0,02 & 0,53 & 0,00 \\
\hline $\mathbf{4}$ & 0,79 & 0,02 & 0,60 & 0,00 \\
\hline $\mathbf{5}$ & 0,77 & 0,07 & 0,63 & 0,00 \\
\hline $\mathbf{6}$ & 0,94 & 0,00 & 0,48 & 0,05 \\
\hline Média & 0,80 & 0,04 & 0,57 & 0,01 \\
\hline
\end{tabular}

Condição A: Resistência à tração da argamassa original (resistência potencial).

Condição B: Aderência do sistema de restauro aos materiais originais considerando $50 \%$ de interface argamassa nova/juçara e $50 \%$ argamassa nova/argamassa original (Após 5 ciclos térmicos).

Condição C: Aderência do sistema de restauro à argamassa original, ou seja, $100 \%$ de interface argamassa nova/argamassa original (Após 10 ciclos térmicos).

Condição D: Aderência do sistema de restauro aos materiais original considerando 50 \% de interface argamassa nova/juçara e $50 \%$ argamassa nova/argamassa original (Após 10 ciclos térmicos).

O tipo de ruptura para as condições C e D pode ser observado pela Figura 6.21.

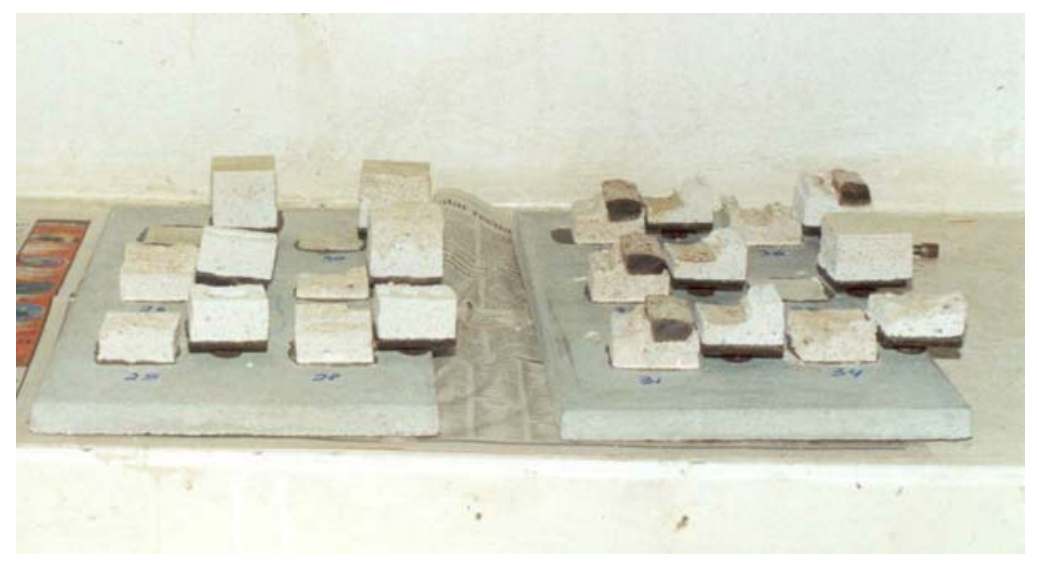

Figura 6. 21 - Tipo de ruptura do ensaio de resistência de aderência. À esquerda: condição $\mathrm{C}$; à direita: condição $\mathrm{D}$.

A Tabela 6-5 mostra que, com a comparação da resistência de aderência entre as condições B e D, observa-se que os ciclos térmicos diminuíram os valores de resistência 
entre o sistema de restauro e os materiais originais. No entanto, a resistência de aderência na condição $\mathrm{C}$ mostra que a remoção das ripas de juçara viabiliza a intervenção do forro adotando uma argamassa simples de cal com as proporções adotadas. O resultado obtido para esta condição é o triplo do especificado pela NBR 13.749 (ABNT, 1996) para revestimento de tetos, que especifica uma resistência de aderência mínima de 0,20 MPa para estes materiais.

A resistência à tração da argamassa original é bastante expressiva, considerando que se trata de uma argamassa simples de cal, quase centenária. Isto permite sugerir que, apesar dos vazios observados pelas análises microestruturais, a argamassa original pode manter sua funcionalidade ao longo dos anos, desde que se opte pela técnica de intervenção correta. Considerando o valor obtido, pode-se inferir também que a fragilidade do sistema de forro em estuque está nas ripas de suporte.

\subsection{Proposta de restauro}

As etapas para restauro do sistema de forro são:

a) escoramento do forro;

b) remoção da camada de argamassa sobre as ripas de juçara;

b) remoção das ripas de juçara;

c) aplicação de solução de cal (água de cal) na argamassa original;

d) intervalo de 60 dias;

e)aplicação da primeira camada de argamassa de cal com aproximadamente $5 \mathrm{~mm}$;

f) posicionamento da tela metálica deploié com arames de amarração;

g) aplicação da segunda camada argamassa de cal (aproximadamente $10 \mathrm{~mm}$ ) e;

h) intervalo de 90 dias antes de recolocação do sistema de piso, no caso do restauro do forro em estuque do pavimento térreo. 


\section{Preparação e aplicação da solução de cal}

Para a preparação da solução de cal adotar cal cálcica CH I, na proporção cal:água, 1:8, em volume.

As etapas da preparação e aplicação da solução de cal são:

a) mistura da água e cal em recipientes plásticos, homogeneizando preferencialmente com misturador de hélice acoplado a furadeira elétrica;

Nota: O volume preparado dependerá da eficiência do equipamento de mistura.

b) deixar a solução em descanso no recipiente plástico por 24 h aproximadamente, para decantação do sólido;

c) coletar a solução sobrenadante por sifonamento, sem misturar com a cal decantada;

d) aplicação da solução de cal na camada de argamassa original a consolidar, vertendo-a lentamente até observação de indícios de umedecimento na superfície da face inferior do forro.

Nota: O serviço deverá ser realizado monitorando-se a face inferior do forro, o que deverá ser considerado ao escolher o sistema de escoramento a ser adotado.

e) Nas regiões consideradas críticas o procedimento deverá ser repetido após 15 dias da primeira aplicação.

\section{Preparação e aplicação da argamassa}

A argamassa de cal deverá ser dosada preferencialmente em massa na proporção $1: 4,7$ (em massa), utilizando uma cal tipo CH III.

O teor de água deverá ser ajustado pelo pedreiro.

A primeira camada de argamassa deverá ser aplicada com aproximadamente $5 \mathrm{~mm}$ de espessura.

Em seguida deverá ser posicionada a tela deploié com arames de amarração posicionados a cada $500 \mathrm{~mm}$. 
Nota: Entre os caibros utilizados anteriormente para fixação das ripas de juçara deverão ser passados barras de aço com $5 \mathrm{~mm}$ de diâmetro a cada $50 \mathrm{~cm}$. Os arames de amarração servirão para fixar a tela metálica a essas barras, atirantando o forro sem exercer tensão no mesmo. A amarração deverá ser realizada somente após a aplicação da segunda camada de argamassa.

A segunda camada de argamassa deverá ser aplicada com aproximadamente $10 \mathrm{~mm}$ de espessura, sendo somente sarrafeada.

A Figura 6.22 ilustra como seria uma seção transversal do forro após a intervenção proposta.

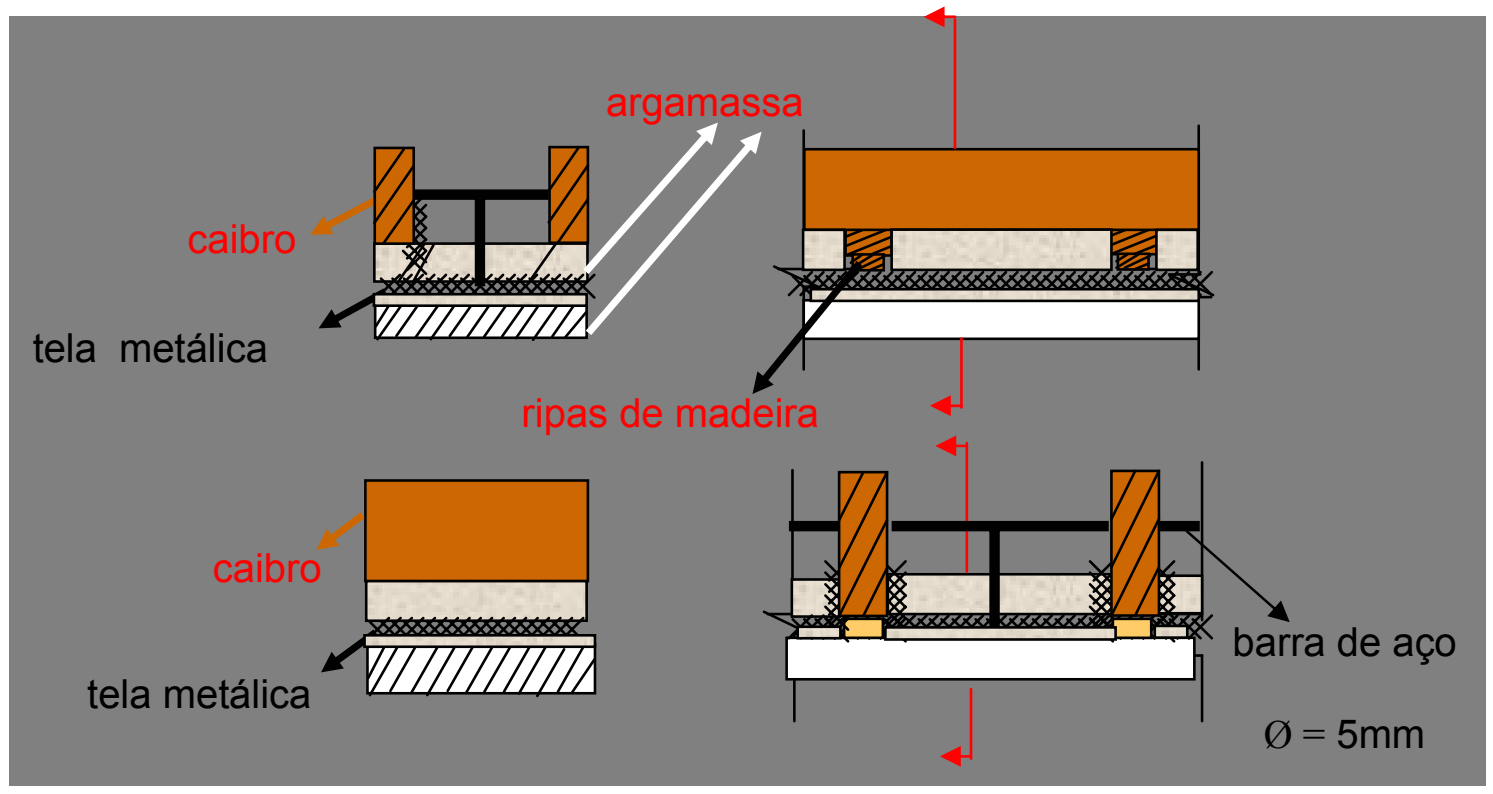

Figura 6. 22 - Seção transversal do forro após intervenção. 


\section{Conclusões}

As principais conclusões deste trabalho são apresentadas a seguir, em resposta aos objetivos propostos.

a) Quanto à coleta e sistematização de dados atualizados sobre as diretrizes que regem as intervenções e o restauro de edificações históricas, tem-se que:

- como principais fontes de diretrizes de restauro tem-se a bibliografia sobre teoria de restauro. Ressalta-se a importância da Carta de Veneza, por ser um dos documentos mais aceitos e difundidos pelo meio técnico, e da BS 7913 “Guide to the principles of the conservation of historic buildings" (BSI, 1998) pelo seu conteúdo e atualidade. Estes dois documentos foram utilizados neste estudo como as principais fontes de consulta.

b) Quanto a coletar e reunir os dados de intervenções ocorridas na edificação Vila Penteado, bem como os dados históricos sobre a sua construção e a sua utilização, ressalta-se que:

- a edificação Vila Penteado passou por dois períodos de abandono, o primeiro após o falecimento da Condessa Ana e o segundo após a transferência do curso de 
graduação de arquitetura e urbanismo para a Cidade Universitária. Esses períodos devem ter contribuído significativamente para o avanço da deterioração do prédio;

- foi verificada a presença de cupins de solo, comuns na região do bairro Higienópolis, em avaliação realizada em 1989. Embora esta avaliação tenha resultado na indicação de medidas corretivas, não se encontraram registros da realização de descupinização, exceto para o madeiramento do telhado, o qual recebeu um tratamento químico. A fonte desta informação não cita a especificação do mesmo;

- a ruptura do forro da mapoteca (cômodo T10) ocorrida em 1994 foi atribuída à deterioração das ripas de juçara, conforme observado e documentado na ocasião;

- as propostas de intervenção anteriores a este estudo não se mostraram adequadas.

c) Quanto a contribuir para o resgate histórico da técnica de revestimento em estuque e das características dos materiais empregados, pode-se dizer que:

- dentre as técnicas construtivas de forro em estuque destaca-se que as referências bibliográficas do século XIX enfocam a composição da argamassa;

- registros sobre o material de suporte são mais comuns nas referências bibliográficas do século XX;

- encontram-se os registros de argamassas para forro em estuque tendo cal e gesso como aglomerantes, e outras com cal como único aglomerante, podendo ser adicionado pó de mármore para obter o aspecto estético desejado; 
- nas referências bibliográficas mais recentes, de meados do século XX, encontra-se o registro de aglomerante cimentício.

- Quanto ao tipo de suporte do estuque, conforme LONDON (1992) a utilização de telas metálicas ocorreram somente a partir de $1920^{7.1}$.

d) Quanto ao levantamento das principais técnicas de investigação aplicadas a revestimentos de argamassa de edificações históricas, ressalta-se que:

- relaciona-se como principais técnicas a serem utilizadas em estudo de argamassas antigas a difração por raios $\mathrm{X}$, a análise química, a análise granulométrica e a análise petrográfica;

- a análise granulométrica necessita uma quantidade de material significativamente superior ao necessário para as demais análises, o que pode ser um empecilho para a sua realização, podendo em alguns casos adotar-se a faixa granulométrica predominante indicada pela análise petrográfica como referência para a recomposição da argamassa.

e) Quanto a fornecer subsídio para a restauração do forro em estuque reforçado com ripas de juçara, com base no estudo dos materiais, da técnica original e da biodeterioração por fungos, conclui-se que:

\footnotetext{
${ }^{7.1} \mathrm{O}$ sistema construtivo do forro em estuque em toda a edificação deve ser anterior a este período, ou seja,
} até mesmo na região localizada onde não existe a camada superior de argamassa que pode estar relacionado a uma intervenção posterior à construção, o forro apresenta idade superior a 80 anos. 
- o forro em estuque da Edificação Vila Penteado caracteriza-se por ter como suporte ripas de juçara justapostas, envolvidas por camadas de argamassa simples de cal e areia quartzosa, na proporção 1:6 (aglomerante : agregado). Esta proporção considera a utilização de cal virgem como de costume na época da construção da edificação. A granulometria predominante da argamassa sobre as ripas de juçara, com função de proteção mecânica das ripas, está entre 1,80 e 3,00 mm. Na

argamassa sob as ripas de juçara, com função de acabamento e suporte de pinturas murais, está entre 0,46 e 0,90 mm;

- a biodeterioração foi considerada como o fator determinante para a falência parcial do forro, reusltando no desabamento de parte do forro na mapoteca (cômodo T10) no ano de 1994. Foram observados fungos apodrecedores no madeiramento e nas ripas de juçara, bem como fungos emboloradores na argamassa;

- foi evidenciado que a fragilidade do sistema de forro em estuque está nas ripas de suporte, devido à resistência à tração da argamassa original ter sido aproximadamente $0,6 \mathrm{MPa}$, valor que é praticamente o triplo do especificado pela NBR 13749 (ABNT, 1996) para revestimentos de tetos. Porém, evidências de deterioração também são vistas na argamassa, indicando que a ação dos fungos gerou alterações físicas e mecânicas neste material, aumentando a sua porosidade;

- o estudo resultou numa proposta de restauro, que prevê a substituição das ripas de juçara por tela metálica, devido à fragilidade e à baixa aderência das ripas à argamassa de reparo, mesmo que esta possua composição semelhante à original. 
Anexos 


\section{ANEXO A - BREVE LEVANTAMENTO CADASTRAL DA EDIFICAÇÃO VILA PENTEADO}

A edificação Vila Penteado foi objeto de estudo em outras pesquisas, que sempre contaram com o apoio da direção da FAUUSP. A principal delas foi coordenada pela pesquisadora Maria Cecília Nacléreo Homem Prado, visando o tombamento da edificação e resultou na publicação do livro "Exposição Vila Penteado", onde encontram-se reunidas informações sobre a história da edificação, seus usuários e seu entorno. O levantamento histórico da edificação, apresentado a seguir, está baseado nesta publicação, bem como nos Boletins Técnicos publicados pela FAU em 1993, durante a gestão da professora Gilda Collet Bruna, e em documentos cedidos pelo Professor Júlio Roberto Katinsky, durante sua gestão como Diretor da FAU.

\section{A.1 Breve Histórico da Evolução Urbana e Arquitetônica da Cidade de São Paulo}

Neste item serão ressaltados os fatos que influenciaram direta ou indiretamente a arquitetura da cidade de São Paulo, enfatizando principalmente aqueles que atuaram sobre o bairro Higienópolis, no qual está inserida a edificação Vila Penteado. 
A arquitetura dos três séculos que antecederam a grande mudança econômica da cidade de São Paulo pouco variou durante esse período. Esta arquitetura se caracterizava por casas baixas com telhados de duas águas.

Somente no final do século XIX os traços da colonização portuguesa, presentes nas fachadas da cidade, começaram a ser substituídos pela arquitetura francesa, do gosto dos fazendeiros do café e, posteriormente, com a chegada dos imigrantes, as características da arquitetura italiana também foram tomando seu espaço.

A partir de 1870, concomitantemente com a migração da elite latifundiária para São Paulo, que visava expandir o comércio e a exportação da produção de café, as construções passaram a utilizar um novo sistema de vedação, introduzido na região pelos imigrantes. A taipa de pilão, muito característica da sociedade bandeirante, passou a ser substituída por alvenaria de tijolos. O Monumento do Ipiranga (1890), a Escola Normal Caetano de Campos (1895) e o antigo prédio da Escola Politécnica (1900), hoje FATEC, são exemplares da utilização do novo sistema construtivo. A Figura A.1 mostra uma vista geral da cidade de São Paulo no ano de 1895.

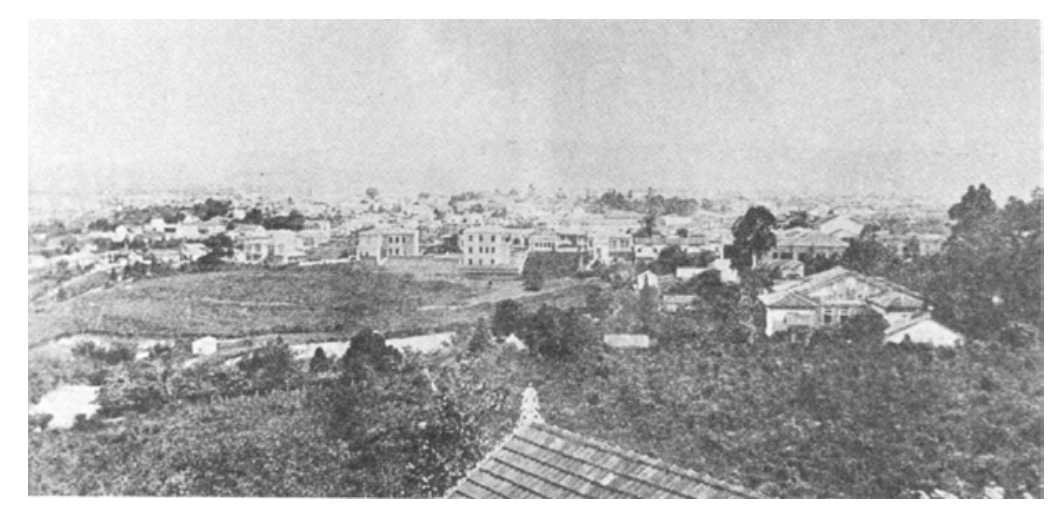

Figura A.1 - Vista de São Paulo em 1895 (UNIVERSIDADE DE SÃO PAULO, 1976). 
Em decorrência do desenvolvimento urbano no início do século XX, surgiram as inovações na infra-estrutura e no transporte, tais como o fornecimento de água, a coleta de esgoto, a introdução da iluminação elétrica e a substituição dos bondes puxados a burro, que ligavam o centro da cidade à Avenida Paulista e a outros bairros isolados, pelos primeiros bondes elétricos. Como marco dessas mudanças, tem-se em 1901 a instalação da primeira geradora hidroelétrica pela São Paulo Traction Light and Power Company, iniciativa esta que impulsionou a indústria fabril.

Com a expansão da cidade, a zona residencial transferiu-se para as regiões mais elevadas e o centro passou a reunir as atividades comerciais, de prestação de serviços e algumas fábricas. Os bairros Higienópolis e Cerqueira César passaram a abrigar as residências dos principais cafeicultores e burgueses. Entre estes, famílias tradicionais como a Álvares Penteado.

A distribuição urbana, cuidadosamente projetada, baseada nos boulevards franceses, tornou-se característica marcante dos bairros nobres, entre eles o Higienópolis. O recuo das casas e os seus jardins introduzidos na época simbolizavam o isolamento das famílias nobres do cotidiano da cidade e do convívio com o proletariado.

Higienópolis, até então sob denominação de Boulevards Buchard, foi estruturado ao longo de dois eixos, a avenida Higienópolis e a avenida Angélica, naquela época denominada de avenida Itatiaia. Considerado bastante inovador devido à sua riqueza arquitetônica e paisagística, o bairro serviu de modelo para novos loteamentos.

Os primeiros bairros operários, assim como o Brás e aqueles situados da Barra Funda até o Belenzinho, formaram-se próximo às fábricas. 


\section{A.2 Histórico de Ocupação da Edificação}

$\mathrm{O}$ terreno do palacete estava inserido num loteamento residencial da empresa Victor Nothman e Martinho Burchard, cuidadosamente projetado e implantado para o usufruto da elite (MACEDO, 1993). O terreno era limitado pela atual Av. Higienópolis e pelas ruas Itambé, Maranhão e Sabará.

A edificação Vila Penteado foi projetada pelo arquiteto sueco Carlos Ekman, que imigrou para o Brasil em 1898. O projeto em estilo Art Nouveau teve influência de obras precedentes assinadas por Lallerstedt e Broberg, com os quais Carlos Ekman conviveu anteriormente em Estocolmo (REITER, 1993).

Segundo consta no livro UNIVERSIDADE DE SÃO PAULO (1976), no dia 04 de março de 1902, o projetista deu entrada no pedido de aprovação do projeto na Prefeitura. O projeto incluía a edificação principal, área de lazer (jardins e quadra de tênis) e inúmeros outros prédios isolados entre si e dispersos entre os jardins (pavilhão, cocheiras e alojamento de empregados). O palacete serviria de residência das famílias do Conde Antonio Álvares Penteado na ala maior, e de seu genro, Antonio Prado Junior, na ala menor. A inauguração da obra data de 1903, porém a ala menor só foi construída na reforma realizada em 1909 (Figura A.2). O requinte preponderante na parte da edificação destinada à família do Conde Penteado foi expresso nas pinturas murais. Como exemplos têm-se o corredor lateral de acesso ao saguão (pavimento térreo), que se caracteriza por ser um ambiente de orientação Sessezion (Figura A.3) e o forro das dependências íntimas do 
Conde (pavimento superior), que apresenta uma pintura tecnicamente mais complexa que a maioria dos outros cômodos, tendo sido os desenhos feitos com máscaras compostas, possibilitando a sobreposição de cores.

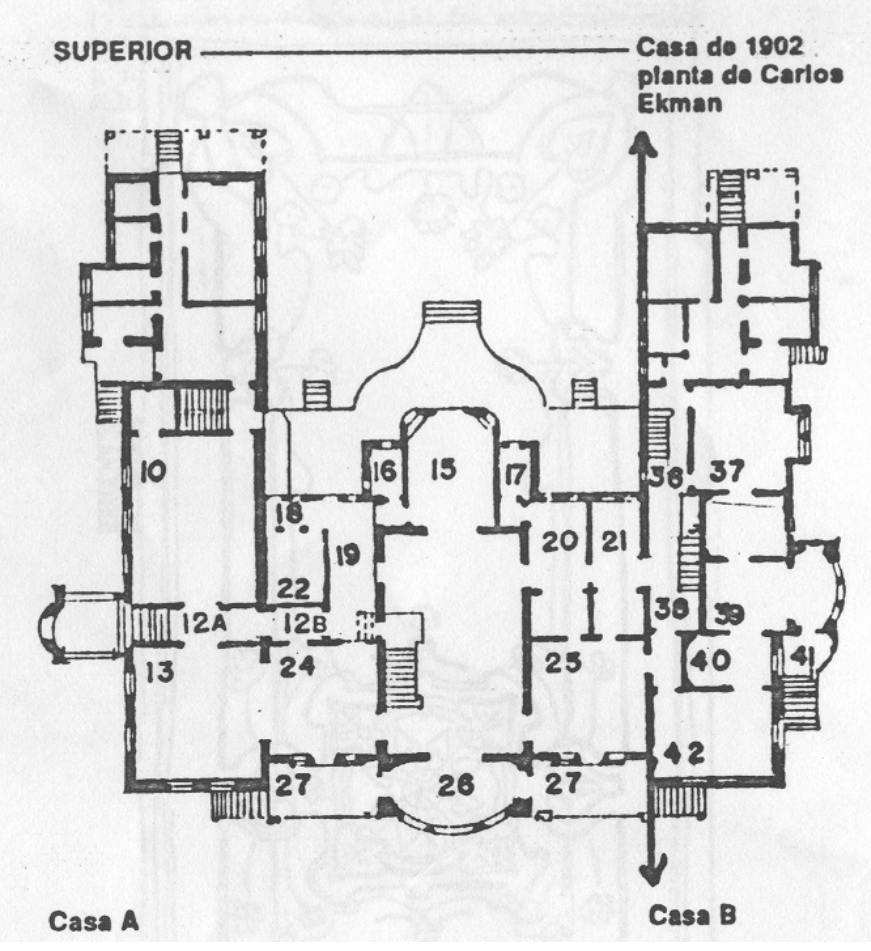

Figura A. 2 - Edificação Vila Penteado - residência bi-familiar. 


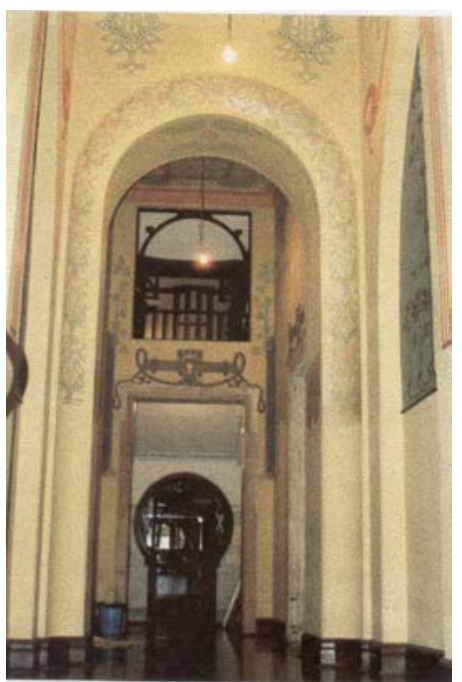

Figura A. 3 - Corredor lateral de acesso ao hall principal que se caracteriza por ser um ambiente de orientação Sessezion.

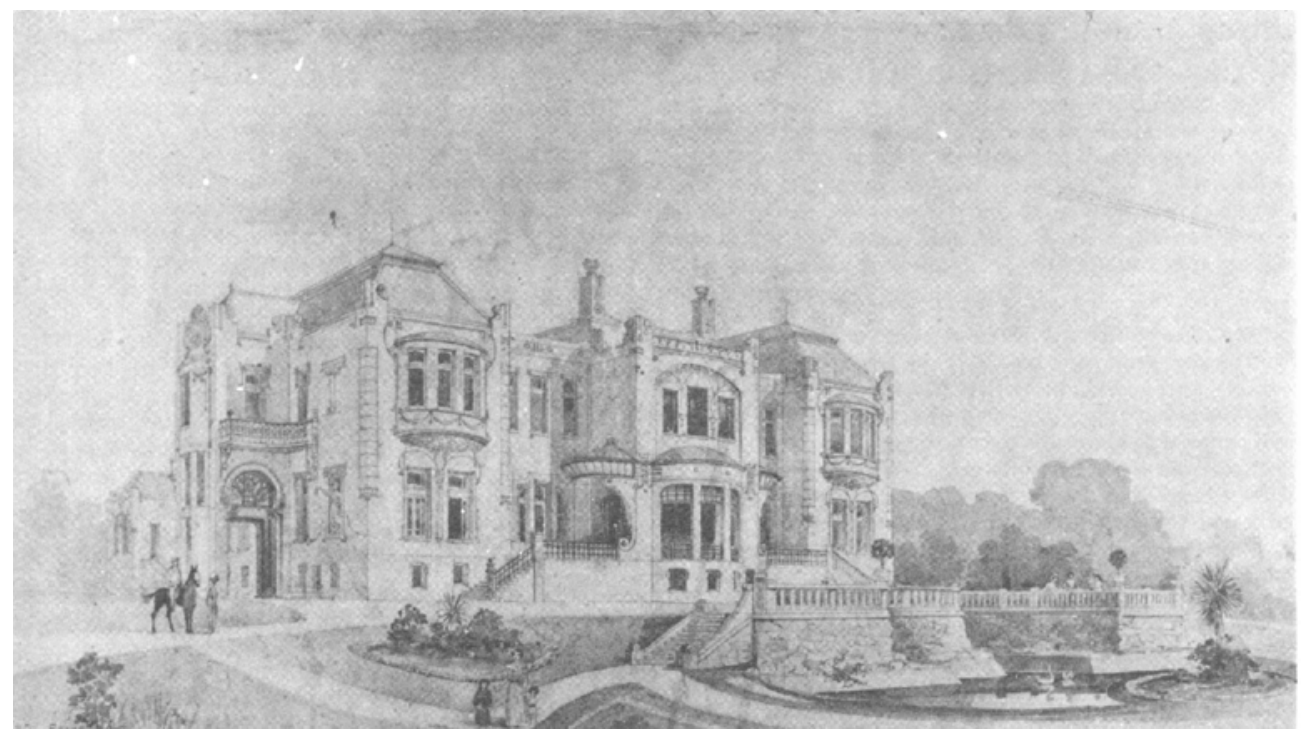

(a) 

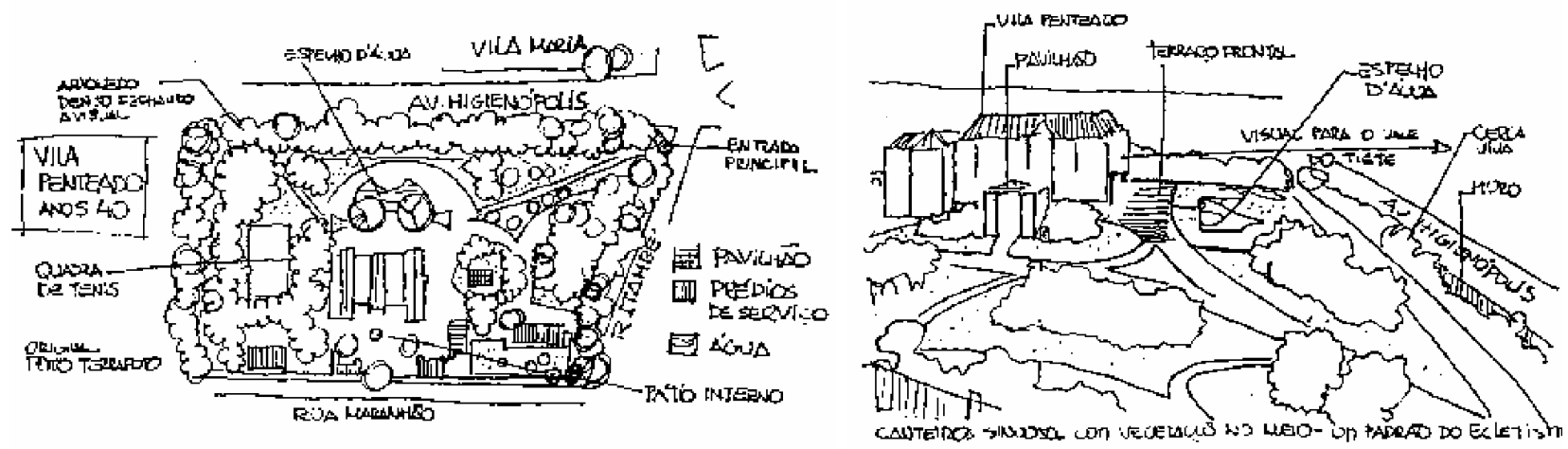

(b)

Figura A.4 - (a) Aquarela original datada de 1902 (UNIVERSIDADE DE SÃO PAULO, 1976); (b) Representação esquemática da disposição do conjunto de prédios do projeto da Vila Penteado (MACEDO, 1993 Vila Penteado - A Vila Penteado, Significado Paisagístico).

Após o falecimento da Condessa Ana Álvares Penteado, em 1938 então viúva, o casarão permaneceu fechado por quase 10 anos, quando seus filhos Silvio Álvares Penteado e Armando Álvares Penteado doaram-no à Universidade de São Paulo para sediar a Faculdade de Arquitetura e Urbanismo, loteando o restante do terreno. Desde então, a fachada principal voltada para a Av. Higienopólis passou a ser os fundos da edificação e esta teve como novo endereço a Rua Maranhão $n^{\circ} 88$.

A Faculdade de Arquitetura e Urbanismo começou a funcionar nessas instalações a partir de 1948, contando com aproximadamente 50 alunos. A ocupação do prédio foi 
comemorada com uma exposição em homenagem ao primeiro aniversário do GFAU ${ }^{\mathrm{A} .1}$, em 5 de novembro de 1949, e a Mário de Andrade, na $2^{\mathrm{a}}$ Semana Nacional de Folclore.

Em 1966 o curso de graduação foi transferido para a Cidade Universitária e a partir de então a Vila Penteado passou por nova fase de abandono e descuido. No palacete permaneceu somente o Centro de Pesquisa e Estudos Urbanísticos.

No ano de 1973 foi dado início a um novo período na história da edificação, que passou a acolher os seguintes grupos de estudo e pesquisa: planejamento urbano e regional; planejamento habitacional; racionalização da construção; planejamento de transportes; planejamento paisagístico e ambiental; semiótica do ambiente urbano; restauração e conservação de monumentos e conjuntos históricos e métodos; todos com ênfase na informação científica. Marcando este novo período no qual a edificação passou a abrigar os cursos de especialização e pós-graduação da FAU, foi realizado com grande mérito o Curso de Restauração e Conservação de Monumentos e Conjuntos Históricos em agosto de 1974, ministrado pelos professores Hugues de Varine-Bohan da França; Viana de Lima de Portugal e Vitor Pimentel ${ }^{\mathrm{A} .2}$ do Peru.

Após um minucioso trabalho de resgate histórico da edificação realizado por membros do CAEC/FAU ${ }^{\text {A.3 }}$, a edificação Vila Penteado foi tombada em 1978 pelo CONDEPHAAT -

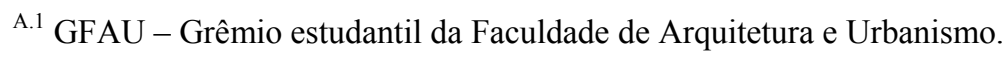

A.2 Vitor Pimentel participou da elaboração da Carta de Veneza de 1964.

${ }^{\text {A.3 }}$ CAEC/FAU - Comissão de Atividades Extra-curriculares da FAU.
} 
Conselho de Defesa do Patrimônio Histórico, Arquitetônico e Artístico do Estado de São Paulo e em 1991 pelo CONPRESP - Conselho de Patrimônio da Cidade de São Paulo.

Na década de 90, apesar da realização de alguns serviços de manutenção com a escassa verba da Universidade destinada para este fim, o envelhecimento natural da edificação, bem como os danos irreversíveis durante os períodos de abandono, resultaram no colapso parcial do forro em estuque desencadeando a interdição do prédio. No dia 08 de julho de 1994, após a fatídica interdição, o professor Gustavo Neves da Rocha Filho, membro da Conselho Curador da FAU, publicou no Jornal da Tarde uma carta procurando chamar a atenção dos leitores sobre a necessidade de preservar este exemplar do patrimônio da sociedade paulistana e apresentando sua sugestão de como proceder. Algumas intervenções emergenciais foram realizadas, possibilitando a liberação da edificação. No entanto, a investigação aprofundada e o saneamento do problema não foram alcançados, despertando o interesse pela realização desta pesquisa.

\section{A.3 Levantamento Técnico da Edificação}

\section{A.3.1 Distribuição e utilização da edificação}

A edificação de aproximadamente $1.500 \mathrm{~m}^{2}$, possui dois pavimentos com disposição em "U" e um subsolo, conforme apresentado na Figura A.5. Durante a vistoria na fase preliminar deste estudo foram identificadas modificações na distribuição dos cômodos, os quais totalizavam 22 no pavimento térreo e 27 no pavimento superior. Essas modificações podem ser verificadas ao se comparar a distribuição atual com aquela apresentada nas plantas do projeto original. As utilizações a que estavam destinados estes cômodos foram 
relacionadas nas Tabelas A-2 e A-3. No subsolo encontram-se as instalações da coordenação do canteiro-escola do Programa de Formação de Restauradores em Pinturas Murais, criado pela Comissão do Patrimônio Cultural da USP e de uma loja de fotocópias; além de depósitos de materiais e do reservatório de água.

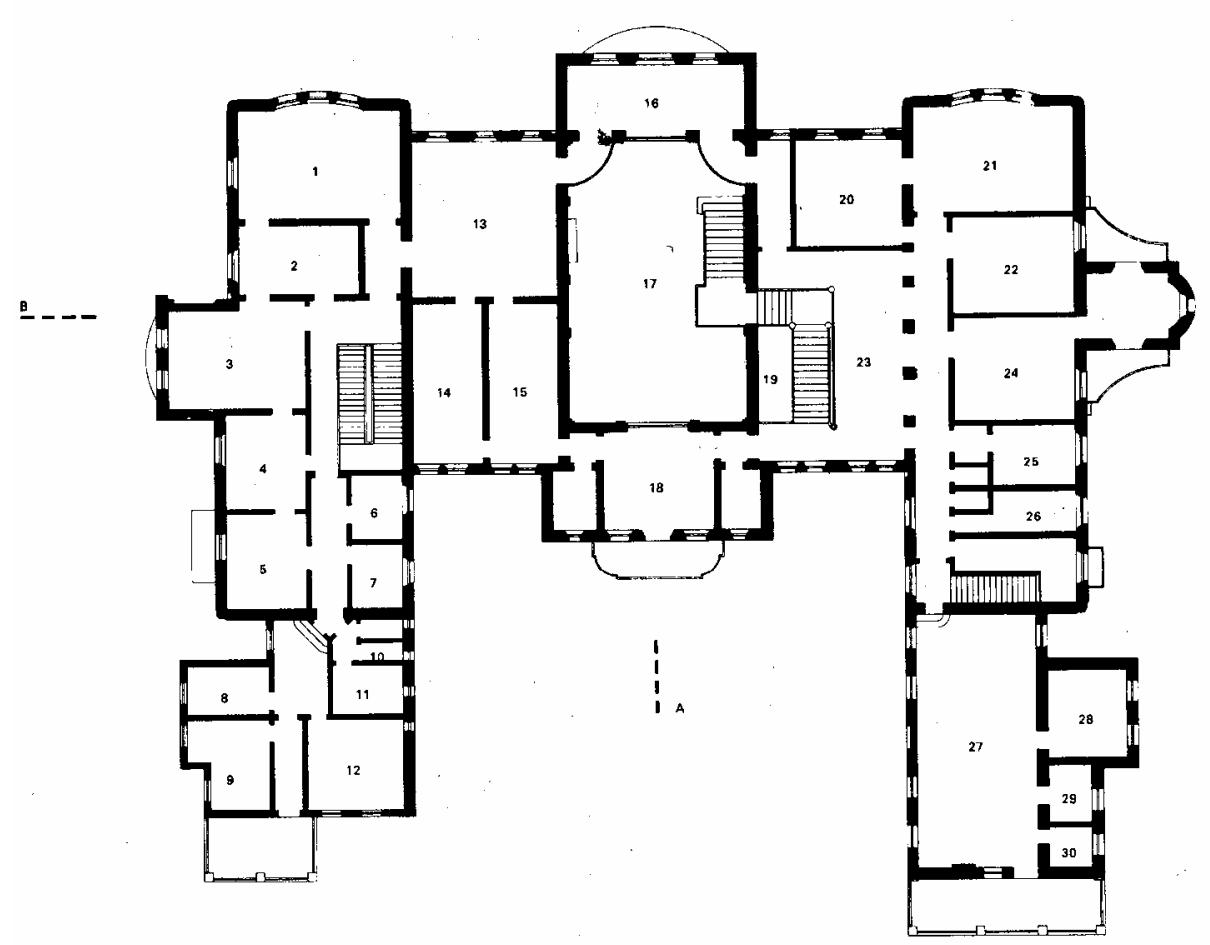

(a) 

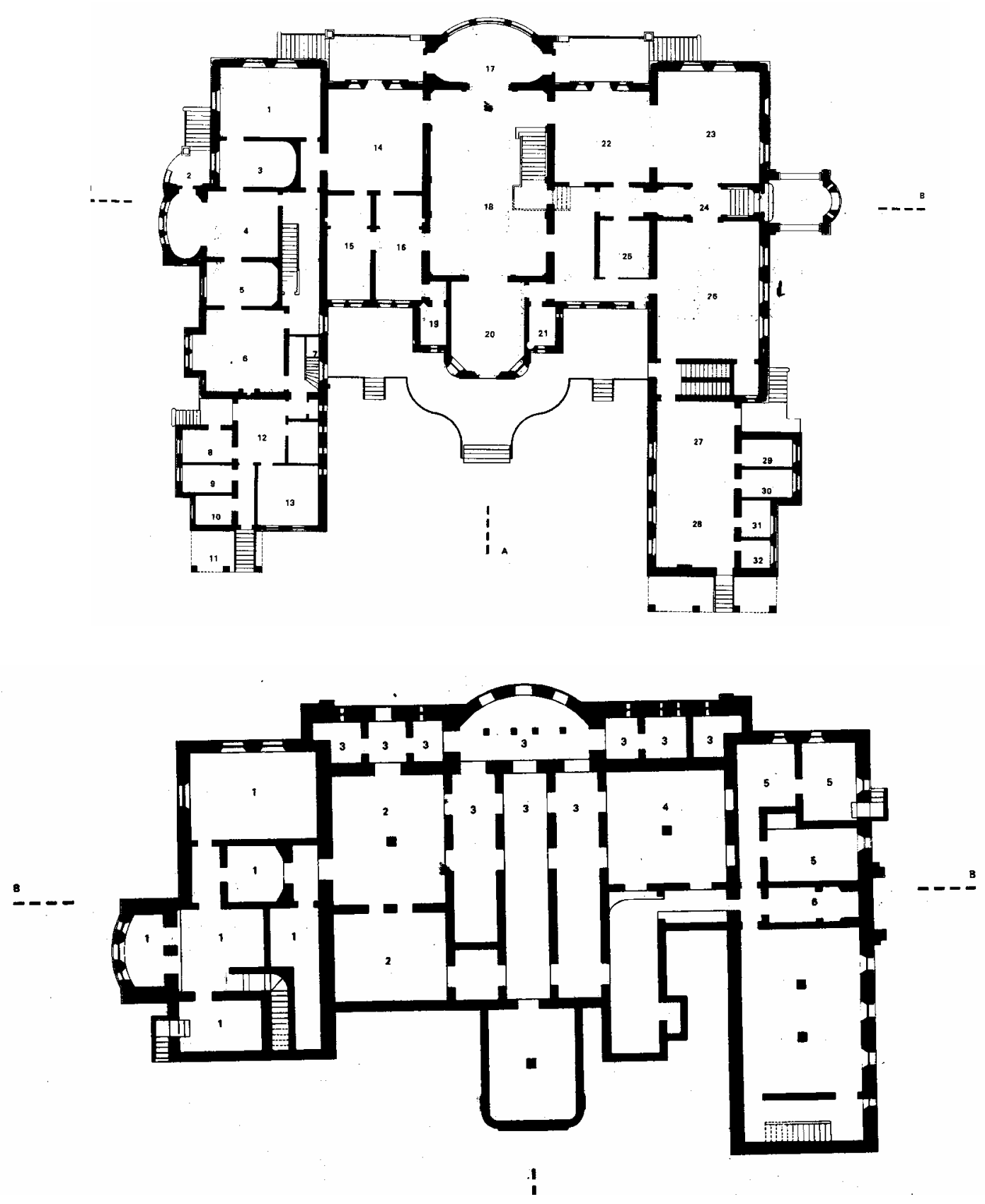

(c)

Figura A. 5 - Planta baixa original do pavimento térreo (a); Planta baixa original do pavimento superior (b); Planta baixa original do subsolo (c). 
A edificação possui paredes estruturais construídas em alvenaria de tijolos cerâmicos, revestidas externa e internamente com argamassa. No interior encontram-se pinturas murais decorativas que vêm sendo resgatadas, enquanto na fachada a pintura é lisa, apresentando atualmente uma única tonalidade.

A estrutura de sustentação do telhado e do piso é constituída de sistemas convencionais em madeira. Para a estrutura original de sustentação do telhado foram empregadas Peroba Rosa e Pinho de Riga. Este último tipo de madeira foi considerado exótico pelos técnicos responsáveis pela identificação, provavelmente por não ser empregado para este fim com freqüência. Por sua vez, na estrutura original do piso foram empregadas Peroba Rosa, Cabriúva Parda, Guatambú, e Pinho do Paraná (RELATÓRIO TECNOMAD-161/89).

A madeira também foi empregada nos caixilhos e venezianas ${ }^{\text {A.4 }}$, além de alguns forros. Os tipos de madeira empregados na edificação identificados pela TECNOMAD estão apresentados na Tabela A-1. A.5

\footnotetext{
A.4 A madeira empregada nas venezianas é o Pinho de Riga como se verificou durante uma das visitas à edificação após a decapagem da pintura nesses elementos (2001), porém em 1991 foi proposta a utilização de mogno para a intervenção nesses elementos.

A.5 A identificação dos elementos considerados não estruturais e decorativos baseou-se em um pequeno número de amostras. Tendo sido esta identificação generalizada de acordo com a semelhança do aspecto visual.
} 
Tabela A- 1 Tipos de madeira empregados nos elementos construtivos da edificação Vila Penteado (RELATÓRIO TECNOMAD-161/89)

\begin{tabular}{|c|c|c|c|}
\hline \multirow[t]{2}{*}{ Elementos Construtivos } & \multicolumn{3}{|c|}{ Tipos de Madeira } \\
\hline & \multicolumn{2}{|r|}{ Nomenclatura Comercial } & Nomenclatura Científica \\
\hline \multicolumn{4}{|l|}{ Estrutura do Telhado } \\
\hline \multirow[t]{2}{*}{ Tesouras e terças } & \multicolumn{2}{|c|}{ Peroba Rosa } & Aspidosperma polyneuron \\
\hline & \multicolumn{2}{|c|}{ Pinho de Riga } & \\
\hline Caibros e ripas & \multicolumn{2}{|c|}{ Peroba Rosa } & Aspidosperma polyneuron \\
\hline Barroteamento do forro & \multicolumn{2}{|c|}{ Peroba Rosa } & Aspidosperma polyneuron \\
\hline \multirow[t]{3}{*}{ Forro de madeira } & \multicolumn{2}{|c|}{ Pinho do Paraná } & Araucária angustifolia \\
\hline & \multicolumn{2}{|c|}{ Pinho de Riga } & \\
\hline & \multicolumn{2}{|c|}{ Peroba Rosa } & Aspidosperma polyneuron \\
\hline Ripas do estuque de forro & \multicolumn{2}{|c|}{ Palmeira } & Família Palmae \\
\hline \multicolumn{4}{|l|}{ Estrutura de Piso } \\
\hline Barroteamento de piso & \multicolumn{2}{|c|}{ Peroba Rosa } & Aspidosperma polyneuron \\
\hline \multirow[t]{3}{*}{ Assoalho } & \multicolumn{2}{|c|}{ Cabriúva parda } & Myrocarpus spp. \\
\hline & \multicolumn{2}{|c|}{ Guatambú } & Aspidosperma spp. \\
\hline & \multicolumn{2}{|c|}{ Peroba Rosa } & Aspidosperma polyneuron \\
\hline $\begin{array}{l}\text { Barroteamento do forro do } \\
\text { porão }\end{array}$ & \multicolumn{2}{|c|}{ Pinho do Paraná } & Araucária angustifolia \\
\hline \multicolumn{4}{|l|}{ Elementos não estruturais } \\
\hline \multicolumn{2}{|l|}{$\begin{array}{l}\text { Escada }- \text { estrutura portante, } \\
\text { degãos, corrimão, lambril, } \\
\text { guarda-corpos } \\
\text { (saguão/ala direita/ala esquerda) }\end{array}$} & Cabriúva vermelha & Myroxylon spp. \\
\hline Lambril & & Pinho de Riga & \\
\hline
\end{tabular}

Nas áreas úmidas (banheiros e cozinha de funcionários), o piso encontrava-se revestido em alguns casos com placas cerâmicas hidráulicas e em outros com revestimento vinílico.

b) Cobertura 
O sistema de cobertura utiliza telha de ardósias, seguindo tendência européia da época de construção da edificação, com complementos (rufos, espigões, rincões, calhas e grampos de fixação das telhas) em cobre.

Internamente a estrutura de sustentação do telhado é revestida por forro em madeira ou em estuque. (Tabelas A-2 e A-3)

Tabela A-2 -Utilizações dos cômodos e tipos de forros do pavimento térreo

\begin{tabular}{|c|c|c|c|}
\hline $\begin{array}{l}\text { Identificação } \\
\text { do cômodo }\end{array}$ & $\begin{array}{c}\text { Identificação } \\
\text { FAU }\end{array}$ & Tipo de ocupação & Tipo de forro \\
\hline T01 & 30 & Biblioteca & Madeira \\
\hline T02 & 31 & Não acessado & Não acessado \\
\hline T03 & 29 & Cozinha dos funcionários & Estuque \\
\hline T04 & 33 & Biblioteca & Estuque \\
\hline T05 & 32 & Sanitário dos funcionários & Madeira \\
\hline T06 & 37 & Biblioteca & Estuque/Madeira \\
\hline T07 & 29 & Biblioteca & Estuque \\
\hline T08 & 40 & Biblioteca & Estuque \\
\hline T09 & 42 & Biblioteca & Estuque \\
\hline T10 & 25 & $\begin{array}{l}\text { Biblioteca - Mapoteca (local } \\
\text { onde ocorreu o colapso parcial } \\
\text { do forro em 1994) }\end{array}$ & Estuque \\
\hline T11 & 21 & Sala de discussão de alunos & Estuque \\
\hline T12 & 20 & Sala de discussão de alunos & Estuque \\
\hline T13 & 23 & Hall principal & Madeira \\
\hline T14 & 15 & Portaria & Madeira \\
\hline T15 & 13 e 24 & Auditório & Estuque \\
\hline T16 & 18 & Sanitário dos funcionários & Placa de gesso \\
\hline $\mathrm{T} 17$ & 10 & Sala de aula & Madeira \\
\hline $\mathrm{T} 18$ & 4 & Sala de aula & Estuque \\
\hline T19 & 6 & Não acessado & Não acessado \\
\hline $\mathrm{T} 20$ & 5 & Depósito & Madeira \\
\hline $\mathrm{T} 21$ & 3 & Depósito & Madeira \\
\hline $\mathrm{T} 22$ & 2 & Depósito & Madeira \\
\hline
\end{tabular}


Tabela A-3 Utilizações dos cômodos e tipos de forros do pavimento superior

\begin{tabular}{|c|c|c|c|}
\hline $\begin{array}{l}\text { Identificação } \\
\text { do cômodo }\end{array}$ & $\begin{array}{c}\text { Identificação } \\
\text { FAU }\end{array}$ & Tipo de ocupação & Tipo de forro \\
\hline S01 & 70 & Sala de docente & Madeira \\
\hline S02 & 69 & Sala de docente & Madeira \\
\hline S03 & 72 & $\begin{array}{lll}\begin{array}{l}\text { Ante-sala } \\
\text { anteriores }\end{array} & \text { dos cômodos } \\
\end{array}$ & Madeira \\
\hline S04 & 71 & Sanitário & Madeira \\
\hline S05 & 75 & Sala de docente & Madeira \\
\hline S06 & 73 & Sanitário & Madeira \\
\hline S07 & 78 & Sala de docente & Estuque \\
\hline S08 & 76 e 77 & Não acessado & Não acessado \\
\hline S09 & 79 & Sala de docente & Estuque \\
\hline S10 & 81 & Sala de aula & Estuque \\
\hline S11 & 66 & Sala de aula & Estuque \\
\hline S12 & 62 & Sala do diretor & Estuque \\
\hline S13 & 58 & Sanitário & Madeira \\
\hline S14 & 59 & Balcão & Estuque \\
\hline S15 & 57 & Não acessado & Não acessado \\
\hline S16 & 67 & Balcão & Estuque \\
\hline S17 & 64 & Sala de docente & Estuque \\
\hline $\mathrm{S} 18$ & 55 & Sala de reuniões & Estuque \\
\hline S19 & 60 & Hall Superior & Estuque \\
\hline S20 & 54 & Secretaria & Estuque \\
\hline S21 & 53 & Secretaria & Estuque \\
\hline S22 & 51 & Sanitário & Madeira/Estuque \\
\hline $\mathrm{S} 23$ & 49 & Não acessado & Não acessado \\
\hline S24 & 46 & Laboratório de computação & Madeira \\
\hline $\mathrm{S} 25$ & 47 & Laboratório de computação & Madeira \\
\hline S26 & 45 & Laboratório de computação & Madeira \\
\hline S27 & 44 & Laboratório de computação & Madeira \\
\hline
\end{tabular}

Segundo a vistoria realizada por membros da CPC da USP em 1994, os forros de madeira da época da construção possuem tábuas de aproximadamente $14 \mathrm{~cm}$ de largura, enquanto as da reforma de 1909 apenas $9 \mathrm{~cm}$. Ambas apresentam pintura monocromática com tonalidades claras (branco, areia e creme). 


\section{A.3.2 Registro cronológico de vistorias, recomendações de recuperação e intervenções na edificação}

A seguir estão relacionadas as informações referentes aos serviços de manutenção, conservação e preservação da edificação Vila Penteado, organizadas em ordem cronológica. No entanto, pode haver alguma defasagem entre o fato descrito e o ano mencionado, uma vez que a maioria dessas informações foi resgatada a partir de documentos não necessariamente datados. Ressalta-se ainda que não se conseguiu comprovar se todas as propostas de recuperação e os serviços especificados foram executados.

1980 - após ter sido realizado um levantamento e diagnosticado as falhas do processo construtivo, no qual foi identificado o comprometimento das funções das esquadrias, da argamassa de revestimento de fachada e da cobertura, foram especificados os seguintes materiais e serviços (SIMÕES, 1993):

- reparo ou substituição de esquadrias e venezianas, utilizando elementos com dimensões e detalhes iguais aos originais em mogno;

- dobradiças em "ferro batido comum" e parafusos de latão;

- chapisco com traço $1: 3$ (cimento e areia, em volume);

- reboco com argamassa mista com traço $1: 1,33: 6,66$ (cimento, cal e areia, em volume);

- substituição das telhas de ardósia quebradas e dos ganchos de latão similares aos originais e;

- recuperação de calhas e condutores danificados. 
Nesta ocasião, foram colocadas novas esquadrias no pavimento superior, recuperadas as esquadrias existentes no térreo e recuperadas parcialmente a cobertura e a argamassa de fachada (ROCHA FILHO, 1994).

1985 - Contratação da empresa COTTA LTDA. ${ }^{\text {A.6 }}$ para dois serviços:

- colocação de novas persianas em vãos dos quais haviam sido removidas pelas administrações anteriores e;

- recuperação das esquadrias e de parte do revestimento de argamassa que não haviam sido contemplados na intervenção anterior e da pintura da fachada.7, segundo recomendações de técnicos do IPHAN e do IPT.

Para este último serviço foi especificado (SIMÕES, 1993):

- lavagem da pintura com jato de água;

- pintura das paredes com caiação, de modo a obter cor e textura original obtida por prospecção feita por técnicos do IPT ${ }^{\mathrm{A} .8}$;

- pintura dos gradis e caixilharia e;

- $\quad$ substituição dos vidros quebrados.

1989 - Foi realizado o serviço de avaliação do estado de conservação das estruturas e componentes de madeira. Foram diagnosticados os problemas encontrados, tendo sido também identificados os tipos de madeira empregados na edificação (as demais

\footnotetext{
${ }^{\text {A.6 }}$ A empresa COTTA LTDA. foi recomendada pelo IPHAN e Fundação Pró-Memória.

${ }^{\text {A.7 }}$ Após 2 dois anos a pintura encontrava-se em processo acelerado de desbotamento e proliferação de fungos.

${ }^{\text {A.8 }}$ Não foi localizado dentre os documentos existentes na FAU, nenhum Relatório onde constasse o resultado do serviço de prospecção mencionado.
} 
informações coletadas no laudo resultante deste serviço estão apresentadas resumidamente no Capítulo 5).

1990/1991 - A empresa ARESTA Arquitetura e Restauro Ltda. foi contratada para execução da obra de recuperação do telhado de ardósia, visando sanar os problemas constantes de infiltração de águas pluviais, possibilitando as obras de restauro das áreas internas. Para tanto, foi realizado o escoramento provisório do forro, nas zonas que apresentavam risco de desabamento durante a execução do serviço. Para o escoramento do forro foram empregadas chapas de compensado com placas de isopor, de modo a garantir a proteção da pintura. Em alguns casos, as chapas de compensado foram fixadas por pinos metálicos aos caibros de sustentação do forro, em outros por pontaletes de madeira. Nesta época realizou-se uma limpeza do sótão e impermeabilizou-se dos compensados dispostos entre a estrutura de sustentação do telhado e as telhas, utilizando asfalto modificado com polímero e elastômero. Apesar de ter sido considerada em bom estado, a estrutura de sustentação do telhado recebeu preventivamente um tratamento químico aplicado com pincel, para o qual havia sido especificado o uso de um dos seguintes produtos: Pentoxsuper ${ }^{\circledR}$, Penetrox ${ }^{\circledR}$, Xilofix ${ }^{\circledR}$ e Jimo Cupim ${ }^{\circledR}$ (Relatório TECNOMAD 161/89). As telhas inteiras foram lavadas com sabão neutro sob fricção de escova de aço para remoção da pulverulência impregnada e do material desagregado pela ação de chuvas ácidas. Posteriormente, foi aplicado silicone metílico, avaliado em laboratório quanto à sua função hidrorepelente e considerado adequado. As telhas foram fixadas com ganchos ou colchetes de alumínio, em substituição aos de cobre, utilizando espaçadores de neoprene para deixá- 
las suspensas sobre o compensado impermeabilizado. Para substituição das telhas muito deterioradas utilizou-se ardósia proveniente de Minas Gerais (ORNSTEIN, 1993). 1991 - Neste ano a atividade de restauração pictórica dos murais teve início. Foram realizadas as sondagens e prospecções cromáticas para o reconhecimento das pinturas artísticas originais, recobertas por grossas camadas de pinturas posteriores. Após estes serviços foi iniciada a etapa de decapagem da pintura. Essas atividades seguiram as diretrizes apresentadas na Tese de Doutoramento da arquiteta Regina Tirello (1999). Como conclusões obtidas após essa atividade tem-se que:

- as pinturas decorativas encontram-se entre o primeiro e quarto extrato de tinta;

- $\quad$ as camadas posteriores devem ter sido aplicadas após a instalação da FAU, em 1949;

- o primeiro extrato caracteriza-se por pinturas lisas, decorativas e vestígios de cola e/ou resina indicando o uso de papel de parede. Para a demarcação das figuras nas pinturas decorativas foram empregadas as técnicas do spolvero $^{\text {A.9 }}$, moldes de cartão e máscaras simples com moldes (este último nos forros, possibilitando a repetição dos motivos pintados);

- foram utilizadas cores fortes e escuras, predominantemente amarelo ocre, verde musgo, vermelho, azul cobalto e marrom;

\footnotetext{
A.9 Spolvero - método utilizado para marcar os desenhos em grandes áreas a serem preenchidas com tintas. Sobre papel grosso se executa o desenho a ser transferido para a parede. Ao longo de suas linhas são feitos pequenos furos distantes poucos milímetros. Esse papel é fixado sobre o substrato e com um pano cheio de pigmento escuro se bate ao longo das linhas furadas. O pó penetra através dos furos deixando sobre a parede uma linha pontilhada que serve de base ao traço.
} 
- o douramento foi feito pelo método do guazzo ${ }^{\text {A.10 }}$, utilizando a folha metálica dourada como cor;

- encontrou-se pinturas características de diferentes épocas e estilos em um mesmo cômodo, que indicam alterações na decoração intrínseca à edificação e;

- as madeiras de revestimento foram escurecidas com mordentes (hall principal), policromadas, imitando outros materiais ou pintadas em tons amarelos, com uma camada de verniz.

1992/1993 - Contratação da CIMEL - Comércio, Instalações e Montagens Elétricas S.A. para substituição e reforma de ampliação das instalações elétricas do porão, visando minorar o risco de incêndios. Para tanto, foram especificados:

- a substituição do quadro da chave geral, de tomadas e dos eletrodutos por novos em material antichama;

- a instalação de novos eletrodutos, caixas de passagem, luminárias, interruptores; etc.

Por limitação orçamentária foram realizadas somente as substituições do quadro de chave geral, da fiação elétrica, instalação de luminárias e interruptores, ficando pendente a substituição dos condutores alimentadores dos quadros a partir do quadro de distribuição geral, bem como, dos condutores dos circuitos terminais do solo (SIMÕES, 1993).

1995 - Apresentação do projeto de Arquitetura Paisagística, elaborado pelos arquitetos Maria de Assunção Ribeiro Franco, Sílvio Soares Macedo e Vladimir Bartalini, ao Conselho Curador da FAU.

\footnotetext{
${ }^{\text {A.10 }}$ Método do guazzo - não foi localizada a descrição desta técnica.
} 
1997 - A empresa ATZO NOBEL foi contatada para serviço de limpeza e preparação das fachadas da Vila Penteado para nova pintura. Foi solicitado ao Conselho Curador que contatasse o IPT para a reconstituição do traço de argamassa empregado, visando recuperar partes do revestimento que encontravam-se deterioradas. Não há informações que esses serviços tenham sido realizados.

\section{A.3.3 Estado de conservação da edificação}

Salienta-se neste item algumas observações feitas durante a vistoria preliminar do estado de conservação do forro. Contudo, como este estudo não abrange a edificação como um todo, recomenda-se uma avaliação mais precisa do estado atual da construção, caso esta seja objeto de novas intervenções.

De modo geral, excluindo o elemento de forro que foi abordado no Capítulo 5, a edificação encontra-se em bom estado de conservação, o que não implica na ausência de melhorias de suas acomodações.

\section{a)Estrutura, revestimento e acabamento}

Não foram detectados problemas estruturais significativos, exceto no forro do cômodo S10, comentado no item 5.4.1.

O revestimento interno das paredes apresenta-se bem conservado na maioria dos cômodos. Porém, no cômodo T15 foi identificada uma infiltração próxima à porta de comunicação com o hall principal cuja origem precisa ser investigada. 
Nos cômodos S04 e S06 foram observados problemas oriundos de presença de umidade nos forros em madeira, com severo apodrecimento no S04. Nos demais forros em madeira, observou-se em alguns casos a deterioração do material de calafetagem.

Foi também observada a existência de alterações do projeto original. A exemplo disto, ressalta-se o fechamento das comunicações entre os cômodos S19 e S20. Esta intervenção foi explicitada pelo aparecimento de fissuras características de movimentação higrotérmica diferencial (Figura A.6).

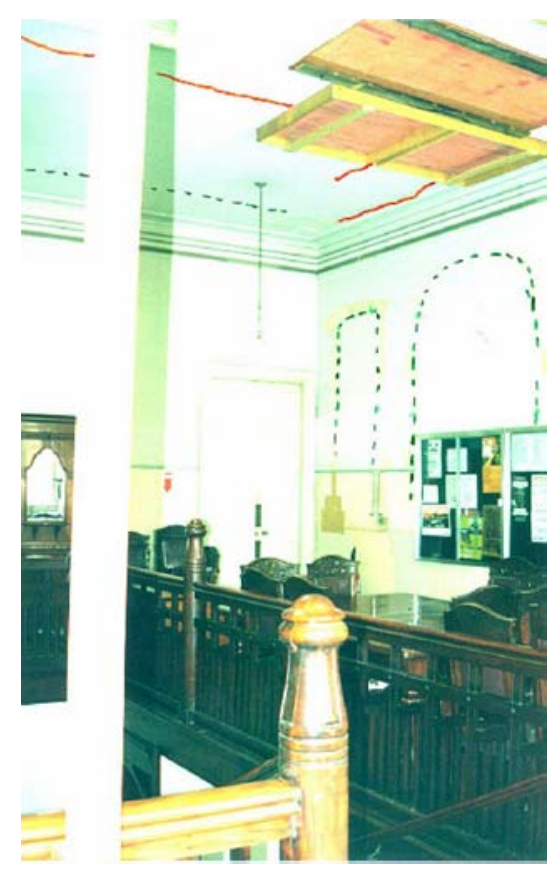

Figura A. 6 - Alteração do projeto original pelo fechamento da comunicação em arco dos cômodos S19 e S20.

$\mathrm{Na}$ ocasião da vistoria preliminar, a restauração das pinturas murais encontrava-se em andamento nos cômodos T17 e S16, e concluídas nos cômodos T13, T15B (Figura A.3). 
$\mathrm{Na}$ fachada foi verificada a ocorrência de manchas de umidade e focos de bolor, predominantemente na zona de respingo e, em alguns casos, também se encontram próximos à cobertura (Figura A.7).
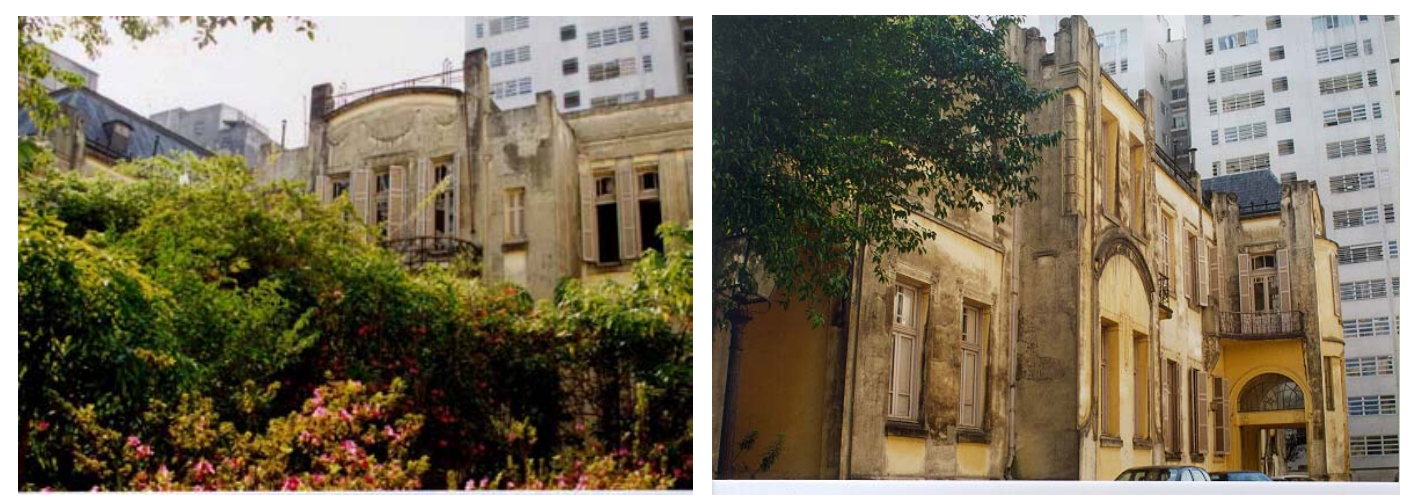

Figura A. 7 - Estado de deterioração do revestimento das fachadas em 1997.

\section{b) Cobertura}

Na ocasião da vistoria preliminar, a cobertura encontrava-se em obras e não foi vistoriada, uma vez que não era o objeto de estudo principal e por ser de difícil acesso. 


\section{ANEXO B - EVENTOS SOBRE A PRESERVAÇÃO E RESTAURAÇÃO DO PATRIMÔNIO HISTÓRICO}

\section{MUNDIAL EDIFICADO E PRINCÍPIOS DEFINIDOS DURANTE OS MESMOS}

Tabela B- 1 Quadro resumo das recomendações das Cartas Patrimoniais

\begin{tabular}{|c|c|c|c|c|}
\hline Evento & O que restaurar? & Princípios & Por quê restaurar? & Como restaurar \\
\hline \multirow[t]{3}{*}{$\begin{array}{l}\text { Atenas } \\
1933 \\
\text { Sociedade } \\
\text { das Nações }\end{array}$} & $\begin{aligned} & \text { Construções Repetitivas: } \\
& \text { alguns exemplares; } \\
\Leftrightarrow & \text { Parte que constitua uma } \\
& \text { lembrança ou valor real; }\end{aligned}$ & \begin{tabular}{l}
\multirow{H}{*}{$\begin{array}{l}\text { Evitar alterações do estilo, } \\
\text { aspecto e caráter do edifício; }\end{array}$} \\
$\Leftrightarrow \quad \begin{array}{l}\text { Excepcionalmente, } \\
\text { transplantação de elementos }\end{array}$ \\
incômodos por sua situação; \\
$\Leftrightarrow \quad$ Respeitar o caráter e a \\
fisionomia da cidade na \\
vizinhança do monumento \\
(supressão de publicidade, \\
presença abusiva de postes, \\
fios telegráficos, indústrias).
\end{tabular} & $\begin{array}{ll} & \text { O Patrimônio Histórico } \\
& \text { constitui a alma coletiva de } \\
& \text { uma nação e sua tradição; } \\
\Leftrightarrow & \begin{array}{l}\text { Direito da coletividade em } \\
\text { relação à propriedade }\end{array} \\
\text { privada de um bem } \\
\text { histórico; }\end{array}$ & $\begin{aligned} & \begin{array}{l}\text { Análise e diagnóstico dos } \\
\text { danos antes da intervenção; }\end{array} \\
\Leftrightarrow & \text { Abandono de reconstituições } \\
& \text { integrais; } \\
\Leftrightarrow & \text { Saneamento das edificações } \\
& \text { insalubres (cortiços) ou } \\
& \text { substituição por áreas verdes; } \\
\Leftrightarrow & \text { Assegurar a utilização do } \\
& \text { monumento, adequando-a ao } \\
& \text { caráter histórico ou artístico } \\
& \text { da edificação; }\end{aligned}$ \\
\hline & \multicolumn{2}{|c|}{ Obrigações das instituições de preservação } & Materiais de restauro & O que fica proibido? \\
\hline & \multicolumn{2}{|c|}{$\begin{array}{l}\Leftrightarrow \text { Salvaguardar as obras primas nas quais as civilizações tenham } \\
\text { expressado seu desenvolvimento; } \\
\Leftrightarrow \quad \begin{array}{l}\text { Inventariar seus bens; (Relações reunidas no Escritório Nacional } \\
\text { de Museus) }\end{array} \\
\Leftrightarrow \text { Escolher com critério pré-definido o que deve ser preservado; } \\
\Leftrightarrow \text { Publicação de procedimentos e métodos de conservação; }\end{array}$} & 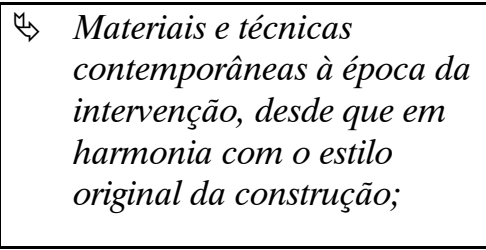 & $\begin{array}{l}\text { Construção de edificações } \\
\quad \text { novas mantendo estilos } \\
\quad \text { passados em zonas históricas; } \\
\text { Exemplo de exceção: } \\
\text { Reconstrução pós-guerra da } \\
\text { Europa; }\end{array}$ \\
\hline
\end{tabular}




\begin{tabular}{|c|c|c|c|}
\hline Evento & Princípios & Por quê restaurar? & Como restaurar \\
\hline \multirow[t]{3}{*}{$\begin{array}{c}\text { Veneza } \\
1964 \\
\text { COSMOS }\end{array}$} & 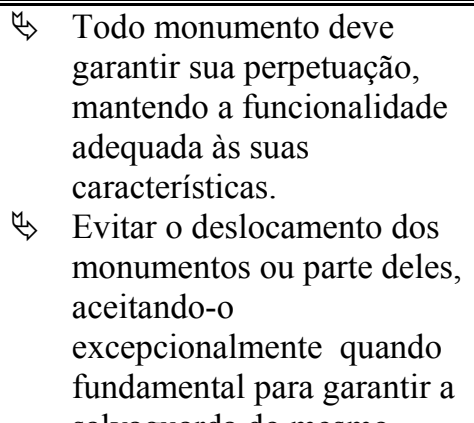 & $\begin{array}{l}\text { O Patrimônio Cultural é } \\
\text { considerado bem coletivo } \\
\text { perante as gerações futuras; } \\
\Leftrightarrow \quad \begin{array}{l}\text { Conservar e revelar os } \\
\text { valores estéticos e históricos } \\
\text { do monumento; }\end{array}\end{array}$ & \multirow{3}{*}{ 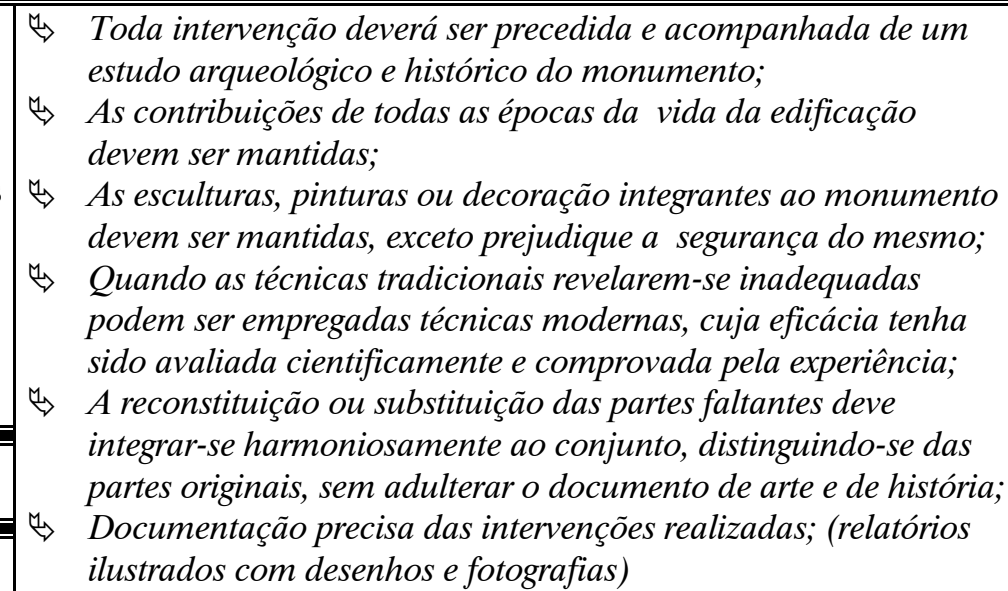 } \\
\hline & $\begin{array}{l}\leftrightarrow \text { A intervenção finda onde } \\
\text { comeca a hipótese; }\end{array}$ & O que fica proibido? & \\
\hline & & $\stackrel{\leftrightarrow}{\Rightarrow}$ Reconstrução & \\
\hline
\end{tabular}




\begin{tabular}{|c|c|c|c|}
\hline Evento & Princípios & Por quê restaurar? & Como restaurar \\
\hline \multirow[t]{3}{*}{$\begin{array}{l}\text { Quito } \\
1967 \\
\text { O.E.A. }\end{array}$} & $\begin{array}{l}\stackrel{\leftrightarrow}{\Rightarrow} \text { Todo monumento deve } \\
\text { cumprir uma função social; }\end{array}$ & 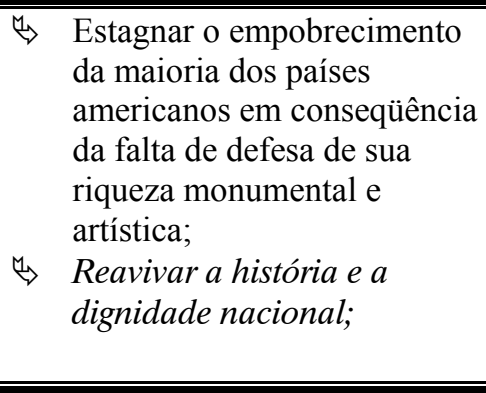 & 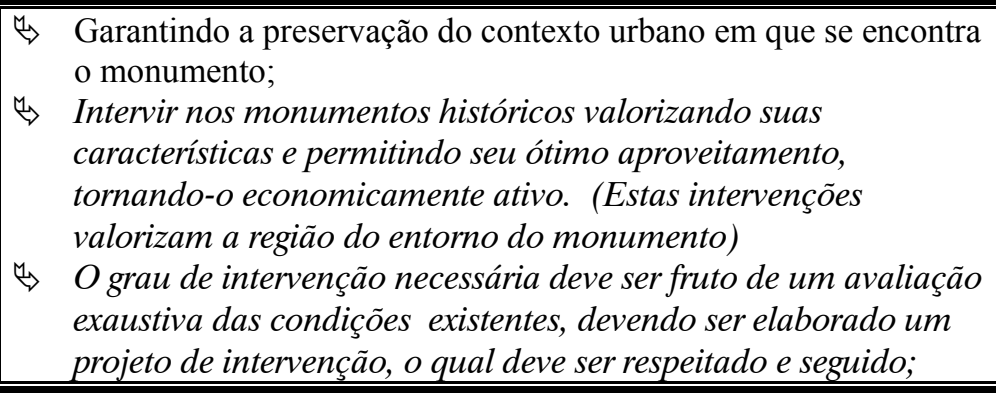 \\
\hline & \multicolumn{2}{|c|}{ Obrigações das instituições de preservação } & Observações \\
\hline & \multicolumn{2}{|c|}{$\begin{array}{l}\text { Intervir na política de desenvolvimento urbano evitando a } \\
\text { devastação do Patrimônio Histórico e Artístico, exigindo de todo } \\
\text { plano urbanístico a previsão da integração com centros ou } \\
\text { complexos históricos; } \\
\Leftrightarrow \text { Intermediar o auxílio do Estado (fiscal) para garantir a } \\
\text { conservação e utilização do seu Patrimônio Histórico e Artístico, } \\
\text { incentivando a participação da iniciativa privada; }\end{array}$} & $\begin{array}{l}\Rightarrow \text { " a afluência turística determinada pela revalorização adequada de } \\
\text { um monumento assegura a recuperação rápida do capital } \\
\text { investido nesse fim;” } \\
\Leftrightarrow \text { " a atividade turística que se origina da apresentação adequada de } \\
\text { um monumento e que abandonada, determinaria sua extinção, traz } \\
\text { consigo uma profunda transformação econômica da região em } \\
\text { que esse monumento se acha inserido" }\end{array}$ \\
\hline
\end{tabular}


Continuação da Tabela B-1

\begin{tabular}{|c|c|c|c|}
\hline Evento & Princípios & Por quê restaurar? & (O que fica proibido? \\
\hline \multirow{5}{*}{$\begin{array}{l}\text { Paris } \\
1968 \\
\text { NESCO }\end{array}$} & 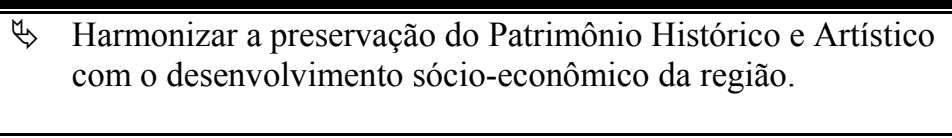 & 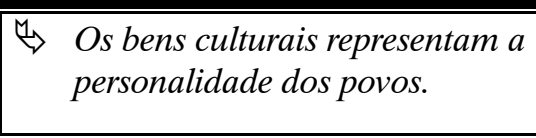 & $\begin{array}{l}\text { Publicidade comercial em } \\
\text { desarmonia com o ambiente } \\
\text { em que se insere. }\end{array}$ \\
\hline & Obrigações das instituições de preservação & \multicolumn{2}{|c|}{ Observações } \\
\hline & \multirow{3}{*}{ 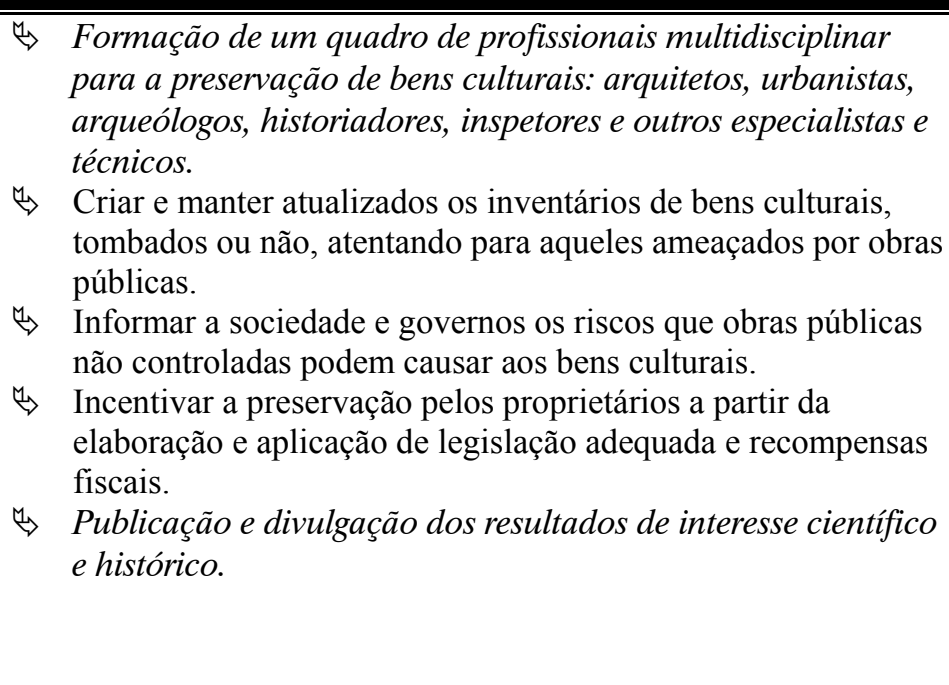 } & \multicolumn{2}{|c|}{ 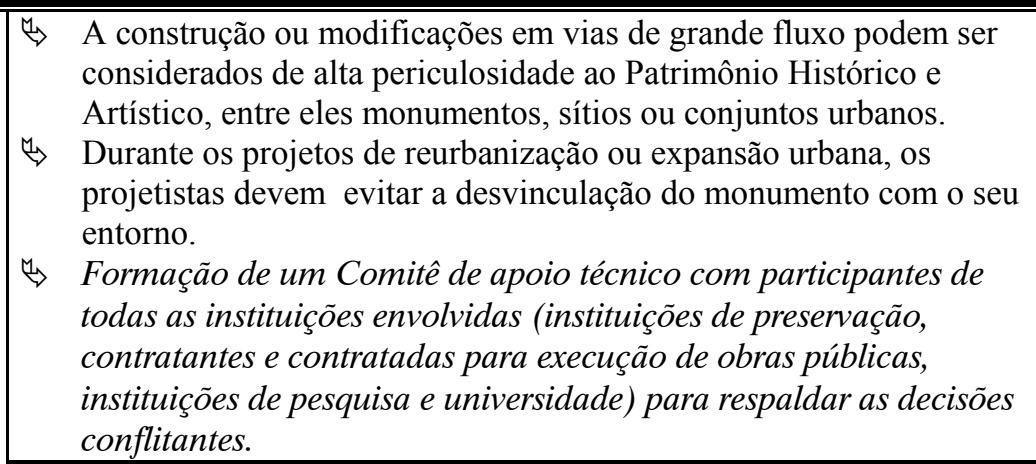 } \\
\hline & & \multicolumn{2}{|c|}{ O que restaurar? } \\
\hline & & \multicolumn{2}{|c|}{$\begin{array}{l}\begin{array}{l}\text { Proteger os monumentos, bem como seu entorno, ameaçados pela } \\
\text { execução de obras públicas ou em locais a serem transformados por } \\
\text { elas. }\end{array}\end{array}$} \\
\hline
\end{tabular}




\begin{tabular}{|c|c|c|c|}
\hline Evento & O que restaurar? & Obrigações das instituições de preservação & Observações \\
\hline $\begin{array}{c}\text { Brasília } \\
1970 \\
\text { Governadores } \\
\text { de Estado }\end{array}$ & $\begin{array}{l}\Leftrightarrow \text { Bens culturais de valor } \\
\text { nacional } \\
\text { (acervo arquivístico e } \\
\text { bibliográfico, monumentos, } \\
\text { igrejas, fortes, cemitérios, } \\
\text { parques, etc.) }\end{array}$ & $\begin{array}{ll}\Leftrightarrow & \text { Orientar os cursos de formação de mão de obra especializada } \\
\text { (nível superior e artesanal) e fornecer diretrizes para a } \\
\text { elaboração de legislação preservacionista dos Estados. } \\
\Leftrightarrow \quad \begin{array}{l}\text { Garantir o entrosamento entre confrarias religiosas e militares } \\
\text { visando preservar os bens de valor histórico sob sua tutela. }\end{array}\end{array}$ & $\begin{array}{ll}\Leftrightarrow & \text { Recomenda como utilização } \\
& \text { preferencial das edificações } \\
& \text { históricas casas de cultura ou } \\
& \text { repartições de atividades culturais. }\end{array}$ \\
\hline $\begin{array}{c}\text { Salvador } \\
1971 \\
\text { Governadores } \\
\text { de Estado }\end{array}$ & $\begin{array}{l}\text { Bens naturais e de } \\
\text { valor cultural } \\
\text { (paisagens, parques, } \\
\text { praias, acervos } \\
\text { arqueológicos, } \\
\text { conjuntos urbanos, } \\
\text { monumentos, bens } \\
\text { móveis, documentos, } \\
\text { livros, etc.) }\end{array}$ & $\begin{array}{l}\text { Henvênios com universidades para a criação e atualização do } \\
\text { inventário dos bens móveis. }\end{array}$ & $\begin{aligned} \Leftrightarrow & \text { BNH, CAPES, FINEP e órgãos } \\
& \text { congêneres, ficam responsáveis por } \\
& \text { financiar projetos de pesquisas e de } \\
& \text { formação de pessoal especializado } \\
& \text { e intervenções para preservação e } \\
& \text { valorização dos bens. } \\
\Leftrightarrow \quad & \text { Incentivou-se a atividade de } \\
& \text { turismo em regiões históricas ou } \\
& \text { com bens naturais preservados, } \\
& \text { adequando as edificações históricas } \\
& \text { às instalações de hotelaria. }\end{aligned}$ \\
\hline
\end{tabular}




\begin{tabular}{|c|c|c|c|}
\hline Evento & Princípios & $\begin{array}{c}\text { Obrigações das instituições de } \\
\text { preservação }\end{array}$ & Obrigações dos Estados Membros \\
\hline $\begin{array}{c}1972 \\
\text { UNESCO }\end{array}$ & $\begin{array}{l}\text { O bem cultural e natural com } \\
\text { valor excepcional deve ser } \\
\text { considerado patrimônio } \\
\text { mundial da humanidade. }\end{array}$ & $\begin{array}{l}\Leftrightarrow \quad \begin{array}{l}\text { Integrar a proteção dos bens com programas de } \\
\text { planejamento, atribuindo-lhes funções }\end{array} \\
\text { adequadas à sua integridade. } \\
\Leftrightarrow \quad \begin{array}{l}\text { Incentivar o estudo e pesquisas científicas e } \\
\text { técnicas para o aperfeiçoamento dos métodos }\end{array} \\
\text { de intervenção. } \\
\Leftrightarrow \quad \begin{array}{l}\text { Criar programas de educação e informação da } \\
\text { sociedade sobre seu patrimônio cultural e } \\
\text { nacional. }\end{array} \\
\end{array}$ & $\begin{array}{l}* \text { Criação e divulgação da Lista do Patrimônio } \\
\text { Mundial e sua atualização com periodicidade de } \\
2 \text { anos, bem como da Lista do Patrimônio } \\
\text { Mundial em Perigo. } \\
\Leftrightarrow \text { Criação do Fundo do Patrimônio. } \\
\Leftrightarrow \quad \text { Criação do Comitê do Patrimônio Mundial que } \\
\text { avaliará e distribuirá o auxílio aos bens que } \\
\text { julgarem necessário para diversas atividades. }\end{array}$ \\
\hline
\end{tabular}




\begin{tabular}{|c|c|c|}
\hline Evento & O que restaurar? & Como restaurar \\
\hline Carta do Restauro & $\begin{array}{l}\text { Obras de artes de qualquer época (pintura, } \\
\text { escultura - inclusive fragmentos; monumentos } \\
\text { arquitetônicos, conjuntos históricos, jardins, } \\
\text { parques, etc.) }\end{array}$ & \multirow{3}{*}{ 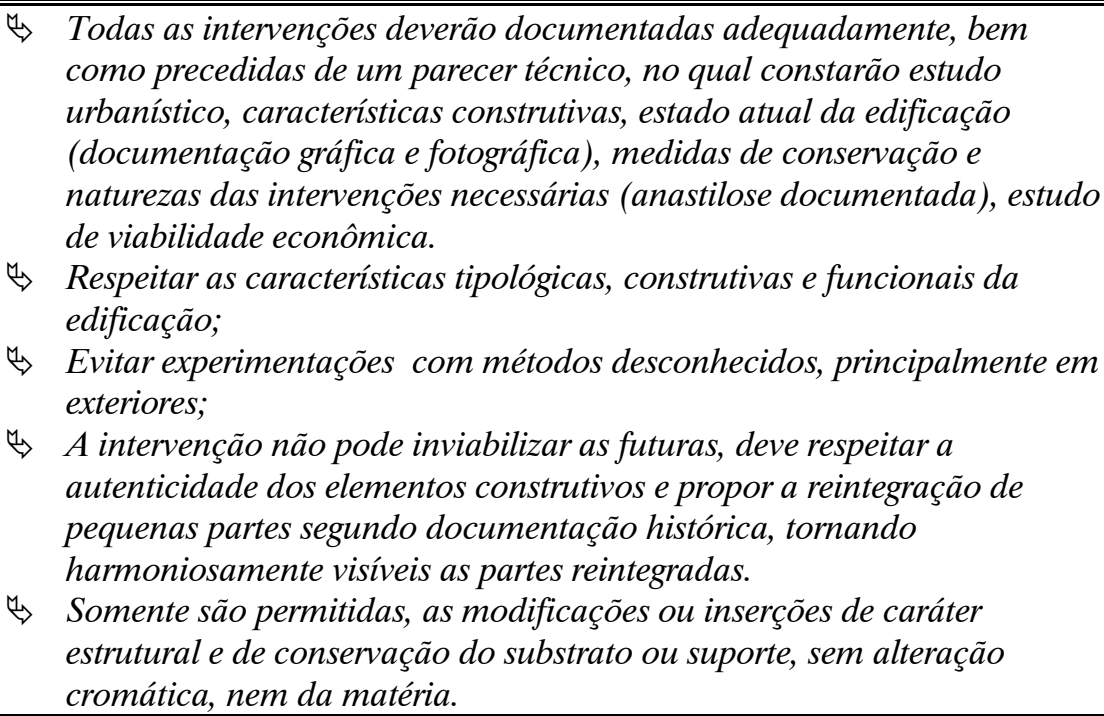 } \\
\hline Ministério de & Observações & \\
\hline $\begin{array}{l}\text { Instrução Pública - } \\
\text { Governo da Itália }\end{array}$ & $\begin{array}{l}\text { “...No caso de serem encontrados elementos } \\
\text { desprendidos de uma decoração de estuque, } \\
\text { ou de pintura, ou mosaico ou de opus sectile, } \\
\text { é necessário, antes e durante o seu translado, } \\
\text { mantê-los unidos com encolados de gesso, } \\
\text { com ataduras e adesivos adequados, de } \\
\text { modo que seja facilitado sua recomposição e } \\
\text { restauração em laboratório..." }\end{array}$ & \\
\hline
\end{tabular}




\begin{tabular}{|c|c|c|}
\hline Evento & Materiais de restauro & Como restaurar \\
\hline \multirow{3}{*}{$\begin{array}{l}\text { Carta do Restauro } \\
\qquad 1972 \\
\text { Ministério de } \\
\text { Instrução Pública - } \\
\text { Governo da Itália }\end{array}$} & $\begin{array}{l}\text { Novos procedimentos e materiais deverão ser } \\
\text { avaliados pelo Instituto Central de } \\
\text { Restauração; }\end{array}$ & \multirow{3}{*}{$\begin{array}{l}\Leftrightarrow \text { Evitar combinação de materiais diferentes e anacrônicos nas partes } \\
\text { restauradas, o que pode ser agressivo do ponto de vista cromático; } \\
\Leftrightarrow \text { As limpezas deverão respeitar a patina e eventuais vernizes antigos; } \\
\Leftrightarrow \text { Durante a remoção de pinturas murais deverão ser empregados meios } \\
\text { mecânicos com controle pinacoscópio, ou por meios químicos voláteis e } \\
\text { neutralizáveis, sem fixarem-se sobre os estratos de pinturas; ou ainda o } \\
\text { método italiano denominado strappo, devido à possibilidade de } \\
\text { recuperação da sinopia preparatória dos afrescos. }\end{array}$} \\
\hline & O que fica proibido? & \\
\hline & $\begin{array}{l}\Leftrightarrow \text { Aditamentos de estilos com a remoções ou } \\
\text { demoliçôes das partes relacionadas com a } \\
\text { trajetória da obra através do tempo; } \\
\Leftrightarrow \quad \text { Remoção, reconstrução e translado, exceto } \\
\text { seja necessário para sua conservação; } \\
\Leftrightarrow \quad \text { Alteração das condições de acesso ou } \\
\text { ambientais; }\end{array}$ & \\
\hline
\end{tabular}




\begin{tabular}{|c|c|c|}
\hline Evento & O que restaurar? & Princípios \\
\hline \multirow{3}{*}{$\begin{array}{l}\text { Amsterdã } \\
1975 \\
\text { Conselho da } \\
\text { Europa }\end{array}$} & $\begin{array}{l}\text { Cidades históricas, bairros urbanos antigos e aldeias tradicionais, } \\
\text { optando pelos exemplares de importante valor histórico, bem } \\
\text { como alguns edifícios modestos. }\end{array}$ & $\begin{array}{ll}\text { A preservação é essencial para a manutenção da identidade da } \\
\text { sociedade e contribuir economicamente devido à adequação de } \\
\text { novos usos; }\end{array}$ \\
\hline & Obrigações das instituições de preservação & Como restaurar \\
\hline & $\begin{array}{l} \\
\Leftrightarrow \text { Elaborar relatórios periódicos sobre o estado do } \\
\text { desenvolvimento dos trabalhos de conservação arquitetônica nos } \\
\text { países europeus, de forma a permitir a troca de experiências; } \\
\Leftrightarrow \quad \begin{array}{l}\text { Incentivar as pesquisas de caráter fundamental, bem como a } \\
\text { programas de educação e desenvolvimento cultural; }\end{array} \\
\Leftrightarrow \quad \begin{array}{l}\text { Organizar o inventário das construções, dos conjuntos } \\
\text { arquitetônicos e dos sítios e sua zona de influência; }\end{array} \\
\end{array}$ & $\begin{array}{l}{ }^{\Perp} \\
\text { A reabilitação de centros históricos deve ser previamente } \\
\text { avaliado, após reunir a documentação sobre materiais e técnicas e } \\
\text { análise de custos; }\end{array}$ \\
\hline
\end{tabular}




\begin{tabular}{|c|c|c|c|c|c|c|}
\hline Evento & & Por quê restaurar? & Princípios & \multicolumn{3}{|c|}{ Como restaurar } \\
\hline \multirow{3}{*}{$\begin{array}{c}\text { Nairobi } \\
1976 \\
\text { UNESCO }\end{array}$} & $\Leftrightarrow$ & $\begin{array}{l}\text { Evitar a uniformização e a } \\
\text { despersonalização da a } \\
\text { expressão cultural da } \\
\text { sociedade, garantindo sua } \\
\text { importância para o testemunho } \\
\text { histórico; }\end{array}$ & 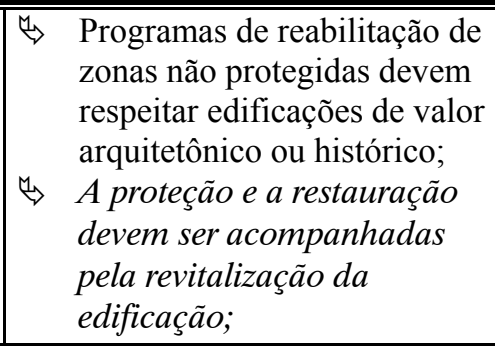 & $\begin{aligned} & \Leftrightarrow \text { Todos as intervenções deve } \\
& \text { científicos e estudos multid } \\
& \text { sociólogos, economistas, ec } \\
& \text { casos de intervençôes emer } \\
& \Leftrightarrow \text { Respeitar as manifestaçôes } \\
& \text { edificação ao longo do tem } \\
& \Leftrightarrow \quad \text { Respeitar as normas gerais } \\
& \text { catástrofes naturais; }\end{aligned}$ & & $\begin{array}{l}\text { r baseadas em princípios } \\
\text { linares (arquitetos, urbanistas, } \\
\text { os, paisagistas, etc.), exceto nos } \\
\text { iais; } \\
\text { a incorporação de elementos a } \\
\text { egurança relativas a incêndios e }\end{array}$ \\
\hline & \multicolumn{4}{|c|}{ Obrigações das instituições de preservação } & & O que fica proibido? \\
\hline & & \multicolumn{3}{|c|}{$\begin{array}{l}\text { Revisar as leis relativas ao planejamento físico, harmonizando o patrimônio arquitetônico e a política } \\
\text { habitacional; } \\
\text { Estabelecer, aprovar de planos e normas de salvaguarda e controlar sua aplicação; } \\
\text { Buscar o incentivo governamental, como: fiscal, subsídios ou empréstimos aos proprietários } \\
\text { particulares; } \\
\text { Incentivar e organizar cursos de formação de técnicos e artesãos especializados em restauro; } \\
\text { Intercâmbio de informações e publicaçôes científicas e técnicas; } \\
\text { Organização de seminários e de grupos de trabalho sobre temas específicos; }\end{array}$} & & $\begin{array}{l}\text { Isolamento da edificação } \\
\text { através da supressão de seu } \\
\text { entorno; } \\
\text { Deslocamento da edificação; } \\
\text { Desfiguração do entorno da } \\
\text { edificação (painéis } \\
\text { publicitários, cabos elétricos } \\
\text { ou telefônicos, antenas, etc.) }\end{array}$ \\
\hline
\end{tabular}




\begin{tabular}{|c|c|c|c|}
\hline Evento & Princípios & Como restaurar & O que fica proibido? \\
\hline $\begin{array}{l}\text { Austrália } \\
1980 \\
\text { ICOSMOS }\end{array}$ & $\begin{array}{l}\leftrightarrow \text { A preservação deve limitar-se na } \\
\text { proteção e manutenção do bem; } \\
\leftrightarrow \quad \text { A restauração só deverá ser } \\
\text { efetivada se houver dados que } \\
\text { testemunhem o estado anterior do } \\
\text { bem e o restabelecimento conduzir } \\
\text { à valorização de sua significação } \\
\text { cultural. }\end{array}$ & 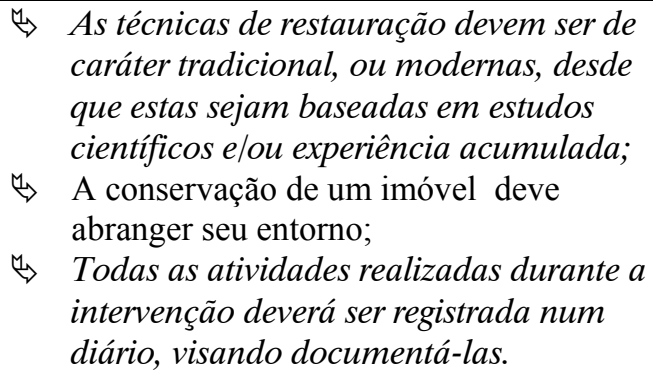 & 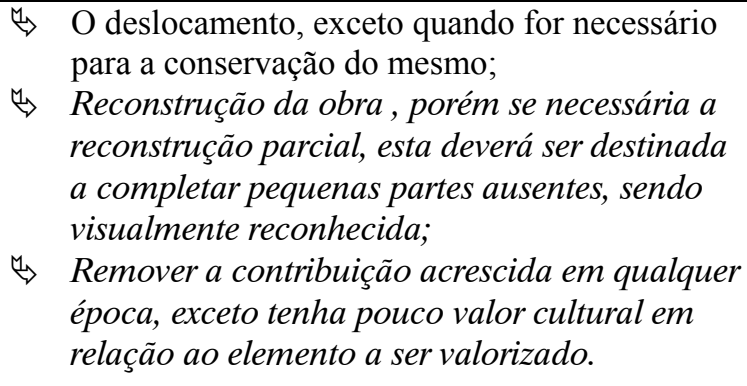 \\
\hline Evento & Princípios & Como restaurar & Obrigações das instituições de preservação \\
\hline $\begin{array}{l}\text { Washington } \\
\qquad 1986 \\
\text { ICOSMOS }\end{array}$ & 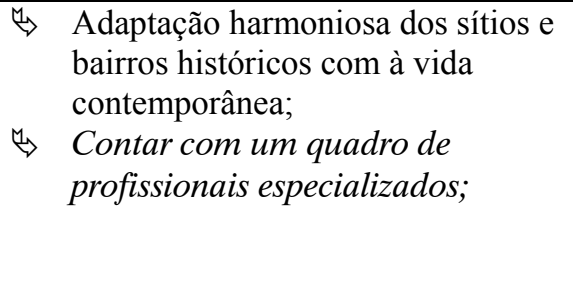 & $\begin{array}{l}\leftrightarrow \text { A intervenção deve ser precedida de } \\
\text { estudos multidisciplinares } \\
\text { (arqueológica, históricos, arquitetônicos, } \\
\text { técnicos, sociológicos e econômicos, } \\
\text { etc.); } \\
\leftrightarrow \text { Toda intervenção deverá ser } \\
\text { documentada; }\end{array}$ & $\begin{array}{l}\Leftrightarrow \quad \begin{array}{l}\text { Difundir a salvaguarda das cidades e bairros } \\
\text { históricos como política sócio-econômica; }\end{array} \\
\Leftrightarrow \quad \begin{array}{l}\text { Estimular a participação e o comprometimento } \\
\text { da sociedade, sendo esta indispensáveis para o }\end{array} \\
\text { sucesso dos programas de conservação; } \\
\Leftrightarrow \quad \begin{array}{l}\text { Definir as edificações que deverão ser } \\
\text { conservadas; }\end{array}\end{array}$ \\
\hline
\end{tabular}




\section{ANEXO C - ESTUDOS DE CASOS DE RESTAURAÇÕES NO PATRIMÔNIO HISTÓRICO E}

\section{ARQUITETÔNICO E MÉTODOS DE INVESTIGAÇÃO EMPREGADOS NO ESTUDO DE ARGAMASSA}

Tabela C- 1 Quadro resumo da metodologia de caracterização das argamassas históricas

\begin{tabular}{|c|c|c|c|c|}
\hline Casos Estudados & $\begin{array}{c}\text { Instituiçãa/ano da } \\
\text { publicação }\end{array}$ & Pesquisadores & Materiais & Ensaios empregados \\
\hline Diversos & 1981 & FRIZOT, M.; & argamassa romana & $\begin{array}{l}\text { ARGAMASSA } \\
\text { análise química; } \\
\text { espectrometria de absorção atômica; } \\
\text { eflorescência de raios X; } \\
\text { AGREGADOS } \\
\text { composição mineralógica } \\
\text { tamanho médio das partículas; } \\
\text { distribuição granulométrica; } \\
\text { índice de triagem" (regularidade da } \\
\text { distribuição simétrica do tamanho dos grãos } \\
\text { em torno da tamanho médio) }\end{array}$ \\
\hline $\begin{array}{c}\text { Diversos } \\
\text { (Baelo Claudia - Cádiz) }\end{array}$ & 1989 & $\begin{array}{l}\text { PUERTAS, F.; } \\
\text { BLANCO-VARELA, M. } \\
\text { T.; } \\
\text { PALOMO, A.; }\end{array}$ & $\begin{array}{l}\text { estuque e concreto } \\
\text { romano }\end{array}$ & $\begin{array}{l}\text { observação com lupa estereoscópica; } \\
\text { análise mineralógica por DRX; } \\
\text { determinação de sais solúveis em água; } \\
\text { cromatografia iônica (determinação de sais); } \\
\text { análise petrográfica; } \\
\text { porosidade; } \\
\text { densidade aparente. }\end{array}$ \\
\hline
\end{tabular}




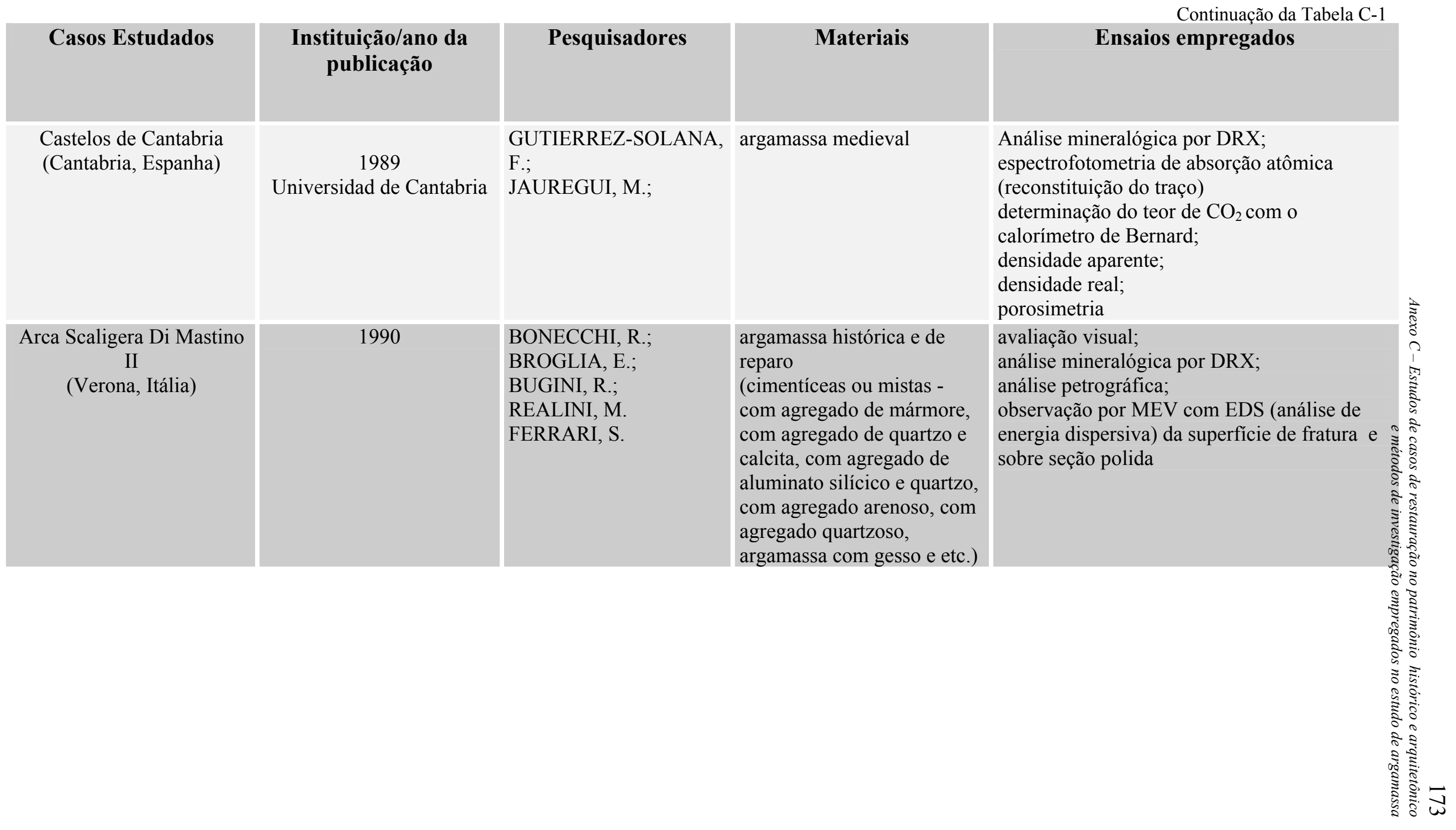




\begin{tabular}{|c|c|c|c|c|}
\hline Casos Estudados & $\begin{array}{l}\text { Instituição/ano da } \\
\text { publicação }\end{array}$ & Pesquisadores & Materiais & Ensaios empregados \\
\hline Edificações em Brasília & $\begin{array}{l}1991 \\
\text { Laboratoire Central de } \\
\text { Ponts et Chaussées }\end{array}$ & $\begin{array}{l}\text { RIBAS SILVA, } \\
\text { M.; } \\
\text { DELOYÉ, F. X. }\end{array}$ & $\begin{array}{l}\text { concreto; } \\
\text { (biodeterioração fúngica) }\end{array}$ & $\begin{array}{l}\text { análise mineralógica quantitativa; } \\
\text { observação por MEV; } \\
\text { registro de umidade relativa do ar; }\end{array}$ \\
\hline $\begin{array}{l}\text { Templo d' Amon } \\
\text { (Karnak) }\end{array}$ & $\begin{array}{l}1992 \\
\text { Laboratoire Central de } \\
\text { Ponts et Chaussées }\end{array}$ & $\begin{array}{l}\text { MARTINET, G.; } \\
\text { DELOYE, F.X.; } \\
\text { GOLVIN, J.C.; }\end{array}$ & argamassa de gesso & $\begin{array}{l}\text { análise mineralógica por DRX; } \\
\text { observação por MEV; }\end{array}$ \\
\hline $\begin{array}{l}\text { Templo d' Amon } \\
\text { (Karnak) }\end{array}$ & $\begin{array}{l}1992 \\
\text { Laboratoire Central de } \\
\text { Ponts et Chaussées }\end{array}$ & $\begin{array}{l}\text { MARTINET, G.; } \\
\text { DELOYE, F.X.; } \\
\text { LE ROUX, A; }\end{array}$ & $\begin{array}{l}\text { argamassa de restauro } \\
\text { (caracterização e } \\
\text { alterações) }\end{array}$ & $\begin{array}{l}\text { análise mineralógica por DRX; } \\
\text { observação por MEV; } \\
\text { análise petroquímica } \\
\text { (textura original e alterações) }\end{array}$ \\
\hline $\begin{array}{c}\text { Diversos } \\
\text { (Montreal e Quebec) }\end{array}$ & $\begin{array}{c}1992 \\
\text { Université de Sherbrooke }\end{array}$ & SARKAR, S. L.; & argamassa renascentista & $\begin{array}{l}\text { análise por microscopia óptica; } \\
\text { análise mineralógica por DRX; } \\
\text { observação por MEV com EDX; }\end{array}$ \\
\hline $\begin{array}{l}\text { Memorial Victoria } \\
\text { (Calcutá) }\end{array}$ & $\begin{array}{l}1994 \\
\text { Université de Sherbrooke }\end{array}$ & $\begin{array}{l}\text { SARKAR, S. L.; } \\
\text { BHADRA, A. K.; } \\
\text { MANDAL, P. K.; }\end{array}$ & $\begin{array}{l}\text { argamassa e rocha } \\
\text { (caracterização e } \\
\text { deterioração) }\end{array}$ & $\begin{array}{l}\text { análise química; } \\
\text { análise petrográfica; } \\
\text { porosimetria; } \\
\text { análise térmica; } \\
\text { análise mineralógica por DRX; } \\
\text { observação por MEV com EDS; }\end{array}$ \\
\hline
\end{tabular}




Casos Estudados

Basílica de Santa Engracia (Zaragoza, Espanha)

Diversos
(Republica Dominicana)

Medina Azahara

\begin{tabular}{c}
1997 \\
University of Istanbul \\
\hline 1995
\end{tabular}

Patrimônio Edificado em

Itálica, Sevilha e Baelo

Claudia
1997

Instituto Eduardo Torroja

\section{Instituição/ano da publicação}

1995

Instituto Eduardo Torroja

LUXÁN, M. P.;
DORREGO, F.;

LABORDE, A.;

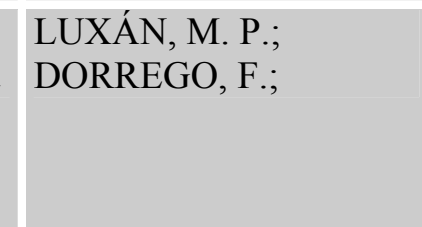

PUERTAS, F.; BLANCO VARELA,

T.; PALOMO, A.;

GULEÇ, A.;

TULUN, T.;

SÁIZ-JIMÉNEZ; C.;

Instituto de Recursos

Naturales y Agrobiologia

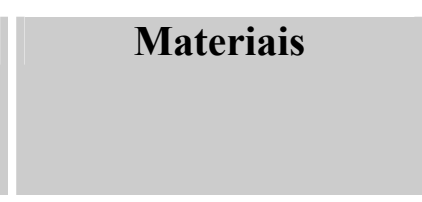

argamassas de gesso

análise por microscopia óptica;

observação porMEV e EDS;

análise mineralógica por DRX;

espectroscopia de infravermelho;

granulometria laser do aglomerante;

granulometria do agregado.

argamassas do século observação por MEV com EDS;

análise térmica;

espectroscopia de infra-vermelho;

análise por microscopia óptica;

análise química;

observação com lupa estereoscópica;

análise mineralógica por DRX;

determinação de solubilidade em água/HCl

a $20 \%$.

avaliação visual;

peneiramento do agregado;

análise petrográfica;

porosimetria;

análise mineralógica por DRX.

mosaico e argamassa

observação por MEV; 


\section{ANEXO D - REGISTRO FOTOGRÁFICO DA VISTORIA PRELIMINAR DO FORRO DA EDIFICAÇÃO VILA PENTEADO EM}

O registro fotográfico apresentado neste anexo foi o mesmo apresentado no Relatório com a descrição do estado de conservação do forro em estuque da edificação em 1997 entregue à FAUUSP ao final daquele ano. Algumas das fotos já foram apresentadas no corpo do texto da dissertação e no Anexo A. As fissuras com marcação no forro foram indicadas na maioria dos casos com hidrocor verde e as fissuras não assinaladas no forro foram indicadas nas fotos de laranja ou vermelho.

Consta junto às fotos a identificação do cômodo, a sua área, o tipo de forro, a classificação do estado de conservação e a utilização do cômodo na ocasião. Os cômodos não fotografados encontravam-se chaveados durante a inspeção.

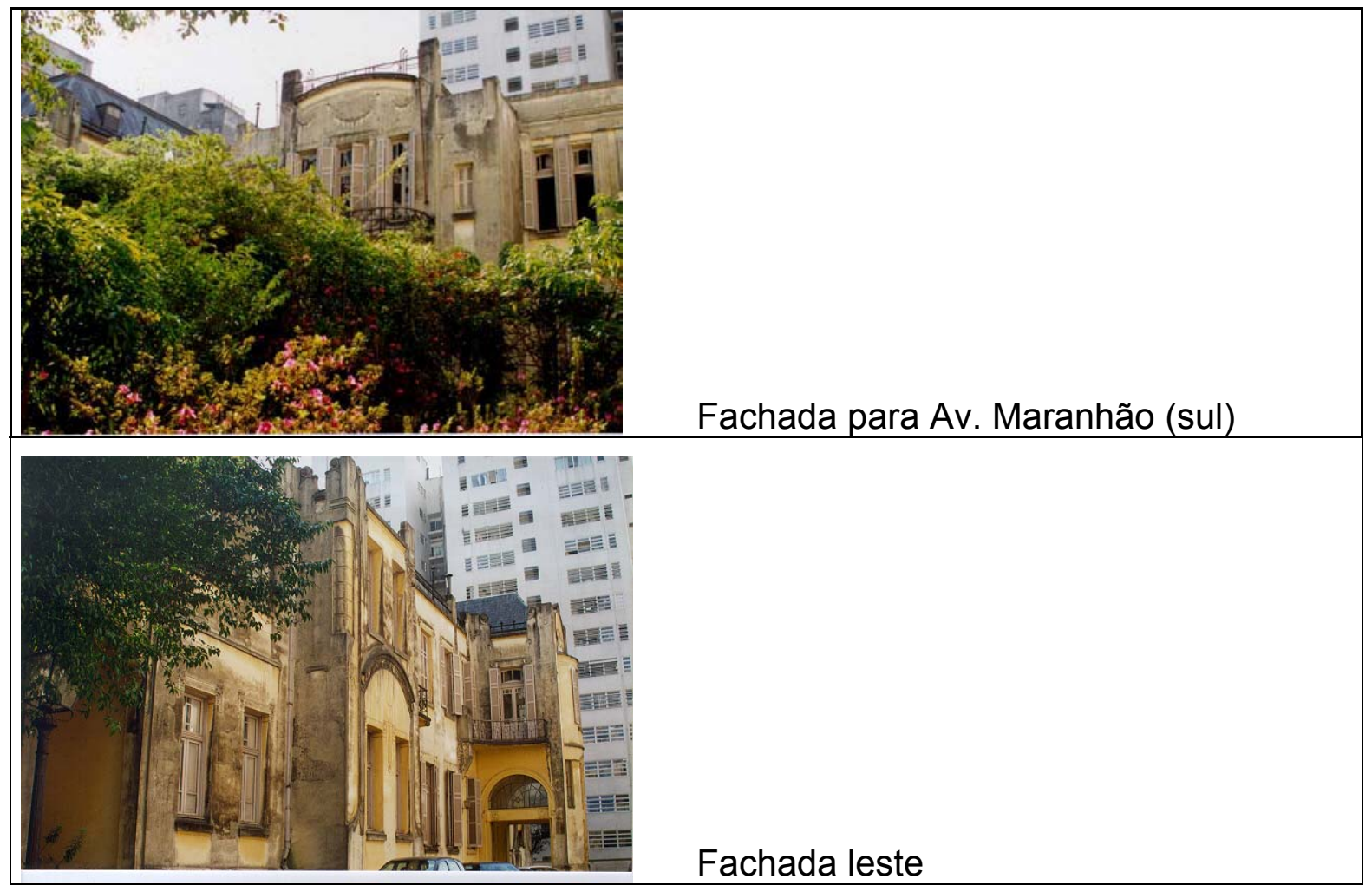



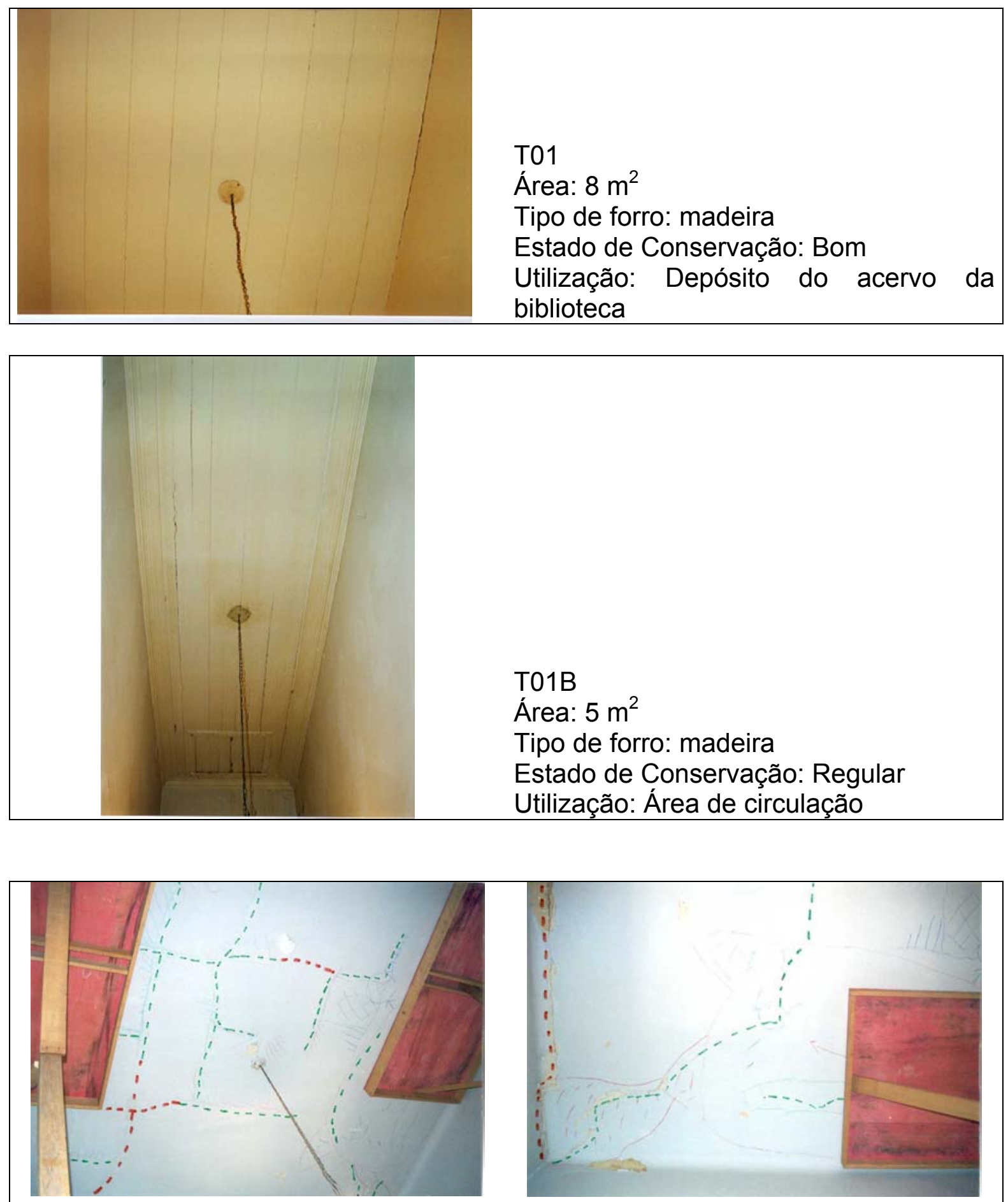

T03

Área: $18 \mathrm{~m}^{2}$

Tipo de forro: estuque

Estado de Conservação: Bastante fissurado

Utilização: Cozinha dos funcionários 

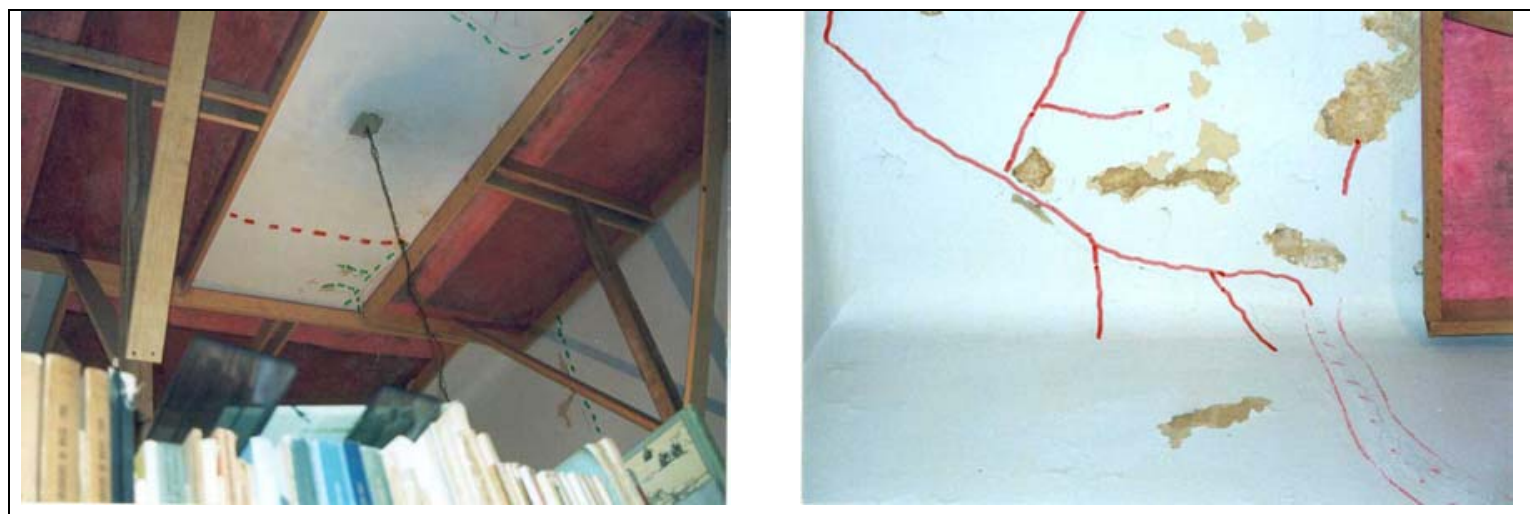

T04

Área: $15 \mathrm{~m}^{2}$

Tipo de forro: estuque

Estado de Conservação: Pouco fissurado

Utilização: Depósito do acervo da biblioteca
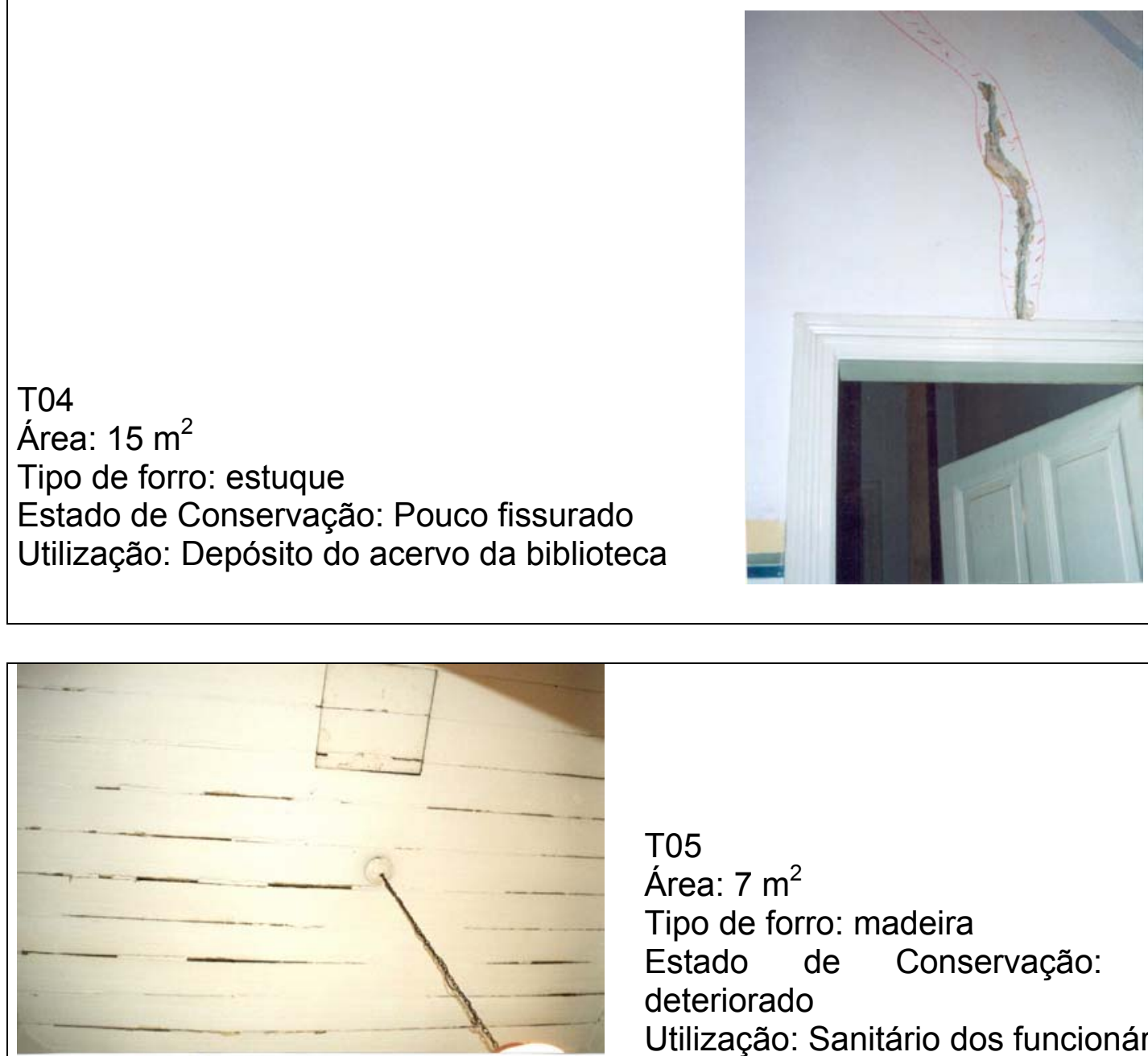

T05

Área: $7 \mathrm{~m}^{2}$

Tipo de forro: madeira

Estado de Conservação: Pouco deteriorado

Utilização: Sanitário dos funcionários 

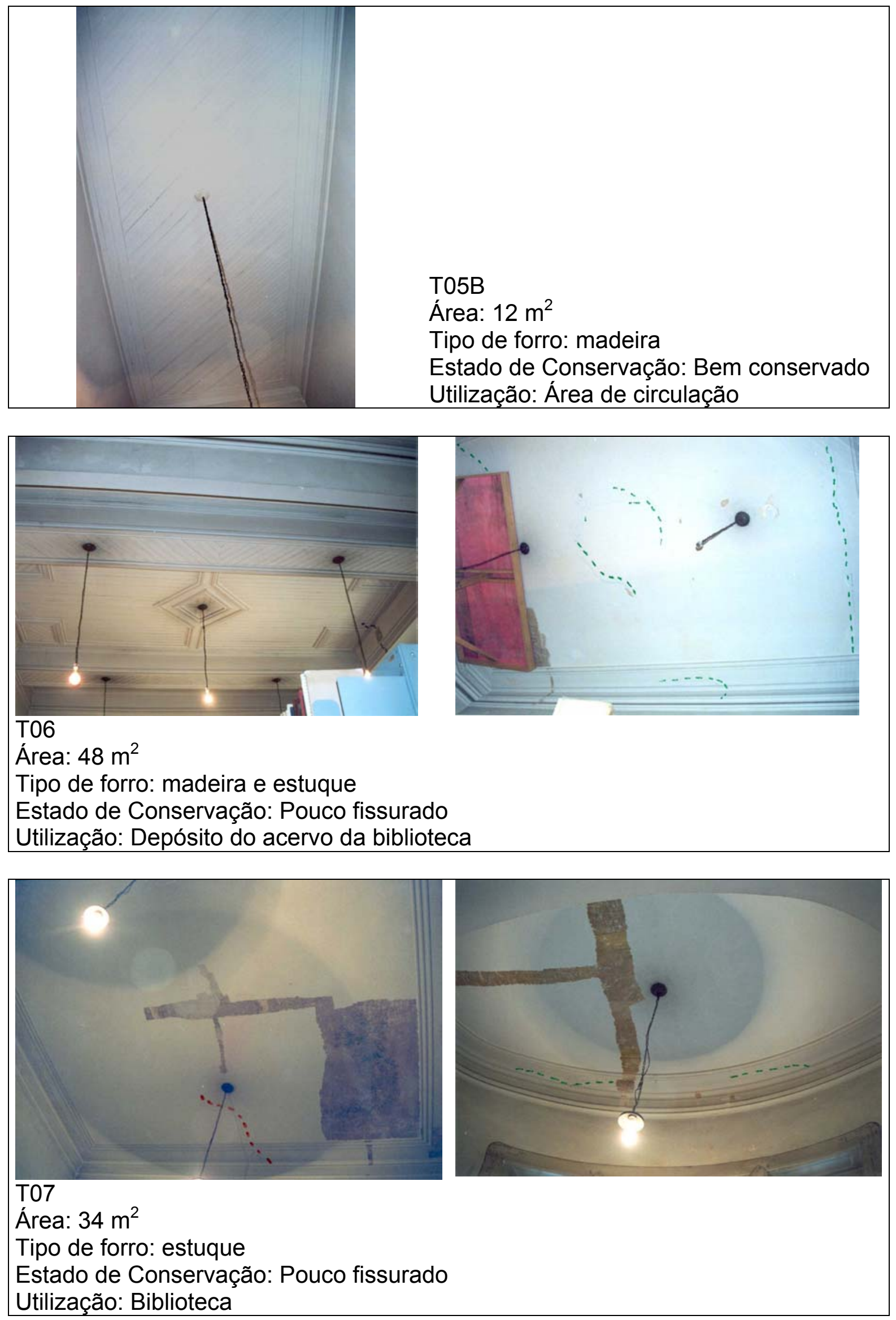

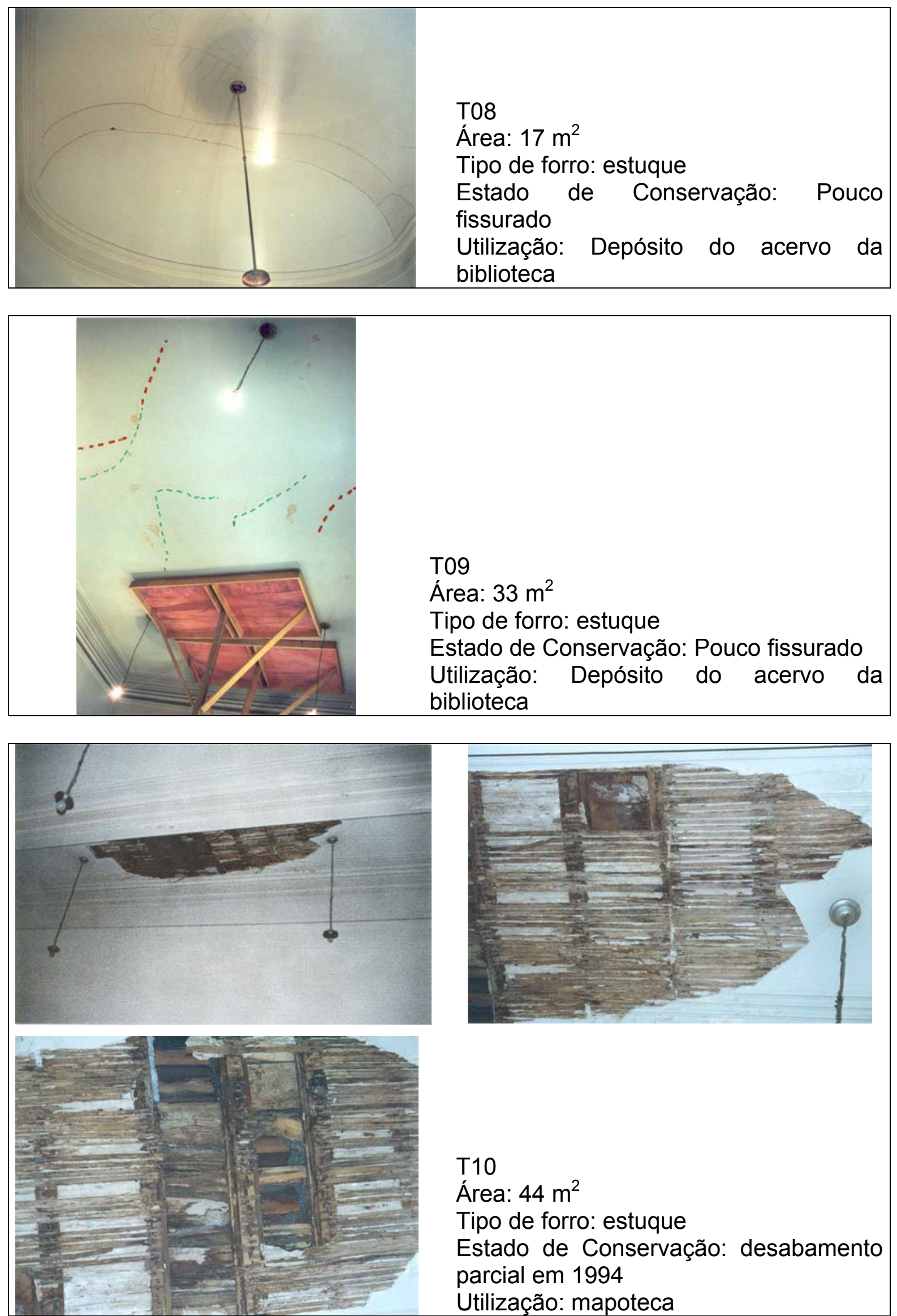

T10

Área: $44 \mathrm{~m}^{2}$

Tipo de forro: estuque

Estado de Conservação: desabamento parcial em 1994

Utilização: mapoteca 

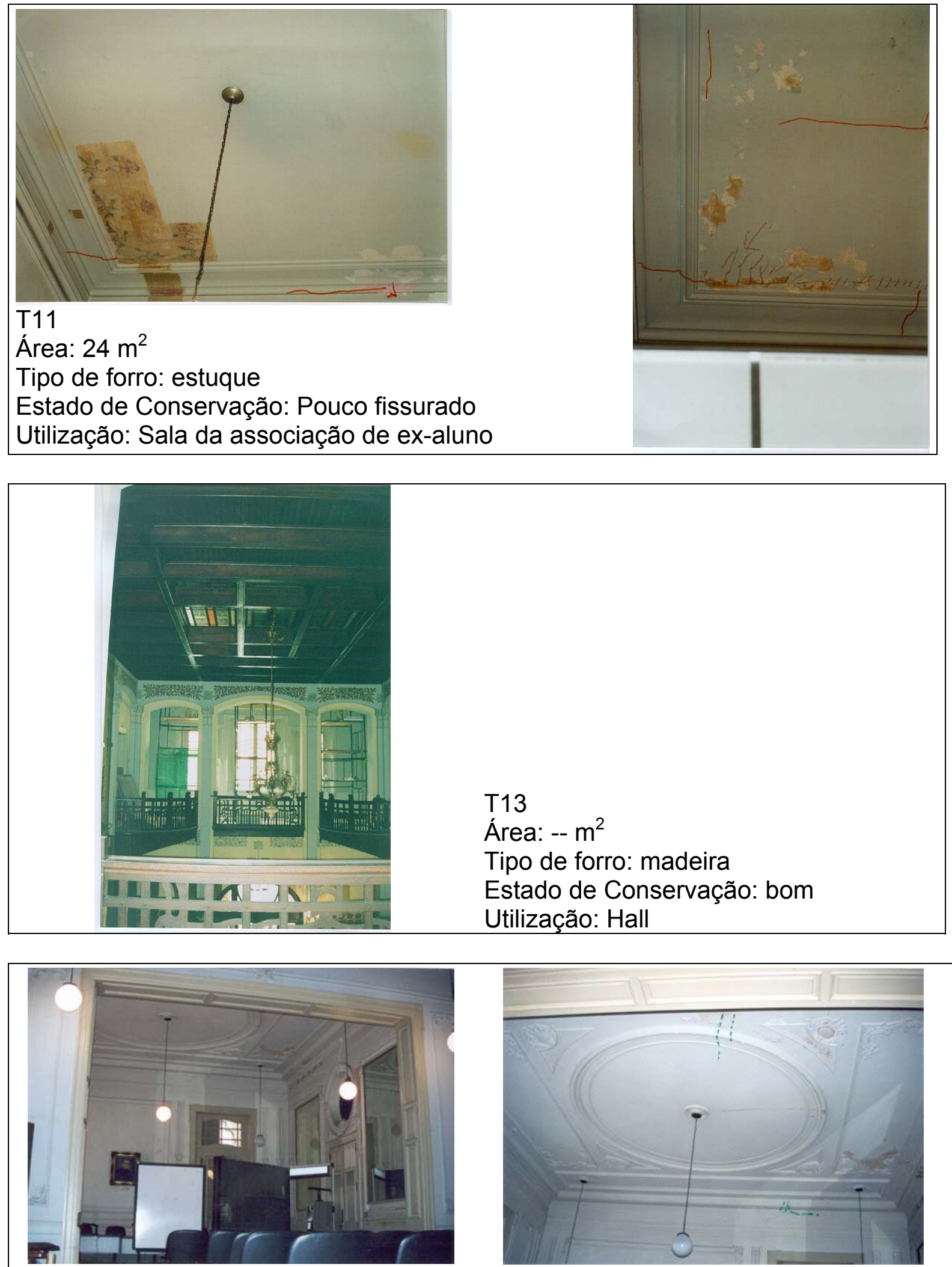

T15

Área: $94 \mathrm{~m}^{2}$

Tipo de forro: estuque

Estado de Conservação: Pouco fissurado

Utilização: Auditório (2 ambientes) 

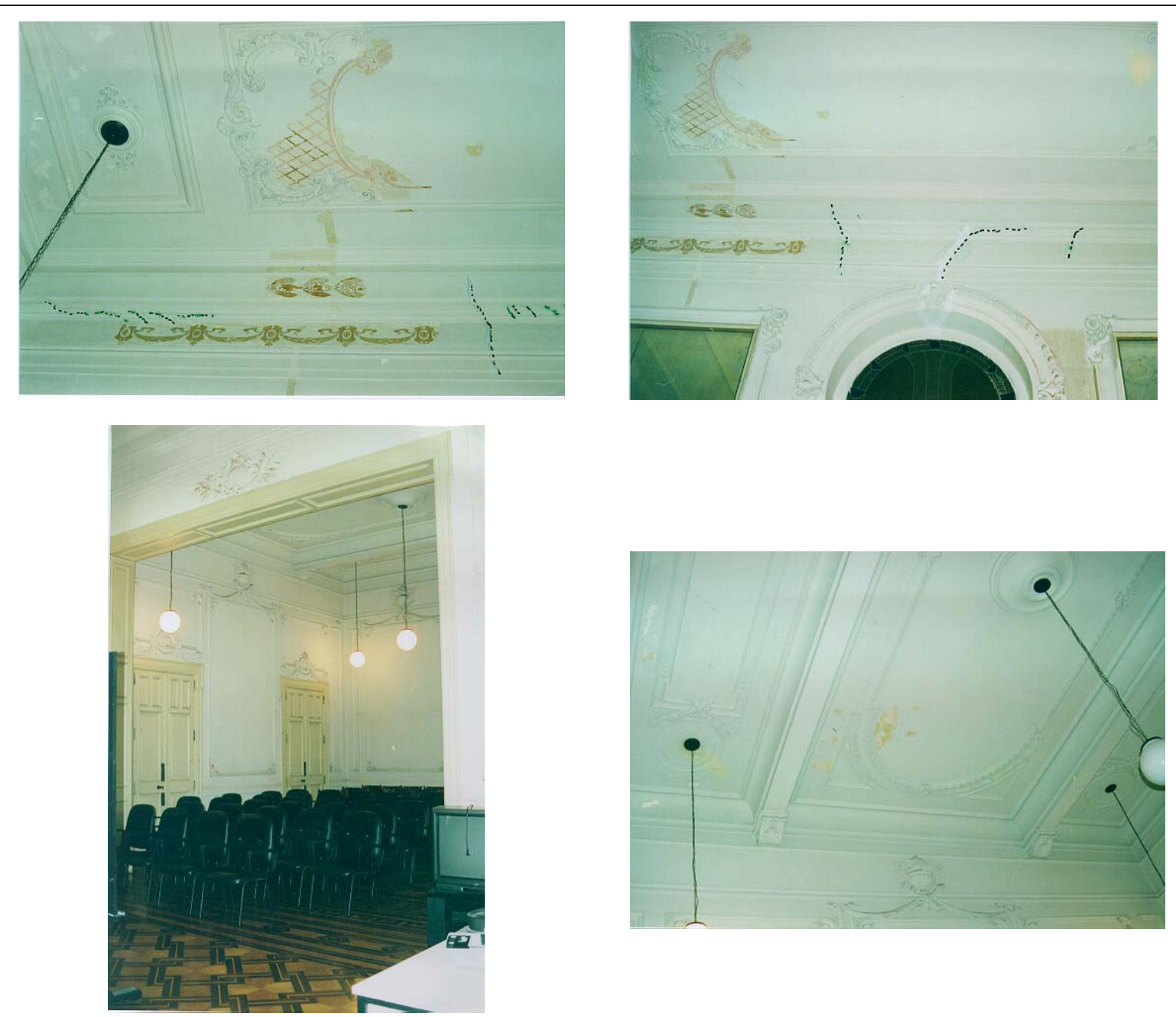

\section{T15}

Área: $94 \mathrm{~m}^{2}$

Tipo de forro: estuque

Estado de Conservação: Pouco fissurado Utilização: Auditório (2 ambientes) 


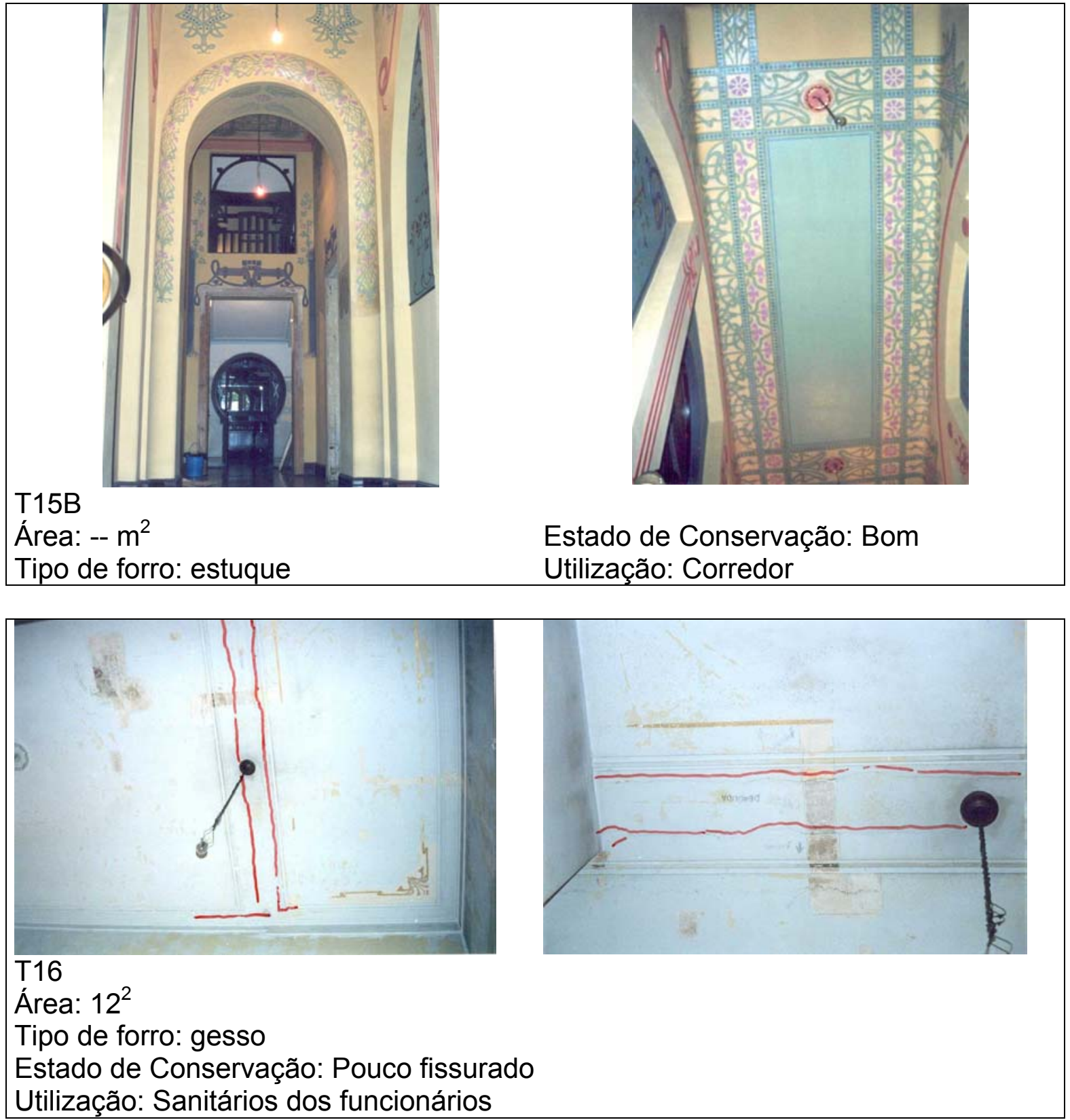

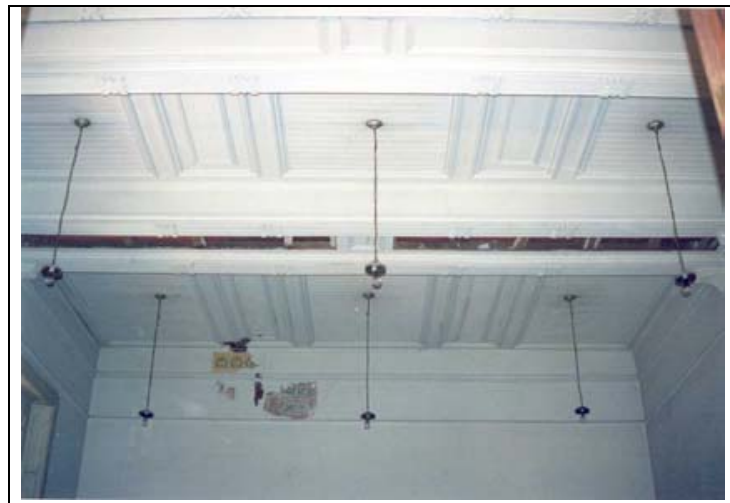

T17

Área: $66 \mathrm{~m}^{2}$

Tipo de forro: madeira

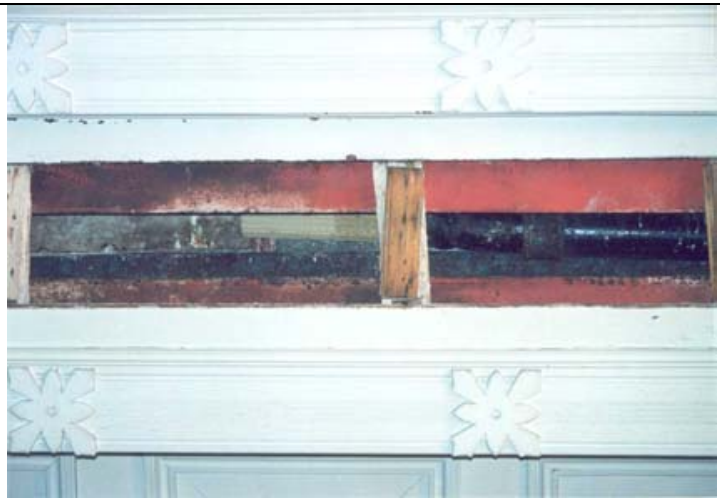

Estado de Conservação: Bom Utilização: Sala de aula 


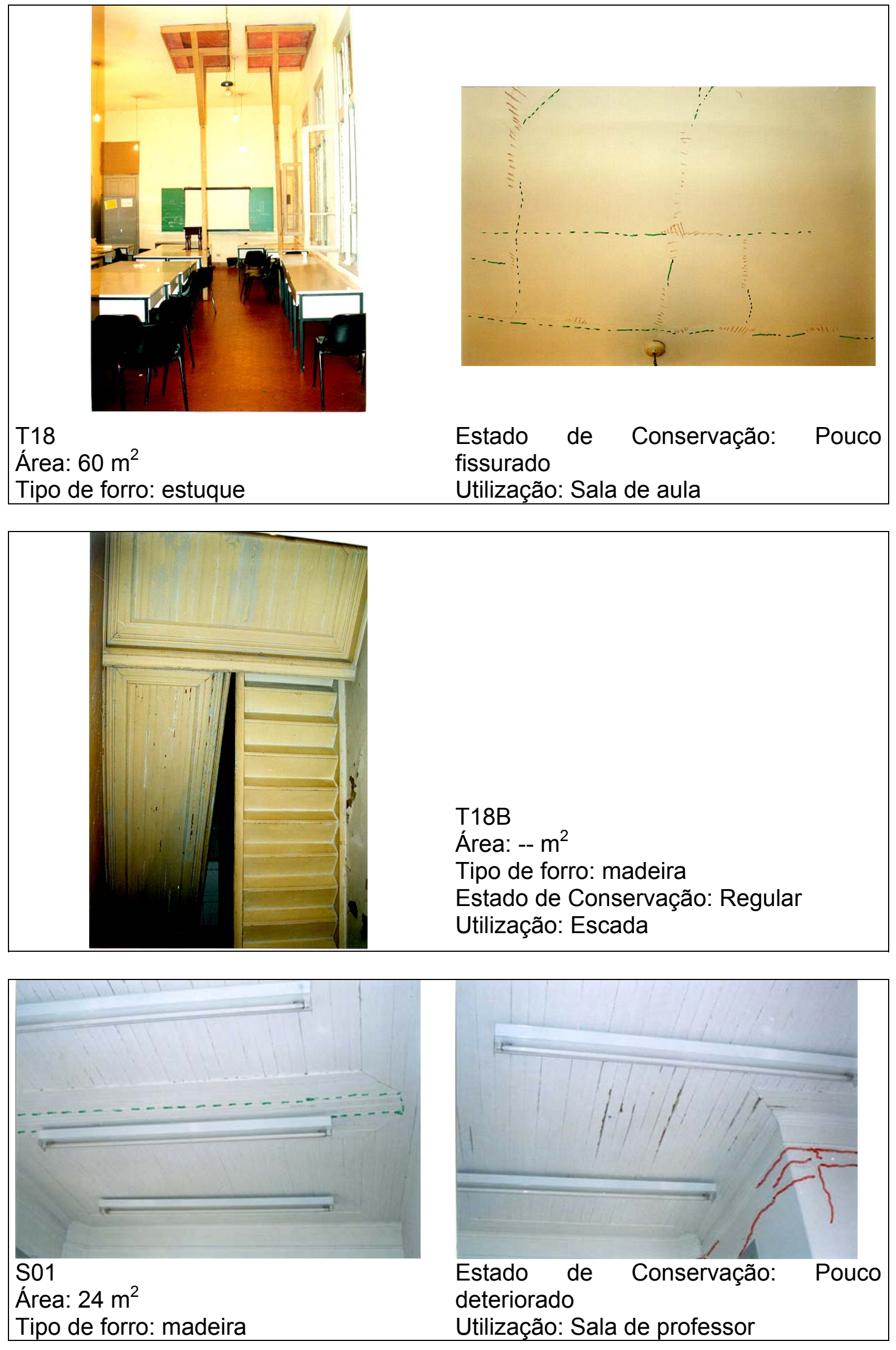



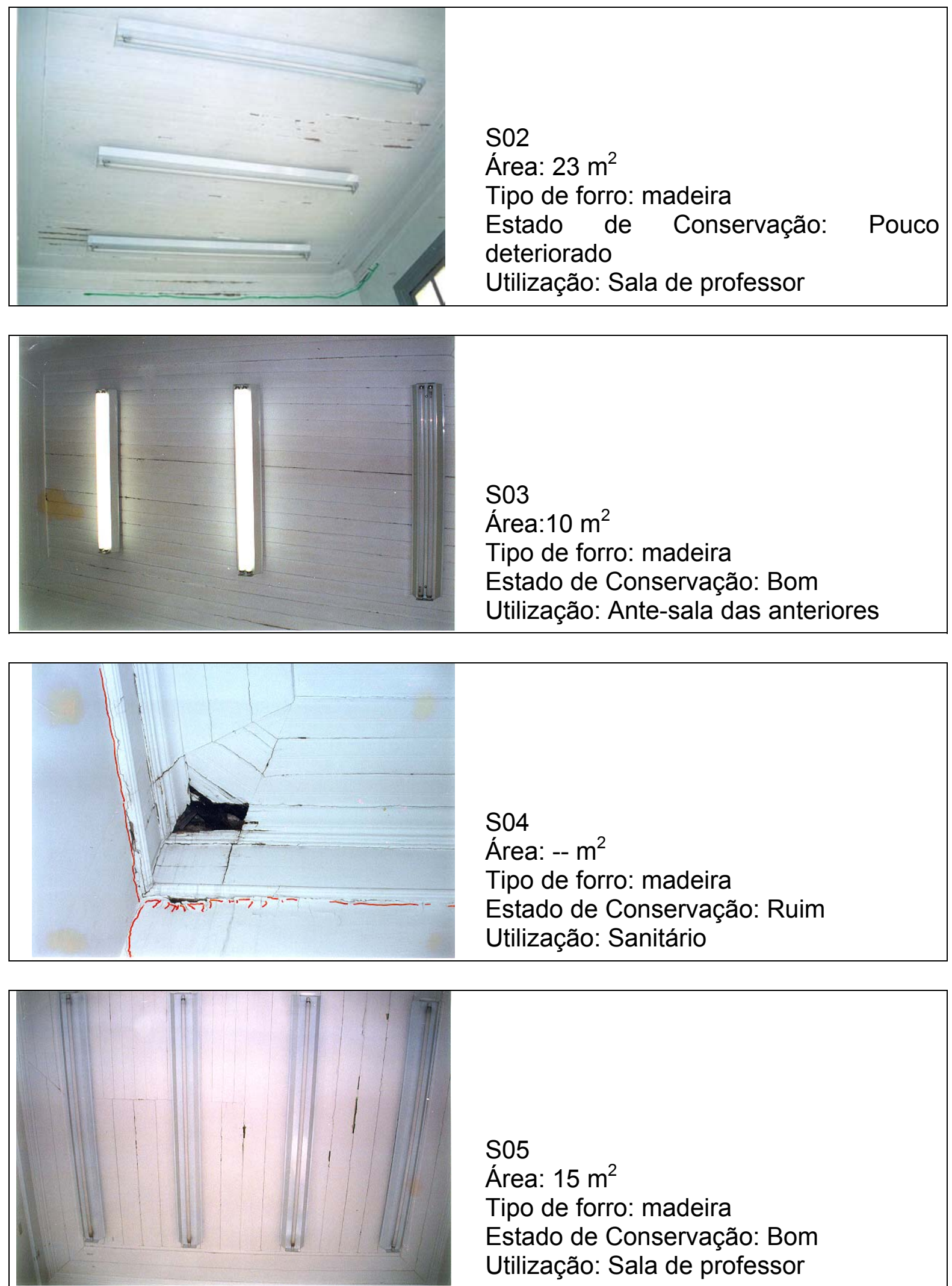

S05

Área: $15 \mathrm{~m}^{2}$

Tipo de forro: madeira

Estado de Conservação: Bom

Utilização: Sala de professor 

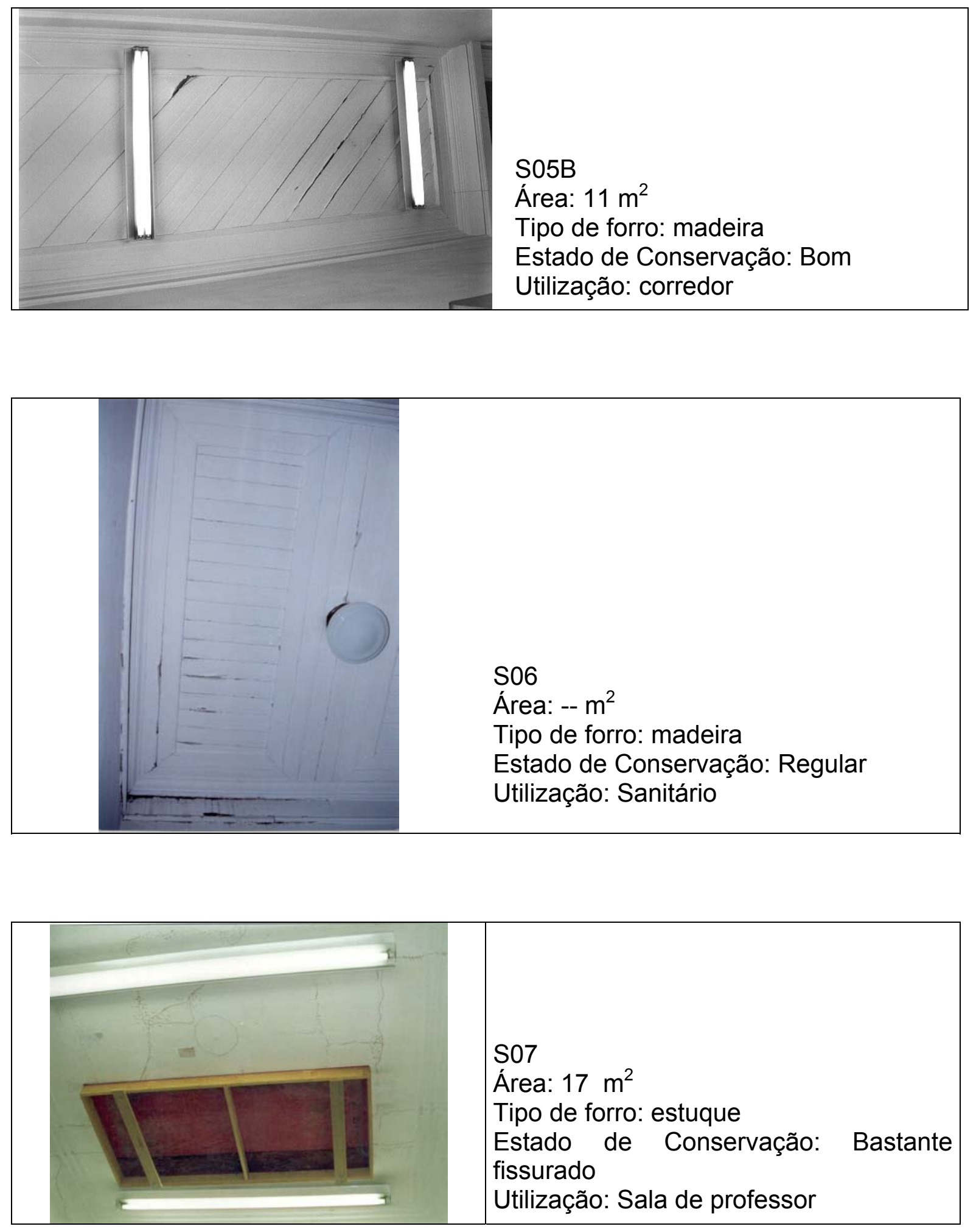

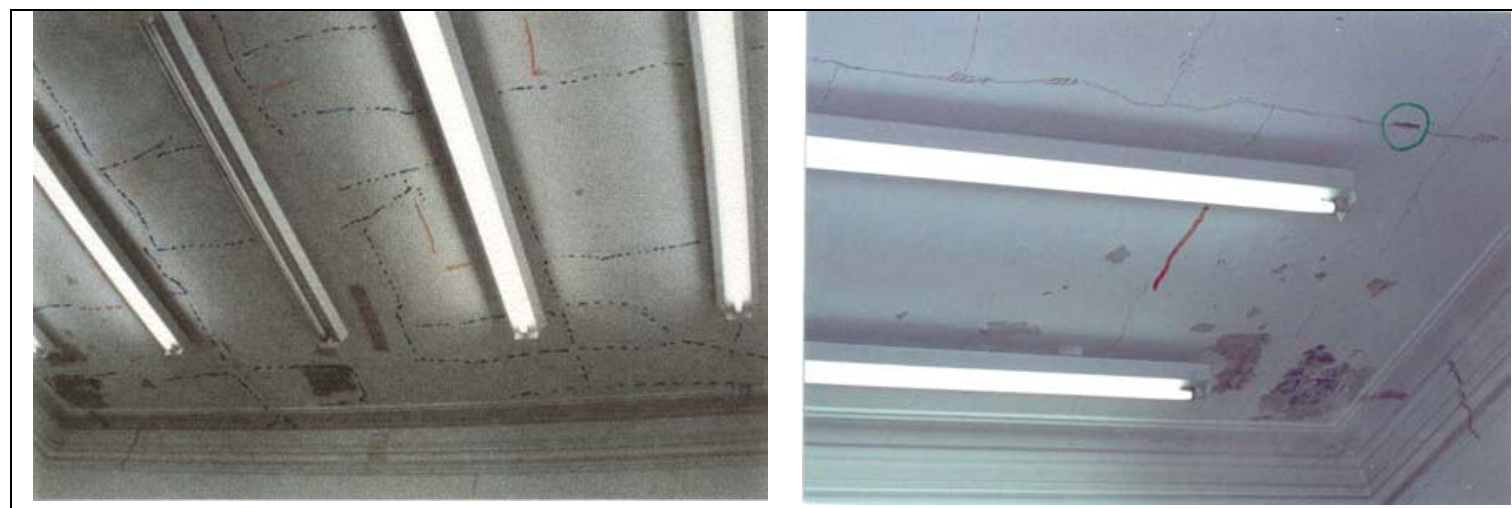

S09

Área: $30 \mathrm{~m}^{2}$

Tipo de forro: estuque

Estado de Conservação: Bastante fissurado

Utilização: Sala de professor

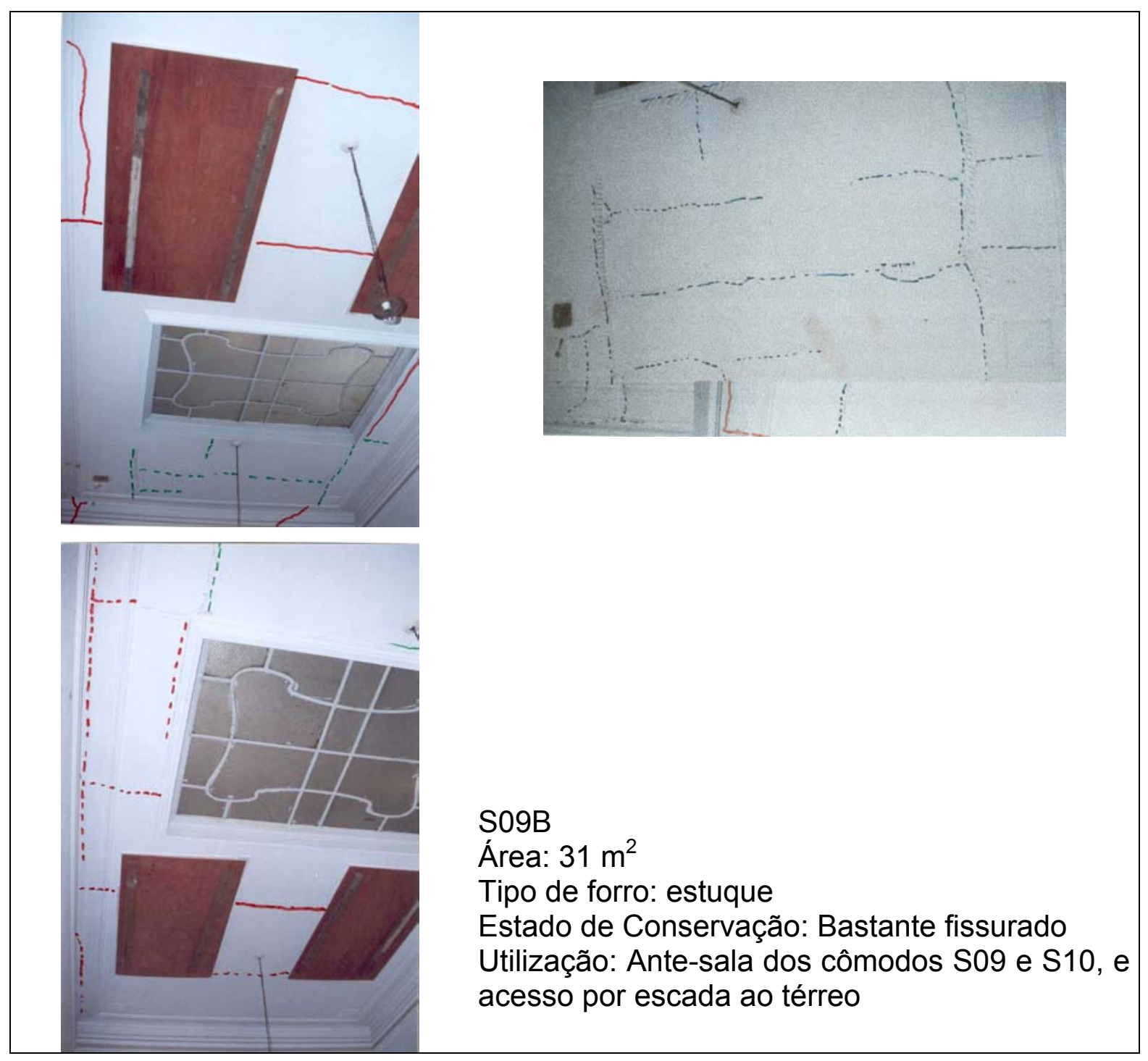



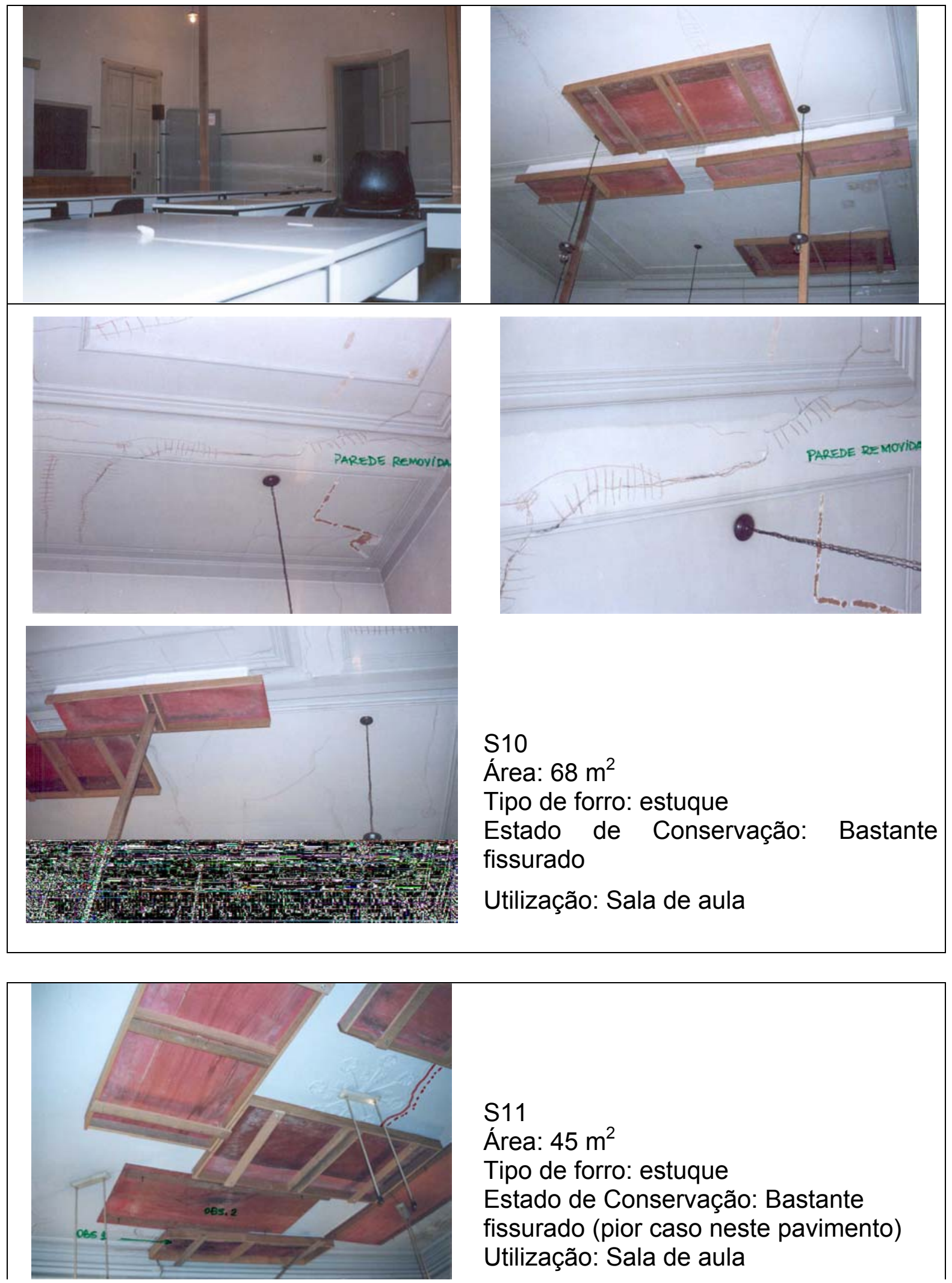

S11

Área: $45 \mathrm{~m}^{2}$

Tipo de forro: estuque

Estado de Conservação: Bastante fissurado (pior caso neste pavimento) Utilização: Sala de aula 

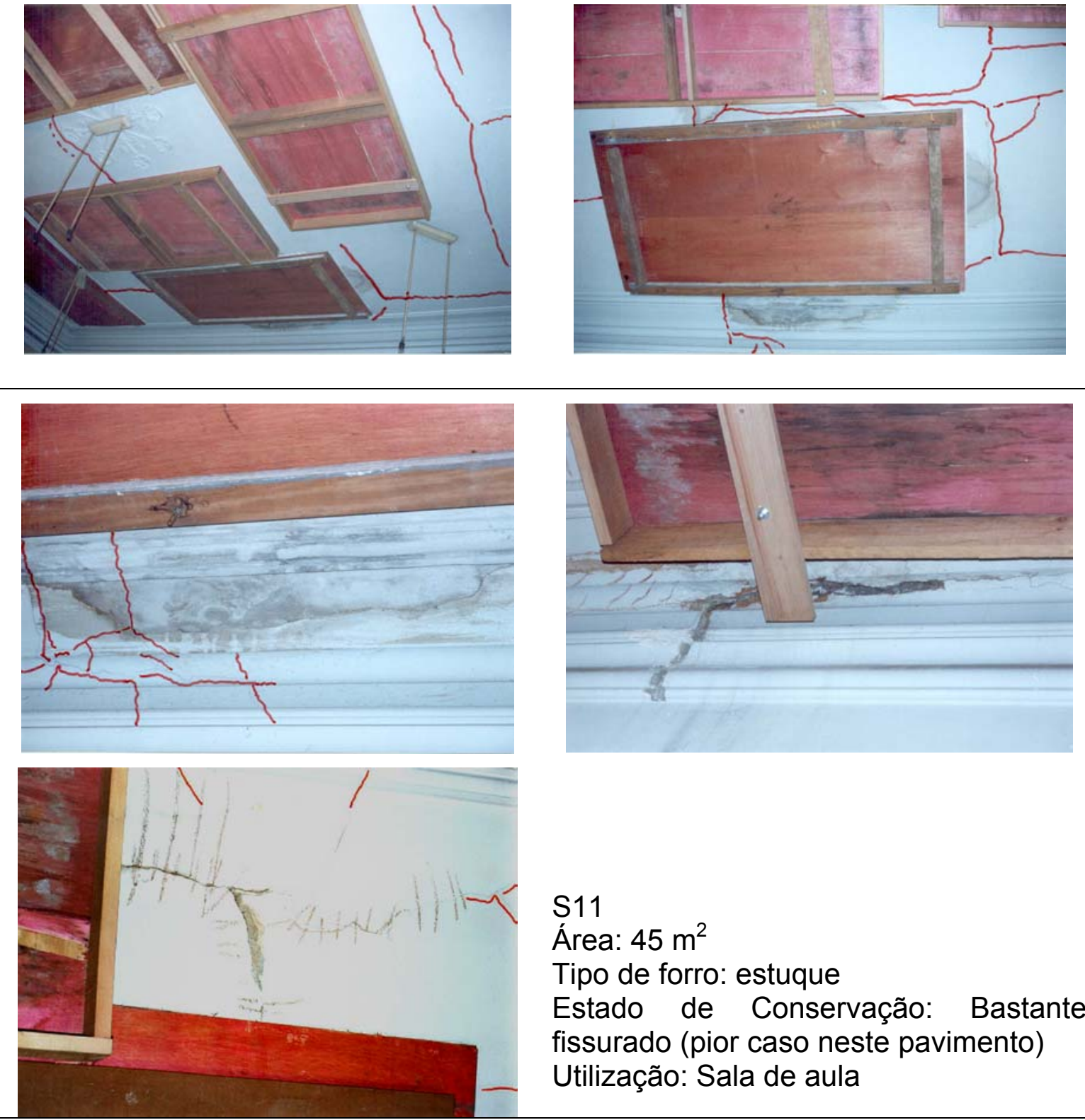

S11

Área: $45 \mathrm{~m}^{2}$

Tipo de forro: estuque

Estado de Conservação: Bastante fissurado (pior caso neste pavimento) Utilização: Sala de aula
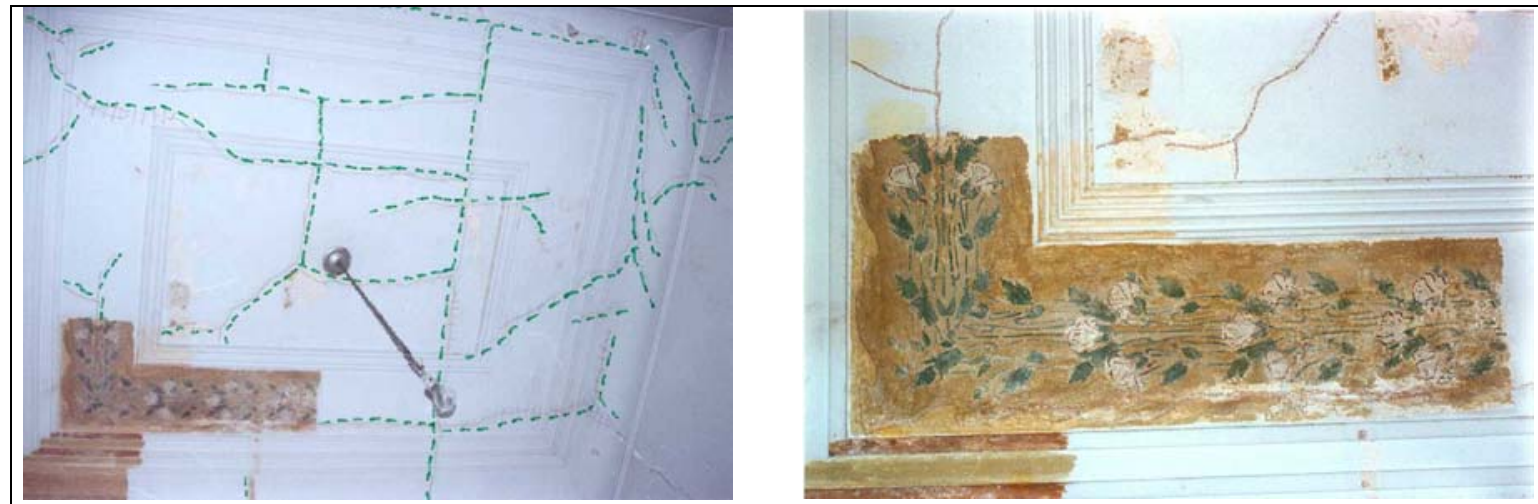

S11B

Área: $7 \mathrm{~m}^{2}$

Tipo de forro: estuque

Estado de Conservação: Bastante fissurado

Utilização: Ante-sala do cômodo S11 


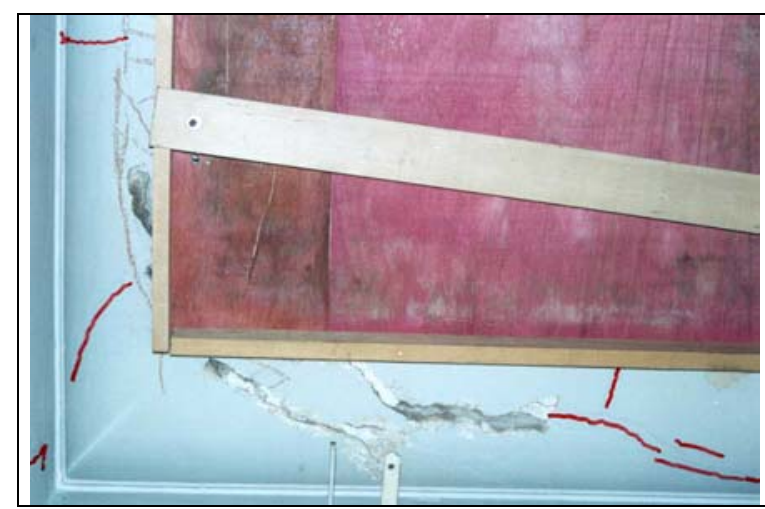

S12B

Área: $21 \mathrm{~m}^{2}$

Tipo de forro: estuque e madeira

Estado de Conservação: regular

Utilização: Ante-sala do cômodo S12

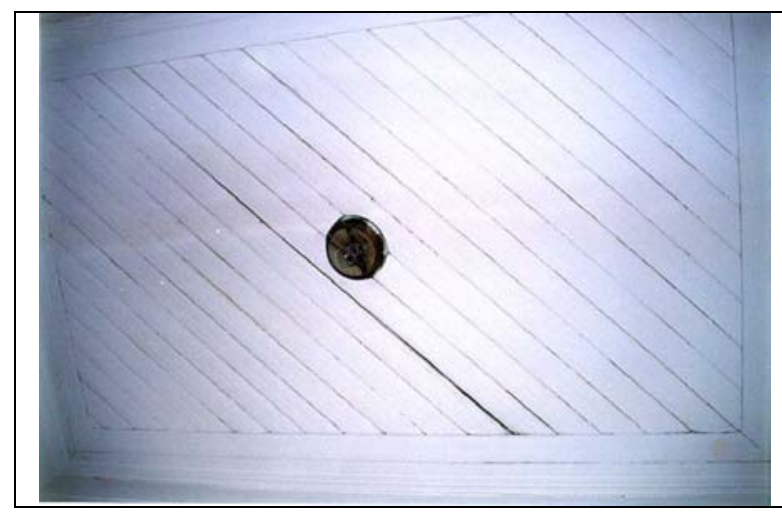

S13

Área: $4 \mathrm{~m}^{2}$

Tipo de forro: madeira

Estado de Conservação: Bom

Utilização: Sanitário

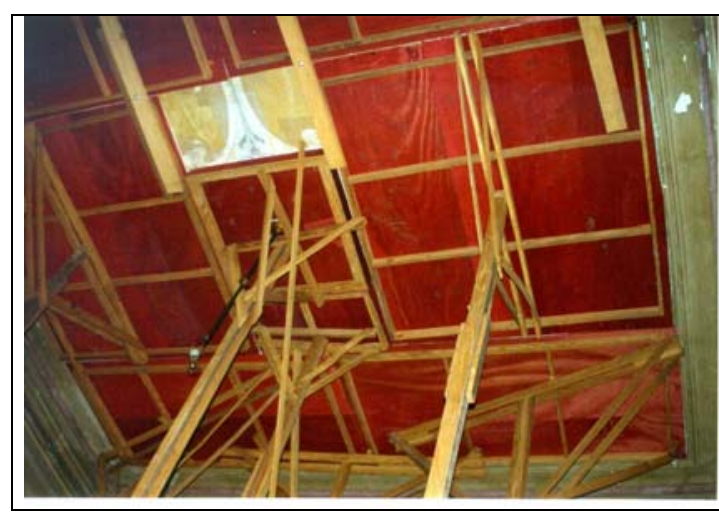

S14

Área: $23 \mathrm{~m}^{2}$

Tipo de forro: estuque

Estado de Conservação: completamente escorado

Utilização: Balcão do hall principal
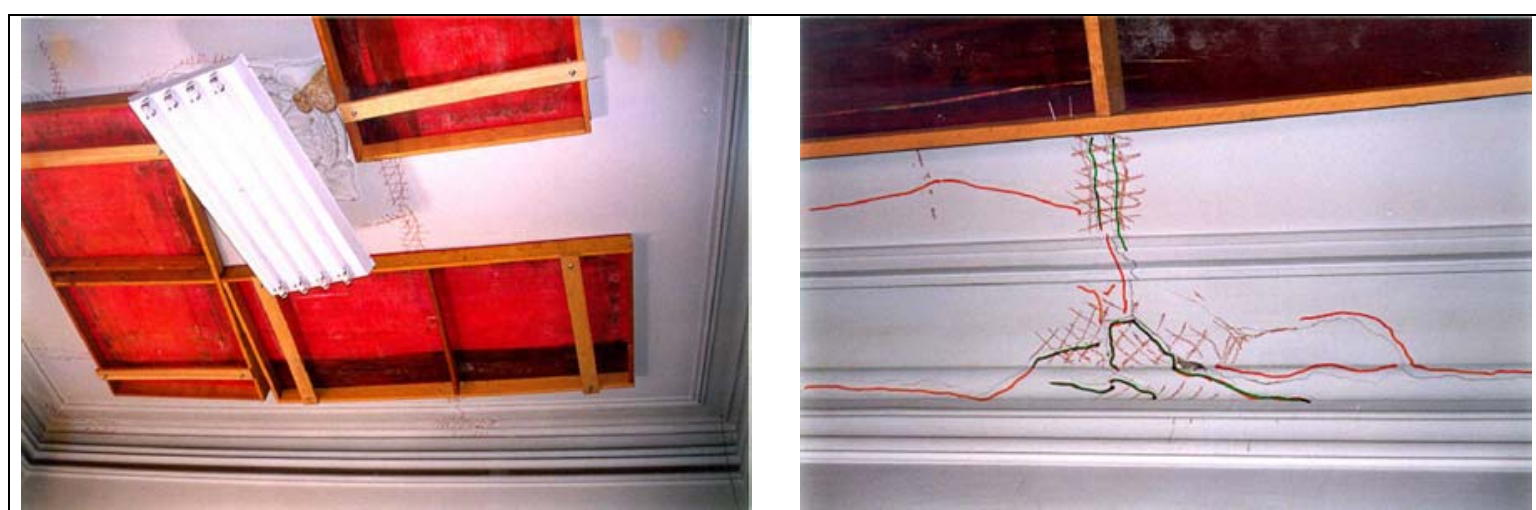

S17

Área: $23 \mathrm{~m}^{2}$

Tipo de forro: estuque

Estado de Conservação: Pouco fissurado

Utilização: Sala de professor 

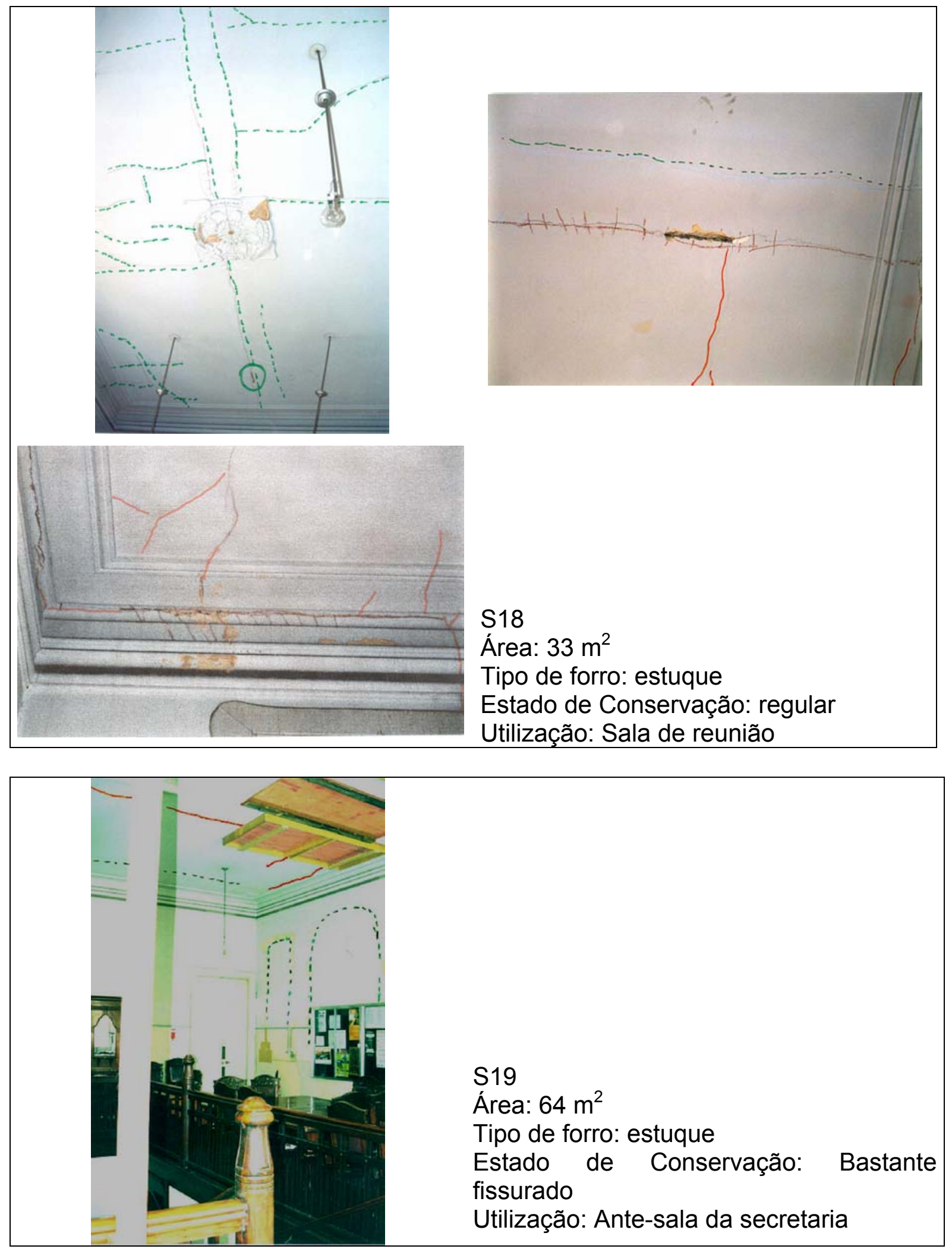

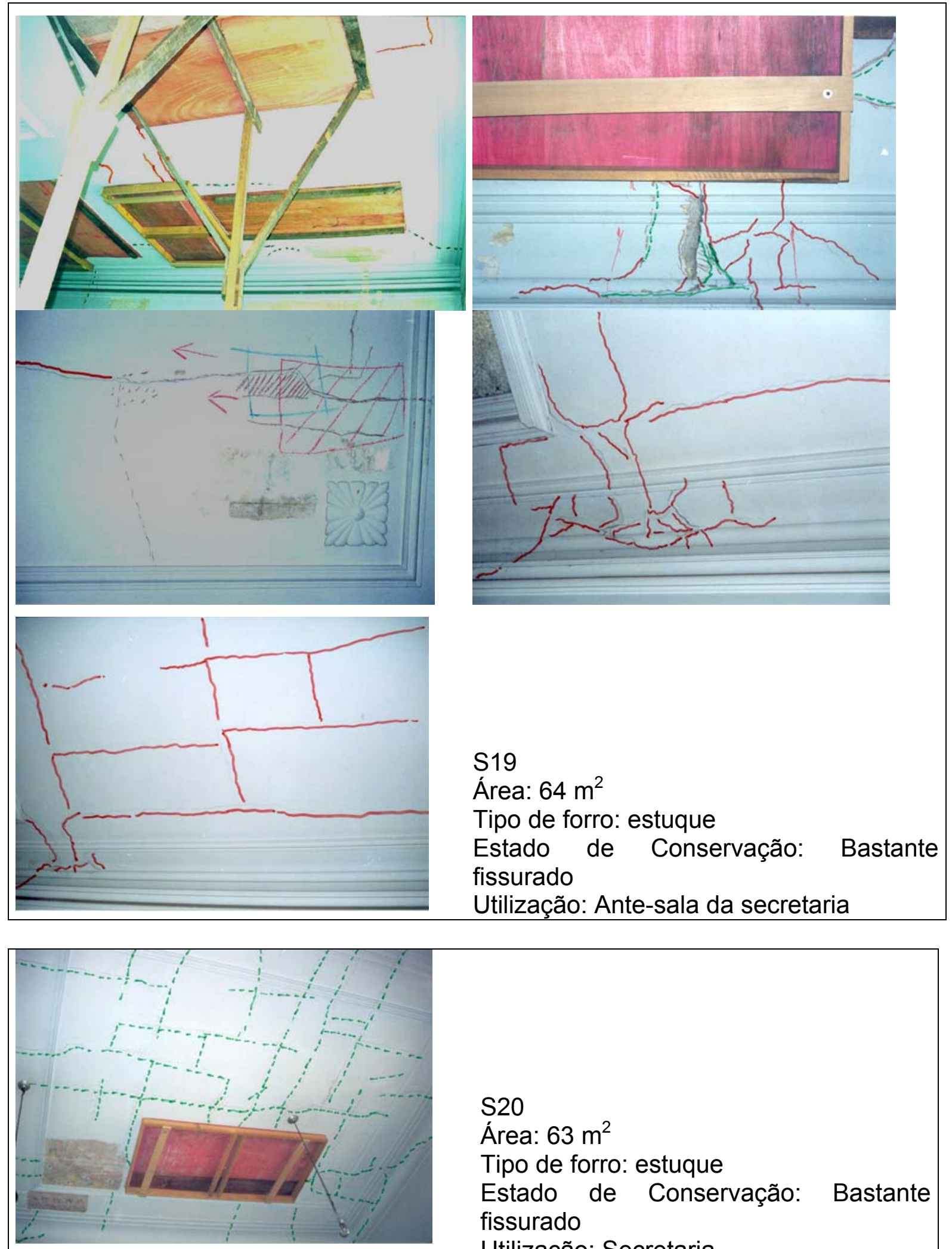

S20

Área: $63 \mathrm{~m}^{2}$

Tipo de forro: estuque

Estado de Conservação: Bastante fissurado 

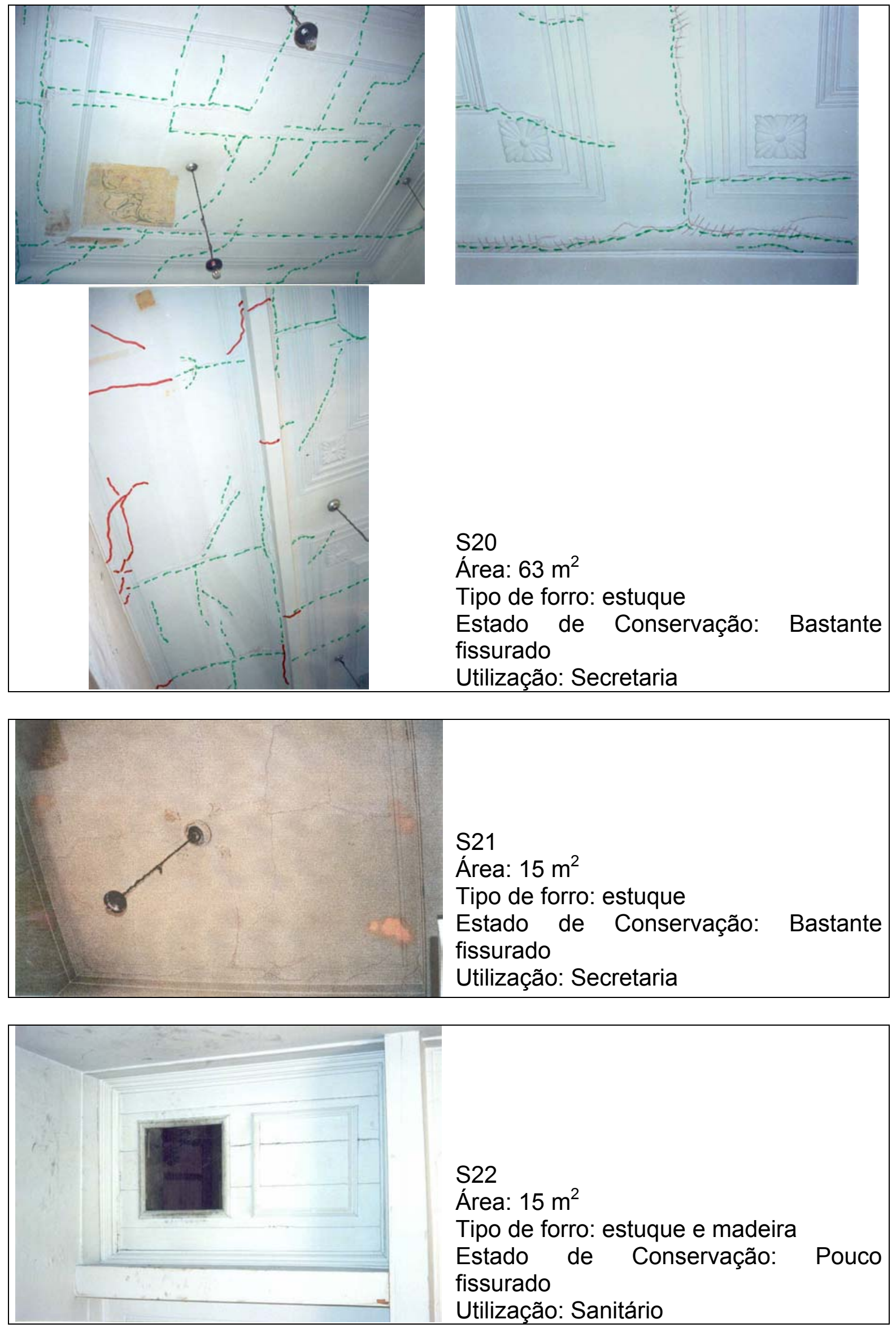

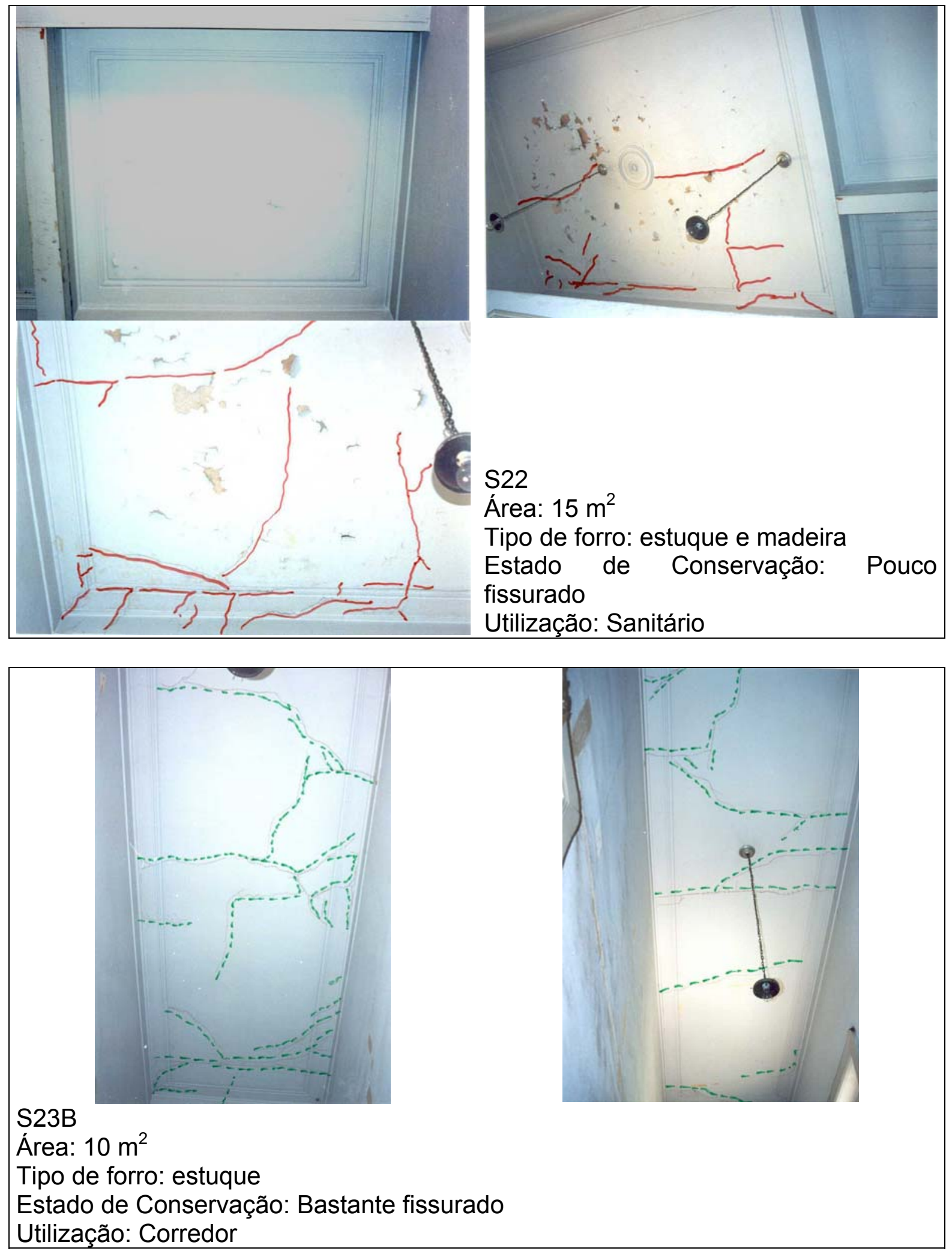

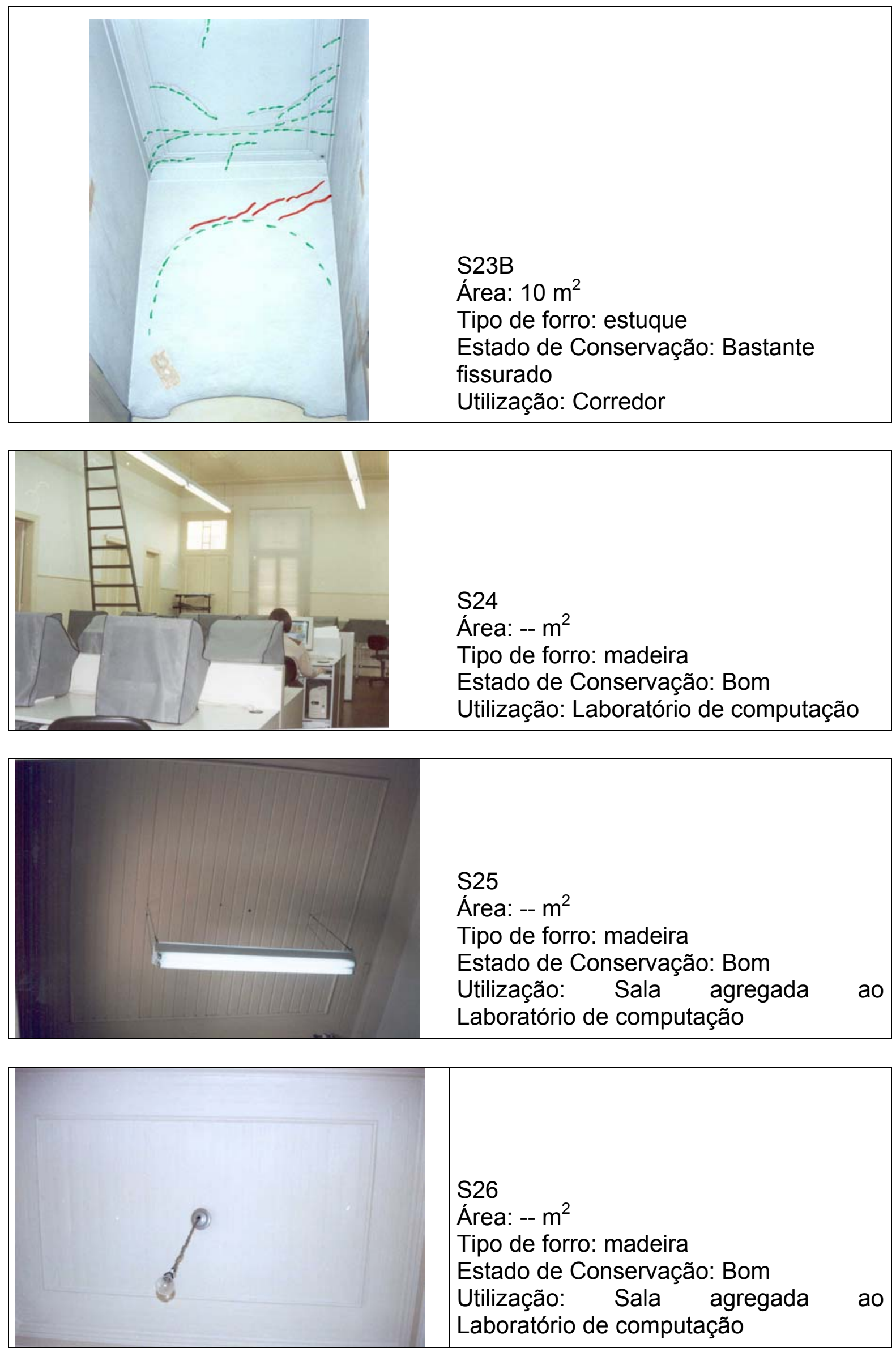


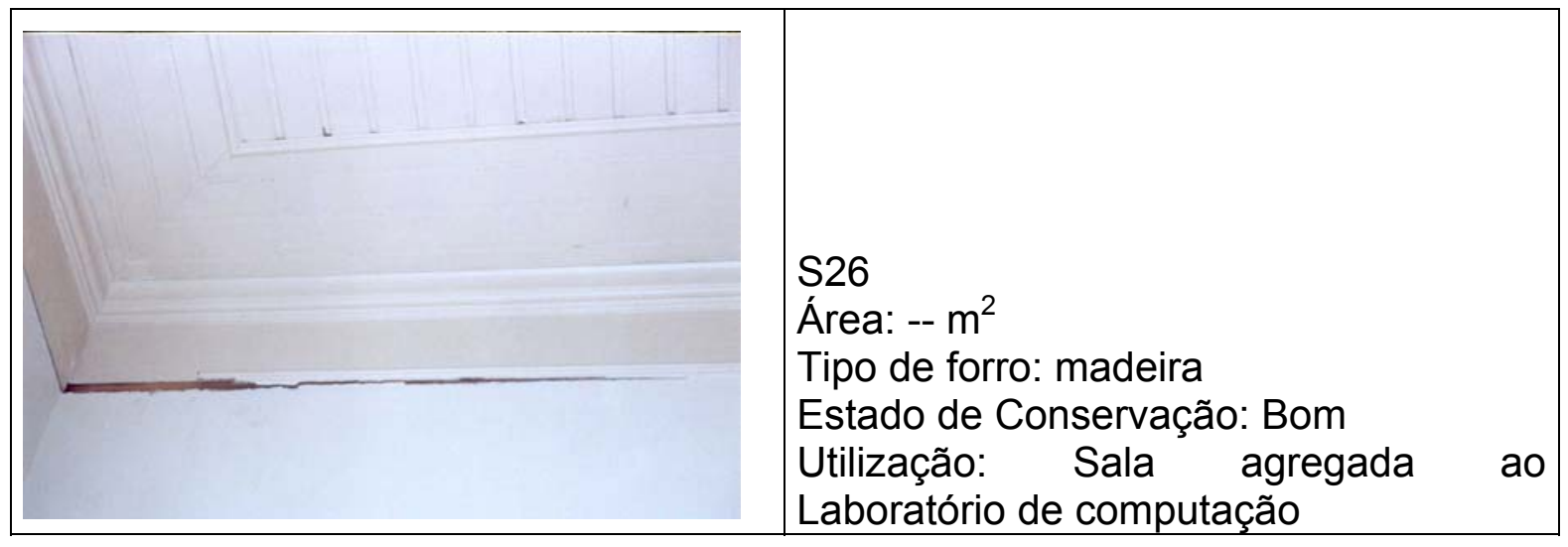




\section{ANEXO E - REGISTRO FOTOGRÁFICO DA MAPOTECA (T10) APÓS QUEDA PARCIAL DO FORRO EM 1994 (ARQUIVO FAUUSP)}

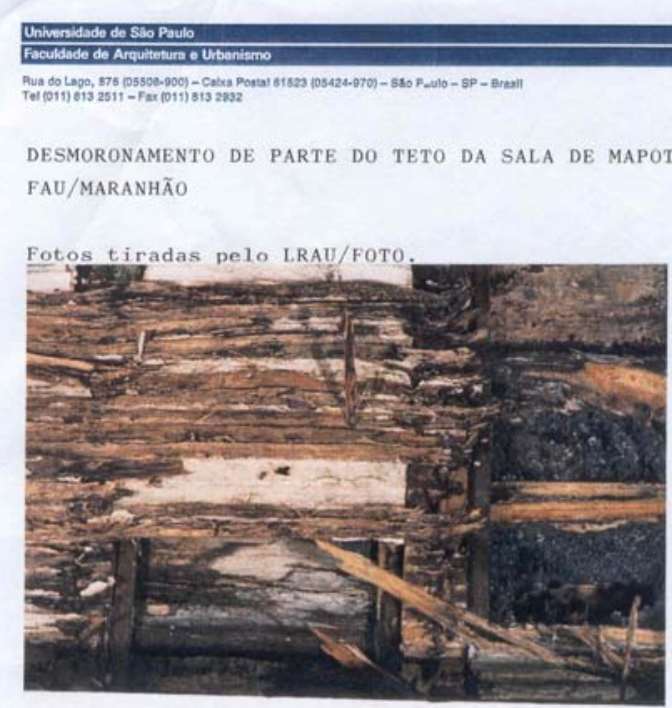

FOTO 1

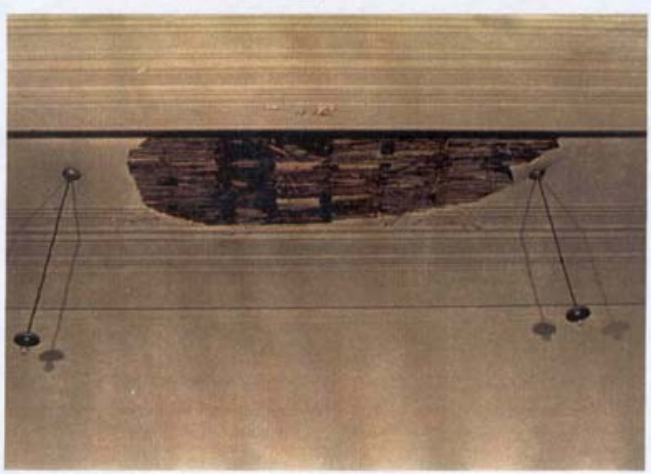

FОTO 2 
Anexo E - Registro fotográfico da mapoteca (T10) após queda parcial do forro em 1994 (arquivo FAUUSP)

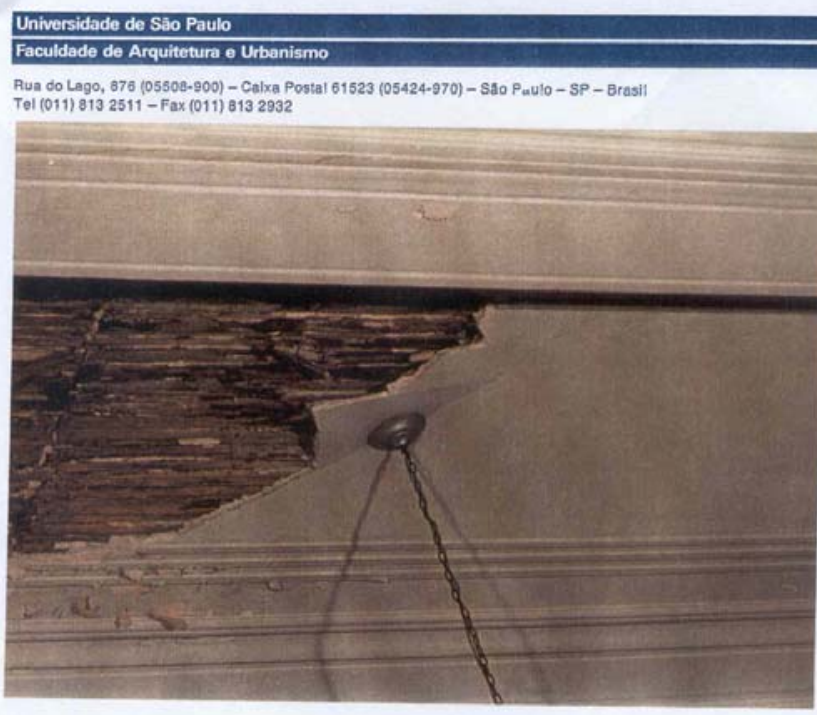

FOTO 3

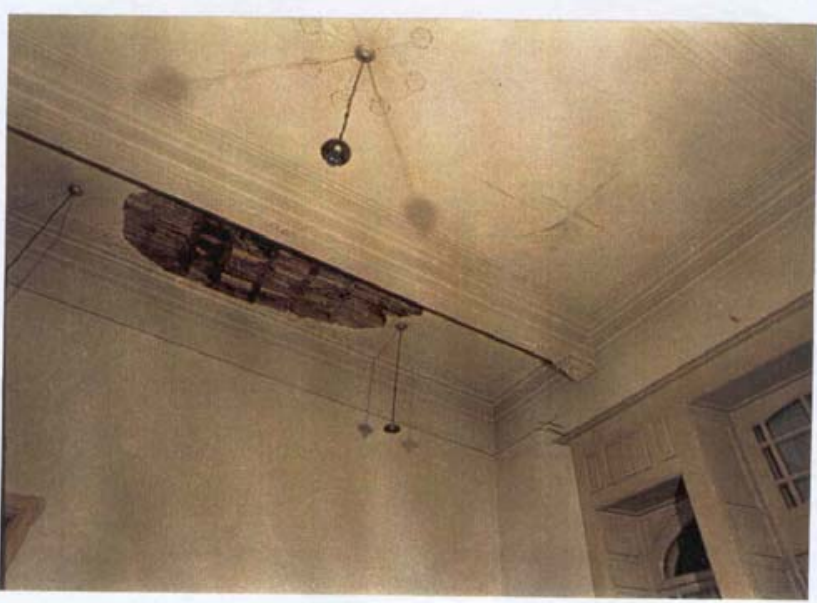

FOTO 4

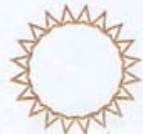


Anexo E - Registro fotográfico da mapoteca (T10) após queda parcial do forro em 1994 (arquivo FAUUSP)

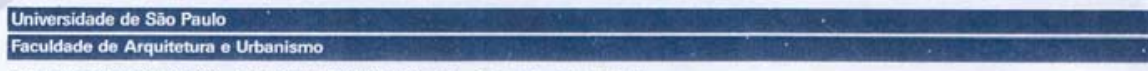

Aua do Lago, 878 (05508-900) - Caika Postal 61523 (05424-970) - SAO Paulo - SP - Bresil

Tel (011) 8132511 - Fax (011) 8132932

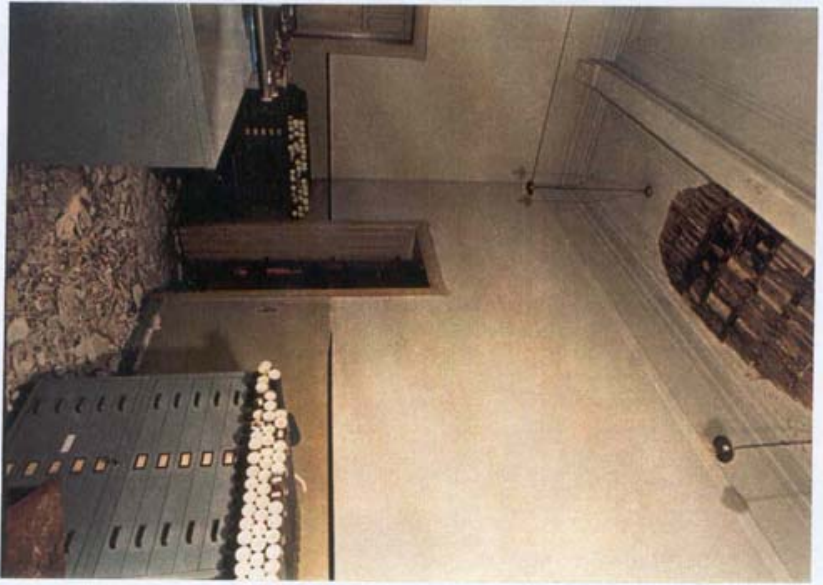

FOTO 5

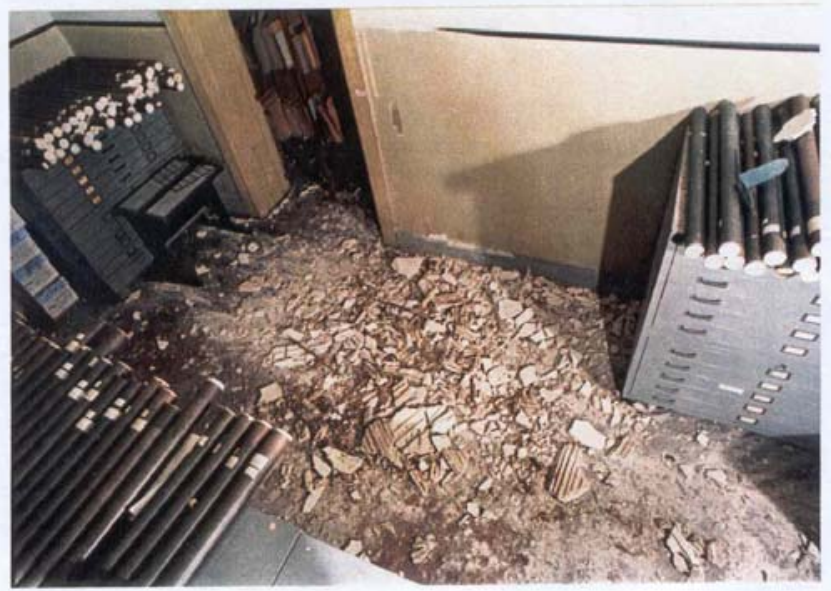

FOTO 6

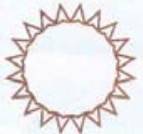


Anexo E - Registro fotográfico da mapoteca (T10) após queda parcial do forro em 1994 (arquivo FAUUSP)
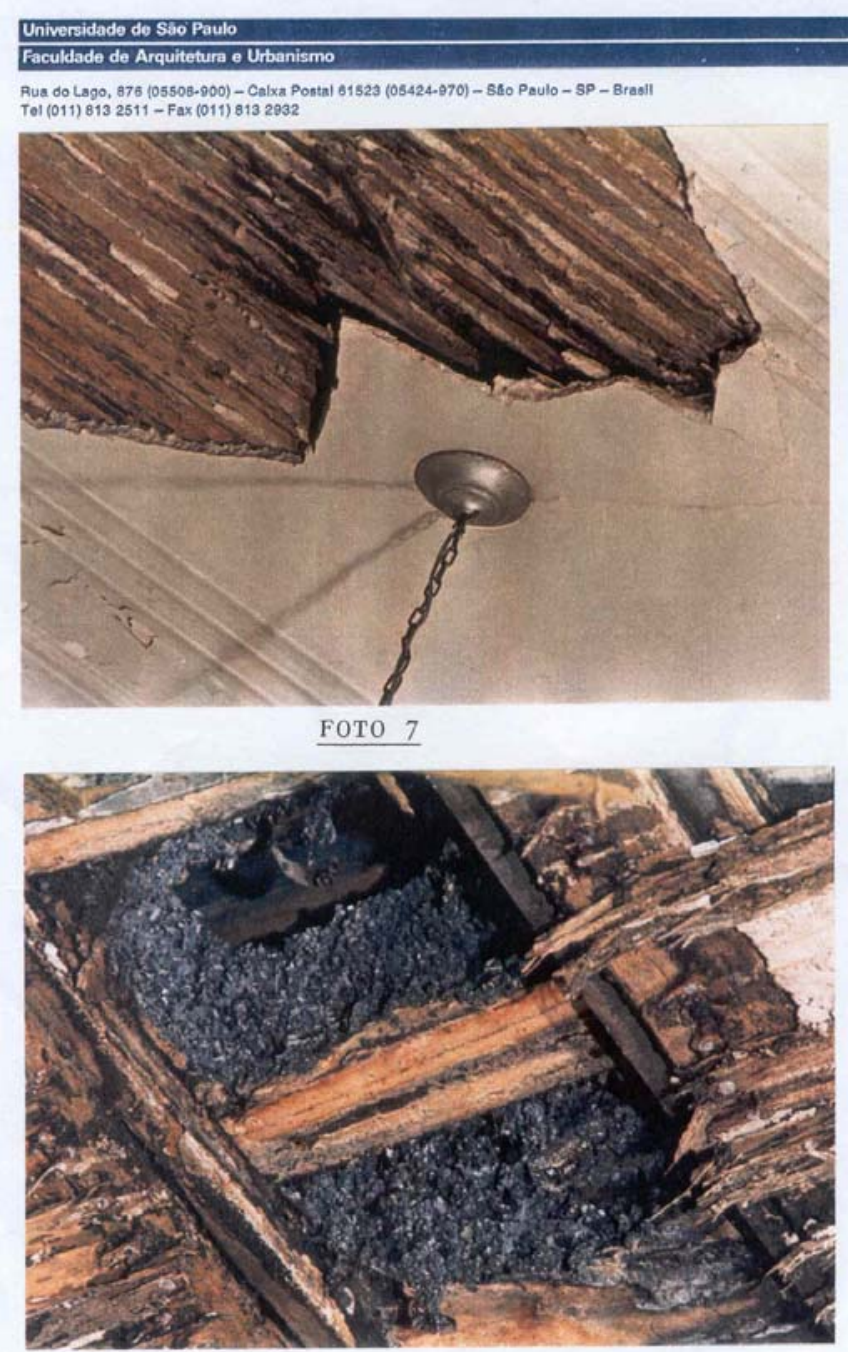

FOTO 8

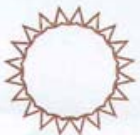


Anexo E - Registro fotográfico da mapoteca (T10) após queda parcial do forro em 1994 (arquivo FAUUSP)

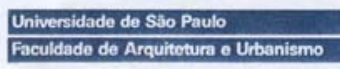

Rua do Lago, 876 (05508-900) - Calka Postal 81523 (05424-970) - SAo Paulo - SP - Brasli

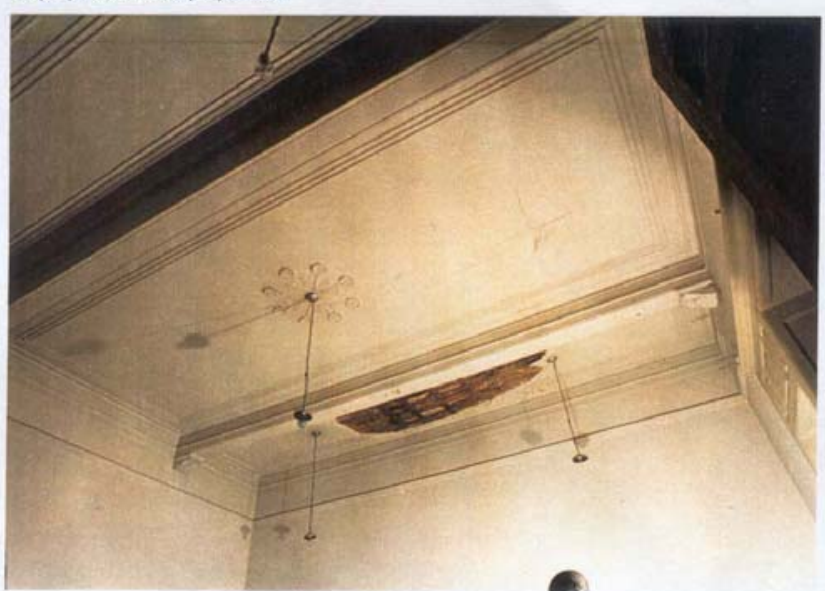

FOTO 9

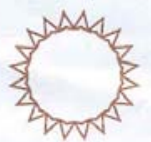




\section{ANEXO F - PROPOSTA DE FIXAÇÃO DO FORRO EM ESTUQUE PRECEDENTE A ESTE ESTUDO (ARQUIVO FAUUSP)}

A proposta discutida em reunião ocorrida em julho de 1997 da comissão técnica formada para avaliação e proposta de intervenção no forro da Vila Penteado. Formavam esta Comissão: Prof. Dr. Antônio Luiz Dias de Andrade (FAU), Art ${ }^{\mathrm{a}}$. Regina Tirello, (CPC Comissão do Patrimônio Cultural da USP), Arqt ${ }^{\mathrm{a}}$. Neide Ângela Joppert Cabral (Prefeitura da Universidade) e o Eng $^{\mathrm{o}}$ Fausto Tarran (FUNDUSP). Acompanharam os trabalhos da comissão Profs. Drs. Nestor Goulart Reis Filho, Gustavo Neves da Rocha Filho e Murillo Marx.

A proposta foi detalhada em 1999, posteriormente foi experimentada no pavimento superior, sem sucesso. O croqui da proposta de fixação do forro por meio de parafusos é apresentado na Figura F.1 e o procedimento apresentado posteriormente. 


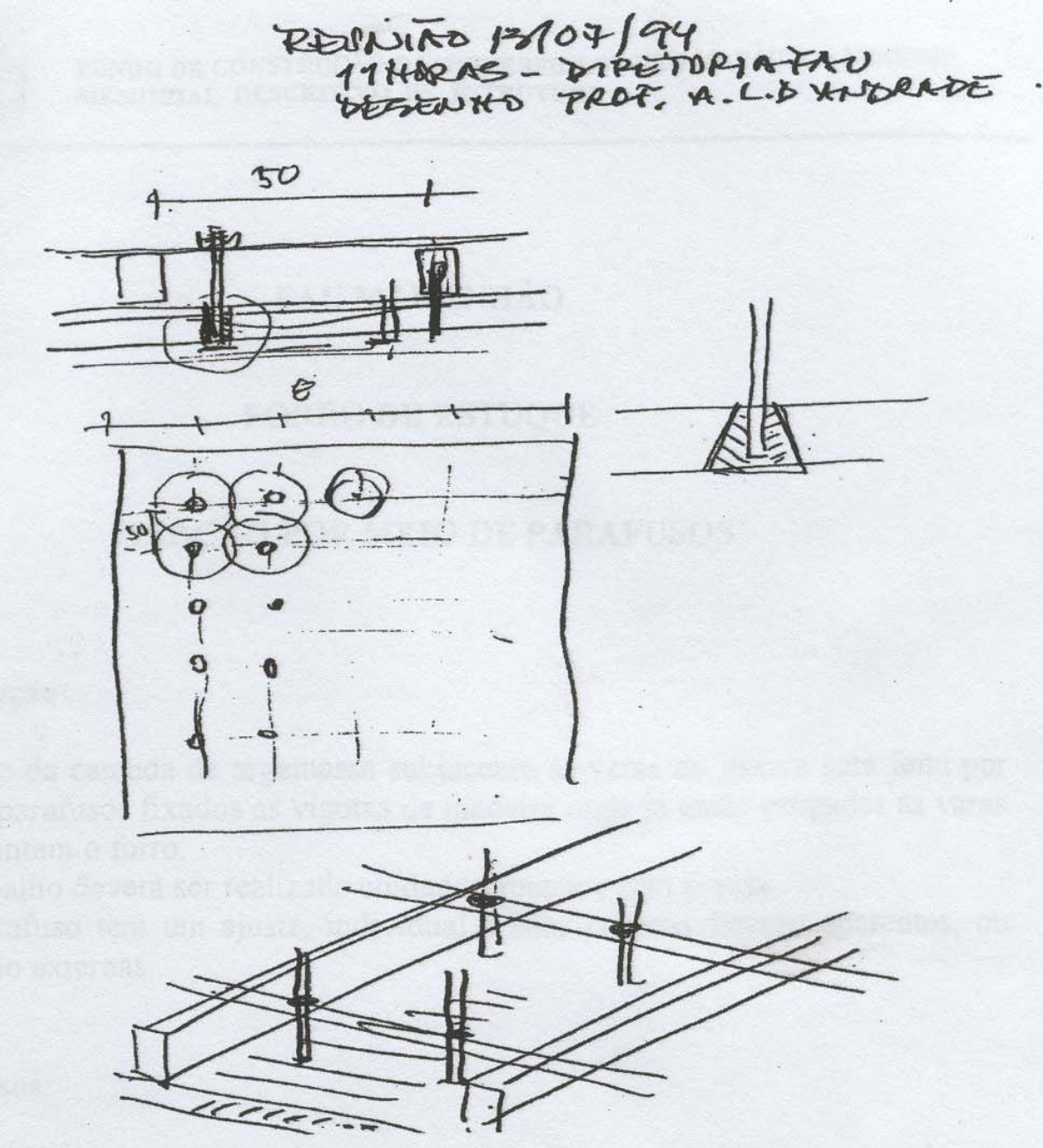

Figura F. 1 - Croqui da proposta de fixação do forro em estuque 
FAU MARANHĀO

FORRO DE ESTUQUE

FIXAÇĀO POR MEIO DE PARAFUSOS

\section{1 - Introdução}

A fixação da camada de argamassa subjacente às varas de jissara será feita por meio de parafusos fixados às vigotas de madeira onde já estão pregadas as varas que sustentam o forro.

Esse trabalho deverá ser realizado cuidadosamente e sem pressa.

Cada parafuso terá um ajuste, individual e suas cabeças ficarão aparentes, ou seja, serão externas.

\section{2 - Parafusos}

Os parafusos terăo comprimentos entre 55 e $60 \mathrm{~mm}$ (excluindo-se a cabeça); diâmetro entre 2,0 e $3,0 \mathrm{~mm}$, preferentemente $2,0 \mathrm{~mm}$; e a cabeça terá diâmetro minimo de $8 \mathrm{~mm}$ e será do tipo "cabeça de panela".

Diàmetros de cabeça com mais de $8 \mathrm{~mm}$ poderão ser inconvenientes do ponto de vista estético.

\section{$3-\underline{\text { Arruelas }}$}

O contato dos parafusos com a argamassa deverá ser feito por meio de arruelas. Duas soluções poderão ser utilizadas: arruelas de neoprene com diâmetro igual ao das cabeças dos parafusos e espessura com cerca de $0,5 \mathrm{~mm}$ ou resina epoxi ou poliester que será aplicada na região de contato entre as cabeças dos parafusus e a argamassa. 


\section{4 - Espacamento entre narafusos}

\subsection{Teto do pavimento térreo}

Observou-se que o espaçamento entre vigas de madeira, do forro do teto do pavimento térreo é de aproximadamente $50 \mathrm{~cm}$.

Assim, os parafusos serão colocados a cada $50 \mathrm{~cm}$, ao longo das vigas fazendo uma malha quadrada de $50 \mathrm{~cm} \times 50 \mathrm{~cm}$.

\subsection{Teto do pavimento superior}

No forro do pavimento superior o espaçamento entre vigas é de $45 \mathrm{~cm}$. A distância entre parafusos, ao longo dessas vigas, será de $50 \mathrm{~cm}$ fazendo uma malha retangular de $45 \mathrm{~cm} \times 50 \mathrm{~cm}$.

\section{5 - Eixos das Vigas}

Será necessário localizar os eixos das vigas de madeira. Essa localização será feita por tentativas utilizando-se broca de $2 \mathrm{~mm}$ de diâmetro para fazer furos expioratórios.

\section{6 - Furacão da argamassa}

A furação da argamassa será feita com ferramenta manual (furadeira manual). Será feito um furo piloto com broca para metais (aço rápido) de $2 \mathrm{~mm}$ de diâmetro. Esse furo piloto permitirá verificar se a passagem, até a viga de madeira, esta desobstruida (pode-se encontrar a cabeça de um prego no caminho) e se a espessura da camada de argamassa, sob a jissura, não está excessivamente fina (menor que $12 \mathrm{~mm}$ ).

Se se encontrar prego ou se a camada de argamassa for muito fina, despreza-se esse furo e abre-sc um outro $15 \mathrm{~mm}$ à esquerda ou à direita (sempre seguindo o eixo da viga de madeira)

Se a posição do orificio piloto for satisfatória, continua-se com a furação até que a broca penetre cerca $15 \mathrm{~mm}$ na madeira (o parafuso deverá penetrar pelo menos $10 \mathrm{~mm}$ na maderra) 

Alarga-se, a seguir, o orificio feito na argamassa para diâmetro igual ao do
parafuso.

Os furos deverão ser perpendiculares ao teto e deverão, ainda, desviar-se de altorelevos ou aplicaçōes existentes.

\section{7 - Colocacão dos narafusos}

7.1. Se for utilizada arruela, coloca-se o prafuso no orificio e faz-se com que o suficiente para dar uma pequena pressão na arruela.

7.2. Se for utilizada resina, no lugar de arruela, aplica-se pequena camada de resina na raparta-se o parafuso até que a resina toque na argamassa. impar, imediatamente, o excesso de resina. Esta resina poderá ser tipo massa plástica automotiva.

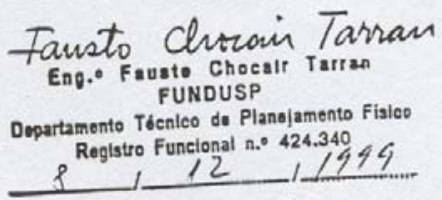

Fau-maranhũo mec 


\section{ANEXO G - RESULTADOS DAS ANÁLISES DE DRX}


Sample identification: PCC-CLAUDIA-T003X Data measured at: 11-Aug-1998 20:21:00

\author{
Diffractometer type: PW1710 BASED \\ Tube anode: $\mathrm{Cu}$ \\ Generator tension [kV]: 40 \\ Generator current $[\mathrm{mA}]: 50$ \\ Wavelength Alpha1 []: 1.54060 \\ Wavelength Alpha2 []: 1.54439 \\ Intensity ratio (alpha2/alpha1): 0.500 \\ Divergence slit: $1 / 2$ \\ Receiving slit: 0.2 \\ Spinner: ON \\ Monochromator used: YES
Start angle [ 2 ]: 2.500
End angle [ 2 ]: 80.000
Step size [ 2 ]: 0.020
Maximum intensity: 2851.560
Time per step [s]: 1.000
Type of scan: STEP
Minimum peak tip width: 0.05
Maximum peak tip width: 1.00
Peak base width: 2.00
Minimum significance: $\quad 0.75$
Number of peaks: 41

Angle d-value d-value Peak width Peak int Back. int Rel. int signif.

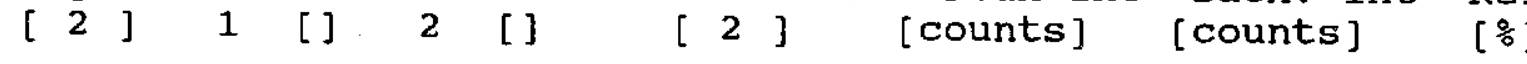

$\begin{array}{rrrrrr}10.920 & 8.0956 & 8.1155 & 0.480 & 10 & 15 \\ 12.455 & 7.1011 & 7.1185 & 0.240 & 13 & 13 \\ 18.545 & 4.7806 & 4.7924 & 0.120 & 72 & 11 \\ 20.905 & 4.2459 & 4.2564 & 0.120 & 807 & 13 \\ 23.065 & 3.8530 & 3.8624 & 0.160 & 21 & 14 \\ 23.660 & 3.7574 & 3.7666 & 0.160 & 15 & 14 \\ 24.945 & 3.5667 & 3.5755 & 0.160 & 31 & 15 \\ 25.665 & 3.4682 & 3.4768 & 0.160 & 36 & 16 \\ 26.695 & 3.3367 & 3.3449 & 0.140 & 2852 & 16 \\ 27.555 & 3.2345 & 3.2424 & 0.100 & 139 & 17 \\ 29.475 & 3.0280 & 3.0355 & 0.140 & 174 & 18 \\ 32.765 & 2.7311 & 2.7378 & 0.320 & 38 & 18 \\ 34.965 & 2.5641 & 2.5704 & 0.120 & 25 & 17 \\ 35.960 & 2.4954 & 2.5016 & 0.240 & 22 & 17 \\ 36.585 & 2.4542 & 2.4603 & 0.140 & 159 & 16 \\ 37.780 & 2.3793 & 2.3851 & 0.240 & 66 & 16 \\ 39.520 & 2.2784 & 2.2841 & 0.080 & 159 & 15 \\ 40.355 & 2.2332 & 2.2387 & 0.180 & 94 & 15 \\ 42.460 & 2.1272 & 2.1325 & 0.120 & 121 & 15 \\ 43.860 & 2.0625 & 2.0676 & 0.400 & 20 & 14 \\ 45.830 & 1.9783 & 1.9832 & 0.080 & 79 & 14 \\ 47.560 & 1.9103 & 1.9150 & 0.320 & 25 & 14 \\ 48.710 & 1.8679 & 1.8725 & 0.480 & 24 & 13\end{array}$

$\begin{array}{rr}0.3 & 1.19 \\ 0.5 & 0.98 \\ 2.5 & 1.90 \\ 28.3 & 11.87 \\ 0.7 & 0.80 \\ 0.5 & 0.99 \\ 1.1 & 1.08 \\ 1.3 & 1.25 \\ 100.0 & 26.63 \\ 4.9 & 1.71 \\ 6.1 & 2.29 \\ 1.3 & 1.74 \\ 0.9 & 1.85 \\ 0.8 & 1.06 \\ 5.6 & 4.34 \\ 2.3 & 4.10 \\ 5.6 & 1.22 \\ 3.3 & 4.37 \\ 4.2 & 2.73 \\ 0.7 & 1.15 \\ 2.8 & 0.75 \\ 0.9 & 0.90 \\ 0.8 & 2.20\end{array}$




\begin{tabular}{|c|c|c|c|c|c|c|c|}
\hline $\begin{array}{l}\text { Angle } \\
{\left[\begin{array}{ll} & 2\end{array}\right]}\end{array}$ & $\begin{array}{c}\text { d-value } \\
1\end{array}$ & $\begin{array}{l}\text { d-value } \\
2\end{array}$ & $\begin{array}{l}\text { Peak width } \\
{\left[\begin{array}{rl}2 & 2\end{array}\right]}\end{array}$ & $\begin{array}{l}\text { Peak int } \\
\text { [counts] }\end{array}$ & $\begin{array}{l}\text { Back. int } \\
\text { [counts] }\end{array}$ & $\begin{array}{l}\operatorname{Re} 1 \text {. int } \\
{[\%]}\end{array}$ & Signif. \\
\hline 0.145 & 1.8178 & 1.8222 & 0.120 & 313 & 13 & 11.0 & 5.14 \\
\hline 0.635 & 1.8013 & 1.8057 & 0.120 & 49 & 13 & 1.7 & 1.43 \\
\hline 4.900 & 1.6710 & 1.6751 & 0.100 & 77 & 15 & 2.7 & 0.89 \\
\hline 8.230 & 1.5831 & 1.5870 & 0.320 & 11 & 14 & 0.4 & 0.95 \\
\hline 9.960 & 1.5415 & 1.5453 & 0.100 & 213 & 15 & 7.5 & 2.43 \\
\hline 0.165 & 1.5368 & 1.5405 & 0.080 & 94 & 16 & 3.3 & 1.00 \\
\hline .010 & 1.4534 & 1.4570 & 0.160 & 55 & 12 & 1.9 & 1.74 \\
\hline 5.830 & 1.4176 & 1.4211 & 0.320 & 7 & 12 & 0.3 & 0.85 \\
\hline .725 & 1.3824 & 1.3858 & 0.100 & 108 & 12 & 3.8 & 1.77 \\
\hline .175 & 1.3744 & 1.3778 & 0.100 & 166 & 12 & 5.8 & 1.86 \\
\hline .340 & 1.3715 & 1.3749 & 0.080 & 177 & 12 & 6.2 & 1.11 \\
\hline 8.540 & 1.3680 & 1.3713 & 0.060 & 66 & 12 & 2.3 & 0.88 \\
\hline 1.680 & 1.3156 & 1.3188 & 0.480 & 4 & 11 & 0.1 & 1.27 \\
\hline .485 & 1.2877 & 1.2908 & 0.160 & 25 & 11 & 0.9 & 0.89 \\
\hline .700 & 1.2554 & 1.2585 & 0.120 & 59 & 10 & 2.1 & 2.23 \\
\hline 5.885 & 1.2528 & 1.2559 & 0.100 & 29 & 10 & 1.0 & 0.85 \\
\hline 7.640 & 1.2288 & 1.2318 & 0.160 & 20 & 10 & 0.7 & 0.84 \\
\hline .845 & 1.2003 & 1.2033 & 0.120 & 52 & 10 & 1.8 & 2.00 \\
\hline
\end{tabular}


Sample identification: PCC-CLAUDIA-TLOE

Data measured at: 11-Aug-1998 21:37:00

\author{
Diffractometer type: PW1710 BASED \\ Tube anode: $\mathrm{Cu}$ \\ Generator tension [kV]: 40 \\ Generator current $[\mathrm{mA}]: 50$ \\ Wavelength Alpha1 []: 1.54060 \\ Wavelength Alpha2 []: 1.54439 \\ Intensity ratio (alpha2/alpha1): 0.500 \\ Divergence slit: $1 / 2$ \\ Receiving slit: 0.2 \\ spinner: ON \\ Monochromator used: YES \\ Start angle [ 2 ] : 2.500 \\ End angle [ 2 ]: 80.000 \\ Step size [ 2 ]: 0.020 \\ Maximum intensity: 2970.250 \\ Time per step [s]: 1.000 \\ Type of scan: STEP \\ Minimum peak tip width: 0.05 \\ Maximum peak tip width: 1.00 \\ Peak base width: 2.00 \\ Minimum significance: 0.75 \\ Number of peaks: $\quad 35$
}

Angle d-value d-value Peak width Peak int Back. int Rel. int Signif. [ $\begin{array}{lll}2 & \text { ] }\end{array}$

$2[$ ]

[ 2 ] [counts] [counts]

$[\%]$

$\begin{array}{rrrrrr}13.795 & 6.4142 & 6.4299 & 0.240 & 6 & 10 \\ 20.930 & 4.2409 & 4.2514 & 0.140 & 729 & 10 \\ 23.125 & 3.8431 & 3.8526 & 0.240 & 17 & 11 \\ 24.945 & 3.5667 & 3.5755 & 0.320 & 8 & 11 \\ 25.670 & 3.4676 & 3.4761 & 0.240 & 24 & 12 \\ 26.730 & 3.3324 & 3.3406 & 0.160 & 2970 & 12 \\ 27.565 & 3.2333 & 3.2413 & 0.080 & 112 & 12 \\ 29.470 & 3.0285 & 3.0360 & 0.320 & 110 & 12 \\ 32.420 & 2.7594 & 2.7662 & 0.160 & 38 & 13 \\ 36.640 & 2.4507 & 2.4567 & 0.200 & 188 & 15 \\ 39.535 & 2.2776 & 2.2832 & 0.160 & 219 & 14 \\ 40.365 & 2.2327 & 2.2382 & 0.160 & 92 & 13 \\ 42.555 & 2.1227 & 2.1279 & 0.160 & 154 & 13 \\ 43.110 & 2.0967 & 2.1018 & 0.360 & 18 & 12 \\ 45.840 & 1.9779 & 1.9828 & 0.060 & 102 & 12 \\ 47.540 & 1.9111 & 1.9158 & 0.240 & 18 & 11 \\ 48.685 & 1.8688 & 1.8734 & 0.120 & 28 & 11 \\ 50.185 & 1.8164 & 1.8209 & 0.120 & 353 & 11 \\ 50.355 & 1.8107 & 1.8151 & 0.060 & 169 & 11 \\ 53.505 & 1.7113 & 1.7155 & 0.480 & 7 & 11 \\ 54.910 & 1.6707 & 1.6749 & 0.080 & 102 & 14\end{array}$

$\begin{array}{rr}0.2 & 0.86 \\ 24.5 & 13.43 \\ 0.6 & 1.04 \\ 0.3 & 0.88 \\ 0.8 & 1.92 \\ 100.0 & 34.78 \\ 3.8 & 1.12 \\ 3.7 & 8.37 \\ 1.3 & 1.08 \\ 6.3 & 10.95 \\ 7.4 & 5.88 \\ 3.1 & 3.97 \\ 5.2 & 4.75 \\ 0.6 & 1.59 \\ 3.4 & 1.89 \\ 0.6 & 0.99 \\ 0.9 & 1.09 \\ 11.9 & 4.54 \\ 5.7 & 1.72 \\ 0.2 & 1.21 \\ 3.4 & 1.13 \\ 1.4 & 0.96 \\ 0.5 & 1.36\end{array}$


File: PCCCT10 E

Angle d-value d-value Peak width Peak int Back. int Rel. int signif.

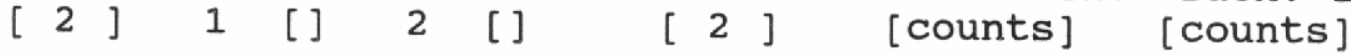
[\%]

$\begin{array}{rrrrr}59.965 & 1.5414 & 1.5452 & 0.140 & 210 \\ 60.190 & 1.5362 & 1.5400 & 0.060 & 117 \\ 64.080 & 1.4520 & 1.4556 & 0.080 & 52 \\ 65.810 & 1.4180 & 1.4214 & 0.160 & 12 \\ 67.745 & 1.3821 & 1.3855 & 0.120 & 128 \\ 68.195 & 1.3741 & 1.3774 & 0.060 & 202 \\ 68.350 & 1.3713 & 1.3747 & 0.080 & 196 \\ 73.480 & 1.2877 & 1.2909 & 0.160 & 44 \\ 73.735 & 1.2839 & 1.2871 & 0.060 & 34 \\ 75.695 & 1.2555 & 1.2585 & 0.140 & 92 \\ 75.915 & 1.2524 & 1.2554 & 0.100 & 55 \\ 77.700 & 1.2280 & 1.2310 & 0.100 & 32\end{array}$

13

13

11

11

11

11

11

10

10

8

8

8
7.1

3.9

1.7

0.4

4.3

6.8

6.6

1.5

1.1

3.1

1.8

1.1
4.51

1.76

0.83

0.81

2.56

1.77

1.11

1. 34

1. 24

3.76

1.19

0.77 
Sample identification: PCC-CLAUDIA-T10B

Data measured at: 23-Jul-1998 9:22:00

\author{
Diffractometer type: PW1710 BASED \\ Tube anode: $\mathrm{Cu}$ \\ Generator tension [kV]: 40 \\ Generator current [mA]: 40 \\ Wavelength Alpha1 []: 1.54060 \\ Wavelength Alpha2 []: 1.54439 \\ Intensity ratio (alpha2/alpha1): 0.500 \\ Divergence slit: 1 \\ Receiving slit: 0.2 \\ Spinner: ON \\ Monochromator used: YES \\ Start angle [ 2 ]: 2.500 \\ End angle [ 2 ]: 70.000 \\ Step size [ 2 ] : 0.020 \\ Maximum intensity: 2809.000 \\ Time per step [s]: 0.500 \\ Type of scan: STEP \\ Minimum peak tip width: 0.05 \\ Maximum peak tip width: 1.00 \\ Peak base width: 2.00 \\ Minimum significance: 0.75 \\ Number of peaks: 38
}

Angle d-value d-value Peak width Peak int Back. int Rel. int Signif.

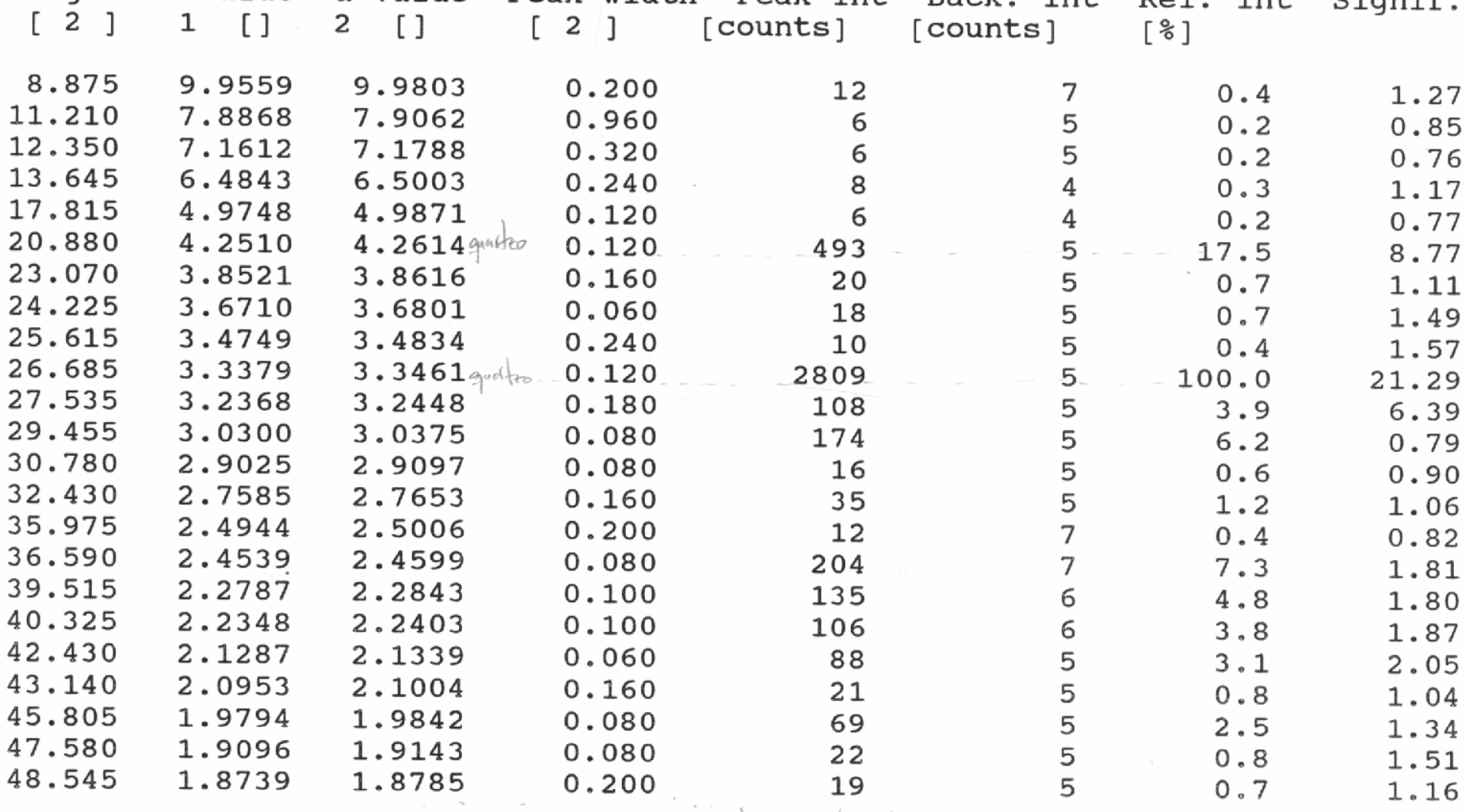


Angle d-value d-value Peak width Peak int Back. int Rel. int Signif. $\left[\begin{array}{lllllllll} & 2 & ] & 1 & {[} & 2 & \text { [ ] } & {\left[\begin{array}{ll}2 & \end{array}\right]} & \text { [counts] [counts] }\end{array}\right.$

$[\%]$

$\begin{array}{llllr}48.950 & 1.8593 & 1.8639 & 0.120 & 22 \\ 50.150 & 1.8176 & 1.8221 & 0.080 & 515 \\ 50.305 & 1.8123 & 1.8168 & 0.060 & 234 \\ 53.310 & 1.7171 & 1.7213 & 0.640 & 7 \\ 54.860 & 1.6721 & 1.6763 & 0.100 & 38 \\ 55.320 & 1.6593 & 1.6634 & 0.280 & 18 \\ 57.320 & 1.6061 & 1.6100 & 0.240 & 11 \\ 59.940 & 1.5420 & 1.5458 & 0.120 & 161 \\ 60.160 & 1.5369 & 1.5407 & 0.080 & 49 \\ 64.080 & 1.4520 & 1.4556 & 0.100 & 23 \\ 65.775 & 1.4186 & 1.4221 & 0.320 & 8 \\ 67.745 & 1.3821 & 1.3855 & 0.100 & 112 \\ 67.930 & 1.3788 & 1.3822 & 0.080 & 64 \\ 68.345 & 1.3714 & 1.3748 & 0.080 & 210 \\ 68.565 & 1.3675 & 1.3709 & 0.080 & 85\end{array}$

22

515

34

18

11

161

49

3

12

64

85

$\begin{array}{rr}0.8 & 1.19 \\ 18.3 & 3.41 \\ 8.3 & 0.82 \\ 0.2 & 1.47 \\ 1.4 & 1.50 \\ 0.7 & 3.02 \\ 0.4 & 2.15 \\ 5.7 & 4.07 \\ 1.7 & 1.20 \\ 0.8 & 0.88 \\ 0.3 & 1.00 \\ 4.0 & 2.54 \\ 2.3 & 0.81 \\ 7.5 & 1.27 \\ 3.0 & 1.40\end{array}$


Sample identification: PCC-CLAUDIA-T10D

Data measured at: 23-Jul-1998 9:59:00

\author{
Diffractometer type: PW1710 BASED \\ Tube anode: $\mathrm{Cu}$ \\ Generator tension [kV]: 40 \\ Generator current [mA]: 40 \\ Wavelength Alpha1 []: 1.54060 \\ Wavelength Alpha2 []: 1.54439 \\ Intensity ratio (alpha2/alpha1): 0.500 \\ Divergence slit: 1 \\ Receiving slit: 0.2 \\ Spinner: ON \\ Monochromator used: YES \\ Start angle [ 2 ] : 2.500 \\ End angle [ 2 ]: 70.000 \\ Step size [ 2 ]: 0.020 \\ Maximum intensity: 2401.000 \\ Time per step [s]: 0.500 \\ Type of scan: STEP \\ Minimum peak tip width: 0.05 \\ Maximum peak tip width: 1.00 \\ Peak base width: 2.00 \\ Minimum significance: 0.75 \\ Number of peaks: 37
}

Angle d-value d-value Peak width Peak int Back. int Rel. int Signif.

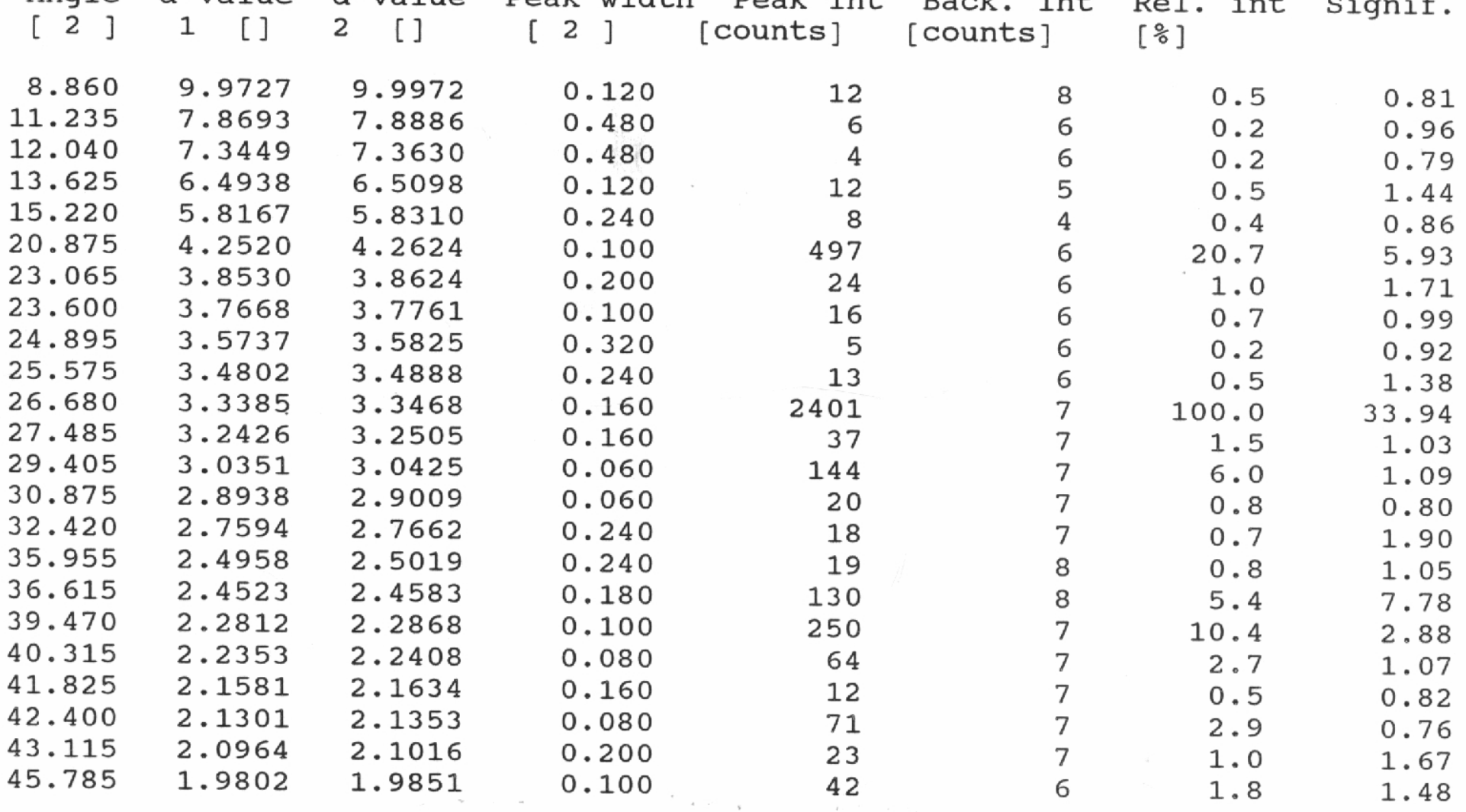




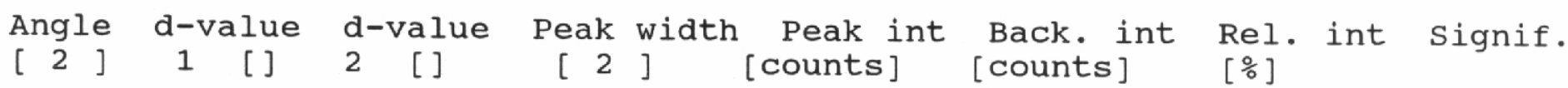

$\begin{array}{llllr}47.565 & 1.9102 & 1.9149 & 0.240 & 22 \\ 48.490 & 1.8759 & 1.8805 & 0.240 & 27 \\ 50.105 & 1.8191 & 1.8236 & 0.120 & 204 \\ 53.365 & 1.7154 & 1.7196 & 0.640 & 4 \\ 54.840 & 1.6727 & 1.6768 & 0.060 & 64 \\ 55.295 & 1.6600 & 1.6641 & 0.120 & 27 \\ 57.345 & 1.6055 & 1.6094 & 0.240 & 9 \\ 59.960 & 1.5415 & 1.5453 & 0.100 & 161 \\ 60.145 & 1.5372 & 1.5410 & 0.100 & 61 \\ 64.020 & 1.4532 & 1.4568 & 0.060 & 30 \\ 64.200 & 1.4496 & 1.4531 & 0.060 & 18 \\ 65.780 & 1.4185 & 1.4220 & 0.160 & 18 \\ 67.715 & 1.3826 & 1.3860 & 0.080 & 58 \\ 68.195 & 1.3741 & 1.3774 & 0.120 & 117\end{array}$

0.9

2.14

1.1

2.04

8.5

4.68

0.2

0.95

2.7

2.08

$1.1 \quad 1.82$

$0.4 \quad 1.26$

$6.7 \quad 3.00$

$2.5 \quad 0.83$

$1.3 \quad 1.94$

$0.7 \quad 0.85$

$0.8 \quad 0.91$

$2.4 \quad 1.70$

$4.9 \quad 1.80$ 
Sample identification: PCC-CLAUDIA-T10X-P

Data measured at: 12-Aug-1998 0:08:00

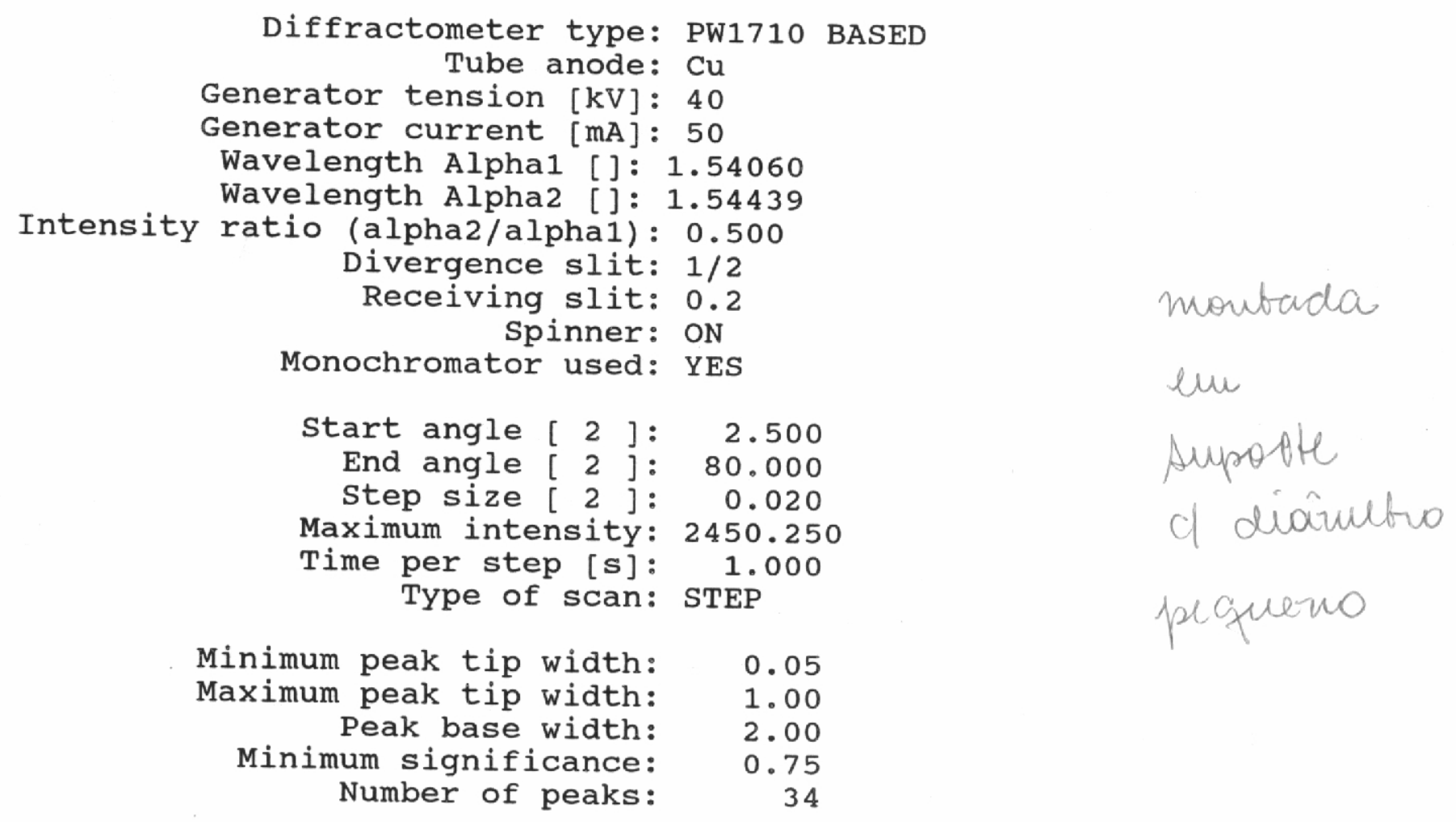

Angle d-value d-value

$\begin{array}{cc}{[2]} & 1 \\ 15.225 & 5.8148 \\ 18.395 & 4.8193 \\ 20.930 & 4.2409 \\ 23.130 & 3.8423 \\ 25.730 & 3.4596 \\ 26.720 & 3.3336 \\ 27.590 & 3.2305 \\ 29.510 & 3.0245 \\ 32.460 & 2.7561 \\ 35.990 & 2.4934 \\ 36.590 & 2.4539 \\ 39.560 & 2.2762 \\ 40.410 & 2.2303 \\ 42.520 & 2.1244 \\ 43.280 & 2.0888 \\ 44.780 & 2.0223 \\ 45.860 & 1.9771 \\ 47.530 & 1.9115 \\ 48.580 & 1.8726 \\ 50.190 & 1.8162 \\ 53.490 & 1.7117 \\ 54.885 & 1.6714 \\ 55.450 & 1.6557\end{array}$

Peak width Peak int [ 2 ] [counts]
0.480
0.480
0.120
0.320
0.280
0.160
0.160
0.080
0.240
0.120
0.100
0.120
0.080
0.120
0.240
0.140
0.060
0.200
0.400
0.120
0.400
0.080
0.160

$\begin{array}{rr}4 & 10 \\ 6 & 10 \\ 538 & 11 \\ 19 & 12 \\ 18 & 13 \\ 2450 & 14 \\ 48 & 14 \\ 190 & 15 \\ 61 & 17 \\ 30 & 18 \\ 154 & 18 \\ 172 & 18 \\ 79 & 17 \\ 146 & 16 \\ 24 & 16 \\ 12 & 16 \\ 106 & 15 \\ 29 & 15 \\ 26 & 14 \\ 269 & 14 \\ 21 & 14 \\ 55 & 14 \\ 19 & 14\end{array}$

Rel. int Signif. [\%]

$\begin{array}{rr}0.2 & 0.89 \\ 0.3 & 0.89 \\ 22.0 & 8.09 \\ 0.8 & 0.82 \\ 0.7 & 1.90 \\ 100.0 & 32.46 \\ 1.9 & 1.42 \\ 7.8 & 0.98 \\ 2.5 & 2.49 \\ 1.2 & 0.86 \\ 6.3 & 2.25 \\ 7.0 & 2.32 \\ 3.2 & 0.97 \\ 6.0 & 1.47 \\ 1.0 & 0.89 \\ 0.5 & 1.05 \\ 4.3 & 1.42 \\ 1.2 & 0.81 \\ 1.1 & 1.80 \\ 11.0 & 3.26 \\ 0.9 & 2.08 \\ 2.2 & 0.86 \\ 0.8 & 1.69\end{array}$


Angle d-value d-value Peak width Peak int Back. int Rel. int signif.

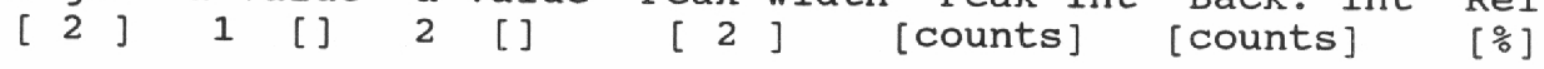

$\begin{array}{lrrrrrrr}57.355 & 1.6052 & 1.6091 & 0.400 & 10 & 14 & 0.4 & 1.13 \\ 60.010 & 1.5404 & 1.5442 & 0.100 & 202 & 15 & 8.2 & 2.45 \\ 60.180 & 1.5364 & 1.5402 & 0.080 & 96 & 15 & 3.9 & 1.28 \\ 64.050 & 1.4526 & 1.4562 & 0.200 & 34 & 12 & 1.4 & 2.03 \\ 65.850 & 1.4172 & 1.4207 & 0.240 & 11 & 13 & 0.4 & 1.12 \\ 67.770 & 1.3816 & 1.3850 & 0.080 & 104 & 13 & 4.2 & 1.29 \\ 68.220 & 1.3736 & 1.3770 & 0.120 & 234 & 14 & 9.6 & 3.32 \\ 68.410 & 1.3703 & 1.3736 & 0.120 & 161 & 14 & 6.6 & 0.96 \\ 73.480 & 1.2877 & 1.2909 & 0.160 & 30 & 10 & 1.2 & 1.30 \\ 75.685 & 1.2556 & 1.2587 & 0.080 & 48 & 10 & 1.9 & 1.51 \\ 77.675 & 1.2283 & 1.2313 & 0.080 & 29 & 10 & 1.2 & 0.98\end{array}$


Sample identification: PCC-CLAUDIA-T18X

Data measured at: 12-Aug-1998 1:23:00

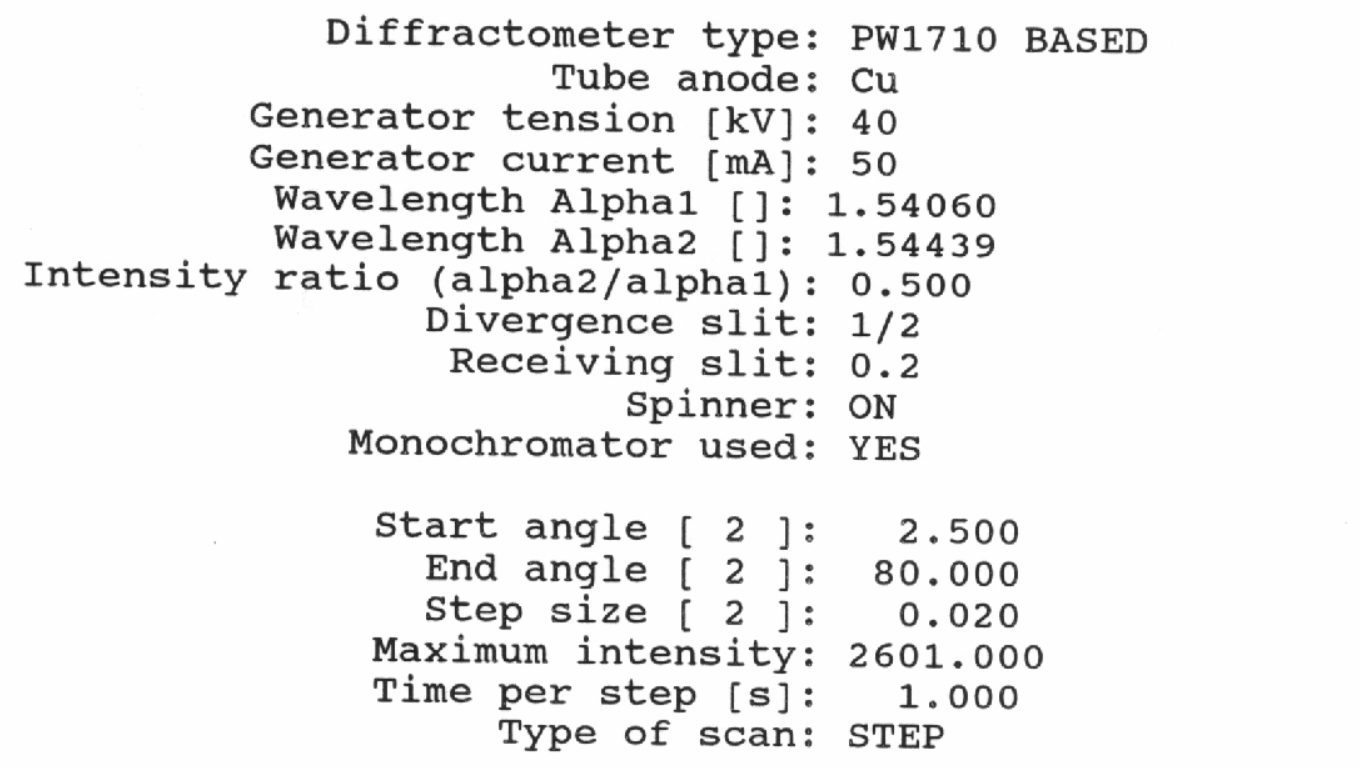

Minimum peak tip width: 0.05

Maximum peak tip width: 1.00

Peak base width: 2.00

Minimum significance: 0.75

Number of peaks: 48

Angle d-value d-value Peak width Peak int Back. int Rel. int Signif.

$$
\left[\begin{array}{ll}
2 & 2
\end{array}\right.
$$

8.840

11.210

12.310

13.800

18.620

20.880

21.080

23.065

25.000

25.720

26.690

27.115

27.515

29.480

32.520

35.935

36.565

37.840

39.510

40.370

42.480

42.945

45.795

$$
9.9952
$$

7.8868

7.1844

6.4119

4.7615

4.2510

4.2111

3.8530

3. 5590

3. 4609

3. 3373

3. 2860

3. 2391

3.0275

2. 7511

2. 4971

2.4555

2. 3757

2. 2790

2. 2324

2.1263

2. 1043

1. 9798

$$
2[]
$$

$$
10.0198
$$

7.9062

7.2021

6.4276

4.7732

4.2614

4. 2214

3. 8624

3.5677

3. 4695

3. 3455

3. 2941

3. 2471

3. 0350

2. 7579

2. 5032

2.4616

2. 3815

2. 2846

2. 2379

2. 1315

2. 1095

1.9846 $\left[\begin{array}{ll}2 & ]\end{array}\right.$

0.240
0.480
0.480
0.060
0.200
0.080
0.060
0.160
0.140
0.160
0.140
0.120
0.180
0.240
0.400
0.200
0.100
0.180
0.080
0.140
0.160
0.160
0.080
[counts] [counts]

10
12
8
28
48
454
125
36
16
23
2601
53
180
289
18
23
130
55
142
149
123
45
161

18

14

12

11

11

12

12

13

14

14

14

15

15

18

17

18

18

18

16

15

14

14

14
[\%]

$\begin{array}{rr}0.4 & 1.74 \\ 0.5 & 1.63 \\ 0.3 & 0.96 \\ 1.1 & 1.20 \\ 1.8 & 4.52 \\ 17.4 & 2.26 \\ 4.8 & 1.83 \\ 1.4 & 1.23 \\ 0.6 & 1.18 \\ 0.9 & 0.95 \\ 100.0 & 24.95 \\ 2.0 & 1.04 \\ 6.9 & 9.69 \\ 11.1 & 11.61 \\ 0.7 & 0.98 \\ 0.9 & 0.81 \\ 5.0 & 1.98 \\ 2.1 & 2.90 \\ 5.4 & 1.51 \\ 5.7 & 4.02 \\ 4.7 & 2.73 \\ 1.7 & 1.24 \\ 6.2 & 1.31\end{array}$


Angle d-value d-value $\left[\begin{array}{llllll} & 2 & ] & 1 & \text { [ ] } & 2\end{array}\right.$

47.535

48.590

50.165

50.660

53.360

54.880

55.315

57.340

58.250

59.970

60.155

61.630

62.395

64.055

65.810

67.755

67.940

68.170

68.340

68.560

73.475

73.660

75.680

75.895

77.795
1.9113

1.8722

1.8171

1.8005

1.7156

1. 6716

1.6595

1. 6056

1. 5826

1.5413

1. 5370

1.5037

1. 4871

1. 4525

1. 4180

1. 3819

1. 3786

1. 3745

1. 3715

1. 3676

1. 2878

1. 2850

1. 2557

1.2526

1. 2267
1.9160

1.8768

1.8215

1.8049

1.7198

1. 6757

1. 6635

1. 6095

1. 5865

1. 5451

1. 5408

1. 5074

1. 4908

1.4561

1. 4214

1. 3853

1. 3820

1. 3779

1. 3749

1. 3710

1. 2910

1. 2882

1. 2588

1. 2557

1. 2297
Peak width Peak int Back. int [ 2 ] [counts] [counts]

\subsection{0}

0.200

0.120

0.240

0.800

0.080

0.080

0.320

0.320

0.100

0.060

0.240

0.320

0.060

0.200

0.100

0.060

0.120

0.080

0.060

0.100

0.080

0.080

0.120

0.240

45
32
269
36
4
86
72
19
12
240
135
19
8
35
15
266
119
161
225
69
69
25
46
18
13

Rel. int Signif.

$[\%]$

13
13
12
12
12
12
12
12
12
11
11
11
11
11
11
11
11
11
11
11
11
11
10
10
9

1.7

1.2

10.3

1.4

0.1

3.3

2.8

0.7

0.5

9.2

5.2

0.7

0.3

1.3

0.6

10.2

4.6

6.2

8.7

2.6

2.6

1.0

1.8

0.7

0.5
0.92

0.88

3.29

2. 09

0.99

1.03

1.15

1.22

0.92

3.47

3.15

1.52

0.76

1.15

0.78

5.35

3.03

1.60

1. 84

0.88

1.98

1. 18

0.87

1.06

0.75 
Sample identification: PCC-CLAUDIA-S10 D

Data measured at: 3-Jul-1998 6:08:00

\author{
Diffractometer type: PW1710 BASED \\ Tube anode: $\mathrm{Cu}$ \\ Generator tension [kV]: 40 \\ Generator current [mA]: 40 \\ Wavelength Alpha1 []: 1.54060 \\ Wavelength Alpha2 []: 1.54439 \\ Intensity ratio (alpha2/alpha1): 0.500 \\ Divergence slit: $1 / 2$ \\ Receiving slit: 0.2 \\ Spinner: ON \\ Monochromator used: YES
Start angle [ 2 ]: 2.500
End angle [ 2 ]: 80.000
Step size [ 2 ]: 0.020
Maximum intensity: 5256.250
Time per step [s]: 1.000 Type of scan: STEP \\ $\begin{array}{rr}\text { Minimum peak tip width: } & 0.05 \\ \text { Maximum peak tip width: } & 1.00 \\ \text { Peak base width: } & 2.00 \\ \text { Minimum significance: } & 0.75 \\ \text { Number of peaks: } & 52\end{array}$
}

Angle d-value d-value Peak width Peak int Back. int Rel. int Signif.

[ 2 ]

2.605

8.965

11.245

12.520

13.750

17.885

18.680

20.985

23.145

23.900

25.065

25.770

26.775

27.630

29.485

30.930

32.560

34.985

36.060

36.675

37.925

39.570

40.390

\begin{abstract}
$1[$ ]
\end{abstract}
33.8877

9.8561

7.8623

7.0644

6.4351

4.9555

4.7464

4.2299

3.8398

3.7202

3.5499

3.4543

3.3269

3.2259

3.0270

2.8888

2. 7478

2. 5627

2.4887

2.4484

2. 3705

2. 2757

2.2314
$2[$ ]

\subsection{1}

9.8804

7.8817

7.0817

6.4509

4.9677

4.7580

4.2403

3. 8493

3.7294

3.5586

3. 4628

3. 3351

3. 2338

3. 0345

2. 8959

2.7546

2. 5690

2. 4949

2.4544

2. 3764

2. 2813

2. 2368
[ 2 ] [counts]

$$
0.240
$$

0.100

0.640

0.320

0.120

0.060

0.200

0.120

0.120

0.200

0.120

0.120

0.140

0.160

0.100

0.240

0.160

0.080

0.240

0.100

0.320

0.120

0.140

58
104
7
12
14
38
19
630
28
13
29
29
5256
276
219
12
41
41
34
219
27
172
85

[counts]

48
15

11

10

8

7

7

7

8

8

8

8

8

8

8

8

8

8

8

8

8

9

9

[\%]

$\begin{array}{rr}1.1 & 1.02 \\ 2.0 & 2.55 \\ 0.1 & 0.84 \\ 0.2 & 1.13 \\ 0.3 & 0.85 \\ 0.7 & 0.93 \\ 0.4 & 1.60 \\ 12.0 & 10.12 \\ 0.5 & 0.99 \\ 0.2 & 0.79 \\ 0.6 & 0.77 \\ 0.6 & 1.61 \\ 100.0 & 43.48 \\ 5.2 & 11.12 \\ 4.2 & 1.44 \\ 0.2 & 1.16 \\ 0.8 & 0.86 \\ 0.8 & 0.77 \\ 0.6 & 1.49 \\ 4.2 & 2.86 \\ 0.5 & 1.54 \\ 3.3 & 3.44 \\ 1.6 & 3.23\end{array}$




\begin{tabular}{|c|c|c|c|c|c|c|c|}
\hline $\begin{array}{l}\text { Angle } \\
{\left[\begin{array}{ll}2 & 2\end{array}\right]}\end{array}$ & $\begin{array}{c}\text { d-value } \\
1\end{array}$ & $\begin{array}{l}\text { d-value } \\
2 \quad[\text { ] }\end{array}$ & $\begin{array}{l}\text { Peak width } \\
{\left[\begin{array}{rl}2 & \text { l }\end{array}\right]}\end{array}$ & $\begin{array}{l}\text { Peak int } \\
\text { [counts] }\end{array}$ & $\begin{array}{l}\text { Back. int } \\
\text { [counts] }\end{array}$ & $\begin{array}{l}\text { Rel. } \\
{[\%]}\end{array}$ & Signif. \\
\hline 1.860 & 2.1563 & 2.1616 & 0.160 & 18 & 9 & 0.3 & 1.09 \\
\hline 2.575 & 2.1218 & 2.1270 & 0.100 & 317 & 9 & 6.0 & 4.40 \\
\hline 5.500 & 1.9919 & 1.9968 & 0.240 & 17 & 9 & 0.3 & 0.97 \\
\hline 5.870 & 1.9767 & 1.9816 & 0.120 & 83 & 9 & 1.6 & 2.25 \\
\hline 7.695 & 1.9053 & 1.9099 & 0.280 & 32 & 10 & 0.6 & 2.63 \\
\hline 8.590 & 1.8722 & 1.8768 & 0.160 & 32 & 10 & 0.6 & 0.84 \\
\hline 9.495 & 1.8401 & 1.8446 & 0.120 & 29 & 10 & 0.6 & 1.52 \\
\hline 50.205 & 1.8157 & 1.8202 & 0.120 & 493 & 10 & 9.4 & 6.96 \\
\hline 50.390 & 1.8095 & 1.8139 & 0.060 & 246 & 10 & 4.7 & 0.83 \\
\hline 3.560 & 1.7096 & 1.7138 & 0.480 & 8 & 10 & 0.2 & 1.57 \\
\hline 4.945 & 1.6698 & 1.6739 & 0.140 & 164 & 10 & 3.1 & 5.45 \\
\hline 5.115 & 1.6650 & 1.6691 & 0.080 & 72 & 10 & 1.4 & 0.87 \\
\hline .445 & 1.6559 & 1.6600 & 0.200 & 27 & 10 & 0.5 & 1.47 \\
\hline .375 & 1.6047 & 1.6086 & 0.320 & 19 & 10 & 0.4 & 1.61 \\
\hline .500 & 1.5765 & 1.5804 & 0.400 & 9 & 10 & 0.2 & 0.94 \\
\hline .040 & 1.5397 & 1.5435 & 0.080 & 156 & 10 & 3.0 & 1.48 \\
\hline 50.205 & 1.5358 & 1.5396 & 0.080 & 85 & 10 & 1.6 & 1.04 \\
\hline 2.365 & 1.4877 & 1.4914 & 0.120 & 28 & 10 & 0.5 & 1.27 \\
\hline 4.120 & 1.4512 & 1.4548 & 0.060 & 52 & 10 & 1.0 & 0.93 \\
\hline 5.755 & 1.4190 & 1.4225 & 0.480 & 10 & 11 & 0.2 & 0.79 \\
\hline 57.760 & 1.3818 & 1.3852 & 0.140 & 159 & 12 & 3.0 & 5.62 \\
\hline 37.995 & 1.3776 & 1.3810 & 0.060 & 128 & 12 & 2.4 & 1.61 \\
\hline 8.210 & 1.3738 & 1.3772 & 0.080 & 369 & 12 & 7.0 & 2.69 \\
\hline 8.425 & 1.3700 & 1.3734 & 0.100 & 210 & 12 & 4.0 & 2.47 \\
\hline 3.520 & 1.2871 & 1.2903 & 0.100 & 53 & 11 & 1.0 & 1.36 \\
\hline 3.765 & 1.2835 & 1.2866 & 0.080 & 22 & 11 & 0.4 & 0.91 \\
\hline 5.700 & 1.2554 & 1.2585 & 0.100 & 67 & 10 & 1.3 & 2.14 \\
\hline 5.945 & 1.2519 & 1.2550 & 0.100 & 35 & 10 & 0.7 & 1.12 \\
\hline 7.705 & 1.2279 & 1.2309 & 0.080 & 21 & 10 & 0.4 & 0.86 \\
\hline
\end{tabular}


Sample identification: PCC-CLAUDIA-S10 F

Data measured at: 3-Jul-1998 7:24:00

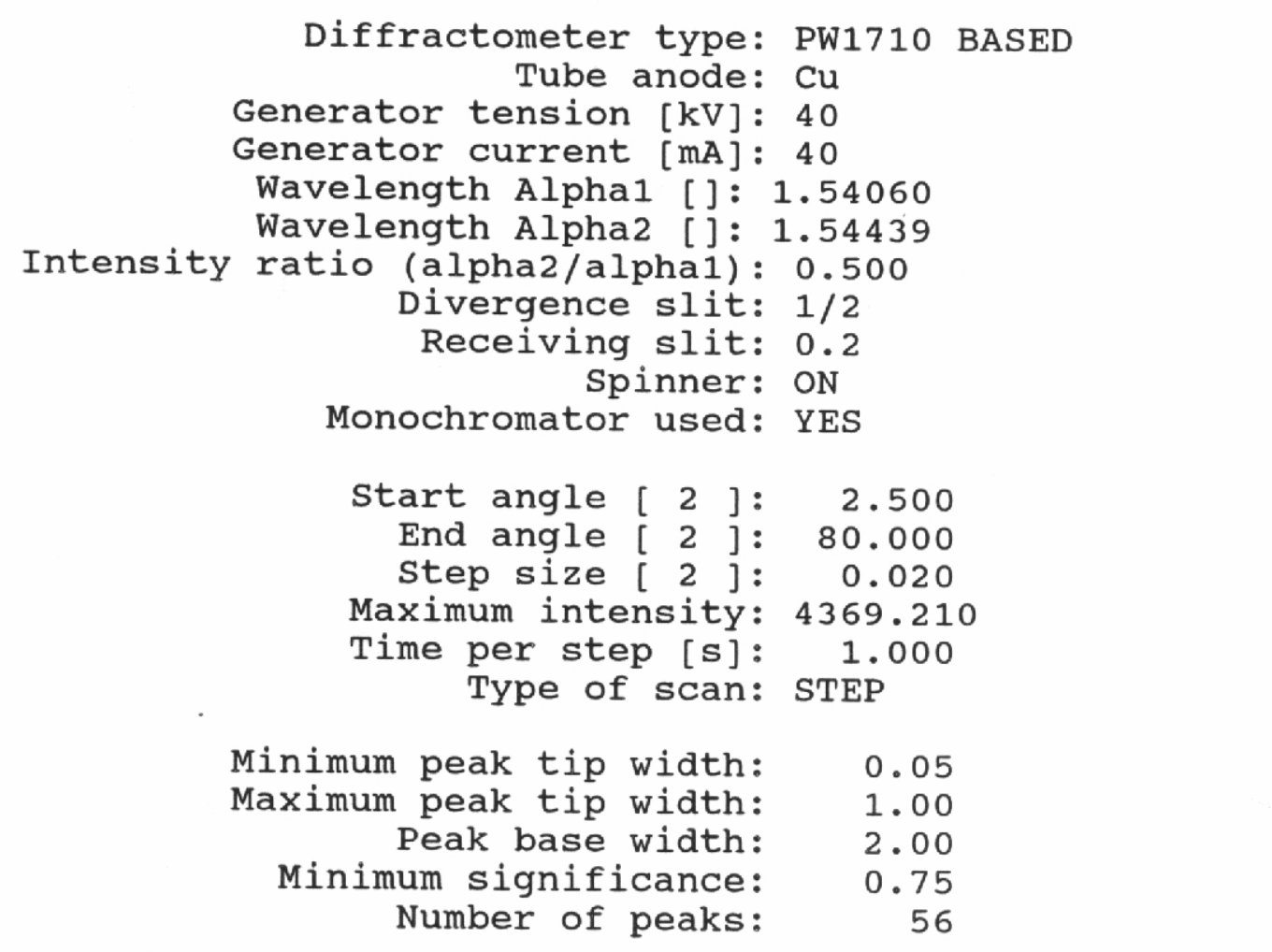

Angle

$[2]$
8.935
10.555
11.100
12.330
13.735
17.885
18.615
19.280
20.620
20.925
22.305
23.095
23.995
24.950
25.630
26.745
27.555
29.450
30.900
32.320
34.810
35.975
36.615

d-value

$1[$ ]

9.8891

8.3747

7.9647

7.1728

6.4421

4.9555

4.7628

4.6000

4.3040

4.2419

3.9825

3.8480

3.7057

3.5660

3.4729

3.3306

3. 2345

3. 0305

2. 8915

2.7677

2. 5752

2. 4944

2.4523 d-value

$$
2 \text { [ ] }
$$

9.9135

8.3953

7.9843

7.1904

6.4579

4. 9677

4.7745

4.6113

4. 3146

4. 2524

3.9923

3. 8575

3. 7148

3. 5748

3. 4814

3.3388

3. 2424

3.0380

2. 8987

2.7745

2. 5815

2. 5006

2. 4583
Peak width

[ 2 ]

$$
0.100
$$

0.100

0.400

0.400

0.080

0.160

0.160

0.240

0.080

0.120

0.120

0.160

0.200

0.240

0.160

0.160

0.140

0.100

0.160

0.200

0.160

0.200

0.060
Peak int [counts]

50
180
14
12
27
13
50
10
96
548
31
34
11
24
28
4369
824
219
25
28
24
32
331

Back. int [counts]

15
13
12
12
10
7
8
8
8
8
8
8
8
8
8
8
8
8
8
9
9
9
9

Rel. int Signif. [\%]

$\begin{array}{rr}1.2 & 1.61 \\ 4.1 & 5.96 \\ 0.3 & 1.00 \\ 0.3 & 1.45 \\ 0.6 & 0.91 \\ 0.3 & 0.78 \\ 1.2 & 1.68 \\ 0.2 & 1.11 \\ 2.2 & 1.53 \\ 12.5 & 8.36 \\ 0.7 & 1.24 \\ 0.8 & 0.86 \\ 0.2 & 0.87 \\ 0.5 & 2.40 \\ 0.6 & 1.20 \\ 100.0 & 49.29 \\ 18.9 & 14.36 \\ 5.0 & 1.23 \\ 0.6 & 1.45 \\ 0.6 & 1.14 \\ 0.5 & 1.07 \\ 0.7 & 1.49 \\ 7.6 & 1.36\end{array}$




\begin{tabular}{|c|c|c|c|c|c|c|c|}
\hline $\begin{array}{l}\text { Angle } \\
{\left[\begin{array}{ll}2\end{array}\right]}\end{array}$ & $\begin{array}{c}\text { d-value } \\
1\end{array}$ & $\begin{array}{l}\text { d-value } \\
2 \quad[]\end{array}$ & $\begin{array}{l}\text { Peak width } \\
{\left[\begin{array}{rl}2 & 3\end{array}\right]}\end{array}$ & $\begin{array}{l}\text { Peak int } \\
\text { [counts] }\end{array}$ & $\begin{array}{l}\text { Back. int } \\
\text { [counts] }\end{array}$ & $\begin{array}{l}\text { Rel. int } \\
{[\%]}\end{array}$ & Signif. \\
\hline 37.845 & 2.3754 & 2.3812 & 0.160 & 42 & 9 & 1.0 & 1.20 \\
\hline 39.550 & 2.2768 & 2.2824 & 0.120 & 253 & 10 & 5.8 & 4.41 \\
\hline 40.345 & 2.2337 & 2.2392 & 0.080 & 154 & 10 & 3.5 & 1.76 \\
\hline 41.855 & 2.1566 & 2.1619 & 0.120 & 18 & 10 & 0.4 & 1.42 \\
\hline 42.520 & 2.1244 & 2.1296 & 0.120 & 135 & 10 & 3.1 & 2.98 \\
\hline 42.970 & 2.1032 & 2.1083 & 0.200 & 49 & 10 & 1.1 & 1.51 \\
\hline 43.775 & 2.0663 & 2.0714 & 0.120 & 55 & 10 & 1.3 & 1.42 \\
\hline 45.865 & 1.9769 & 1.9818 & 0.100 & 142 & 10 & 3.2 & 2.39 \\
\hline 47.615 & 1.9083 & 1.9130 & 0.240 & 31 & 10 & 0.7 & 1.55 \\
\hline 48.525 & 1.8746 & 1.8792 & 0.240 & 28 & 10 & 0.6 & 0.83 \\
\hline 50.200 & 1.8159 & 1.8204 & 0.120 & 571 & 10 & 13.1 & 6.71 \\
\hline 50.365 & 1.8103 & 1.8148 & 0.060 & 282 & 10 & 6.5 & 1.18 \\
\hline 54.920 & 1.6705 & 1.6746 & 0.080 & 81 & 11 & 1.9 & 1.43 \\
\hline 55.325 & 1.6592 & 1.6633 & 0.080 & 34 & 11 & 0.8 & 0.83 \\
\hline 57.420 & 1.6035 & 1.6075 & 0.360 & 10 & 11 & 0.2 & 2.07 \\
\hline 58.200 & 1.5839 & 1.5878 & 0.120 & 13 & 11 & 0.3 & 0.83 \\
\hline 59.985 & 1.5409 & 1.5447 & 0.120 & 240 & 11 & 5.5 & 3.65 \\
\hline 60.180 & 1.5364 & 1.5402 & 0.060 & 106 & 11 & 2.4 & 1.49 \\
\hline 62.375 & 1.4875 & 1.4912 & 0.320 & 14 & 10 & 0.3 & 1.13 \\
\hline 64.050 & 1.4526 & 1.4562 & 0.080 & 119 & 10 & 2.7 & 1.73 \\
\hline 64.235 & 1.4489 & 1.4524 & 0.060 & 52 & 10 & 1.2 & 0.97 \\
\hline 66.385 & 1.4071 & 1.4105 & 0.400 & 7 & 11 & 0.2 & 1.27 \\
\hline 67.765 & 1.3817 & 1.3851 & 0.120 & 180 & 11 & 4.1 & 3.83 \\
\hline 67.945 & 1.3785 & 1.3819 & 0.080 & 123 & 11 & 2.8 & 0.91 \\
\hline 68.325 & 1.3718 & 1.3751 & 0.120 & 246 & 11 & 5.6 & 4.87 \\
\hline 68.565 & 1.3675 & 1.3709 & 0.120 & 125 & 11 & 2.9 & 2.70 \\
\hline 71.740 & 1.3146 & 1.3179 & 0.480 & 4 & 11 & 0.1 & 0.80 \\
\hline 73.465 & 1.2880 & 1.2911 & 0.140 & 76 & 10 & 1.7 & 3.40 \\
\hline 73.660 & 1.2850 & 1.2882 & 0.080 & 40 & 10 & 0.9 & 0.76 \\
\hline 75.680 & 1.2557 & 1.2588 & 0.100 & 98 & 10 & 2.2 & 1.44 \\
\hline 75.885 & 1.2528 & 1.2559 & 0.100 & 62 & 10 & 1.4 & 1.68 \\
\hline 77.700 & 1.2280 & 1.2310 & 0.160 & 19 & 10 & 0.4 & 0.75 \\
\hline 78.680 & 1.2151 & 1.2181 & 0.120 & 13 & 11 & 0.3 & 1.39 \\
\hline
\end{tabular}


Sample identification: PCC-CLAUDIA-S11A

Data measured at: 23-Jul-1998 10:37:00

\author{
Diffractometer type: PW1710 BASED \\ Tube anode: $\mathrm{Cu}$ \\ Generator tension $[\mathrm{kV}]: 40$ \\ Generator current [mA]: 40 \\ Wavelength Alpha1 []: 1.54060 \\ Wavelength Alpha2 []: 1.54439 \\ Intensity ratio (alpha2/alpha1): 0.500 \\ Divergence slit: 1 \\ Receiving slit: 0.2 \\ Spinner: ON \\ Monochromator used: YES \\ Start angle [ 2 ] : 2.500 \\ End angle [ 2 ]: 70.000 \\ Step size [ 2 ]: 0.020 \\ Maximum intensity: 3058.090 \\ Time per step [s]: 0.500 \\ Type of scan: STEP \\ Minimum peak tip width: 0.05 \\ Maximum peak tip width: 1.00 \\ Peak base width: 2.00 \\ Minimum significance: 0.75 \\ Number of peaks: 40
}

\begin{tabular}{|c|c|c|c|c|c|c|c|}
\hline $\begin{array}{l}\text { Angle } \\
{\left[\begin{array}{ll}2 & 2\end{array}\right]}\end{array}$ & $\begin{array}{c}\text { d-value } \\
1\end{array}$ & $\begin{array}{l}\text { d-value } \\
2 \quad[]\end{array}$ & $\begin{array}{l}\text { Peak width } \\
{\left[\begin{array}{rl}2 & ]\end{array}\right.}\end{array}$ & $\begin{array}{l}\text { Peak int } \\
\text { [counts] }\end{array}$ & $\begin{array}{l}\text { Back, int } \\
\text { [counts] }\end{array}$ & $\begin{array}{l}\text { Rel. int } \\
{[\%]}\end{array}$ & Signif. \\
\hline 8.935 & 9.8891 & 9.9135 & 0.160 & 30 & 6 & 1.0 & 1.93 \\
\hline 11.255 & 7.8553 & 7.8747 & 0.640 & 5 & 5 & 0.2 & 0.84 \\
\hline 13.745 & 6.4374 & 6.4532 & 0.120 & 8 & 4 & 0.3 & 1.13 \\
\hline 17.910 & 4.9486 & 4.9608 & 0.120 & 10 & 3 & 0.3 & 2.67 \\
\hline 20.960 & 4.2349 & 4.2453 & 0.120 & 243 & 4 & 8.0 & 5.09 \\
\hline 23.140 & 3.8407 & 3.8501 & 0.160 & 18 & 5 & 0.6 & 0.97 \\
\hline 26.790 & 3.3251 & 3.3333 & 0.140 & 3058 & 6 & 100.0 & 33.27 \\
\hline 27.610 & 3.2282 & 3.2361 & 0.160 & 46 & 5 & 1.5 & 2.04 \\
\hline 29.570 & 3.0185 & 3.0259 & 0.080 & 169 & 5 & 5.5 & 1.36 \\
\hline 30.895 & 2.8920 & 2.8991 & 0.120 & 8 & 4 & 0.3 & 0.86 \\
\hline 33.230 & 2.6939 & 2.7006 & 0.240 & 4 & 4 & 0.1 & 0.77 \\
\hline 34.795 & 2.5763 & 2.5826 & 0.480 & 6 & 4 & 0.2 & 1.23 \\
\hline 36.080 & 2.4874 & 2.4935 & 0.240 & 17 & 4 & 0.5 & 2.25 \\
\hline 36.660 & 2.4494 & 2.4554 & 0.080 & 154 & 4 & 5.0 & 1.80 \\
\hline 38.655 & 2.3274 & 2.3331 & 0.400 & 4 & 4 & 0.1 & 1.28 \\
\hline 39.570 & 2.2757 & 2.2813 & 0.120 & 204 & 4 & 6.7 & 4.33 \\
\hline 40.425 & 2.2295 & 2.2350 & 0.200 & 58 & 4 & 1.9 & 3.90 \\
\hline 41.825 & 2.1581 & 2.1634 & 0.160 & 4 & 4 & 0.1 & 0.77 \\
\hline 42.525 & 2.1241 & 2.1294 & 0.100 & 46 & 4 & 1.5 & 1.32 \\
\hline 43.275 & 2.0890 & 2.0942 & 0.160 & 19 & 4 & 0.6 & 0.90 \\
\hline 45.880 & 1.9763 & 1.9812 & 0.080 & 46 & 4 & 1.5 & 0.83 \\
\hline 47.675 & 1.9060 & 1.9107 & 0.240 & 20 & 4 & 0.7 & 1.67 \\
\hline 48.600 & 1.8719 & 1.8765 & 0.240 & 23 & 4 & 0.8 & 0.84 \\
\hline
\end{tabular}


Angle d-value d-value Peak width Peak int Back. int Rel. int Signif.

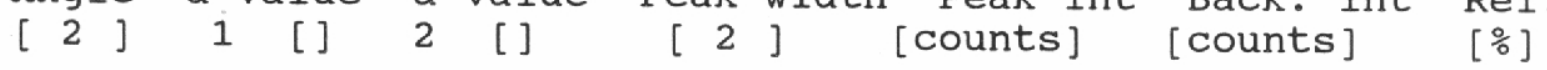

$\begin{array}{llllr}50.245 & 1.8144 & 1.8188 & 0.120 & 166 \\ 50.395 & 1.8093 & 1.8138 & 0.060 & 85 \\ 54.985 & 1.6686 & 1.6727 & 0.100 & 299 \\ 55.150 & 1.6640 & 1.6681 & 0.060 & 146 \\ 56.635 & 1.6239 & 1.6279 & 0.320 & 6 \\ 57.540 & 1.6005 & 1.6044 & 0.320 & 6 \\ 59.120 & 1.5614 & 1.5653 & 0.060 & 5 \\ 60.060 & 1.5392 & 1.5430 & 0.100 & 169 \\ 60.240 & 1.5350 & 1.5388 & 0.080 & 71 \\ 64.105 & 1.4515 & 1.4551 & 0.080 & 108 \\ 64.285 & 1.4479 & 1.4514 & 0.080 & 58 \\ 66.480 & 1.4053 & 1.4087 & 0.200 & 10 \\ 67.835 & 1.3805 & 1.3839 & 0.120 & 86 \\ 68.000 & 1.3775 & 1.3809 & 0.080 & 66 \\ 68.210 & 1.3738 & 1.3772 & 0.080 & 159 \\ 68.395 & 1.3705 & 1.3739 & 0.100 & 272 \\ 68.600 & 1.3669 & 1.3703 & 0.060 & 96\end{array}$

$5.4 \quad 3.74$

$2.8 \quad 1.55$

$9.8 \quad 4.66$

$4.8 \quad 0.75$

$0.2 \quad 1.04$

$0.2 \quad 2.03$

$0.2 \quad 0.75$

$5.5 \quad 2.54$

$2.3 \quad 2.56$

$3.5 \quad 1.73$

$1.9 \quad 1.03$

$0.3 \quad 0.86$

$2.8 \quad 3.22$

$2.1 \quad 0.89$

$5.2 \quad 1.70$

$8.9 \quad 3.30$

$\begin{array}{lllll}68.600 & 1.3669 & 1.3703 & 0.060 & 96\end{array}$

$3.1 \quad 2.19$ 


\author{
Sample identification: PCC-CLAUDIA-S12BA \\ Data measured at: 23-Jul-1998 11:52:00 \\ Diffractometer type: PW1710 BASED \\ Tube anode: $\mathrm{Cu}$ \\ Generator tension $[\mathrm{kV}]: 40$ \\ Generator current [mA]: 40 \\ Wavelength Alpha1 []: 1.54060 \\ Wavelength Alpha2 []: 1.54439 \\ Intensity ratio (alpha2/alpha1): 0.500 \\ Divergence slit: 1 \\ Receiving slit: 0.2 \\ Spinner: ON \\ Monochromator used: YES

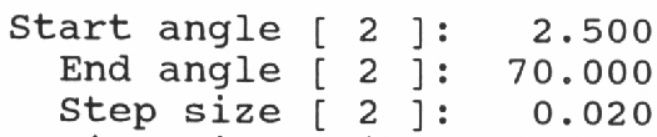 \\ Maximum intensity: 1962.490 \\ Time per step [s]: 0.500 \\ Type of scan: STEP \\ Minimum peak tip width: 0.05 \\ Maximum peak tip width: 1.00 \\ Peak base width: 2.00 \\ Minimum significance: 0.75 \\ Number of peaks: $\quad 39$
}

\begin{tabular}{|c|c|c|c|c|c|c|c|}
\hline $\begin{array}{l}\text { Angle } \\
{\left[\begin{array}{ll}2 & 2\end{array}\right]}\end{array}$ & $\begin{array}{c}\text { d-value } \\
1\end{array}$ & $\begin{array}{l}\text { d-value } \\
2 \quad[]\end{array}$ & $\begin{array}{cl}k & \text { width } \\
2 & ]\end{array}$ & $\begin{array}{l}\text { Peak int } \\
\text { [counts] }\end{array}$ & $\begin{array}{l}\text { Back. int } \\
\text { [counts] }\end{array}$ & $\begin{array}{l}\text { Rel. int } \\
{[\%]}\end{array}$ & Signif. \\
\hline 2.645 & 33.3753 & 33.4574 & 0.480 & 36 & 26 & 1.8 & 1.66 \\
\hline 8.900 & 9.9279 & 9.9524 & 0.120 & 21 & 7 & 1.1 & 2.95 \\
\hline 1.390 & 7.7625 & 7.7816 & 0.640 & 5 & 5 & 0.2 & 0.86 \\
\hline 3.710 & 6.4537 & 6.4696 & 0.120 & 13 & 4 & 0.7 & 1.79 \\
\hline 7.835 & 4.9693 & 4.9815 & 0.120 & 5 & 4 & 0.3 & 0.81 \\
\hline 0.905 & 4.2459 & 4.2564 & 0.080 & 234 & 4 & 11.9 & 1.98 \\
\hline 3.125 & 3.8431 & 3.8526 & 0.200 & 12 & 4 & 0.6 & 0.85 \\
\hline 3.950 & 3.7126 & 3.7217 & 0.120 & 13 & 4 & 0.7 & 1.03 \\
\hline 25.630 & 3.4729 & 3.4814 & 0.240 & 8 & 4 & 0.4 & 0.87 \\
\hline 26.730 & 3.3324 & 3.3406 & 0.140 & 1962 & 4 & 100.0 & 25.11 \\
\hline 27.555 & 3.2345 & 3.2424 & 0.120 & 286 & 4 & 14.6 & 7.07 \\
\hline 29.485 & 3.0270 & 3.0345 & 0.100 & 130 & 4 & 6.6 & 1.79 \\
\hline 32.460 & 2.7561 & 2.7628 & 0.400 & 17 & 4 & 0.9 & 2.12 \\
\hline 34.990 & 2.5623 & 2.5687 & 0.240 & 15 & 4 & 0.8 & 2.00 \\
\hline 36.015 & 2.4917 & 2.4979 & 0.240 & 14 & 4 & 0.7 & 2.22 \\
\hline 6.590 & 2.4539 & 2.4599 untos & 0.100 & 77 & 4 & 3.9 & 1.84 \\
\hline 37.980 & 2.3672 & 2.3730 & 0.200 & 6 & 4 & 0.3 & 0.82 \\
\hline 39.535 & 2.2776 & 2.2832 quartor & 0.120 & 96 & 4 & 4.9 & 2.62 \\
\hline 40.465 & 2.2274 & 2.2329 & 0.140 & 28 & 4 & 1.4 & 1.13 \\
\hline 41.870 & 2.1558 & 2.1611 & 0.120 & 10 & 4 & 0.5 & 0.83 \\
\hline 42.515 & 2.1246 & 2.1298 equatho & 0.200 & 61 & 4 & 3.1 & 3.69 \\
\hline 43.195 & 2.0927 & 2.0979 & 0.320 & 13 & 4 & 0.7 & 0.98 \\
\hline 45.850 & 1.9775 & 1.9824 equartwo & 0.080 & 86 & 4 & 4.4 & 1.37 \\
\hline
\end{tabular}


Angle d-value d-value Peak width Peak int Back. int Rel. int Signif. $\left[\begin{array}{llllllllll}2 & ] & 1 & {[} & 2 & \text { [ ] } & {\left[\begin{array}{lll}2 & \end{array}\right]} & \text { [counts] [counts] }\end{array}\right.$

\begin{tabular}{|c|c|c|c|c|c|c|c|}
\hline 47.600 & 1.9088 & 1.9135 & 0.320 & 14 & 4 & 0.7 & 1.11 \\
\hline 48.620 & 1.8711 & 1.8757 & 0.320 & 14 & 4 & 0.7 & 1.41 \\
\hline 49.055 & 1.8556 & 1.8601 & 0.120 & 10 & 4 & 0.5 & 0.75 \\
\hline 50.200 & 1.8159 & 1.8204 gurthos & 0.100 & 306 & 4 & 15.6 & 3.91 \\
\hline 50.355 & 1.8107 & 1.8151 & 0.080 & 146 & 4 & 7.5 & 1.46 \\
\hline 54.925 & 1.6703 & 1.6744 uartio & 0.100 & 128 & 6 & 6.5 & 2.36 \\
\hline 55.080 & 1.6660 & 1.6701 & 0.060 & 66 & 6 & $3 \cdot 3$ & 1.71 \\
\hline 55.325 & 1.6592 & 1.6633 vartio & 0.080 & 27 & 6 & 1.4 & 1.25 \\
\hline 57.360 & 1.6051 & 1.6090 un too & 0.240 & 13 & 5 & 0.7 & 0.81 \\
\hline 59.965 & 1.5414 & 1.5452 mantroo & 0.120 & 106 & 5 & 5.4 & 2.60 \\
\hline 60.155 & 1.5370 & 1.5408 & 0.100 & 62 & 5 & 3.2 & 0.94 \\
\hline 61.465 & 1.5073 & 1.5111 & 0.800 & 4 & 5 & 0.2 & 0.96 \\
\hline 64.070 & 1.4522 & 1.4558 quartion & 0.120 & 27 & 6 & 1.4 & 2.44 \\
\hline 67.785 & 1.3814 & 1. 3848 quartio & 0.100 & 114 & 5 & 5.8 & 2.86 \\
\hline 68.180 & 1.3743 & 1.3777 querth & 0.080 & 85 & 5 & 4.3 & 0.90 \\
\hline 68.390 & 1.3706 & 1.3740 qumbo & 0.080 & 67 & 5 & 3.4 & 0.78 \\
\hline
\end{tabular}




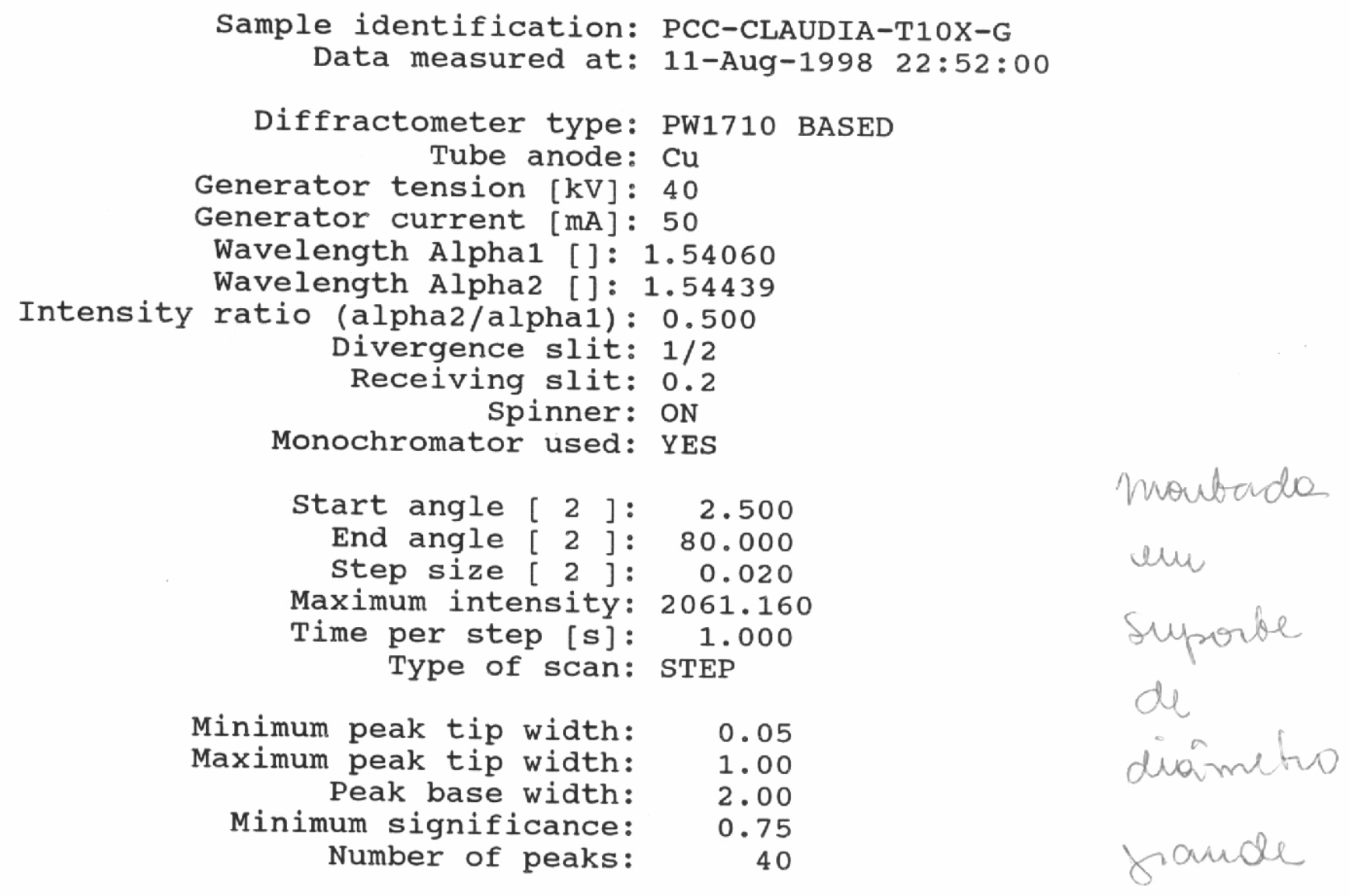

Angle d-value d-value

$\begin{array}{rr}{[2]} & 1 \\ 7] \\ 7.540 & 11.7153 \\ 8.860 & 9.9727 \\ 11.030 & 8.0151 \\ 12.285 & 7.1990 \\ 15.010 & 5.8976 \\ 18.410 & 4.8154 \\ 20.880 & 4.2510 \\ 23.040 & 3.8571 \\ 25.635 & 3.4722 \\ 26.680 & 3.3385 \\ 27.075 & 3.2907 \\ 27.525 & 3.2379 \\ 29.400 & 3.0356 \\ 29.520 & 3.0235 \\ 30.835 & 2.8975 \\ 32.305 & 2.7689 \\ 34.310 & 2.6116 \\ 35.960 & 2.4954 \\ 36.600 & 2.4532 \\ 39.510 & 2.2790 \\ 40.310 & 2.2356 \\ 41.815 & 2.1585 \\ 42.545 & 2.1232\end{array}$

2 [ ]

$$
11.7442
$$

9.9972

8.0348

7.2167

5.9121

4.8272

4.2614

3.8666

3.4808

3. 3468

3.2988

3.2459

3.0430

3.0309

2.9046

2.7757

2. 6180

2.5016

2.4593

2.2846

2.2411

2.1639

2.1284
Peak width [ 2

$$
\begin{aligned}
& 0.240 \\
& 0.240 \\
& 0.800 \\
& 0.320 \\
& 0.480 \\
& 0.320
\end{aligned}
$$

0.120

0.120

0.200

0.140

0.100

0.160

0.100

0.080

0.160

0.200

0.320

0.160

0.160

0.080

0.100

0.140

0.160
Peak int [counts]

$\begin{array}{rl}37 & 24 \\ 8 & 20 \\ 10 & 16 \\ 8 & 14 \\ 5 & 11 \\ 7 & 11 \\ 458 & 11 \\ 49 & 12 \\ 27 & 12 \\ 2061 & 12 \\ 62 & 12 \\ 79 & 12 \\ 369 & 13 \\ 262 & 13 \\ 30 & 13 \\ 49 & 13 \\ 15 & 14 \\ 45 & 14 \\ 139 & 14 \\ 156 & 14 \\ 71 & 15 \\ 22 & 15 \\ 79 & 15\end{array}$

Rel. int signif. [\%]

$\begin{array}{rr}1.8 & 1.84 \\ 0.4 & 0.89 \\ 0.5 & 1.68 \\ 0.4 & 0.75 \\ 0.2 & 1.02 \\ 0.3 & 0.86 \\ 22.2 & 7.92 \\ 2.4 & 1.80 \\ 1.3 & 1.18 \\ 100.0 & 23.03 \\ 3.0 & 0.90 \\ 3.8 & 2.13 \\ 17.9 & 1.70 \\ 12.7 & 0.92 \\ 1.5 & 1.17 \\ 2.4 & 0.90 \\ 0.7 & 0.76 \\ 2.2 & 0.85 \\ 6.8 & 4.88 \\ 7.6 & 0.89 \\ 3.4 & 1.47 \\ 1.1 & 1.05 \\ 3.8 & 2.41\end{array}$


File:

Angle d-value d-value Peak width Peak int Back. int Rel. int Signif.

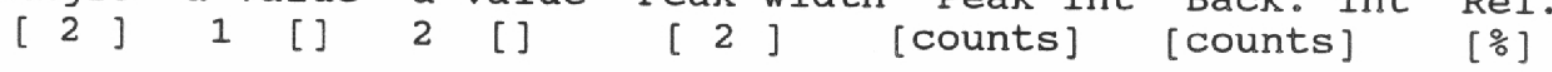

$\begin{array}{llllrrrr}43.125 & 2.0960 & 2.1011 & 0.320 & 52 & 15 & 2.5 & 1.67 \\ 45.840 & 1.9779 & 1.9828 & 0.200 & 56 & 16 & 2.7 & 2.97 \\ 47.560 & 1.9103 & 1.9150 & 0.320 & 50 & 16 & 2.4 & 2.16 \\ 48.485 & 1.8760 & 1.8807 & 0.200 & 50 & 16 & 2.4 & 1.77 \\ 50.120 & 1.8186 & 1.8231 & 0.080 & 132 & 17 & 6.4 & 1.08 \\ 53.600 & 1.7084 & 1.7126 & 0.640 & 11 & 14 & 0.5 & 1.29 \\ 54.865 & 1.6720 & 1.6761 & 0.060 & 71 & 14 & 3.4 & 1.27 \\ 55.315 & 1.6595 & 1.6635 & 0.120 & 24 & 14 & 1.2 & 1.10 \\ 57.335 & 1.6057 & 1.6097 & 0.320 & 20 & 14 & 1.0 & 1.09 \\ 59.960 & 1.5415 & 1.5453 & 0.080 & 149 & 17 & 7.2 & 1.12 \\ 64.020 & 1.4532 & 1.4568 & 0.120 & 24 & 14 & 1.2 & 0.79 \\ 65.785 & 1.4184 & 1.4219 & 0.240 & 12 & 14 & 0.6 & 0.90 \\ 67.725 & 1.3824 & 1.3858 & 0.100 & 64 & 14 & 3.1 & 0.94 \\ 68.165 & 1.3746 & 1.3780 & 0.060 & 96 & 14 & 4.7 & 0.97 \\ 73.490 & 1.2876 & 1.2907 & 0.160 & 23 & 12 & 1.1 & 0.81 \\ 75.655 & 1.2560 & 1.2591 & 0.120 & 25 & 10 & 1.2 & 1.58 \\ 77.675 & 1.2283 & 1.2313 & 0.060 & 27 & 10 & 1.3 & 0.81\end{array}$


Sample identification: PCC-CLAUDIA-S19A

Data measured at: 12-Aug-1998 2:38:00

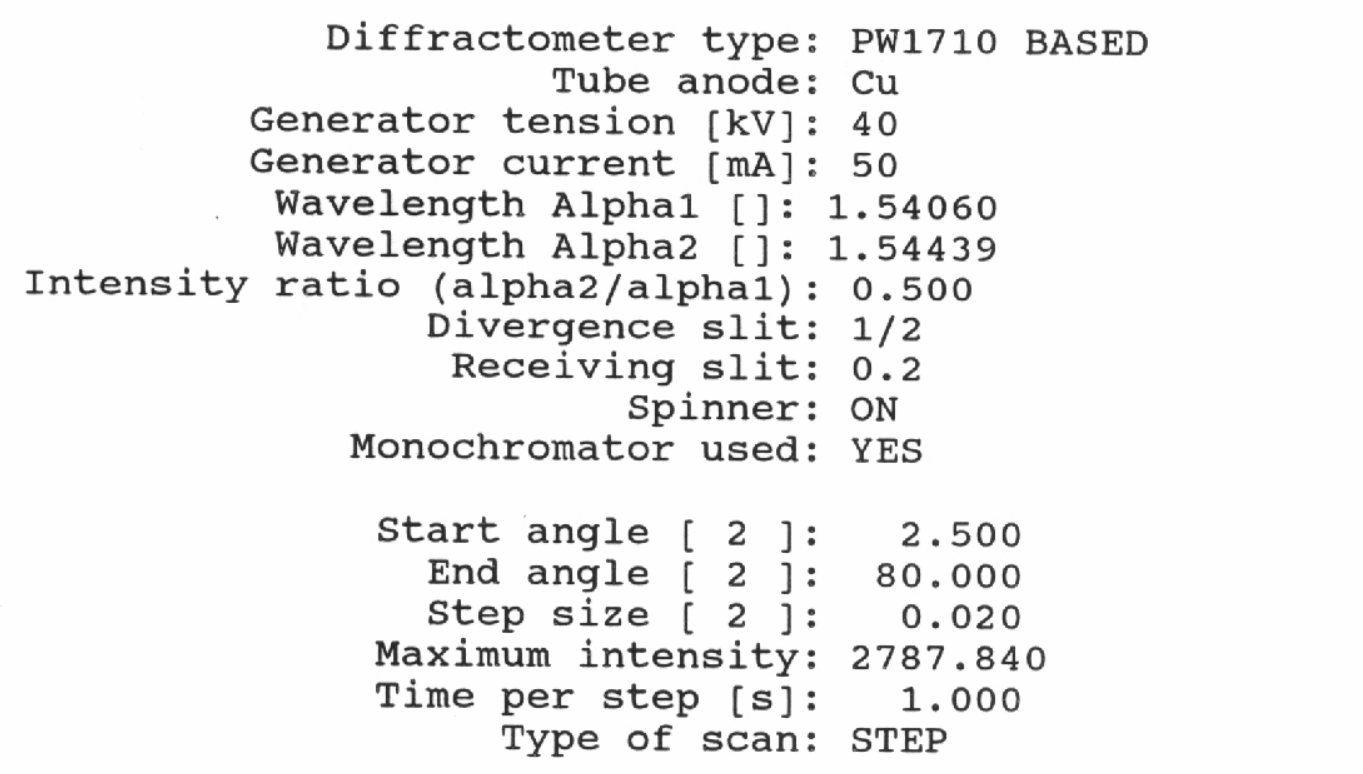

Minimum peak tip width: 0.05

Maximum peak tip width: 1.00

Peak base width: 2.00

Minimum significance: 0.75

Number of peaks: $\quad 37$

Angle d-value d-value Peak width Peak int Back. int Rel. int Signif.

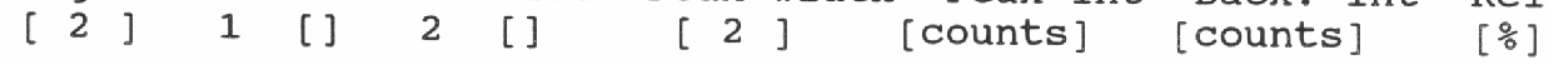

\begin{tabular}{|c|c|c|c|c|c|c|c|}
\hline 19.385 & 4.5753 & 4.5866 & 0.160 & 13 & 8 & 0.5 & 1.29 \\
\hline 20.940 & 4.2389 & 4.2494 & 0.120 & 640 & 8 & 23.0 & 9.03 \\
\hline 23.420 & 3.7954 & 3.8047 & 0.160 & 42 & 9 & 1.5 & 1.00 \\
\hline 25.745 & 3.4576 & 3.4661 & 0.200 & 46 & 10 & 1.7 & 2.83 \\
\hline 26.755 & 3.3294 & 3.3375 & 0.160 & 2788 & 10 & 100.0 & 33.68 \\
\hline 27.620 & 3.2270 & 3.2350 & 0.160 & 64 & 10 & 2.3 & 2.42 \\
\hline 29.470 & 3.0285 & 3.0360 & 0.160 & 125 & 10 & 4.5 & 2.76 \\
\hline 30.920 & 2.8897 & 2.8968 & 0.240 & 17 & 11 & 0.6 & 1.28 \\
\hline 32.405 & 2.7606 & 2.7674 & 0.320 & 20 & 11 & 0.7 & 1.37 \\
\hline 34.665 & 2.5856 & 2.5920 & 0.800 & 6 & 12 & 0.2 & 0.75 \\
\hline 36.625 & 2.4516 & 2.4577 & 0.100 & 276 & 12 & 9.9 & 3.09 \\
\hline 39.545 & 2.2771 & 2.2827 & 0.060 & 169 & 13 & 6.1 & 1.69 \\
\hline 40.415 & 2.2300 & 2.2355 & 0.060 & 117 & 13 & 4.2 & 1.69 \\
\hline 41.830 & 2.1578 & 2.1631 & 0.120 & 13 & 14 & 0.5 & 0.95 \\
\hline 42.550 & 2.1229 & 2.1282 & 0.080 & 193 & 14 & 6.9 & 1.02 \\
\hline 45.840 & 1.9779 & 1.9828 & 0.080 & 92 & 12 & 3.3 & 1.30 \\
\hline 47.485 & 1.9132 & 1.9179 & 0.240 & 19 & 12 & 0.7 & 1.12 \\
\hline 48.575 & 1.8728 & 1.8774 & 0.320 & 20 & 12 & 0.7 & 0.97 \\
\hline 50.205 & 1.8157 & 1.8202 & 0.120 & 376 & 12 & 13.5 & 5.27 \\
\hline 54.895 & 1.6712 & 1.6753 & 0.100 & 85 & 12 & 3.0 & 1.11 \\
\hline 55.390 & 1.6574 & 1.6615 & 0.120 & 52 & 12 & 1.9 & 0.78 \\
\hline 56.545 & 1.6263 & 1.6303 & 0.120 & 5 & 12 & 0.2 & 0.83 \\
\hline 57.275 & 1.6072 & 1.6112 & 0.160 & 16 & 12 & 0.6 & 0.87 \\
\hline
\end{tabular}




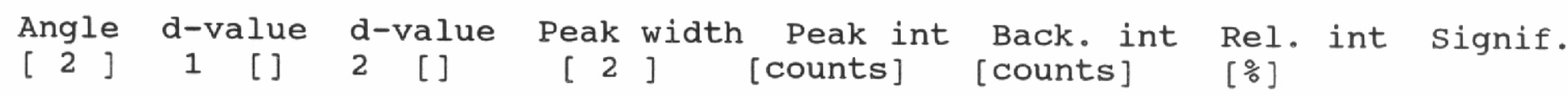

$\begin{array}{llllr}58.685 & 1.5719 & 1.5758 & 0.240 & 6 \\ 60.025 & 1.5400 & 1.5438 & 0.120 & 339 \\ 60.225 & 1.5354 & 1.5392 & 0.100 & 132 \\ 64.080 & 1.4520 & 1.4556 & 0.160 & 42 \\ 65.895 & 1.4163 & 1.4198 & 0.240 & 12 \\ 67.780 & 1.3815 & 1.3849 & 0.120 & 156 \\ 68.220 & 1.3736 & 1.3770 & 0.100 & 139 \\ 68.380 & 1.3708 & 1.3742 & 0.120 & 225 \\ 68.625 & 1.3665 & 1.3699 & 0.100 & 88 \\ 73.540 & 1.2868 & 1.2900 & 0.100 & 81 \\ 73.760 & 1.2835 & 1.2867 & 0.080 & 44 \\ 75.710 & 1.2552 & 1.2583 & 0.120 & 67 \\ 75.920 & 1.2523 & 1.2554 & 0.100 & 41 \\ 77.705 & 1.2279 & 1.2309 & 0.080 & 44\end{array}$

12
13
13
10
10
11
11
11
11
10
10
9
9
9

0.2
12.1
4.7
1.5
0.4
5.6
5.0
8.1
3.2
2.9
1.6
2.4
1.5
1.6

1.01

4.75

1.66

1.42

1.59

4.20

1.16

3.05

88

81

64

41

1.45

2.37

0.92

1.67

0.79

1.11 
Sample identification: PCC-CLAUDIA-S19C

Data measured at: 22-Jul-1998 15:51:00

\author{
Diffractometer type: PW1710 BASED \\ Tube anode: $\mathrm{Cu}$ \\ Generator tension $[\mathrm{kV}]: 40$ \\ Generator current [mA]: 40 \\ Wavelength Alpha1 []: 1.54060 \\ Wavelength Alpha2 []: 1.54439 \\ Intensity ratio (alpha2/alpha1): 0.500 \\ Divergence slit: 1 \\ Receiving slit: 0.2 \\ Spinner: ON \\ Monochromator used: YES

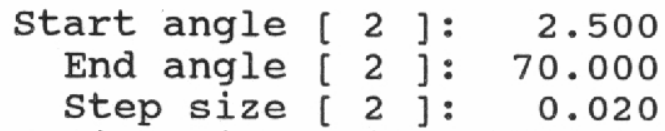 \\ Maximum intensity: 3375.610 \\ Time per step [s]: 1.000 \\ Type of scan: STEP
}
Minimum peak tip width: 0.05
Maximum peak tip width: 1.00
Peak base width: 2.00
Minimum significance: 0.75
Number of peaks: $\quad 35$

\begin{tabular}{|c|c|c|c|c|c|c|c|}
\hline $\begin{array}{l}\text { Angle } \\
{\left[\begin{array}{ll}2 & 2\end{array}\right]}\end{array}$ & $\begin{array}{c}\text { d-value } \\
1\end{array}$ & $\begin{array}{l}\text { d-value } \\
2\end{array}$ & $\begin{array}{l}\text { Peak widtr } \\
{\left[\begin{array}{ll}2 & ]\end{array}\right.}\end{array}$ & $\begin{array}{c}\text { Peak int } \\
\text { [counts] }\end{array}$ & $\begin{array}{l}\text { Back. int } \\
\text { [counts] }\end{array}$ & $\begin{array}{l}\text { Rel. int } \\
{[\%]}\end{array}$ & Signif. \\
\hline 8.815 & 10.0235 & 10.0481 & 0.120 & 12 & 18 & 0.4 & 1.06 \\
\hline 3.550 & 6.5296 & 6.5457 & 0.480 & -4 & -11 & 0.1 & 1.08 \\
\hline 3.605 & 4.7653 & 4.7770 & 0.160 & 16 & 10 & 0.5 & 0.75 \\
\hline .875 & 4.2520 & 4.2624 & 0.160 & 807 & --11 & 23.9 & 17.41 \\
\hline .080 & 3.8505 & 3.8600 & 0.240 & $\ldots 14$ & 12 & $\begin{array}{r}-0.4 \\
\end{array}$ & 0.87 \\
\hline 4.860 & 3.5787 & 3.5875 & 0.240 & 17 & $=12$ & $\ldots-0.5$ & 1.49 \\
\hline 5.550 & 3.4836 & 3.4922 & 0.240 & $\cdots 29$ & $\ldots 13$ & 0.9 & 1.39 \\
\hline 6.670 & 3.3398 & 3.3480 & 0.160 & 3376 & 13 & 100.0 & 37.49 \\
\hline 27.540 & 3.2362 & 3.2442 & 0.120 & 85 & 13 & -2.5 & 1.59 \\
\hline 29.405 & 3.0351 & 3.0425 & 0.080 & 144 & -14 & -4.3 & 0.77 \\
\hline 0.865 & 2.8947 & 2.9019 & 0.160 & -23 & 14 & -0.7 & 1.08 \\
\hline 2.765 & 2.7311 & 2.7378 & 0.320 & 26 & $\cdots-15$ & $\ldots-0.8$ & 0.90 \\
\hline 35.995 & 2.4931 & 2.4992 & 0.240 & 17 & -18 & 0.5 & 0.95 \\
\hline 36.535 & 2.4575 & 2.4635 & 0.100 & 282 & 18 & $\ldots-8.4$ & 3.12 \\
\hline 37.810 & 2.3775 & 2.3833 & 0.280 & -16 & $\ldots 17$ & $\ldots 0.5$ & 1.75 \\
\hline 39.500 & 2.2796 & 2.2852 & 0.080 & -204 & $\ldots 16$ & 6.1 & 1.43 \\
\hline 40.305 & 2.2359 & 2.2414 & 0.080 & 125 & $\ldots 16$ & $\ldots-3.7$ & 1.38 \\
\hline 42.480 & 2.1263 & 2.1315 & 0.160 & 199 & -15 & $-\quad 5.9$ & 5.85 \\
\hline 43.125 & 2.0960 & 2.1011 & 0.320 & 19 & $\ldots-14$ & $\ldots-0.6$ & 0.99 \\
\hline$\$ 5.720$ & 1.9829 & 1.9877 & 0.080 & 166 & $\ldots-14$ & $-\quad 4.9$ & 1.55 \\
\hline .825 & 1.9786 & 1.9834 & 0.080 & 190 & $\ldots 14$ & $\ldots-5.6$ & 1.49 \\
\hline & 1.9128 & 1.9175 & 0.480 & 21 & 13 & $-\quad 0.6$ & 2.01 \\
\hline 8.640 & 1.8704 & 1.8750 & 0.320 & 20 & 13 & 0.6 & 1.43 \\
\hline
\end{tabular}


Angle d-value d-value Peak width Peak int Back. int Rel. int signif.

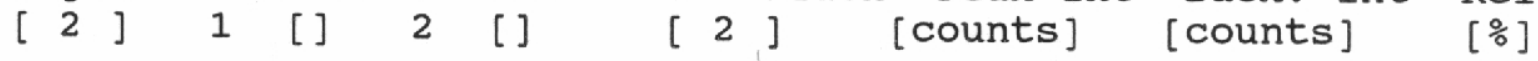

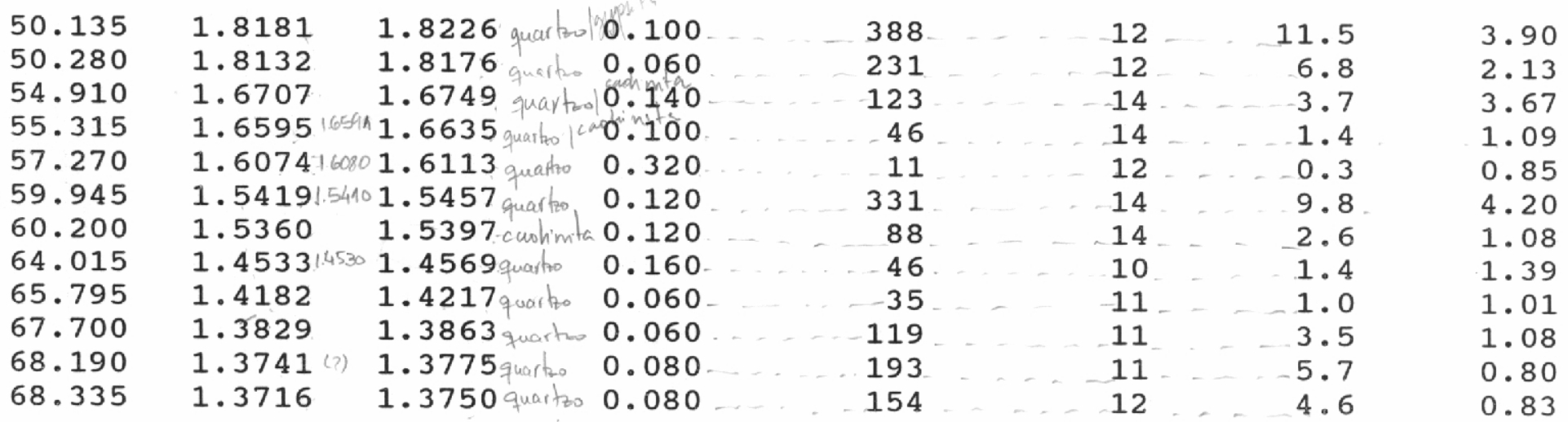


Sample identification: PCC-CLAUDIA-S19X

Data measured at: 12-Aug-1998 3:54:00

\author{
Diffractometer type: PW1710 BASED \\ Tube anode: $\mathrm{Cu}$ \\ Generator tension $[\mathrm{kV}]: 40$ \\ Generator current [mA] : 50 \\ Wavelength Alpha1 []: 1.54060 \\ Wavelength Alpha2 []: 1.54439 \\ Intensity ratio (alpha2/alpha1): 0.500 \\ Divergence slit: $1 / 2$ \\ Receiving slit: 0.2 \\ Spinner: ON \\ Monochromator used: YES \\ Start angle [ 2 ] : 2.500 \\ End angle [ 2 ]: 80.000 \\ Step size [ 2 ]: 0.020 \\ Maximum intensity: 1672.810 \\ Time per step [s]: 1.000 \\ Type of scan: STEP
}
Minimum peak tip width: 0.05
Maximum peak tip width: 1.00
Peak base width: 2.00
Minimum significance: 0.75
Number of peaks: 40

Angle d-value d-value Peak width Peak int Back. int Rel. int Signif.

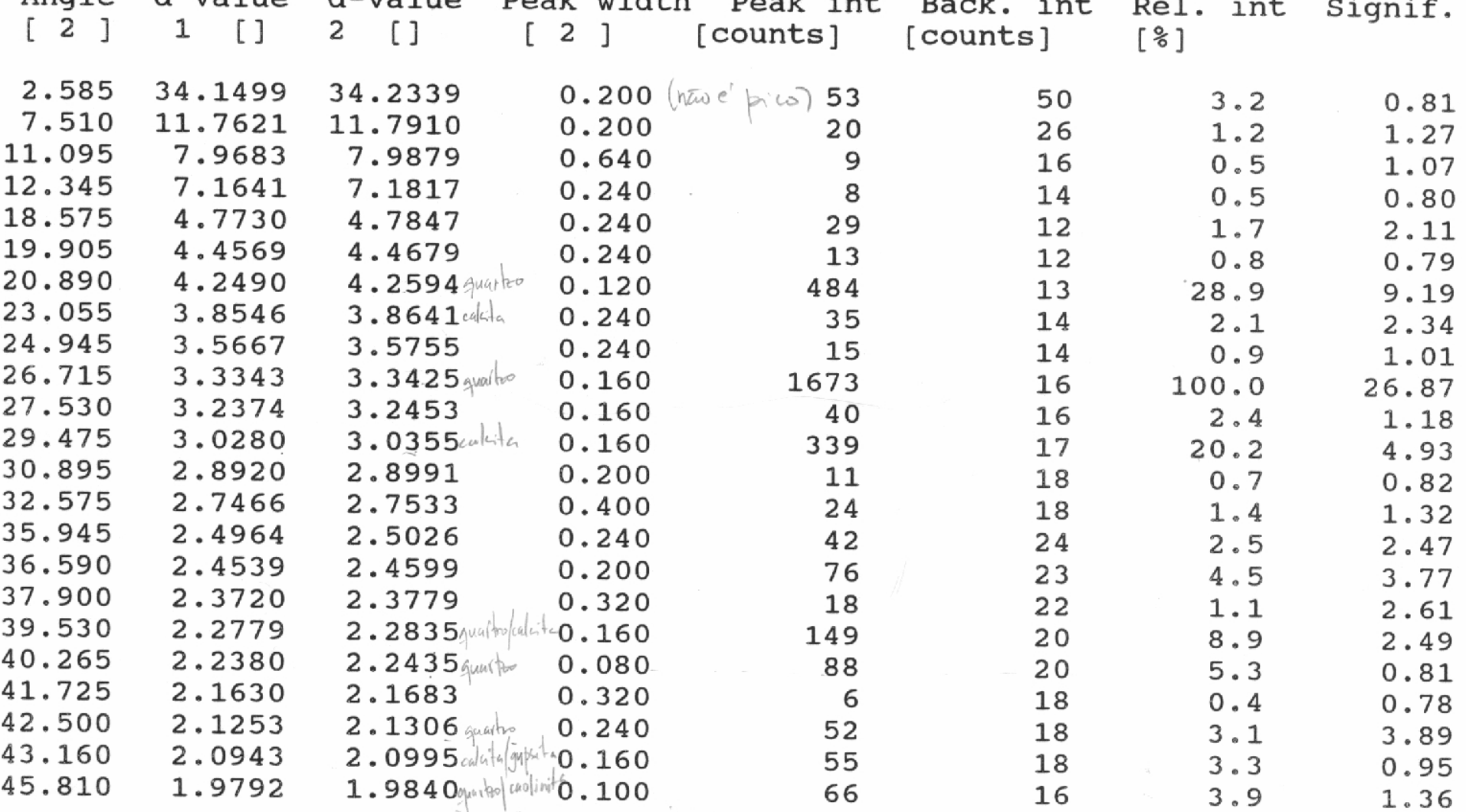


Angle d-value d-value Peak width Peak int Back. int Rel. int Signif.

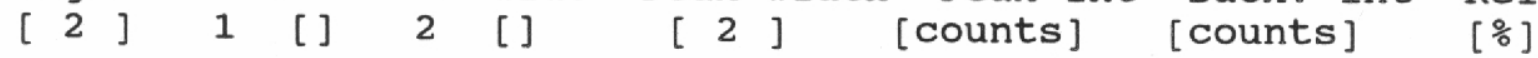

\begin{tabular}{|c|c|c|c|c|c|c|c|}
\hline 47.545 & 1.9109 & 1.9156 calkital & 0.280 & 53 & 15 & 3.2 & 3.09 \\
\hline 48.525 & 1.8746 & 1.8792 & 0.160 & 58 & 15 & 3.5 & 1.42 \\
\hline 50.130 & 1.8183 & 1.8227 punttas gy & 0.140 & 132 & 15 & 7.9 & 3.12 \\
\hline 53.500 & 1.7114 & 1.7156 & 0.240 & 10 & 13 & 0.6 & 1.16 \\
\hline 54.835 & 1.6729 & 1.6770 & 0.080 & 42 & 13 & 2.5 & 0.76 \\
\hline 55.355 & 1.6584 & 1.6624 & 0.120 & 27 & 13 & 1.6 & 1.41 \\
\hline 57.350 & 1.6053 & 1.6093 & 0.320 & 20 & 14 & 1.2 & 1.40 \\
\hline 60.005 & 1.5405 & 1.5443 quartzo & 0.100 & 256 & 17 & 15.3 & 3.48 \\
\hline 60.180 & 1.5364 & 1.5402 cartinit & 0.080 & 135 & 18 & 8.0 & 2.09 \\
\hline 64.025 & 1.4531 & 1.4567 & 0.200 & 17 & 14 & 1.0 & 1.19 \\
\hline 65.810 & 1.4180 & 1.4214 & 0.480 & 9 & 12 & 0.5 & 1.66 \\
\hline 67.745 & 1.3821 & 1.3855 guart too & 0.100 & 108 & 12 & 6.5 & 2.93 \\
\hline 68.320 & 1.3718 & 1.3752 quartio & 0.120 & 74 & 12 & 4.4 & 1.91 \\
\hline 73.530 & 1.2870 & 1.2901 & 0.320 & 20 & 11 & 1.2 & 1.70 \\
\hline 75.685 & 1.2556 & 1.2587 & 0.080 & 35 & 10 & $2 \cdot 1$ & 0.85 \\
\hline 77.775 & 1.2270 & 1.2300 & 0.320 & 7 & 10 & 0.4 & 0.88 \\
\hline 79.880 & 1.1999 & 1.2028 & 0.060 & 38 & 9 & $2 \cdot 3$ & 0.89 \\
\hline
\end{tabular}




\section{REFERÊNCIAS BIBLIOGRÁFICAS}

ALVES, M. R. P.; DEMATTÊ, M. E. S. P. Palmeiras: características botânicas e evolução. São Paulo, Fundação Cargill, 1987.

AMERICAN SOCIETY FOR TESTING AND MATERIALS. Standard test method for examination and analysis of hardened mansory mortar - ASTM C 1324/96. Philadelphia.1996.

ÁNGEL, M. C.; MARTINEZ, B.; PRENDES, N.; RODRIGUES, F. Evaluación por tratamiento digital de imágenes Del deterioro de monumentos: metodología. Materiales de Construcción, v. 45, n. 240, p.37-46, oct./nov./dic., 1995.

ANTELLINI, S. Gli stucchi ed i dipinti in Roma delle volte delle cappelle torres e ruissi in Santa Caterina de' Funari e della loggia detta del "Primaticcio" in palazzo di Firenze. In: SUPERFICI DELL' ARCHITETTURA: LE FINITURE. Bressanone, 1990. Atti. Bressanone, Università di Padova, Università di Venezia, IUAV, Politecnico di Milano, Università di Napoli, 1990, p. 139-49.

ASKAR, J.A.Reconstrução e imitação como alternativas da conservação. Caderno de Arquitetura e Urbanismo, n. 4, p. 7-20, maio,1996.

ASSOCIAÇÃO BRASILEIRA DE NORMAS TÉCNICAS. Agregados: determinação da composição granulométrica. Método de ensaio - NBR 7217. Rio de Janeiro, 1987.

ASSOCIAÇÃO BRASILEIRA DE NORMAS TÉCNICAS. Revestimentos de paredes e tetos de argamassas inorgânicas: determinação da resistência de aderência à tração. Método de ensaio - NBR 13528. Rio de Janeiro. 1995.

ASSOCIAÇÃO BRASILEIRA DE NORMAS TÉCNICAS. Revestimentos de paredes e tetos de argamassas inorgânicas: especificação - NBR 13749. Rio de Janeiro. 1996 
ASSOCIAÇÃO BRASILEIRA DE NORMAS TÉCNICAS. Argamassa colante industrializada para assentamento de placas cerâmicas: execução de substrato-padrão e aplicação de argamassa para ensaios - NBR 14082. Rio de Janeiro, 1998.

AZEREDO, H. A. O edifício e seu acabamento: prática de construção civil. São Paulo, Edgard Blücher, 1988.

BARROS, J. A. N. D. E. Cartas Patrimoniais. Brasília, IPHAN, 1995.

BLANCO-VARElA, M. T.; PUERTAS, F.; PALOMO, A. Los revocos de Medina Azahara. Parte I: caracterización Del material y procesos de alteración. Materiales de Construcción, v. 47, n.245, p. 29-43, enero/febrero/marzo,1997.

BOCCHINO, F. Problemi di conservazione dgli stucchi napoletani del '700. In: SUPERFICI DELL' ARCHITETTURA: LE FINITURE. Bressanone, 1990. Atti. Bressanone, Università di Padova, Università di Venezia, IUAV, Politecnico di Milano, Università di Napoli, 1990, p. 105-18.

BORGES, A. C. Práticas das Pequenas Construções. São Paulo, Edgard Blücher, 1972.

BRANDI, C. Teoría de la restauración. Madrid, Alianza Editorial, 1995.

BRISTISH STANDARD INSTITUTION. Guide to the principles of the conservation of historic buildings - BS 7913. London, 1998-a.

BRISTISH STANDARD INSTITUTION. Methods of testing mortars, screeds and plasters - BS 4551. London, 1998-b.

CAMPITELLI, A. Il tempio di Esculapio a villa Borghese a Roma - Indagine sugli stucchi e sui colori. In: SUPERFICI DELL' ARCHITETTURA: LE FINITURE. Bressanone, 1990. Atti. Bressanone, Università di Padova, Università di Venezia, IUAV, Politecnico di Milano, Università di Napoli, 1990, p. 119-25.

CARASEK, H.; CASCUDO, O. Técnicas auxiliares do diagnóstico de manifestações patológicas e na restauração das argamassas de revestimento. In: CONGRESSO ÍBERO-AMERICANO DE PATOLOGIA DAS CONSTRUÇÕES, 4, Porto Alegre, 1997.Anais. Porto Alegre, UFRGS/CPGEC, 1997. p. 615-21. 
CAVANI, G. De R.; QUARCIONI, V. A.; NASCIMENTO, C. B. Formulação e avaliação de argamassa de revestimento para restauração de fachada - estudo de caso. In: SIMPÓSIO BRASILEIRO DE TECNOLOGIA DAS ARGAMASSAS, 3, Vitória,1999. Anais. Espírito Santo, PPGEC/ANTAC, 1999, p. 661-74.

CHAGAS, M. Entre mortos e feridos - A construção do discurso preservacionista em dois intelectuais do patrimônio. Revista semestral do Mestrado em Artes Visuais, v. 6, n. 10, p.87-99. nov., 1995.

CINCOTTO, M. A. Estudo da composição química da cal hidratada produzida no estado de São Paulo. São Paulo, 1977. Dissertação (Mestrado) - Escola Politécnica, Universidade de São Paulo.

DE TOLEDO, B. L. 1993. Vila Penteado - Carlos Ekman: um arquiteto sueco no Brasil. São Paulo: FAU/USP. 22 p. (Boletim Técnico, 09).

DEMANET, A. Cours de construction. Paris, Librairie Scientifique, Industrielle et Agricole de E. Lacroix, 1871.

FRIZOT, M. L' analyse des mortiers antiques: problemes et resultats. In: MORTARS, CEMENTS AND GROUTS USED IN THE CONSERVATION OF HISTORIC BUILDING, Roma, 1981. Proceedings. Roma, ICCROM, 1981. p. 331 - 40,

GLEIZE, P. NAPPI, S., SILVA,D. A. Caracterização de revestimentos de argamassa do Palácio Cruz e Souza de Florianópolis - SC In: SIMPÓSIO BRASILEIRO DE TECNOLOGIA DAS ARGAMASSAS, 3, Vitória,1999. Anais. Espírito Santo, PPGEC/ANTAC, 1999, p. 645-60.

GOMES, A M.; CARVALHO JR., A N. Estudo de argamassas de revestimento ao microscópio eletrônico de varredura. In: SIMPÓSIO BRASILEIRO DE TECNOLOGIA DAS ARGAMASSAS, 2, Salvador, 1997, Anais. Bahia, CETA/UFBA/ANTAC, 1997. p. 363-72.

GRANDE ENCIClOPÉDIA LAROUSSE CULTURAL. São Paulo, Nova Cultural, 1998.

GUIMARÃES, J. E. P. Terminologia de calcários-dolomitos e da cal. São Paulo, ABPC, 1989. 
GULEÇ, A.; TULUN, T. Physico-chemical and petrographical studies of old mortars and plaster of Anatolia. Cement and Concrete Research, v. 27, p. 227 - 34, Feb., 1997.

GUTIERREZ-SOLANA, F.; JAUREGUI, M. Análisis de morteros medievales de dos castillos de Cantabria/España. Materiales de Construcción, v. 39, n. 213, p. 37 45, enero/febrero/marzo, 1989.

HOMEM, M. C. N. 1993. Vila Penteado - Carlos Ekman, um inovador na arquitetura paulista. São Paulo: FAU/USP. 24 p. (Boletim Técnico, 10).

INTERNATIONAL FEDERATITION FOR HOUSING AND PLANNING; FEDERATION INTERNATIONALE POUR L'HABITATION L'URBANISME ET L'AMENAGEMENT DES TERRITOIRES; INTERNATIONALER VERBAND FUR WOHNUNGSWESEN STADTEBAU UND RAUMORDNUNG. Concours International FIHUAT pour etudiants en architecture, urbanisme et amenagement regional: l'integration de l'ancien et du moderne dans les quartiers historiques. Folder. Séville, 1987.

JOHN, V. M.; SATO, N. M. N.; BONIN, L. C. Proposta de terminologia para o temaÇ durabilidade no ambiente construído. In: WORKSHOP SOBRE DURABILIDADE DAS CONSTRUÇÕES. São José dos Campos, 2001. Anais. São Paulo, Instituto Tecnológico de Aeronáutica, 2001. p. 105-11.

KANAN, M. I. C.; An analytical study of earth and lime based building materials in the Blumenau Region Southern Brazil. Bournemouth,1995. Tese (PhD), Bournemouth University, Inglaterra.

KATINSKY, J. R. 1993. Vila Penteado - Arquitetos e engenheiros estrangeiros em São Paulo na virada do século. São Paulo: FAU/USP. 31 p. (Boletim Técnico, 04).

LAGUNES, M. M. S. Conservazione degli intonaci tradizionali in Messico. In: SUPERFICI DELL' ARCHITETTURA: LE FINITURE. Bressanone, 1990. Atti. Bressanone, Università di Padova, Università di Venezia, IUAV, Politecnico di Milano, Università di Napoli, 1990, p. 97-101.

LEITÃO, L. A. Curso elementar de construção. Lisboa, Imprensa Nacional de Lisboa, 1896. 
LICHTENSTEIN, N. B. Patologia das construções. São Paulo: EPUSP. (Boletim Técnico 06).

LONDON, D. Plaster Renaissance. Architecture, v. 69, n. 21, p.87-91, jan., 1992.

LUXÁN, M. P.; DORREGO, F. Ancient XVI century mortar from Dominican Republic: its characteristics, microstrucutre and additives. Cement and Concrete Research, v. 26, n. 6, p. 841-9, jun, 1996.

LUXÁN, M. P.; DORREGO, F.; LABORDE, A. Ancient gypsum mortars from St. Engracia, Zaragoza, Spain: characterization, identification of additives and treatments. Cement and Concrete Research, v. 25, n. 8, p. 1755-65, dec., 1995.

MACEDO, S. S. 1993. Vila Penteado - A Vila Penteado significado paisagístico. São Paulo: FAU/USP. 23 p. (Boletim Técnico, 08).

MALINOWSKI, R.; Ancient mortars and concretes: durability aspects. In: MORTARS, CEMENTS AND GROUTS USED IN THE CONSERVATION OF HISTORIC BUILDING, Roma, 1981. Proceedings. Roma, ICCROM, 1981. p. 341 - 30.

MARTINET, G.; DELOYE, F. X.; GOLVIN, J.C. Caractérisation des mortiers pharaoniques du Temple d'Amon à Karnak. Bulletin des Laboratoires des Ponts et Chaussées, n. 181, p. 39 - 45, sept./oct., 1992.

MARTINET, G.; DELOYE, F. X.; LE ROUX, A. Natures et altérations des mortiers de restauration du Temple d'Amon à Karnak. Bulletin des Laboratoires des Ponts et Chaussées, n. 182, p. $21-6$, nov./déc., 1992.

MARTINET, G.; MARTINEAU, F.; LE ROUX, A. Mise au point et optimisations de mortiers pour la restauration des monuments de HAUTE-Égypte: actualisations des résultats. Bulletin des Laboratoires des Ponts et Chaussées, n. 190, p. 65 - 74, mars/avr., 1994.

MARTINEZ, M. C. A.; PRENDES, N.; RODRÍGUEZ, F. Evaluación por tratamiento digital de imágenes del deterioro de monumentos. In: Materiales de Construcción, v. 45, n. 240 , p. 35 - 46, oct./nov./dic., 1987.

MARTINEZ-RAMIREZ, S.; PUERTAS MAROTO, F.; BLANCO-VARELA, M. T. Morteros de reparación basados em cal: ensayos de envejecimiento acelerado. Materiales de Construcción, v. 45, n.238, p. 35 - 45, abr./mai./jun., 1995. 
MERRITT, F. S.; RICKETTS, J. T.; Building design and construction handbook. McGraw-Hill, Inc., EUA, 1994.

MORICONI, G. Degrado da solfato degli intonaci delle murature: diagnosi e materiali per il restauro. In: SUPERFICI DELL' ARCHITETTURA: LE FINITURE. Bressanone, 1990. Atti. Bressanone, Università di Padova, Università di Venezia, IUAV, Politecnico di Milano, Università di Napoli, 1990, p. 159-66.

NASCIMENTO, C. B.; QUARCIONI, V. A.; OLIVEIRA, M. C. B. de; GOULART, E. P.; THOMAZ, O.; MANHOLETTI, J.L. A.; Caracterização da argamassa do forro visando restauro da edificação histórica Vila Penteado. In: V CONGRESSO IBEROAMERICANO DE PATOLOGIA DAS CONSTRUÇÕES, 5., Montevidéo, 1999. Anais. Montevidéo, SAGA, 1999. p. 1437-45

NASCIMENTO, C. B.; MONTEIRO, M. B. B.; CINCOTTO, M. A.; OLIVEIRA, M. C. B.; QUARCIONI, V. A.; CHOTOLI, F. F. Influência do ataque fúngico de ripas de juçara em argamassa de estuque - estudo de caso. In: SIMPÓSIO BRASILEIRO DE TECNOLOGIA DAS ARGAMASSAS, 4., Brasília, 2001. Anais. Distrito Federal, PECC/ANTAC, 2001, p. 533-46.

OLIVEIRA M. C. B.; NASCIMENTO C. B.; CINCOTTO, M. A.; Microestrutura de Argamassas Endurecidas: Uma Contribuição da Petrografia. In: V CONGRESSO IBEROAMERICANO DE PATOLOGIA DAS CONSTRUÇÕES, 5., Montevidéo, 1999. Anais. Montevidéo, SAGA, 1999. p. 227-34.

OLIVEIRA, M. M. Um sistema para consolidação de estuque no Palácio Rio Branco- Salvador, Universidade Federal da Bahia, 1983.

ORNSTEIN, S. W. 1993. Vila Penteado - A tecnologia de recuperação do telhado do edifício Vila Penteado da Faculdade de Arquitetura e Urbanismo. São Paulo: FAU/USP. 23 p. (Boletim Técnico, 03).

PADILHA, A. F.; AMBROZIO FILHO, F. Técnicas de análise microestrutural. São Paulo, Hemus, 1985.

PETERSON, S. Lime water consolidation. In: MORTARS, CEMENTS AND GROUTS USED IN THE CONSERVATION OF HISTORIC BUILDING, Roma, 1981. Proceedings. Roma, ICCROM, 1981. p. $53-61$. 
PIANA, M.; ARMANI, E. A research programme on the plaster of historical buildings in Venice. In: MORTARS, CEMENTS AND GROUTS USED IN THE CONSERVATION OF HISTORIC BUILDING, Roma, 1981. Proceedings. Roma, ICCROM, 1981. p. 385 - 400.

PRUD'HOMME, L. Cours pratique de construction. Paris, Librairie Polytechnique, Baudry et $C^{\text {ie }}, 1895$.

PUERTAS, F.; BLANCO-VARELA, M. T.; PALOMO, A. Stucos y hormigones romanos de la ciudad de Baelo Claudia (Cádiz): caracterización y causas de deterioro. Materiales de Construcción, v. 39, n. 213, p. 37 - 45, enero/febrero/marzo, 1989.

QUARCIONI, V. A. et al.; Reconstituição de Traço de Argamassas: Aplicações e Limitações da Análise Química. In: . In: SIMPÓSIO BRASILEIRO DE TECNOLOGIA DAS ARGAMASSAS, 2., Salvador, 1997. Anais. Bahia, CETA/UFBA/ANTAC, 1997, p. 412-24.

QUARCIONI, V. A. Reconstituição de traço de argamassas: atualização do método IPT. São Paulo, 1998. Dissertação (Mestrado) - Escola Politécnica, Universidade de São Paulo.

QUARCIONI, V. A.; CINCOTTO, M. A.; CHOTOLI, F. F. (a) Caracterização da composição de argamassas de assentamento e de revestimento II: Diretrizes para Normalização. In: SIMPÓSIO BRASILEIRO DE TECNOLOGIA DAS ARGAMASSAS, 3, Vitória,1999. Anais. Espírito Santo, PPGEC/ANTAC, 1999, p. 753-68.

QUARCIONI, V. A.; CHOTOLI, F. F.; OTA, S. (b) Aplicação de método para identificação de aditivo em argamassa de cimento Portland. In: SIMPÓSIO BRASILEIRO DE TECNOLOGIA DAS ARGAMASSAS, 3, Vitória,1999. Anais. Espírito Santo, PPGEC/ANTAC, 1999, p. 45-58.

RAINVILLE, C. O vinhola brasileiro. Rio de Janeiro, Eduardo \& Henrique Laemmert, 1880.

RAMÉE, D. L' architecture et la construction. Paris, Librairie de Firmin-Didot Frères, fils et $\mathrm{C}^{\mathrm{ie}}, 1875$. 
REED, J. S. Principles of ceramics processing. New York, John Willey \& Sons, 1995.

REIS FILHO, N. G. Proposta para um programa integrado de preservação e restauração do patrimônio cultural da USP. São Paulo, outubro, 1987.

REITER, O. P. Vila Penteado - Ambiente arquitetônico sueco na época do Arquiteto Carlos Ekman. São Paulo: FAU/USP. 17 p. (Boletim Técnico, 02).

REYNAUD, M. L. Traité d' architecture, I ${ }^{\text {ière }}$ Partie. Paris, Librarie des Corps Impériaux des Ponts et Chaussées et de Mines, 1867.

RIBEIRO, R. T. M. Recuperação de obras históricas - Restauração da Casa FrançaBrasil (RJ). In: V CONGRESSO IBEROAMERICANO DE PATOLOGIA DAS CONSTRUÇÕES, 4., Porto Alegre, 1997. Anais. Porto Alegre, UFRGS/CPGEC, 1997. p. 615-621.

ROCHA FILHO, G. N. O teto do casarão ocupado pela FAU na rua Maranhão está desabando. Jornal da Tarde. São Paulo, 08 de julho,1994.

ROSSI-DORIA, P. R. Mortars for restoration: basic requirements and quality control. Matériaux et Constructions, v. 19, n. 114, p. 445 - 8, nov./dec., 1986.

ROSSI-DORIA, P. R. Report on the rilem. Workshop Ancient Mortars and Mortars for Restoration. 1988. Matériaux et Constructions, v. 23, n. 135, p. 235 - 8, may, 1990.

SÁIZ-JIMÉNEZ, C.; ARIÑO, X. Colonización biológica y deterioro de morteros por organismos fotótrofos. In: Materiales de Construcción, v. 45, n. 240, p. 5 - 16, oct./nov./dic., 1995.

SARKAR, S. L. Microstructural investigation of renaissance mortar from Montreal, Québec, Canada. Cement and Concrete Research, vol. 22, p. 1011 - 18, nov., 1992.

SARKAR, S. L.; BHADRA, A. K.; MANDAL, P. K. Investigation of mortar and stone deterioration in the Victoria Memorial, Calcutta. Materials and Structures, vol. 27, p. 548 - 556, nov., 1994. 
SATO, N. M. N. Análise da porosidade e de propriedades de transporte de massa em concretos. São Paulo, 1999. Tese (Doutorado) - Escola Politécnica, Universidade de São Paulo.

SEGURADO, J. E. S. Acabamentos das construções. estuque, pinturas e etc. Lisboa, Livraria Bertrand, 1936.

SHIRAKAWA, M. A. Biodeterioração de argamassas por fungos: desenvolvimento de teste acelerado para avaliação da bio-receptividade. São Paulo, 1999. Tese (Doutorado) - Instituto de Ciências Biomédicas, Universidade de São Paulo.

SHIRAKAWA, M. A.; MONTEIRO, M. B. B.; SELMO, S. M. S.; CINCOTTO, M. A. Identificação de fungos em revestimentos de argamassa com bolor evidente. In: SIMPÓSIO BRASILEIRO DE TECNOLOGIA DAS ARGAMASSAS, 2., Goiânia,1995. Anais. Goiás, UFG/ANTAC, 1997, p. 402-10.

SILVA, M. R.; DELOYE, F. X. Dégradation biologique des bétons. Bulletin des Laboratoires des Ponts et Chaussées, n. 176, p. 87 - 91, nov./dec., 1991.

SIMÕES, J. R. L. 1993. Vila Penteado - Especificações técnicas das obras de preservação e restauro do edifício à rua Maranhão. São Paulo. FAU/USP. 48 p. (Boletim Técnico, 12).

STEWART, J.; MOORE, J.; Chemical techniques of historic mortar analysis. In: MORTARS, CEMENTS AND GROUTS USED IN THE CONSERVATION OF HISTORIC BUILDING, Roma, 1981. Proceedings. Roma, ICCROM, 1981. p. 298 -310 .

SZMRECSANYI, M. I. 1993. Vila Penteado - Cem anos de presença sueca no Brasil. São Paulo. FAU/USP. 24 p. (Boletim Técnico, 05).

TIRELLO, R. A. 1993. Vila Penteado -Prospecção e restauração das pinturas murais da Vila Penteado. São Paulo. FAU/USP. 28 p. (Boletim Técnico, 11).

UNIVERSidAde DE SÃO PAUlO, FAU. Exposição Vila Penteado. São Paulo, 1976.

VARGAS, M. et al. História da técnica e da tecnologia no Brasil. São Paulo, UNESP, 1994. 
YURGEL, M. 1993. Vila Penteado - Primeira geração de arquitetos formados pela FAUUSP. São Paulo. FAU/USP. 23 p. (Boletim Técnico, 06).

ZACHWATOWICZ, J. La protección de los monumentos históricos en la Polonia popular. Ed. Polonia, Varsóvia, 1956.

ZAMPIERI, V. A. Cimento Portland aditivado com pozolanas de argilas calcinadas: Fabricação, hidratação e desempenho mecânico. São Paulo, 1993. Tese (Doutorado). Instituto de Geociências, Universidade de São Paulo. 